\title{
MULTIPLE ION EXCHANGE COLUMN RUNS FOR CESIUM AND TECHNETIUM REMOVAL FROM AW-101 WASTE SAMPLE (U)
}

JULY 2003

SAVANNAH RIVER TECHNOLOGY CENTER

Westinghouse Savannah River Company Savannah River Site Aiken, SC 29808 
This document was prepared in conjunction with work accomplished under Contract No. DE-AC09-96SR18500 with the U. S. Department of Energy.

\section{DISCLAIMER}

This report was prepared as an account of work sponsored by an agency of the United States Government. Neither the United States Government nor any agency thereof, nor any of their employees, makes any warranty, express or implied, or assumes any legal liability or responsibility for the accuracy, completeness, or usefulness of any information, apparatus, product or process disclosed, or represents that its use would not infringe privately owned rights. Reference herein to any specific commercial product, process or service by trade name, trademark, manufacturer, or otherwise does not necessarily constitute or imply its endorsement, recommendation, or favoring by the United States Government or any agency thereof. The views and opinions of authors expressed herein do not necessarily state or reflect those of the United States Government or any agency thereof.

This report has been reproduced directly from the best available copy.

Available for sale to the public, in paper, from: U.S. Department of Commerce, National Technical Information Service, 5285 Port Royal Road, Springfield, VA 22161, phone: (800) 553-6847, fax: (703) 605-6900

email: orders@ntis.fedworld.gov

online ordering: http://www.ntis.gov/help/index.asp

Available electronically at http://www.osti.gov/bridge

Available for a processing fee to U.S. Department of Energy and its contractors, in paper, from: U.S. Department of Energy, Office of Scientific and Technical Information, P.O. Box 62, Oak Ridge, TN 37831-0062,

phone: (865)576-8401,

fax: (865)576-5728

email: $\underline{\text { reports@ adonis.osti.gov }}$ 
WSRC-TR-2003-00098, REVISION 0

SRT-RPP-2003-00026, REVISION 0

Key Words:

Hanford River Protection Project

Cesium, rhenium, technetium, SuperLig

Retention:

Permanent

Key WTP R\&T References:

Test Specification

TSP-W375-00-00030, Rev. 1

Test Plan

WSRC-TR-2001-00545, Rev. 1

SRT-RPP-2001-00207, Rev. 1

Test Exception

24590-WTP-TEF-RT-02-077

\title{
MULTIPLE ION EXCHANGE COLUMN RUNS FOR CESIUM AND TECHNETIUM REMOVAL FROM AW-101 WASTE SAMPLE (U)
}

\author{
Neguib M. Hassan \\ Kofi Adu-Wusu \\ Charles A. Nash
}

Issue Date: JULY 2003

Westinghouse Savannah River Company

Savannah River Site

Aiken, SC 29808

Prepared for the U.S. Department of Energy Under Contract Number DE-AC09-96SR18500

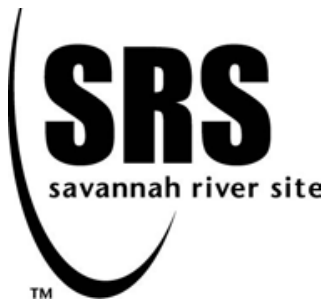


WSRC-TR-2003-00098, REVISION 0 SRT-RPP-2003-00026, REVISION 0

\section{TABLE OF CONTENTS}

LIST OF FIGURES iv

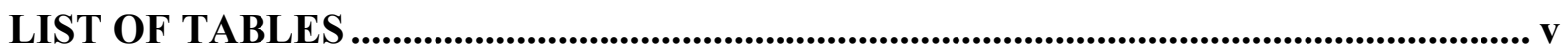

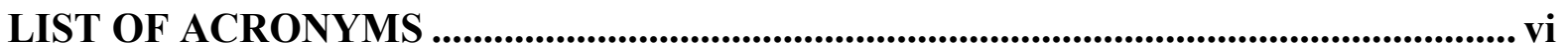

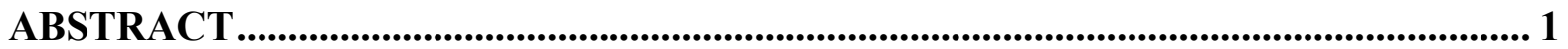

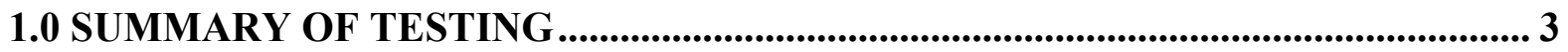

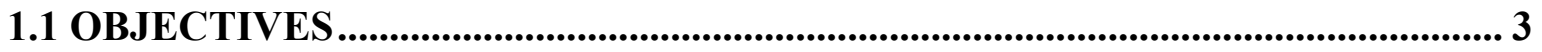

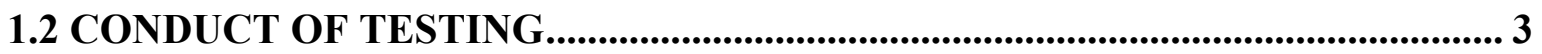

1.3 RESULTS AND PERFORMANCE AGAINST OBJECTIVES ............................... 4

1.4 QUALITY REQUIREMENTS.......................................................................5

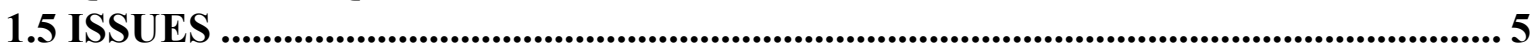

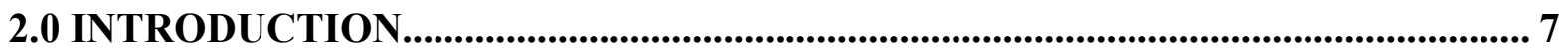

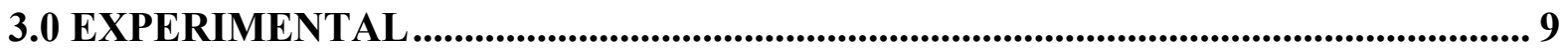

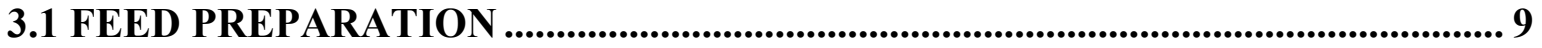

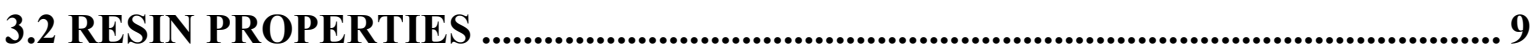

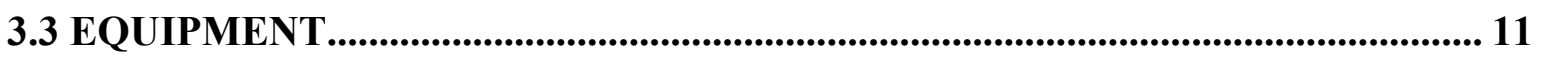

3.4 SAMPLING AND ANALYSIS............................................................................. 12

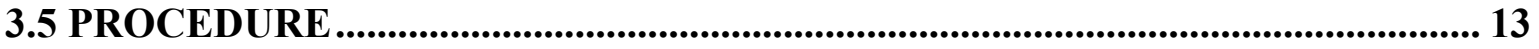

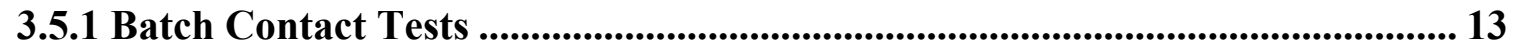

3.5.2 Simulant Column Tests....................................................................................... 14

3.5.3 Cesium Column Multi-Cycle Tests -Hot Cell............................................................ 16

3.5.4 Technetium Column Runs............................................................................... 18

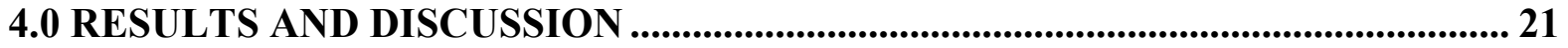

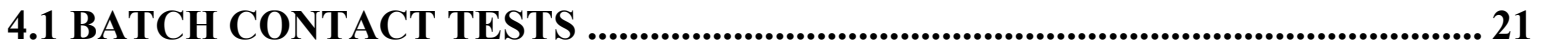

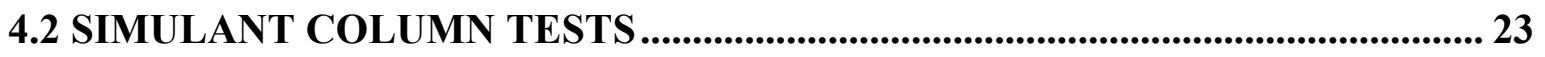

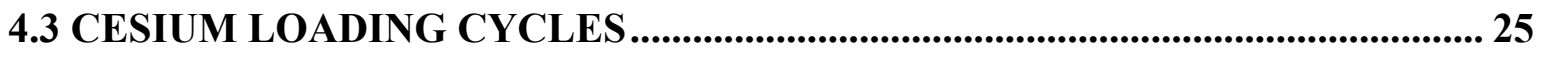

4.4 CESIUM ELUTION CYCLES ......................................................................... 34

4.5 TECHNETIUM LOADING CYCLES ...................................................................... 41

4.6 TECHNETIUM DISPLACEMENT AND ELUTION ........................................... 46

4.7 EFFLUENT COMPOSITE PRODUCTS ........................................................... 54

4.8 CESIUM ELUATE PRODUCTS ..................................................................... 54

4.9 TECHNETIUM ELUATE PRODUCTS .......................................................... 59

4.10 SPENT RESIN ANALYSIS ..........................................................................61

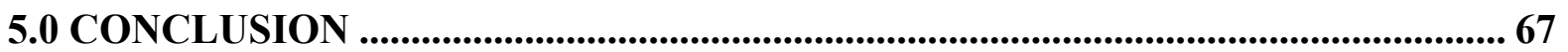

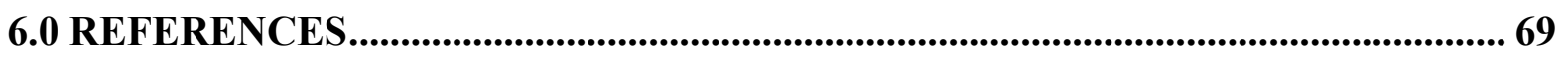

APPENDIX A - AW-101 FEED CONCENTRATIONS ................................................. 71

APPENDIX B - BATCH CONTACT DATA............................................................ 73

APPENDIX C - CESIUM LOADING AND ELUTION DATA .................................. 75

APPENDIX D - TECHNICIUM LOADING AND ELUTION DATA........................... 93

APPENDIX E - COMPOSITE PRODUCTS DATA ................................................ 113

APPENDIX F - DOSE RATE CALCULATION .................................................... 119 


\section{LIST OF FIGURES}

Figure 3-1. Photograph of Test Equipment in Operation Inside the Hot Cell

Figure 3-2. Photograph of Test Equipment in Operation Inside the Radiochemical Hood .. 19

Figure 4-1. Cs Breakthrough and Elution Curves - Simulant............................................... 23

Figure 4-2. Re Breakthrough and Elution Curves - Simulant.................................................. 24

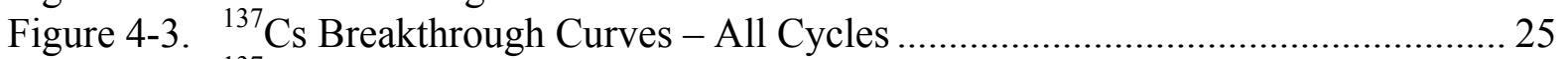

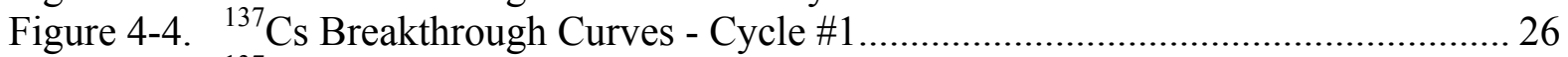

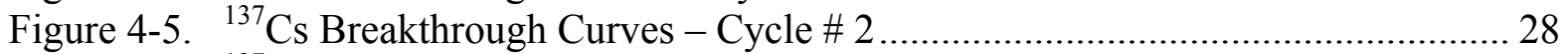

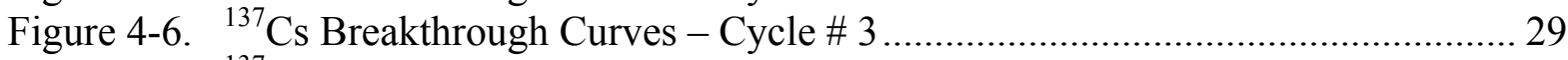

Figure 4-7. ${ }^{137}$ Cs Breakthrough Curves - Cycle \# 4 ....................................................... 30

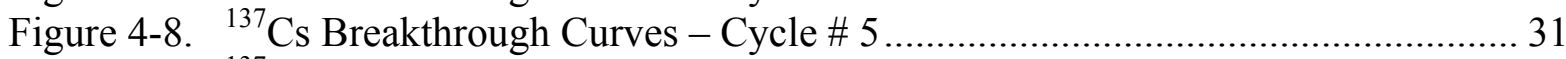

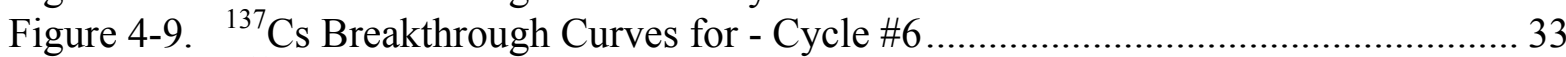

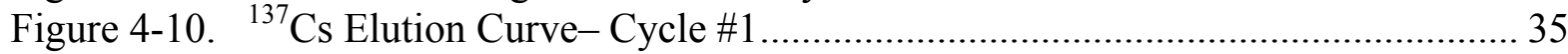

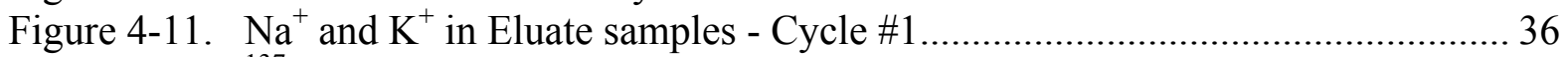

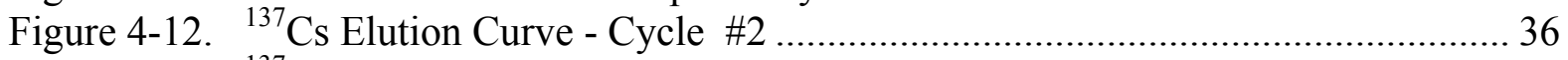

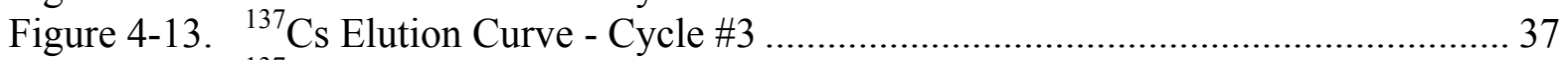

Figure 4-14. ${ }^{137} \mathrm{Cs}$ Elution Curve - Cycle \#4 .......................................................... 38

Figure 4-15. ${ }^{137}$ Cs Elution Curve - Cycle \#5 ………….................................................. 39

Figure 4-16. ${ }^{137} \mathrm{Cs}$ Elution Curve - Cycle \#6 …………................................................. 40

Figure 4-17. $\mathrm{pH}$ and $\mathrm{Na}^{+}$in Post-Elution rinse - Cycle \#6 …………................................. 40

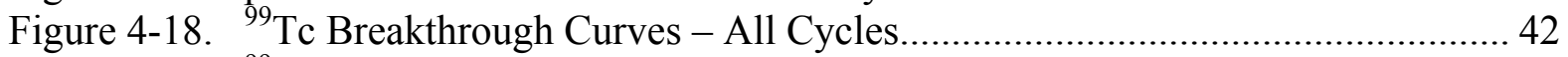

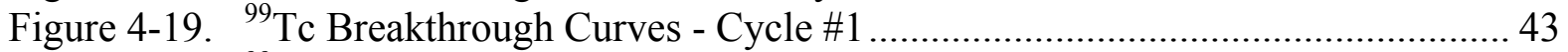

Figure 4-20. ${ }^{99}$ Tc Breakthrough Curves - Cycle \#2 …….................................................. 43

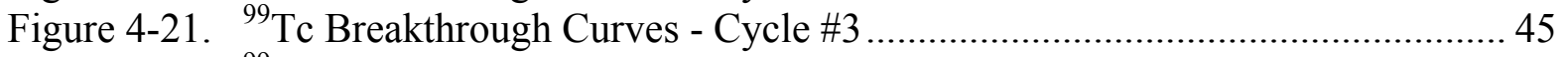

Figure 4-22. ${ }^{99} \mathrm{Tc}$ Breakthrough Curves - Cycle \#4 ……..................................................... 45

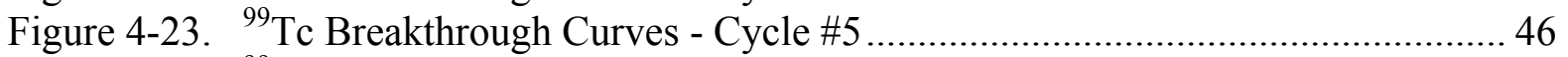

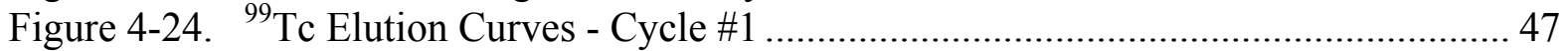

Figure 4-25. Feed Displacement and Elution - Cycle \#1 ................................................... 48

Figure 4-26. ${ }^{99}$ Tc Elution Curve - Cycle \# 2 ……….................................................... 48

Figure 4-27. Feed Displacement and Elution - Cycle \# 2 …….......................................... 49

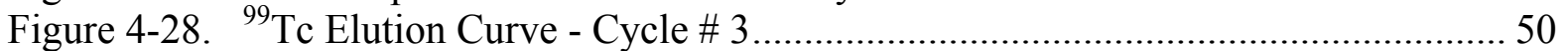

Figure 4-29. Feed Displacement and Elution - Cycle \# 3 ................................................... 51

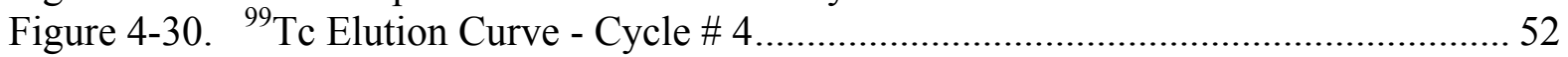

Figure 4-31. Feed Displacement and Elution - Cycle \# 4 ............................................... 52

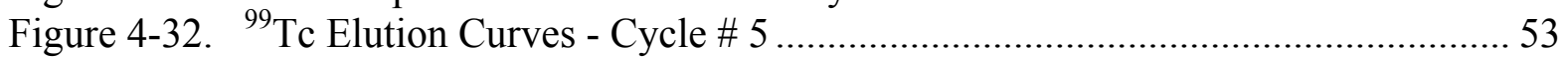

Figure 4-33. Feed Displacement and Elution - Cycle \# 5 .................................................. 53 


\section{LIST OF TABLES}

Table 3-1. Composition of AW-101 Feed Samples.......................................................... 10

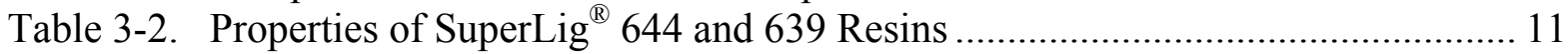

Table 3-3. A Summary of the Test Conditions ................................................................. 16

Table 4-1. $\mathrm{K}_{\mathrm{d}} \mathrm{S}$ for Cesium in AW-101 Actual Waste and Simulant Solutions ..................... 22

Table 4-2. $\mathrm{K}_{\mathrm{d}} \mathrm{S}$ for Technetium in AW-101 Actual Waste Sample.......................................... 22

Table 4-3. Summary of ${ }^{137} \mathrm{Cs}$ loading Performance (BV) .................................................... 26

Table 4-4. Summary of ${ }^{137}$ Cs Column Dose and Loading Capacity ...................................... 33

Table 4-5. Resin Bed Swelling and Shrinking History for Lead Column ............................. 34

Table 4-6. Statistical Summary of ${ }^{99} \mathrm{Tc}$ Lead Column Performance at $\mathrm{C} / \mathrm{Co}=0.1 \ldots \ldots \ldots \ldots . . .41$

Table 4-7. Composition of Effluent Composite Product ..................................................... 55

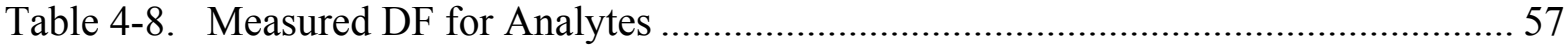

Table 4-9. Composition of Cesium Eluate Composite Products ……………………............5 57

Table 4-10. Composition of Technetium Eluate Composite Products .................................. 59

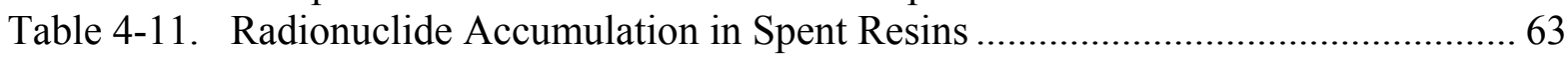

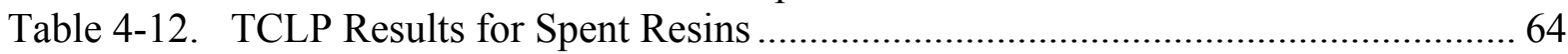

Table 4-13. ICP-AES Results of Spent Resin Dissolution Samples..................................... 65 


\section{LIST OF ACRONYMS}

$\begin{array}{ll}\text { AW-101 } & \text { Hanford Site Tank 241-AW-101 } \\ \text { ADS } & \text { Analytical Development Section } \\ \text { BV } & \text { Bed volume } \\ \text { Ce } & \text { Equilibrium concentration of a species } \\ \text { Co } & \text { Initial concentration of a species } \\ \text { C/Co } & \text { Metal concentration in the column effluent divided by the metal concentration } \\ & \text { in feed } \\ \text { DF } & \text { Decontamination factor } \\ \text { DI } & \text { De-ionized water } \\ \text { F-Factor } & \text { Mass of oven-dried resin divided by the mass of nitrogen-dried resin } \\ \text { GEA } & \text { Gamma energy analysis } \\ \text { HLC } & \text { High level cell } \\ \text { HLW } & \text { High level waste } \\ \text { IC } & \text { Ion chromatography } \\ \text { ICP-AES } & \text { Inductively coupled plasma - atomic emission spectroscopy } \\ \text { ICP-MS } & \text { Inductively coupled plasma - mass spectroscopy } \\ \text { ILC } & \text { Intermediate level cell } \\ \text { K } & \text { Equilibrium sorption distribution coefficient } \\ \text { LSC } & \text { Liquid scintillation counter } \\ \text { MRQ } & \text { Minimum reportable quantity } \\ \text { na } & \text { not applicable } \\ \text { NAA } & \text { Neutron activation analysis } \\ \text { nm } & \text { not measured } \\ \text { PNNL } & \text { Pacific Northwest National Laboratory } \\ \text { PSD } & \text { Particle size distribution } \\ \text { RCRA } & \text { Resource Conservation Recovery Act } \\ \text { RPP-WTP } & \text { River Protection Project - Waste Treatment Plant } \\ \text { RSD } & \text { Relative standard deviation } \\ \text { SRTC } & \text { Savannah River Technology Center } \\ \text { TAV } & \text { Total apparatus volume } \\ \text { TCLP } & \text { Toxicity Characteristic Leaching Procedure } \\ \text { TIC } & \text { Total inorganic carbon } \\ \text { TOC } & \text { Total organic carbon } \\ \text { TTA } & \text { Thenoyltrifluoroacetone } \\ & \end{array}$




\section{WSRC-TR-2003-00098, REVISION 0 SRT-RPP-2003-00026, REVISION 0}

\section{ABSTRACT}

The River Protection Project -Waste Treatment Plant (RPP-WTP) will be performing cesium $\left({ }^{137} \mathrm{Cs}\right)$ removal from Hanford tank waste supernatants using SuperLig ${ }^{\circledR} 644$ resin. This work also covers technetium $\left({ }^{99} \mathrm{Tc}\right)$ removal with SuperLig ${ }^{\circledR} 639$, though this is no longer in the flowsheet. These elutable resins will be used multiple times to process large volumes of radioactive waste samples and will both be subjected to chemical and radiation degradation during use at the waste treatment plant (WTP). The RPP-WTP process design assumes that resin batches can be used a minimum of 10 cycles before the resin must be replaced due to degradation. The effects of radiation and chemical degradation on SuperLig ${ }^{\circledR} 644$ and 639 resins were separately studied in the past under static conditions, i.e., in contact with air, water, and simulated waste solutions. To determine the chemical degradation effects under dynamic or column conditions, Battelle, Pacific Northwest National Laboratory (PNNL), and IBC Advanced Technologies conducted multiple load/elute/regenerate cycles with simulated Hanford waste samples. Savannah River Technology Center (SRTC) was contracted to demonstrate the performance of SuperLig ${ }^{\circledR} 644$ and 639 resins to treat repetitively radioactive waste solutions.

Six cycles of loading, elution, and regeneration were performed to remove ${ }^{137} \mathrm{Cs}$ from a Hanford waste sample retrieved from Tank 241-AW-101. Dual ion exchange columns of 0.57-inch $(1.45-\mathrm{cm})$ in diameter were installed in the Intermediate Level Cell (ILC \#2) in SRTC. The columns, designated as primary (lead) and polishing (lag) were each packed with approximately $5.3 \times 10^{-3} \mathrm{ft}^{3}(15 \mathrm{~mL})$ of SuperLig ${ }^{\circledR} 644$ resin. The cycles each consisted of processing AW-101 feed sample diluted to $5 \underline{\mathrm{M} \mathrm{Na}}{ }^{+}$, displacing residual feed from the column, eluting adsorbed ions, and conditioning the column to process the next feed solution. To ensure the lead columns experience the maximum degradation due to chemical and radiation exposure, the lead and lag columns were not reversed during the cyclic tests. Two additional ion exchange columns of 0.57 -inch $(1.45-\mathrm{cm})$ in diameter were installed in a radiochemical hood in SRTC. The columns were each packed with $4.24 \times 10^{-4} \mathrm{ft}^{3}(12 \mathrm{~mL})$ of SuperLig ${ }^{\circledR} 639$ resin. Five load/elute/regenerate cycles were carried out to remove ${ }^{99}$ Tc from cesium-depleted effluent solutions.

The multiple load/elute/regenerate cycles demonstrated that ${ }^{137} \mathrm{Cs}$ and ${ }^{99} \mathrm{Tc}$ can be effectively removed from a 241-AW-k1k01 sample using SuperLig ${ }^{\circledR} 644$ and 639 resins. A total $15 \mathrm{~L}$ of AW-101 waste sample at $5 \underline{\mathrm{M} \mathrm{Na}^{+}}$was processed through the SuperLig ${ }^{\circledR} 644$ ion exchange columns. The volume of AW-101 feed processed ranged from 168 to $225 \mathrm{BV}$ at $<50 \%$ breakthrough of ${ }^{137} \mathrm{Cs}$. The average ${ }^{137} \mathrm{Cs}$ decontamination factor (DF) achieved for the six cycles was $>1 \times 10^{4}$. The percent ${ }^{137} \mathrm{Cs}$ removal was $>99.99 \%$ for each of the six cycles.

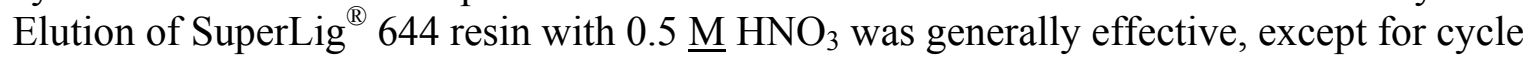
\#6, where strong tailing at the base was observed. The cumulative radiation exposure for the resin in the primary column (lead column) was $1.99 \times 10^{7}$ rad. Less than $24 \%$ reduction of resin loading capacity was observed after completion of the six load/elute/regeneration cycles. Thus, the overall performance of the dual ion exchange column was unchanged. All major chemical constituents in the feed reported to the pretreated product solutions and the RCRA characteristically hazardous elements were below TCLP limits. 
Approximately $250 \mathrm{BV}$ of AW-101 solution was processed at $<10 \%$ breakthrough of ${ }^{99} \mathrm{Tc}$. The percent of ${ }^{99} \mathrm{Tc}$ (pertechnetate) removal was $>99.94 \%$ for each of the five cycles.

Approximately $99 \%$ of the ${ }^{99} \mathrm{Tc}$ was eluted from resin in $<15 \mathrm{BV}$ using de-ionized water at $65^{\circ} \mathrm{C}$. The DF obtained for ${ }^{99} \mathrm{Tc}$ was on average $\sim 1.7 \times 10^{3}$ during the five cycles. Radiation dose was not expected to reduce SuperLig ${ }^{\circledR} 639$ resin capacity and, therefore, was not an issue in this test. 


\subsection{SUMMARY OF TESTING}

\subsection{OBJECTIVES}

The objectives of the multiple loading/elution tests were to:

- Demonstrate that SuperLig ${ }^{\circledR} 644$ and 639 resins can be used repetitively to treat radioactive waste solutions

- Quantify reduction in exchange capacity for each resin as a function of the number of loading/elution cycles

- Produce and characterize cesium and technetium eluate solutions for use in eluate evaporation tests (separate test specification)

- Pretreat the AW-101 sample to reduce the concentrations of $\mathrm{Cs}^{137}$ and $\mathrm{Tc}^{99}$ to meet LAW vitrification criteria

- Analyze the spent ion exchange resins to determine residual radionuclide and metals content, and to perform a modified (due to sample size) Toxicity Characteristic Leaching Procedure to determine the spent resin waste disposal pathways

\subsection{CONDUCT OF TESTING}

Multiple column load/elute/regenerate cycles were performed to remove ${ }^{137} \mathrm{Cs}$ and ${ }^{99} \mathrm{Tc}$ from the Hanford Tank 241-AW-101 waste sample using SuperLig ${ }^{\circledR} 644$ and 639 resins, respectively. Cesium removal tests were performed in the Intermediate Level Cell (ILC \#2) at the Savannah River Technology Center to provide shielding from radiation emitted by the high concentrations of ${ }^{137} \mathrm{Cs}$ in the feed. The tests were conducted as follows:

Actual Hanford waste solutions from Tank 241-AW-101 were passed downward through two ion exchange columns made of borosilicate glass tubing of $0.57-$ inch $(1.45-\mathrm{cm})$ in diameter. The columns, each of which contained $15 \mathrm{~mL}$ (5.156 g) of $\mathrm{N}_{2}$-dried SuperLig ${ }^{\circledR} 644$ resin, were used to remove ${ }^{137} \mathrm{Cs}$ from the waste sample. The AW-101 waste sample was previously diluted to $5 \underline{\mathrm{M} \mathrm{Na}}{ }^{+}$. Two additional columns of the same size, each of which contained $12 \mathrm{~mL}(7.366 \mathrm{~g})$ of $\mathrm{N}_{2}$-dried SuperLig ${ }^{\circledR} 639$ resin, were used to remove ${ }^{99} \mathrm{Tc}$ from the waste sample. The columns were arranged in series during loading and were referred to as the "lead" and "lag" columns. Prior to column loading, the columns were regenerated separately with $0.25 \underline{\mathrm{M} \mathrm{NaOH}}$. Column loaded with SuperLig ${ }^{\circledR} 644$ to remove ${ }^{137} \mathrm{Cs}$ utilized flow rate of $0.48-0.69 \mathrm{BV} / \mathrm{h}$, which were lower than the RPP design flow rate of $3 \mathrm{BV} / \mathrm{h}$. The reason for the deviation from the design flow rate was to increase the dose to the resin during the loading step. Columns used to remove ${ }^{99} \mathrm{Tc}$ were loaded at WTP design flow rate of 3 $\mathrm{BV} / \mathrm{h}$. Elution of the cesium columns utilized $0.5 \underline{\mathrm{M}} \mathrm{HNO} 3$ at $1 \mathrm{BV} / \mathrm{h}$ and $25^{\circ} \mathrm{C}$. Technetium elution was performed using de-ionized water at $1 \mathrm{BV} / \mathrm{h}$ and $65^{\circ} \mathrm{C}$. The details of the column testing procedure are presented in section 3 (Experimental section). 
The tests were performed according to the "Task Technical and Quality Assurance Plan for Cesium and Technetium Ion Exchange Using Tank 241-AW-101 Sample (U)"12. The Task Plan was generated from the "Task Specification for Cesium and Technetium Ion Exchange Using Tank 241-AW-101 Sample"13. Test exceptions were documented in 24590-WTPTEF-RT-02-077.

\subsection{RESULTS AND PERFORMANCE AGAINST OBJECTIVES}

The objectives of the multiple column load/elute/regenerate tests were to evaluate the combined chemical and radiation effects on $\mathrm{Cs}$ and Tc removal from actual Hanford waste sample from Tank 241-AW-101. The longevity of SuperLig ${ }^{\circledR} 644$ and 639 resins to treat radioactive waste solutions was demonstrated in six load/elute/regenerate cycles for cesium and five cycles for technetium. The results showed that SuperLig ${ }^{B} 644$ and 639 resins can be used repeatedly to remove ${ }^{137} \mathrm{Cs}$ and ${ }^{99} \mathrm{Tc}$ from radioactive waste samples. After six cycles, the cumulative dose to the SuperLig ${ }^{\circledR} 644$ resin was $1.99 \times 10^{7}$ rad and the measured cesium capacity loss for the lead column was approximately $31 \%$. Since the dose to resin was significantly below the $10^{8}$ rad threshold at which radiation damage to the resin becomes significant, the loss of resin capacity was due to chemical degradation ${ }^{8}$.

The SuperLig ${ }^{\circledR} 639$ resin performance was very good. The average loading volume during the five load/elute/regenerate cycles was about 250 BV. Since cesium was removed a priori by SuperLig ${ }^{\circledR} 644$ columns, the dose to resin was not an issue for technetium columns. Hence, no attempt was made to calculate the cumulative dose to the SuperLig ${ }^{\circledR} 639$ resin. Technetium removal from all but three tanks at the Hanford Site meets Class A specifications. Further, the RPP-WTP has recently determined that technetium removal from the remaining three tanks is not required.

Elution of cesium from SuperLig ${ }^{\circledR} 644$ was as expected for cycles 1-5. Approximately $99 \%$ of the cesium was eluted in less than $12 \mathrm{BV}$, at flow rates that varied from 0.5 (cycle \#1) to 1 $\mathrm{BV} / \mathrm{h}$ (cycles \#2 to \#6). Elution of the resin during cycle \#6 tailed strongly at the base. The elution tail extended from about 13 to $24 \mathrm{BV}$ before reaching a target C/Co of 0.01 . Technetium was eluted very effectively from SuperLig ${ }^{\circledR} 639$ using de-ionized water at $65^{\circ} \mathrm{C}$.

Analyses of the feed and product solutions show that the treated effluent from the lag column had overall cesium and technetium decontamination factors (DFs) of $>1 \times 10^{4}$ and $1.7 \times 10^{3}$, respectively. The percent removal of ${ }^{137} \mathrm{Cs}$ from the AW-101 sample was better than $>99.99 \%$ for all six cycles; the percent removal of ${ }^{99} \mathrm{Tc}$ (pertechnetate) exceeded $99.94 \%$ for the five cycles. The effluent composite product analysis showed that all major constituents in the feed were accounted in the effluent product solutions. Large dilutions prevented detection of most analytes in cesium and technetium eluate product solutions. The analysis of SuperLig ${ }^{\circledR} 644$ and 639 spent resins from the lead columns showed all RCRA characteristically hazardous elements were below theoretical TCLP limits. A detailed analysis of the results will be provided in Section 4 (Results and Discussions) of the report. 


\subsection{QUALITY REQUIREMENTS}

SRTC conducted this work in accordance with the quality assurance (QA) plan approved by the RPP-WTP QA organization. SRTC has provided to WTP matrices contained in the task and technical QA Plan, demonstrating compliance of the SRTC QA program with the requirements specified by WTP. (Note: since the goal of spent resin analysis was not longer for environmental permitting, the requirement of the QAPjP (PL-24590-QA00001) was not applicable. The work was conducted to the requirements of NQA-1 1989, Part 1, Basic and Supplementary Requirements and NQA-2a 1990, Subpart 2.7, as indicated by the QA Plan Checklist in Section VIII of reference 12. The work was also implemented in accordance with the WSRC Quality Assurance Program, which has been approved by WTP. The measuring and test equipment used in the testing is in compliance with the SRS QA Program. The data collected and reported was verified by an independent technical reviewer.

\subsection{ISSUES}

None 
WSRC-TR-2003-00098, REVISION 0

SRT-RPP-2003-00026, REVISION 0

This page intentionally left blank. 


\subsection{INTRODUCTION}

The River Protection Project Waste Treatment Plant (RPP-WTP) has identified a process to vitrify Hanford tank waste into low activity and high level waste glass wasteforms. The process includes sludge washing, filtration, precipitation, and ion exchange unit operations. Each of these operations removes certain radionuclides from the bulk of the waste and produces a relatively small volume of high level waste (HLW) sludge. This sludge is vitrified with glass forming compounds as high activity level glass. The remaining Low Activity Waste (LAW) after pretreatment contains the bulk of the waste volume and is vitrified as a low activity glass.

Removal of ${ }^{137} \mathrm{Cs}$ and ${ }^{99} \mathrm{Tc}$ is required to produce low activity waste from Hanford tank waste supernates using two ion exchange resins, SuperLig ${ }^{\circledR} 644$ and 639 from IBC Advanced Technologies, American Fork, Utah. Extensive experimental investigations were conducted at Savannah River Technology Center (SRTC) and Battelle, Pacific Northwest National Laboratory (PNNL) with actual waste samples from Tanks 241-AW-101, 241-AN-103, 241-AN-102, 241-AZ-102, 241-AN-107, 241-AP-101, and a mixture of 241-AN-102 and a leachate from $\mathrm{C}-104$ sludge. ${ }^{1-7}$ The experiments focused on the decontamination factors produced by the resins for ${ }^{137} \mathrm{Cs}$ and ${ }^{99} \mathrm{Tc}$ removal from each of the waste tanks. The radiation stability of SuperLig ${ }^{\circledR} 644$ was studied under static conditions (i.e., batch irradiation tests with resins in contact with air, water, and simulant waste solution $)^{5,8,9}$. The effects of chemical degradation were studied by IBC Advanced Technologies and Battelle, PNNL with simulated Hanford waste samples ${ }^{10,11}$. These studies were to quantify the decrease in resin performance due to combined effects of radiation and chemical degradation and to provide information on the RCRA metals and radionuclide contents of the spent resins.

The objective of this work was to perform multiple ion exchange column tests using Hanford tank waste supernatants from Tank 241-AW-101. The multiple load/elute/regenerate tests will quantify the decrease in ion exchange capacity and the loss of SuperLig ${ }^{\circledR} 644$ and 639 resin performance as a function of received dose. The multiple column tests were also aimed at producing pretreated product solutions for use in the LAW glass vitrification and assessing the disposal pathways for the spent resins. The experiments were performed according to the "Task Technical and Quality Assurance Plan for Cesium and Technetium Ion Exchange Using Tank 241-AW-101 Sample (U)". 12 The Task Plan was generated from the "Task Specification for Cesium and Technetium Ion Exchange Using Tank 241-AW-101 Sample". ${ }^{13}$ This report will present the results from the multiple cycle tests and will discuss the resin performance as a function of the cycles. 
WSRC-TR-2003-00098, REVISION 0

SRT-RPP-2003-00026, REVISION 0

This page intentionally left blank.

$-8-$ 
WSRC-TR-2003-00098, REVISION 0

SRT-RPP-2003-00026, REVISION 0

\subsection{EXPERIMENTAL}

\subsection{FEED PREPARATION}

A total of thirty 500-mL glass jars of waste samples from Tank 241-AW-101 were received at SRTC in January and March 2001. The 500-mL grab samples were obtained from riser 22 of the 241-AW-101 waste tank in July, 2000. The as-received 241-AW-101 samples were mixed together. They were then diluted with deionized water to provide supernate with a $5 \mathrm{M} \mathrm{Na}^{+}$concentration. The dilution was performed in the High Level Cells (HLC) at SRTC. After dilution the bulk solution was sampled and analyzed. The homogenization, dilution, and characterization of diluted bulk solution was reported by Hay. ${ }^{14}$

The bulk solution was filtered through a 0.1 -micron sintered metal Mott crossflow filter to remove entrained solids. ${ }^{15} \mathrm{~A}$ total $15 \mathrm{~L}$ of the AW-101 filtrate at $5 \mathrm{M} \mathrm{Na}^{+}$was transferred from the HLC to the Intermediate Level Cell (ILC) in 4-L polyethylene bottles. After the transfer to the ILC, the solutions in individual transfer bottles were not further homogenized. However, randomly selected bottles were analyzed by gamma energy counting and ICP-AES to determine the concentration of ${ }^{137} \mathrm{Cs}$ and metals, respectively. The total cesium was determined by ICP-MS. It was found to be 3.8 times the amount of ${ }^{137} \mathrm{Cs}$ present in waste sample. The total cesium includes ${ }^{133} \mathrm{Cs},{ }^{135} \mathrm{Cs},{ }^{136} \mathrm{Cs}$, and ${ }^{137} \mathrm{Cs}$. The solutions in the individual transfer bottles were used for multiple ion exchange column loading/elution testing.

A simulant representing the $\mathrm{AW}-101$ waste sample was prepared from the best available recipe. ${ }^{16}$ Approximately $1.5 \mathrm{~L}$ of the simulant at $\sim 5 \mathrm{M}$ sodium concentration was prepared. After preparation the simulant was allowed to stand for 24 hours, then filtered through a $0.45-\mu \mathrm{m}$ filter. Duplicate samples of the filtrate were analyzed to determine the concentrations of $\mathrm{Cs}, \mathrm{Re}$, metals, anions, hydroxide, and total organic carbon. The compositions of the diluted AW-101 actual waste and simulant solutions are shown in Table 3-1.

\subsection{RESIN PROPERTIES}

SuperLig ${ }^{\circledR} 644$ was used to remove ${ }^{137}$ Cs from the AW-101 waste sample while SuperLig ${ }^{\circledR}$ 639 resin was used for ${ }^{99} \mathrm{Tc}$ removal. The resins were developed and supplied by IBC Advanced Technologies, American Fort, Utah. The SuperLig ${ }^{\circledR} 644$ (batch \# I-D5-03-06-02$35-60$, also called the "one-gallon batch") was received wet in the hydrogen form. A small mass of the resin was dried under nitrogen at room temperature and then stored in a tightcapped bottle prior to use in batch contact and column load/elute/regenerate testing. The SuperLig ${ }^{\circledR} 639$ (batch \# I-R2-03-27-02-20-45) was received wet in de-ionized water. A small mass of the resin was dried under nitrogen at room temperature for use in batch and column load/elute/regeneration testing. 
WSRC-TR-2003-00098, REVISION 0

SRT-RPP-2003-00026, REVISION 0

Table 3-1. Composition of AW-101 Feed Samples

\begin{tabular}{|c|c|c|c|}
\hline Analyte & AW-101, ILC & AW-101, HLC & Simulant \\
\hline${ }^{99} \mathrm{Tc}, \mu \mathrm{g} / \mathrm{L}$ & $4.02 \mathrm{E}+03$ & $\mathrm{~nm}$ & na \\
\hline${ }^{99} \mathrm{Tc}^{*}, \mu \mathrm{Ci} / \mathrm{mL}$ & $6.62 \mathrm{E}-02$ & $7.31 \mathrm{E}-02$ & na \\
\hline${ }^{137} \mathrm{Cs}, \mu \mathrm{Ci} / \mathrm{mL}$ & $1.75 \mathrm{E}+02$ & $1.76 \mathrm{E}+02$ & na \\
\hline${ }^{133} \mathrm{Cs}, \mu \mathrm{g} / \mathrm{L}$ & $4.16 \mathrm{E}+03$ & $4.74 \mathrm{E}+03$ & $\mathrm{~nm}$ \\
\hline${ }^{135} \mathrm{Cs}, \mu \mathrm{g} / \mathrm{L}$ & $1.46 \mathrm{E}+03$ & $1.46 \mathrm{E}+03$ & $\mathrm{~nm}$ \\
\hline${ }^{136} \mathrm{Cs}, \mu \mathrm{g} / \mathrm{L}$ & $9.22 \mathrm{E}+01$ & & $\mathrm{~nm}$ \\
\hline${ }^{137} \mathrm{Cs}, \mu \mathrm{g} / \mathrm{L}$ & $2.05 \mathrm{E}+03$ & $2.08 \mathrm{E}+03$ & na \\
\hline Total Cs, $\mu \mathrm{g} / \mathrm{L}$ & $7.76 \mathrm{E}+03$ & $\mathrm{~nm}$ & $8.59 \mathrm{E}+03$ \\
\hline Total Cs, M & $5.84 \mathrm{E}-05$ & $\mathrm{~nm}$ & $6.46 \mathrm{E}-05$ \\
\hline Total carbon, $\mu \mathrm{g} / \mathrm{L}$ & $2.21 \mathrm{E}+03$ & & $2.75 \mathrm{E}+03$ \\
\hline $\mathrm{TIC}, \mathrm{mg} / \mathrm{L}$ & $8.52 \mathrm{E}+02$ & $9.18 \mathrm{E}+02$ & $1.05 \mathrm{E}+03$ \\
\hline $\mathrm{TOC}, \mathrm{mg} / \mathrm{L}$ & $1.36 \mathrm{E}+03$ & $9.92 \mathrm{E}+02$ & $1.70 \mathrm{E}+03$ \\
\hline Free $\mathrm{OH}-, \mathrm{M}$ & $1.81 \mathrm{E}+00$ & $1.94 \mathrm{E}+00$ & $1.78 \mathrm{E}+00$ \\
\hline${ }^{238} \mathrm{U} / \mathrm{Pu}, \mathrm{ug} / \mathrm{L}$ & $1.56 \mathrm{E}+03$ & $\mathrm{nn}$ & $\mathrm{nm}$ \\
\hline${ }^{238} \mathrm{U} / \mathrm{Pu}, \mathrm{M}$ & $6.57 \mathrm{E}-03$ & $\mathrm{~nm}$ & $\mathrm{~nm}$ \\
\hline specific gravity & $1.25 \mathrm{E}+00$ & $1.25 \mathrm{E}+00$ & $1.25 \mathrm{E}+00$ \\
\hline \multicolumn{4}{|l|}{ IC (anions), $\mathrm{M}$} \\
\hline $\mathrm{Cl}^{-}$ & $6.94 \mathrm{E}-02$ & $7.67 \mathrm{E}-02$ & $6.71 \mathrm{E}-02$ \\
\hline $\mathrm{F}^{-}$ & $9.48 \mathrm{E}-02$ & $1.42 \mathrm{E}-02$ & 3.79E-03 \\
\hline $\mathrm{HCOO}^{-}$ & $2.43 \mathrm{E}-02$ & $2.32 \mathrm{E}-02$ & $2.22 \mathrm{E}-03$ \\
\hline $\mathrm{NO}_{3}^{-}$ & $1.25 \mathrm{E}+00$ & $1.56 \mathrm{E}+00$ & 6.84E-01 \\
\hline $\mathrm{NO}_{2}^{-}$ & $9.97 \mathrm{E}-01$ & $1.13 \mathrm{E}+00$ & $7.98 \mathrm{E}-01$ \\
\hline$(\mathrm{C} 2 \mathrm{O} 4)_{2}^{-}$ & $2.58 \mathrm{E}-03$ & $3.28 \mathrm{E}-03$ & $1.12 \mathrm{E}-03$ \\
\hline $\mathrm{PO}_{4}^{-}$ & 4.70E-03 & $\mathrm{nm}$ & $2.06 \mathrm{E}-03$ \\
\hline $\mathrm{SO}_{4}^{-}$ & $1.77 \mathrm{E}-03$ & $1.51 \mathrm{E}-03$ & $1.64 \mathrm{E}-03$ \\
\hline \multicolumn{4}{|l|}{ ICP-AES, M } \\
\hline $\mathrm{Al}$ & 4.74E-01 & $6.04 \mathrm{E}-01$ & $5.02 \mathrm{E}-01$ \\
\hline $\mathrm{B}$ & $1.68 \mathrm{E}-04$ & $1.68 \mathrm{E}-03$ & 3.89E-05 \\
\hline $\mathrm{Ba}$ & $2.58 \mathrm{E}-06$ & $2.98 \mathrm{E}-05$ & $1.34 \mathrm{E}-04$ \\
\hline $\mathrm{Ca}$ & $1.97 \mathrm{E}-05$ & $1.56 \mathrm{E}-04$ & $6.06 \mathrm{E}-04$ \\
\hline $\mathrm{Cd}$ & $3.07 \mathrm{E}-07$ & $1.51 \mathrm{E}-05$ & $2.49 \mathrm{E}-07$ \\
\hline $\mathrm{Cr}$ & $9.17 \mathrm{E}-05$ & $9.67 \mathrm{E}-04$ & $2.56 \mathrm{E}-05$ \\
\hline $\mathrm{Cu}$ & $9.08 \mathrm{E}-06$ & $\mathrm{~nm}$ & $1.57 \mathrm{E}-06$ \\
\hline $\mathrm{Fe}$ & 5.64E-06 & 3.84E-05 & $9.80 \mathrm{E}-05$ \\
\hline $\mathrm{K}$ & $4.68 \mathrm{E}-01$ & $5.98 \mathrm{E}-01$ & $4.27 \mathrm{E}-01$ \\
\hline $\mathrm{Na}$ & $5.09 \mathrm{E}+00$ & $4.96 \mathrm{E}+00$ & $4.87 \mathrm{E}+00$ \\
\hline $\mathrm{Na} / \mathrm{K}$ & $1.09 \mathrm{E}+01$ & $8.28 \mathrm{E}+00$ & $1.14 \mathrm{E}+01$ \\
\hline $\mathrm{Na} / \mathrm{Al}$ & $1.08 \mathrm{E}+01$ & $8.20 \mathrm{E}+00$ & $9.70 \mathrm{E}+00$ \\
\hline $\mathrm{Na} / \mathrm{Cs}$ & $8.81 \mathrm{E}+04$ & $\mathrm{~nm}$ & $7.54 \mathrm{E}+04$ \\
\hline $\mathrm{K} / \mathrm{Cs}$ & $8.11 \mathrm{E}+03$ & & $6.61 \mathrm{E}+03$ \\
\hline
\end{tabular}

(see ref. 14)

$\mathrm{nm}=$ not measured; na $=$ not applicable 
The physical properties measured for the resins were bulk density, particle (skeletal) density, F-factor, and particle size distribution. The bulk density was determined by weighing a small mass of nitrogen-dried resin into a graduated cylinder filled with de-ionized water and measuring the resin volume after tamping the cylinder walls to obtain uniform packing. The skeletal density was determined using a pycnometer. The F-Factor (ratio of oven-dried mass to nitrogen-dried mass of the resin) was determined by weighing approximately $2.205 \times 10^{-3} \mathrm{lb}(1.0 \mathrm{~g})$ of resin and drying in a vacuum oven at $45 \pm 5^{\circ} \mathrm{C}$ until a constant mass was obtained. The metals content $\left(\mathrm{Na}^{+}\right.$and $\left.\mathrm{K}^{+}\right)$in the "as received" resins was determined by inductively coupled plasma-atomic emission spectroscopy (ICP-AES) analysis of the digested resins. The particle size distributions (PSD) were determined by dry sieve analysis on nitrogen-dried resin. The wet particle size distribution of the resin was determined using a Lazentec instrument. Some physical properties of the SuperLig ${ }^{\circledR} 644$ and 639 resins are presented in Table 3-2.

Table 3-2. Properties of SuperLig ${ }^{\circledR} 644$ and 639 Resins

\begin{tabular}{|l|c|c|}
\hline Property & SuperLig $^{\circledR}$ 644 & SuperLig $^{\circledR}$ 639 \\
\hline Batch ID & I-D5-03-06-02 & I-R-30-27-02 \\
\hline F-Factor & 0.64 & 0.98 \\
\hline $\begin{array}{l}\text { Bulk density } \\
\text { (nitrogen-dried basis) }\end{array}$ & $0.24 \mathrm{~g} / \mathrm{mL}$ & $0.41 \mathrm{~g} / \mathrm{mL}$ \\
\hline Skeletal density & $1.56 \mathrm{~g} / \mathrm{mL}$ & $\mathrm{nm}$ \\
\hline Particle size & $35-60 \mathrm{mesh}$ & $20-45 \mathrm{mesh}$ \\
\hline Mean particle size & $425 \mathrm{micron}$ & $475 \mathrm{micron}$ \\
\hline Metals - Na, K (mg/g) & $0.64,0.03$ & $\mathrm{~nm}$ \\
\hline
\end{tabular}

$\mathrm{nm}=$ not measured

\subsection{EQUIPMENT}

The equipment for batch contact testing for cesium and rhenium (surrogate for Tc) included an incubator shaker, filtration unit, a vacuum oven for F-Factor determination, an analytical balance, a high precision thermometer, and $20-\mathrm{mL}$ high density polyethylene bottles. New Brunswick Scientific Co., Edison New Jersey, supplied the incubator shaker (model C24), Nalgene Nunc International, Rochester, New York, supplied Nalgene ${ }^{\circledR}$ filter units, and the analytical balance (model AG285) was obtained from Mettler Toledo, Ohio. The analytical balance was accurate to $\pm 0.001 \mathrm{~g}$. A high precision $\left(0.01{ }^{\circ} \mathrm{C}\right)$ thermometer traceable to National Institute of Standards and Testing (NIST) calibration was mounted in polyethylene bottles containing de-ionized water to record the temperature in the incubator shaker environment. A house-supplied vacuum and a trap assembly were used during sample filtration. In the cell, a smaller Maxi Mix III orbital shaker was used instead of an incubator shaker to perform batch contact testing with the actual AW-101 waste solutions. The shaking speed of the orbital shaker was sufficient to swirl the solution and resin without excessive agitation, which might damage the resin. 
The experimental apparatus for the ion exchange column tests were dual glass columns, FMI pumps, auto-sampling units, and a constant temperature water-bath circulator. The apparatus was housed in the intermediate level cell in SRTC. The columns were made of borosilicate glass tube with adjustable plungers on the tops. The inside diameter of the columns was 0.57 -inch $(1.45-\mathrm{cm})$ and the total length was 6 inches $(15 \mathrm{~cm})$. When connected in series, the primary column was referred to as the "lead," while the secondary column was referred to as the "lag." The outside of the column walls was coated with a layer of clear polyvinyl chloride to reduce hazards associated with potentially pressurizing the columns. A ruler affixed to the column walls allowed visual observation of the resin bed height and liquid level changes during column runs. The adjustable plungers at the top of the columns were used to eliminate freeboard (headspace) liquid and to minimize the volumes of secondary waste generated. The columns were equipped with SRTC-patented 200-mesh screens to hold the resin in place. A closed-loop constant-temperature water-bath circulator pumped water through the jacket around the columns to provide precise bed temperature control. All tubing connections were made of polypropylene lines, which had Teflon ${ }^{\circledR}$ quick-connect fittings attached to each end. Solutions were passed downward through the columns.

Liquid delivery into the columns was accomplished using FMI metering pumps (model RP-1, Fluid Metering, Inc. Oyster Bay, NY). The pump heads had shaft sizes of 1/18", 1/4", and $3 / 8^{\prime \prime}$ to produce desired wide range of desired flow rates. The pumps were run at the desired flow rates by specifying the rotational speed of the motor (RPM), which was driven by direct current (D.C). The pump controllers/readout were located in a service console outside the cell. Volumetric flow rates were determined from the mass of lag column effluent composite fractions, the density, and the time to collect the effluent composite fractions.

\subsection{SAMPLING AND ANALYSIS}

Sampling the ion exchange columns was accomplished using custom-designed auto-sampling apparatus. The apparatus consisted of assembly pieces that can be directly installed in the hot cell. The main piece was an electrically actuated six-position rotary valve with $1 / 16^{\prime \prime}$ flangeless tubing. The valve was mounted on an aluminum plate, 3 " tall x 3 " wide. At the bottom of the valve, six holes were drilled on the back of a second support plate (6" tall x 6" wide) and six stainless steel tubes (1/16" ID) were connected through ball head fittings. Polypropylene tubing (1/16" ID) was used to connect the rotary valve to the stainless steel tubing, which directed samples into sample vials. The carousel slipped into a section-groove (5/8" deep x 3 " long) in the middle of a solid polyethylene block (4 1/2" long x 3 " wide $x$ $21 / 2$ " high) for support. The carousel and the solid block were then raised by a small jiffyjack to align the vials with stainless steel tubing, which delivered the sample into the sample vials in a way that minimized evaporation during sampling was minimized. The rotary valve was controlled from a service console located outside of the cell and involved no use of a cell manipulator. Instructions were provided to allow the rotary valve to be programmed for unattended sampling. 
The basic sampling mechanism was to divert small aliquots $(\sim 6 \mathrm{~mL})$ of the column effluent into one of five sampling valve positions for collection in vials. A valve opened every 14 hours and 15 minutes to collect samples in an 8-mL glass vial for 45 minutes. Dilution of each sample by residual liquid in the valve tubing during a sampling event was less than $10 \%$. However, this created unexpected data spikes in the loading data for several cycles, for which the rinse and purge of the liquid out of the valve tubing after elution was incomplete.

Samples of the effluent were collected from the lead column in $10 \mathrm{BV}$ increments. The lag column was sampled every $20 \mathrm{BV}$. The samples were submitted to the Analytical Development Section (ADS) and analyzed per approved procedures. The analyses performed included inductively coupled plasma -atomic emission spectroscopy (ICP-AES) metals and ${ }^{99} \mathrm{Tc}$, ion chromatography (IC) - anions, gamma energy analysis (GEA) - ${ }^{137} \mathrm{Cs}$, inductively coupled plasma-mass spectroscopy (ICP-MS) - actinides, ${ }^{99} \mathrm{Tc}$ and Cs, total organic carbon (TOC), and free hydroxide $\left(\mathrm{OH}^{-}\right)$.

The ${ }^{99} \mathrm{Tc}$ concentration was determined by chemical separation and beta counting method. A 1 milliliter aliquot of the AW-101 sample was spiked with ${ }^{99 \mathrm{~m}} \mathrm{Tc}$ tracer and diluted with nitric acid to adjust the concentration to $0.2 \underline{\mathrm{M}} \mathrm{HNO}_{3}$. The $0.2 \underline{\mathrm{M}} \mathrm{HNO}_{3}$ solutions were added to pre-conditioned Eichrom TEVA columns. The columns were rinsed successively with dilute nitric and $1 \underline{\mathrm{M}} \mathrm{NaOH}$. The ${ }^{99} \mathrm{Tc}$ in the sample was eluted from the columns using two

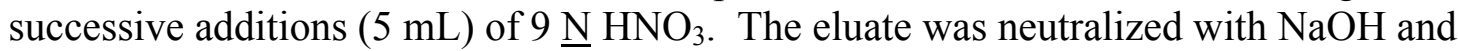
poured through Eichrom TEVA Discs, which were pre-conditioned with $0.1 \underline{\mathrm{N}}$ nitric, prior to assay. The Eichrom TEVA Discs were added to a liquid scintillation cocktail, analyzed by gamma spectrometry (to quantify Tc-99m recoveries) and then after a suitable decay period, liquid scintillation (LS) spectrometry was applied to quantify the ${ }^{99} \mathrm{Tc}$ (pure beta emitter) in the sample. The gamma measurements were conducted using a $\mathrm{NaI}$ well counter in conjunction with a Canberra Industries Genie2K gamma spectroscopy platform. Liquid scintillation analyses were conducted using a Packard Industries 2750AB Liquid Scintillation Analyzer. The details of this separation and beta counting method were reported by Sigg. ${ }^{17}$

\subsection{PROCEDURE}

\subsubsection{Batch Contact Tests}

Batch contacts were performed using the AW-101 actual waste and simulant solutions, and SuperLig ${ }^{\circledR} 644$ and 639 resins. The actual waste solution (AW-101) contained $175 \mu \mathrm{Ci} / \mathrm{mL}$ ${ }^{137} \mathrm{Cs}$ and $0.064 \mu \mathrm{Ci} / \mathrm{mL}^{99} \mathrm{Tc}$ (pertechnetate form). The bulk simulant (at $5 \underline{\mathrm{M} \mathrm{Na}}{ }^{+}$) contained $8.59 \times 10^{3} \mu \mathrm{g} / \mathrm{L}$ of Cs (total) and $4.73 \times 10^{3} \mu \mathrm{g} / \mathrm{L}$ of rhenium. The measurements were carried out in duplicate at a liquid volume to resin mass ratio (phase ratio) of 10 and 100. Typically, $3.53 \times 10^{-4} \mathrm{ft}^{3}(10 \mathrm{~mL})$ of the solution was added to $2.205 \times 10^{-4} \mathrm{lb}(0.1 \mathrm{~g})$ or $2.205 \times 10^{-3} \mathrm{lb}(1.0 \mathrm{~g})$ of nitrogen-dried resin in high-density polyethylene bottles. 
The volume of solution was transferred by pipette, but the mass and density of the solutions were used to determine the actual volume. The phase ratio of 10 was used to ensure that higher than detection values are obtained for competing ions. All contacts with resin were made for a period of 48 hours. Agitation was provided by an incubator shaker set at $275 \mathrm{rpm}$ for AW-101 simulant, and a Maxi Mix orbital shaker, adjusted between 400 and $600 \mathrm{rpm}$, was used for actual AW-101 waste solution. The temperature in the cell was not controlled, but was recorded as $25 \pm 1{ }^{\circ} \mathrm{C}$ during the period of contact. Duplicate control samples (i.e., solution without resin) were prepared and treated in the same manner as the contact samples. After the contact period of 48 hours, the solutions were separated from the ion exchange resins by filtration through a 0.45 -micron Nalgene ${ }^{\circledR}$ filter unit.

Small aliquots of the filtrate were analyzed by GEA to determine the ${ }^{137} \mathrm{Cs}$ concentrations. Inductively coupled plasma-mass spectroscopy (ICP-MS) was used to determine the concentrations of cesium (total) and rhenium (surrogate for technetium). Chemical separation and beta counting method was used to determine the ${ }^{99} \mathrm{Tc}$ (pertechnetate) concentration in filtered solutions. Aliquots of the control samples were diluted with 1:10 volume ratio of de-ionized water in order to reduce the dose rate and transfer samples out of the cell.

\subsubsection{Simulant Column Tests}

Single-column load/elute/regenerate tests were performed for cesium and rhenium (surrogate for technetium) removal from AW-101 simulant prepared per Eibling recipe ${ }^{16}$. The tests were aimed to confirm the ion exchange columns were properly functioning before processing AW-101 actual waste solution. Dual ion exchange columns (lead and lag) were connected in series during the loading phase. The columns were prepared as follows: A known mass of nitrogen-dried SuperLig ${ }^{\circledR} 644$ resin (batch \# I-D5-03-06-02-35-60) was weighed in a HDPE bottle. The resin was soaked in de-ionized water and then added through a funnel into the columns. An as-measured mass of $5.1562 \mathrm{~g}$ of the resin was added each into the lead column; the lag column contained $5.5313 \mathrm{~g}$. To ensure uniform packing of resin, the column walls were tapped gently with a rubber stopper while the resin particles were gravity settling in the columns. After the resin was added, the columns were each preconditioned with $12 \mathrm{BV}$ of $0.25 \underline{\mathrm{M} \mathrm{NaOH}}$. The pre-conditioning solution was pumped as down flow separately into the lead and lag columns at $3 \mathrm{BV} / \mathrm{h}$. The resin was allowed to stand in the pre-conditioning solution overnight. The volume of the swollen resin bed in the lead column was $\sim 14.8 \mathrm{~mL}$. The lag column had initial swollen bed volume of $\sim 16.5 \mathrm{~mL}$.

Rhenium (surrogate for technetium) columns were prepared by adding 7.3659 and 7.3651 grams of SuperLig ${ }^{\circledR} 639$ resin (batch \# I-R2-03-27-02-20-45) into two HDPE bottles. The resin in each bottle was soaked in $0.25 \underline{\mathrm{M} \mathrm{NaOH}}$ for one hour and then added into the columns designated as "lead" and "lag". The resin bed was constrained with quartz wool and 3-mm glass beads. Twelve BV's of $0.25 \underline{\mathrm{M}} \mathrm{NaOH}$ was pumped separately as down flow into each column at $3 \mathrm{BV} / \mathrm{h}$. The columns were stored in the $0.25 \underline{\mathrm{M} \mathrm{NaOH}}$ solution overnight. The SuperLig $^{\circledR} 639$ resin beds exhibited no swelling during overnight storage. 
After preconditioning, the lead and lag columns were connected in series. The feed was pumped as down flow with a single pump in the upstream position. Loading the columns was considered to start the moment the simulant contacted the liquid on top of the resin bed. The cesium and rhenium columns were loaded at 0.67 and $3 \mathrm{BV} / \mathrm{h}$, respectively. The effluent was collected in polyethylene bottles from the lag columns. The first $3 \mathrm{BV}$ of effluent were discarded as a waste because of the feed dilution with residual $\mathrm{NaOH}$ in the columns. The first effluent sample from the cesium column (lead) was collected manually after 5 BV of feed had passed through the column. Subsequent samples of effluent from the lead column were collected via the auto-sampler every $10 \mathrm{BVs}$. Individual samples of the effluent from the lag column were collected manually every 20 BVs. Samples of the effluent from the rhenium columns were collected at intervals of 10 and $20 \mathrm{BVs}$ for the lead and lag, respectively. The heights of the resin beds and the liquid levels in the columns were recorded several times during the day.

After loading, the columns were washed with $4 \mathrm{BV}$ of $0.1 \underline{\mathrm{M}} \mathrm{NaOH}$ solution and rinsed with $4 \mathrm{BV}$ of de-ionized water. The solutions were pumped as downflow through the lead into the lag column at $3 \mathrm{BV} / \mathrm{h}$. The effluent was collected from the bottom of the lag column and discarded as waste. The $0.1 \underline{\mathrm{M}} \mathrm{NaOH}$ solution was used to displace the feed and remove sodium aluminate from the columns prior to water washing. This was done to avoid aluminum precipitation on the resin beds. To avoid exothermic reaction with nitric acid during the elution, the $0.1 \underline{\mathrm{M} \mathrm{NaOH}}$ solution was displaced from the columns with deionized water rinse. The lead and lag columns were disconnected after completing the water rinse step. The columns were eluted separately.

Cesium elution was accomplished using $0.5 \mathrm{M} \mathrm{HNO}_{3}$ solution. Rhenium was eluted with deionized water at $65^{\circ} \mathrm{C}$. The lead and lag columns were eluted separately at $\sim 1.0 \mathrm{BV} / \mathrm{hr}$ and only the lead columns were sampled. Elution was considered to begin the moment the eluent contacted the liquid solution above the resin beds. The eluate passing from the bottom of each column was collected in polyethylene bottles. The eluate samples from the lead cesium ion exchange column were collected via the auto-samplers every $1 \mathrm{BV}$ or one hour for the first 5 hours. Sampling frequency was changed to every 2 BV or two hours for the next 10 hours. The eluate samples form the rhenium columns were collected in $1 \mathrm{BV}$ increments using an automatic fraction collector. Rhenium elution was continued for up to $26 \mathrm{BV}$. After elution, the columns were each washed separately with $4 \mathrm{BV}$ of deionized water at $1 \mathrm{BV} / \mathrm{h}$. The columns were stored in de-ionized water for several weeks prior to initiating the multiple cycle column tests. Samples of the eluate were analyzed by ICP-MS for cesium and rhenium concentrations. Composite samples of the cesium and rhenium eluate were also prepared and analyzed by ICP-MS. 


\subsubsection{Cesium Column Multi-Cycle Tests -Hot Cell}

Multiple column runs for cesium removal from the AW-101 waste sample were conducted in a shielded cell (Intermediate Level Cell or ILC \#2) in SRTC. The equipment for the cesium ion exchange was transferred from the chemical hood, where the simulant test was performed, to the hot cell. The ion exchange columns, pumps, auto-samplers were remotely installed inside the cell using remotely controlled manipulator arms. A photograph of the equipment in operation inside the hood is shown in Figure 3-1. A summary of the test conditions for the cesium and technetium ion exchange systems is shown in Table 3-3

Table 3-3. A Summary of the Test Conditions

\begin{tabular}{|c|c|c|}
\hline AW-101 Column Tests & SuperLig ${ }^{\circledR} 644$ & SuperLig ${ }^{\circledR} 639$ \\
\hline Column size, $\mathrm{cm}$ & 1.45 & 1.45 \\
\hline Dual column set-up & Lead \& lag & Lead \& lag \\
\hline Bed volume, $\mathrm{mL}$ & 15 & 12 \\
\hline Mass of resin/column, $\mathrm{g}$ & $5.1562(\mathrm{H}-\text { form })^{*}$ & 7.3659 \\
\hline Resin batch \# & I-D5-03-06-02-35-60 & I-R-03-27-02-20-45 \\
\hline Preconditioning solution & $0.25 \underline{\mathrm{M} N a O H}$ & $0.25 \underline{\mathrm{M}} \mathrm{NaOH}$ \\
\hline Displacement solution & $0.1 \underline{\mathrm{M}} \mathrm{NaOH}$ & $0.1 \underline{\mathrm{M}} \mathrm{NaOH}$ \\
\hline $\begin{array}{c}\text { Flow rate, } \mathrm{BV} / \mathrm{h} \\
\text { Loading } \\
\text { Displacement } \\
\text { Elution }\end{array}$ & $\begin{array}{l}0.48-0.69 \\
3.0 \\
1.0\end{array}$ & $\begin{array}{l}3.0 \\
3.0 \\
1.0\end{array}$ \\
\hline $\begin{array}{c}\text { Temperature } \\
\text { Loading } \\
\text { Elution }\end{array}$ & $\begin{array}{l}25{ }^{\circ} \mathrm{C} \\
25{ }^{\circ} \mathrm{C}\end{array}$ & $\begin{array}{l}25^{\circ} \mathrm{C} \\
65^{\circ} \mathrm{C}\end{array}$ \\
\hline Eluant & $0.5 \underline{\mathrm{M}} \mathrm{HNO}_{3}$ & De-ionized water \\
\hline $\begin{array}{c}\text { Sampling frequency, BV } \\
\text { Lead column } \\
\text { Lag column }\end{array}$ & $\begin{array}{l}10 \\
20\end{array}$ & $\begin{array}{l}10 \\
20\end{array}$ \\
\hline$\left[{ }^{137} \mathrm{Cs}\right] \mathrm{o}, \mu \mathrm{Ci} / \mathrm{mL}$ & 175 & NA \\
\hline$\left[{ }^{99} \mathrm{Tc}\right] \mathrm{o}, \mu \mathrm{Ci} / \mathrm{mL}$ & NA & 0.0662 \\
\hline
\end{tabular}




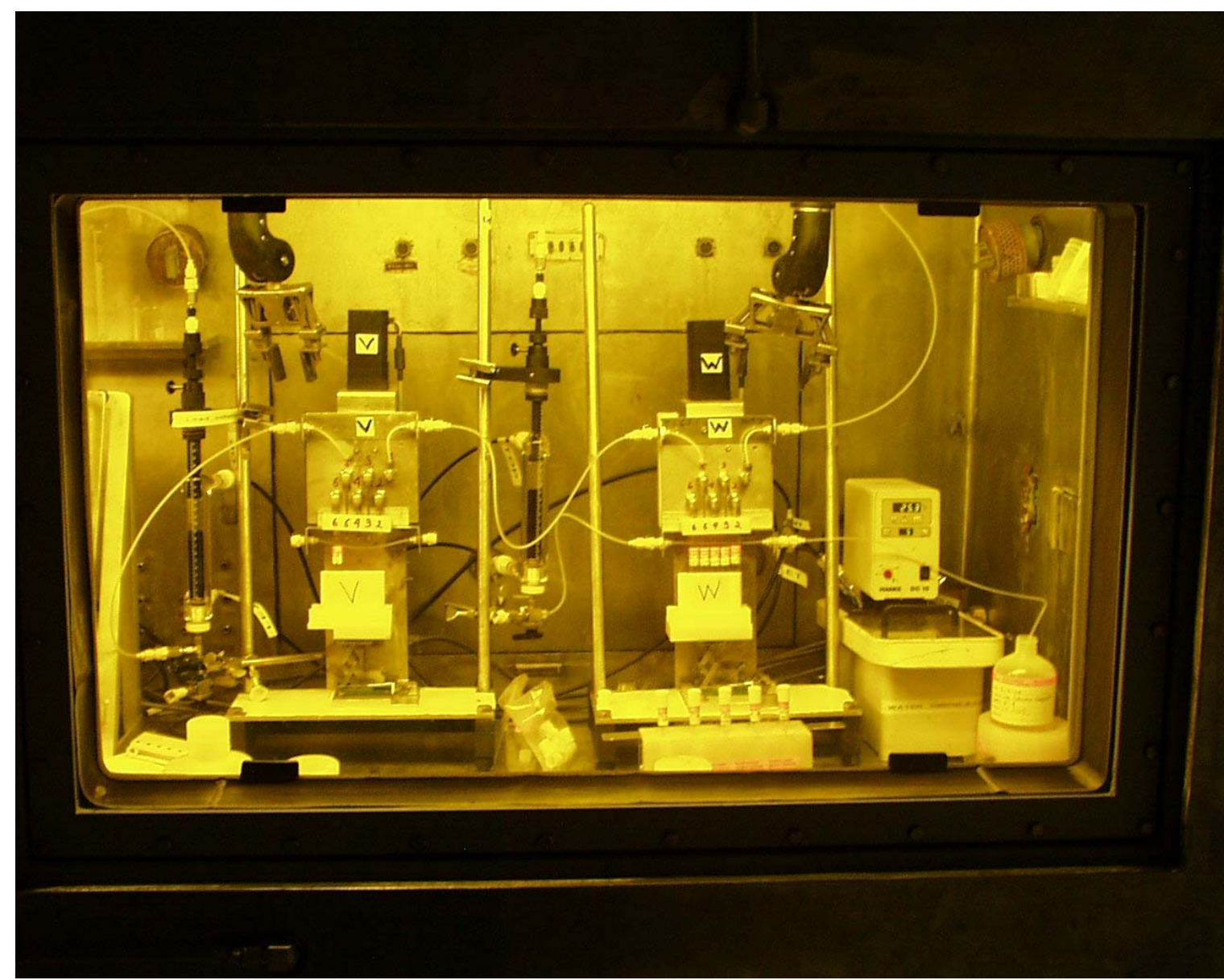

Figure 3-1. Photograph of Test Equipment in Operation Inside the Hot Cell

The lead and lag columns were each regenerated using $12 \mathrm{BV}$ of $0.25 \underline{\mathrm{M}} \mathrm{NaOH}$. The $0.25 \underline{\mathrm{M}}$ $\mathrm{NaOH}$ solution was pumped as down flow into each column at a flow rate of $3 \mathrm{BV} / \mathrm{h}$ and the effluent was collected in polyethylene bottles. The heights of resin beds and the liquid levels in the columns were measured during regeneration step. After regeneration, the lead and lag columns were connected in series. The pump delivering feed to the lead column was connected to a feed bottle containing diluted AW-101 sample. The pump was set to the target flow rate of $0.67 \mathrm{BV} / \mathrm{h}$, but the flow rates drifted slightly downward during the column runs. The low flow rate was chosen to maximize radiation exposure of resin bed in the lead column. The custom auto-sampler was programmed for the desired sample volume, frequency of collection, and number of samples. The pump was then turned on. Samples of the effluent from the lead and lag columns were collected every 10 and $20 \mathrm{BV}$, respectively. 
The column loading was considered to start when the feed contacted the liquid on top of the resin bed in the lead column. The heights of resin bed and the liquid level were measured for each column at this time. The initial $3 \mathrm{BV}^{\prime} \mathrm{s}$ of the effluent from the lag column, which contained $0.25 \underline{\mathrm{M} \mathrm{NaOH}}$ solution, were discarded into a waste residue bottle. Flow rate through the columns was initially verified by timing the collection of a small sample volume $(6 \mathrm{~mL})$ of the effluent from the bottom of the lag column. The volume and the time of its collection provided the check on the flow rate. Later, flow rates were determined by weighing composite effluent solutions from the lag column of about $20 \mathrm{BV}$ every $30 \mathrm{~h}$. The loading of the columns was continued until approximately $200 \mathrm{BV}$ of the AW-101 waste sample was processed. The composite effluent fractions collected from the lag column were weighed and the volume of each fraction was determined based on its mass and density. A sub-sample was taken from each composite fraction and analyzed for ${ }^{137} \mathrm{Cs}$.

After loading, a feed displacement $(0.1 \underline{\mathrm{M} \mathrm{NaOH}})$ and de-ionized water rinse were performed using $4 \mathrm{BVs}$ of each solution at a flow rate of $3 \mathrm{BV} / \mathrm{h}$. Once the columns were washed and rinsed, they were disconnected and then eluted separately with $0.5 \underline{\mathrm{M}} \mathrm{HNO}_{3}$. Elution was carried out as downward flow at $\sim 1 \mathrm{BV} / \mathrm{h}$. Samples of the eluate were collected via the auto-samplers every $1 \mathrm{BV}$ for the first $5 \mathrm{BVs}$ and every $2 \mathrm{BVs}$ until a total of $15 \mathrm{BVs}$ of the eluant was processed. Samples of the eluate and composite fraction from the lead column were analyzed only for ${ }^{137} \mathrm{Cs}$. The elution volume was determined using the original volume of the sodium hydroxide form resin beds during the loading phase, as a basis. When elution was complete, each resin bed was rinsed with $4 \mathrm{BVs}$ of de-ionized water at a flow rate of $1 \mathrm{BV} / \mathrm{h}$. The lead and lag columns were regenerated separately in a downward flow with $12 \mathrm{BVs}$ of $0.25 \underline{\mathrm{M} \mathrm{NaOH}}$ at $3 \mathrm{BV} / \mathrm{h}$. The procedure described above was repeated for each cycle.

\subsubsection{Technetium Column Runs}

The load/elute/regenerate experiments for ${ }^{99} \mathrm{Tc}\left(\mathrm{TcO}_{4}{ }^{-}\right.$form) was carried out inside a radiochemical hood. A photograph of the apparatus is shown in Figure 3-2. The load tests started after sufficient effluent were collected from the cesium column runs. The lead and lag columns were each regenerated using $12 \mathrm{BV}$ of $0.25 \mathrm{M} \mathrm{NaOH}$. The columns were regenerated separately at $3 \mathrm{BV} / \mathrm{h}$. After regeneration, the columns were connected in series and the solution was pumped as down flow at $3 \mathrm{BV} / \mathrm{h}$. After loading, the feed displacement step with $0.1 \underline{\mathrm{M} \mathrm{NaOH}}$. Samples of the feed solutions were collected at $0.5 \mathrm{BV}$ increments from the bottom of the lead column. The elution of the lead and lag columns was performed separately. The eluant (deionized water) bottle and the column jacket were preheated to $65{ }^{\circ} \mathrm{C}$. The eluent was pumped as down flow at $1 \mathrm{BV} / \mathrm{h}$. Eluate samples were collected every $0.5 \mathrm{BV}$ for the first $4 \mathrm{BVs}$ and the every $2 \mathrm{BVs}$ thereafter, until a total of $26 \mathrm{BVs}$ of eluent was processed. After elution, the columns were regenerated with $12 \mathrm{BV}$ of $0.25 \underline{\mathrm{M}}$ $\mathrm{NaOH}$ to prepare for the next cycle. 
WSRC-TR-2003-00098, REVISION 0 SRT-RPP-2003-00026, REVISION 0

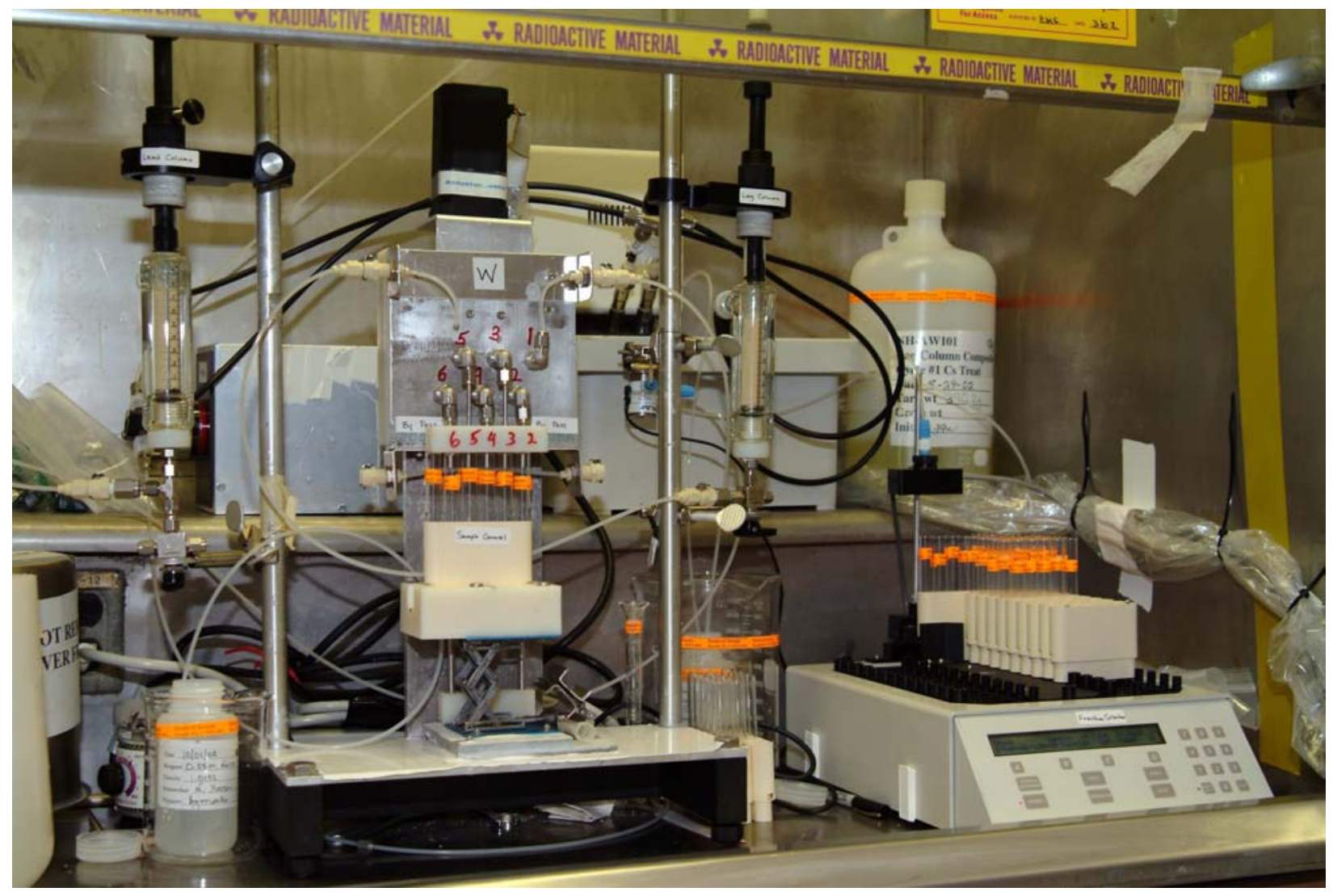

Figure 3-2. Photograph of Test Equipment in Operation Inside the Radiochemical Hood 
WSRC-TR-2003-00098, REVISION 0

SRT-RPP-2003-00026, REVISION 0

This page intentionally left blank. 


\subsection{RESULTS AND DISCUSSION}

\subsection{BATCH CONTACT TESTS}

Batch contact tests were aimed at measuring the equilibrium distribution coefficients $\left(\mathrm{K}_{d} \mathrm{~s}\right)$ for cesium and technetium. The $\mathrm{K}_{d} \mathrm{~S}$ were calculated according to the following equation:

\section{Equation 1}

$$
K_{d}=\left[\left(\frac{C_{o}}{C_{e}}\right)-1\right]\left[\frac{V}{M^{*} F}\right]
$$

where

$\mathrm{C}_{\mathrm{o}}$ and $\mathrm{C}_{\mathrm{e}}=$ the analyte concentration in the waste solution before and after contacting with resin

$\mathrm{V}=$ the volume of solution used

$\mathrm{M}=$ the mass of resin (nitrogen-dry in $\mathrm{H}$-form)

$\mathrm{F}=$ the $\mathrm{F}$-factor defined as the ratio of the nitrogen-dried resin mass to that of the oven-dried mass.

Typically, the distribution coefficients are measured at equilibrium so the data represents one point on the equilibrium isotherm. The $\mathrm{K}_{\mathrm{d}}$ is used as an indicator of the affinity of an ion towards the resin in the presence of a complex matrix of interfering ions.

In this work, the $\mathrm{K}_{\mathrm{d}}$ measurements were performed in duplicate at liquid to solid phase ratio of 100 and 10, at contact times of $48 \mathrm{~h}$. The cesium Kds for both AW-101 simulant and actual AW-101 waste solutions are presented in Table 4-1. The average $\mathrm{K}_{\mathrm{d}}$ of $1540 \mathrm{~mL} / \mathrm{g}$ is in good agreement with the value of $1317 \mathrm{~mL} / \mathrm{g}$ reported by Fiskum et al. ${ }^{18}$ using SuperLig $^{\circledR}$ 644 resin (batch \# BZ) and AW-101 simulant. The ${ }^{137} \mathrm{Cs} \mathrm{K}_{d}$ value of $1368 \mathrm{~mL} / \mathrm{g}$ for AW-101 actual waste sample compares reasonably well (i.e. within $30 \%$ ) with the $\mathrm{K}_{\mathrm{d}}$ value reported by Hassan and McCabe for unidentified batch of SuperLig ${ }^{\circledR}$ 644, using a liquid to solid ratio of 100 for a contact time of $24 \mathrm{~h}^{19}$

The ${ }^{99} \mathrm{Tc} \mathrm{K}_{\mathrm{d}} \mathrm{S}$ are presented in Table 4-2. The values of 802 and $238 \mathrm{mg} / \mathrm{L}$ were the average of duplicate measurements for ${ }^{99} \mathrm{Tc}$ (pertechnetate) at phase ratios of 100 and $10 \mathrm{~mL} / \mathrm{g}$, respectively. The reason for the decline of the $\mathrm{K}_{\mathrm{d}}$ obtained at the phase ratio of $10 \mathrm{~mL} / \mathrm{g}$ is not known. However, the density of SuperLig ${ }^{\circledR} 639$ was about the same as the AW-101 actual waste solution. Therefore, floating of the resin during the batch contact testing could have resulted in relatively poor contact of the resin and solution. The $\mathrm{K}_{\mathrm{d}}$ of $802 \mathrm{~mL} / \mathrm{g}$ obtained in this study is $47 \%$ less than the $\mathrm{K}_{\mathrm{d}}$ previously reported for $\mathrm{AW}-101$ actual waste solution by Hassan and McCabe. ${ }^{19}$ 
Table 4-1. $K_{d}$ s for Cesium in AW-101 Actual Waste and Simulant Solutions

\begin{tabular}{|c|c|c|c|c|c|c|}
\hline AW-101 Actual Waste & $\begin{array}{c}\text { phase ratio, } \\
\mathrm{mL} / \mathrm{g}\end{array}$ & $\begin{array}{c}\left.{ }^{137} \mathrm{Cs}\right]_{0}^{*} \\
(\mu \mathrm{Ci} / \mathrm{mL})\end{array}$ & $\begin{array}{c}{\left[{ }^{137} \mathrm{Cs}\right]_{\mathrm{e}}} \\
(\mu \mathrm{Ci} / \mathrm{mL})\end{array}$ & $\underset{(\mathrm{mL} / \mathrm{g})}{\mathrm{K}_{\mathrm{d}}}$ & $\begin{array}{l}\operatorname{avg} \cdot K_{d} \\
(\mathrm{~mL} / g)\end{array}$ & $\%$ RSD \\
\hline NH44-AW101-Kd-1 & 99 & 175 & 20.2 & 1268 & na & na \\
\hline NH44-AW101-Kd-1D & 98 & 175 & 17.6 & 1468 & 1368 & 10.4 \\
\hline NH44-AW101-Kd-2 & 9.7 & 175 & 1.1 & 2672 & na & na \\
\hline NH44-AW101-Kd-2D & 9.5 & 175 & 1.0 & 2810 & 2741 & 3.6 \\
\hline AW-101 Simulant & $\begin{array}{c}\text { phase ratio, } \\
\mathrm{mL} / \mathrm{g}\end{array}$ & $\begin{array}{c}{[\mathrm{Cs}]_{0}^{*}} \\
(\mu \mathrm{Ci} / \mathrm{mL})\end{array}$ & $\begin{array}{c}{[\mathrm{Cs}]_{\mathrm{e}}} \\
(\mu \mathrm{Ci} / \mathbf{m L})\end{array}$ & $\underset{(\mathrm{mL} / \mathrm{g})}{\mathrm{K}_{\mathrm{d}}}$ & $\begin{array}{l}\operatorname{avg} \cdot K_{d} \\
(\mathrm{~mL} / g)\end{array}$ & $\%$ RSD \\
\hline NH44-AW101Sim-Kd-1 & 98 & $9515^{*}$ & 896 & 1572 & na & na \\
\hline NH44-AW101Sim-Kd-1D & 98 & $9515^{*}$ & 932 & 1508 & 1540 & 2.9 \\
\hline
\end{tabular}

* [Cs $]_{0}$ measured in simulant control samples of $9.52 \times 10^{3} \mu \mathrm{g} / \mathrm{L}$ is $9.7 \%$ higher than $[\mathrm{Cs}]_{\mathrm{o}}$ of $8.59 \times 10^{3} \mu \mathrm{g} / \mathrm{L}$ in the bulk stimulant (see Table 3-1).

na $=$ not applicable

Table 4-2. $K_{d}$ s for Technetium in AW-101 Actual Waste Sample

\begin{tabular}{|c|c|c|c|c|c|c|}
\hline $\begin{array}{l}\text { AW-101 Actual Waste } \\
\text { Sample ID }\end{array}$ & $\begin{array}{c}\text { phase ratio, } \\
\mathrm{mL} / \mathrm{g}\end{array}$ & $\begin{array}{c}\left.{ }^{99} \mathbf{T c}\right]_{0} \\
(\mu \mathrm{Ci} / \mathbf{m L})\end{array}$ & $\begin{array}{c}\left.{ }^{99} \mathbf{T c}\right]_{0} \\
(\mu \mathrm{Ci} / \mathbf{m L})\end{array}$ & $\begin{array}{c}\mathbf{K}_{\mathbf{d}} \\
(\mathrm{mL} / \mathrm{g})\end{array}$ & $\begin{array}{l}\operatorname{avg} \cdot K_{d} \\
(\mathrm{~mL} / \mathrm{g})\end{array}$ & \% RSD \\
\hline NH39-AW101-Kd-1 & 96 & 4725 & 492 & 839 & na & na \\
\hline NH39-AW101-Kd-1D & 90 & 4725 & 508 & 766 & 802 & 6.4 \\
\hline NH39-AW101-Kd-2 & 9.5 & 4725 & 190 & 231 & na & na \\
\hline NH39-AW101-Kd-2D & 9.5 & 4725 & 181 & 245 & 238 & 4.1 \\
\hline
\end{tabular}

na $=$ not applicable 


\subsection{SIMULANT COLUMN TESTS}

Figure 4-1 displays the results for the AW-101 simulant lead column test. The cesium concentration profile $(\mathrm{C} / \mathrm{Co})$ was plotted in a log scale against the number of $\mathrm{BV}$ of simulant processed. In this run, we processed only $110 \mathrm{BV}$ of AW-101 simulant and a cesium breakthrough was not observed. Elution of the lead and lag columns was carried out separately at $25 \pm 1{ }^{\circ} \mathrm{C}$ and at a flow rate of $\sim 1 \mathrm{BV} / \mathrm{h}$. The columns were eluted with down flow of $15 \mathrm{BV}$

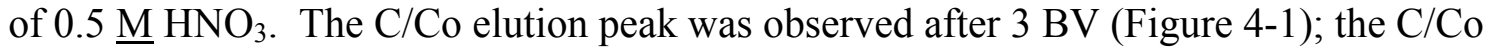
value of 0.01 was reached at $7 \mathrm{BV}$. The results from this shake-down simulant test demonstrated the ion exchange columns were properly functioning to be used for multiple load/elute/ regenerate cycles with the radioactive waste sample.

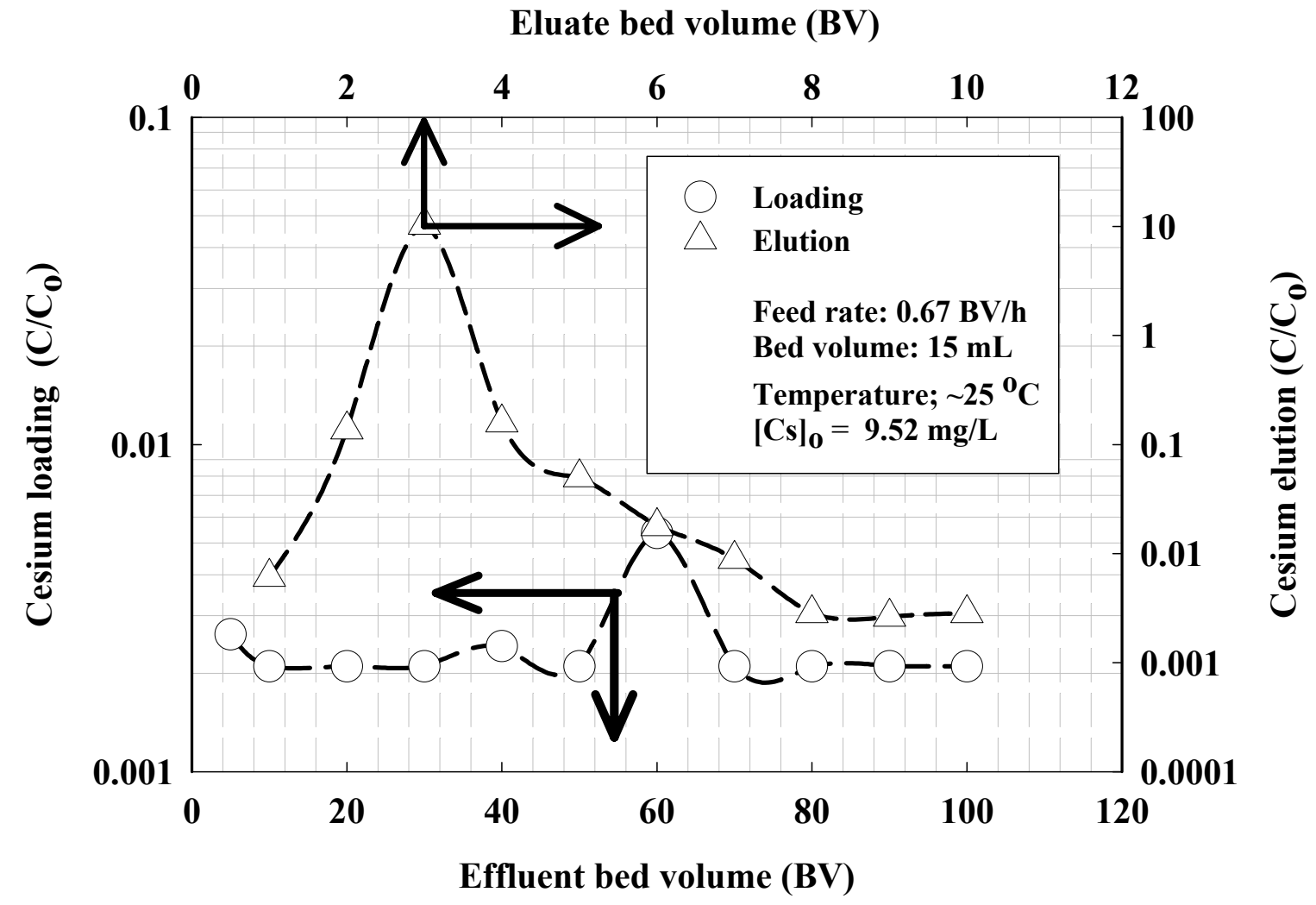

Figure 4-1. Cs Breakthrough and Elution Curves - Simulant 
Figure 4-2 displays the lead column loading and elution data for Re (surrogate for Tc) with AW-101 simulant. The $\mathrm{C} / \mathrm{Co}$ for rhenium was plotted on log scale against the number of BV processed. The $\mathrm{C} / \mathrm{Co}$ was constant (0.012) up to $112 \mathrm{BV}$ of simulant processed, and then it increased linearly on the log scale as the loading progressed. The $\mathrm{C} / \mathrm{Co}$ of 0.1 was observed at $192 \mathrm{BV}$. Rhenium was eluted from the lead and lag columns separately with deionized water at $65{ }^{\circ} \mathrm{C}$ and at a flow rate of $\sim 1 \mathrm{BV} / \mathrm{h}$. The rhenium elution was fast, exhibiting a $\mathrm{C} / \mathrm{Co}$ peak after at $2.5 \mathrm{BV}$. The $\mathrm{C} / \mathrm{Co}$ of 0.01 was reached at $12 \mathrm{BV}$. Since the SuperLig ${ }^{\circledR}$ 639 resin floated earlier in the AW-101 simulant run, the resin beds were restrained with quartz wool and glass beads, thus preventing potential channeling problems. Based on the results from this simulant shake-down test, the ion exchange columns were regarded as being well packed and properly functioning for use with radioactive waste sample.

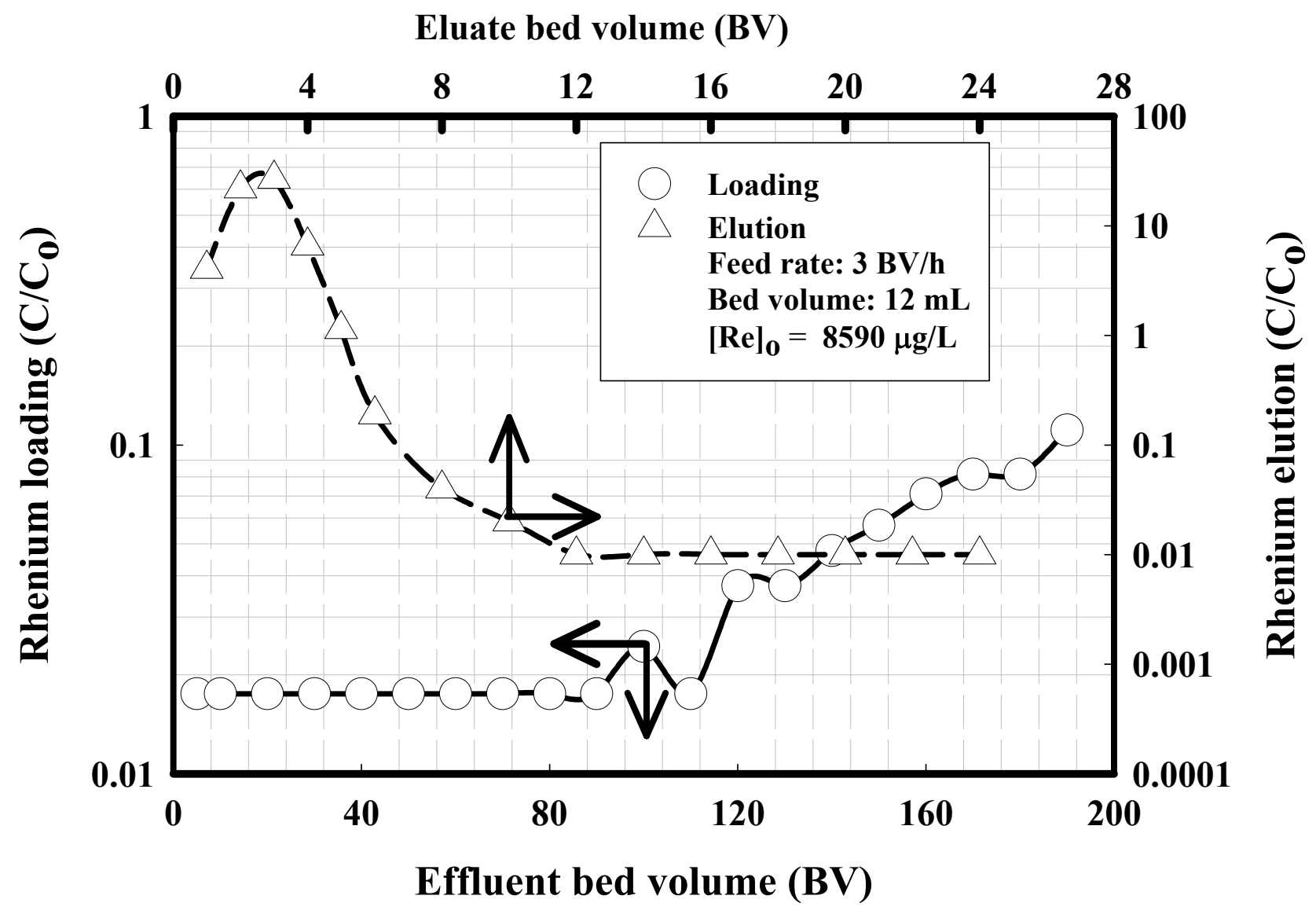

Figure 4-2. Re Breakthrough and Elution Curves - Simulant 


\subsection{CESIUM LOADING CYCLES}

The multiple load/elute/regenerate cycles were carried out in a hot cell using a dual ion exchange column system. Six load cycles were performed to remove ${ }^{137} \mathrm{Cs}$ from AW-101 waste sample. The AW-101 sample at $5 \underline{\mathrm{M} \mathrm{Na}}{ }^{+}$was loaded onto the columns at a flow rate of 0.49-0.69 BV/h. The columns were then washed with $0.1 \mathrm{M} \mathrm{NaOH}$, and rinsed with deionized water. The columns were eluted separately with $0.5 \underline{\mathrm{M}} \mathrm{HNO}_{3}$ at $\sim 1 \mathrm{BV} / \mathrm{h}$ and regenerated with $0.25 \underline{\mathrm{M} \mathrm{NaOH}}$ at $3 \mathrm{BV} / \mathrm{h}$. The ${ }^{137} \mathrm{Cs}$ concentration in the feed (AW-101 filtrate) was $175 \mu \mathrm{Ci} / \mathrm{mL}$.

The ${ }^{137} \mathrm{Cs}$ lead column breakthrough curves for six loading cycles are shown in Figure 4-3; the average flow rates for each cycle appear in the figure. The $\mathrm{C} / \mathrm{Co}$ for ${ }^{137} \mathrm{Cs}$ was plotted as a function of the number of BV processed per cycle. The BV was defined as the volume of the resin bed during the loading. The shape of the breakthrough curves were generally found as expected. The average BV processed at the break point ( $<1 \%$ breakthrough), $10 \%$, and $50 \%$ breakthroughs are reported in Table 4-3. These values were obtained from the breakthrough curves in Figure 4-3. The BVs for cycles \#1, \#3, and \#5 at 50\% breakthrough were extrapolated. The general trend suggests the performance of the resin gradually declined as the loading progressed from cycle \#1 to \#6. Cycle \#4 is not consistent with the other cycles at 10 and $50 \%$ breakthrough levels, where the volume of feed processed is lower than cycles \#5 and \#6. The cause for the lower than expected performance for cycle \#4 at $\mathrm{C} / \mathrm{Co}=0.1$ and 0.5 is not known.

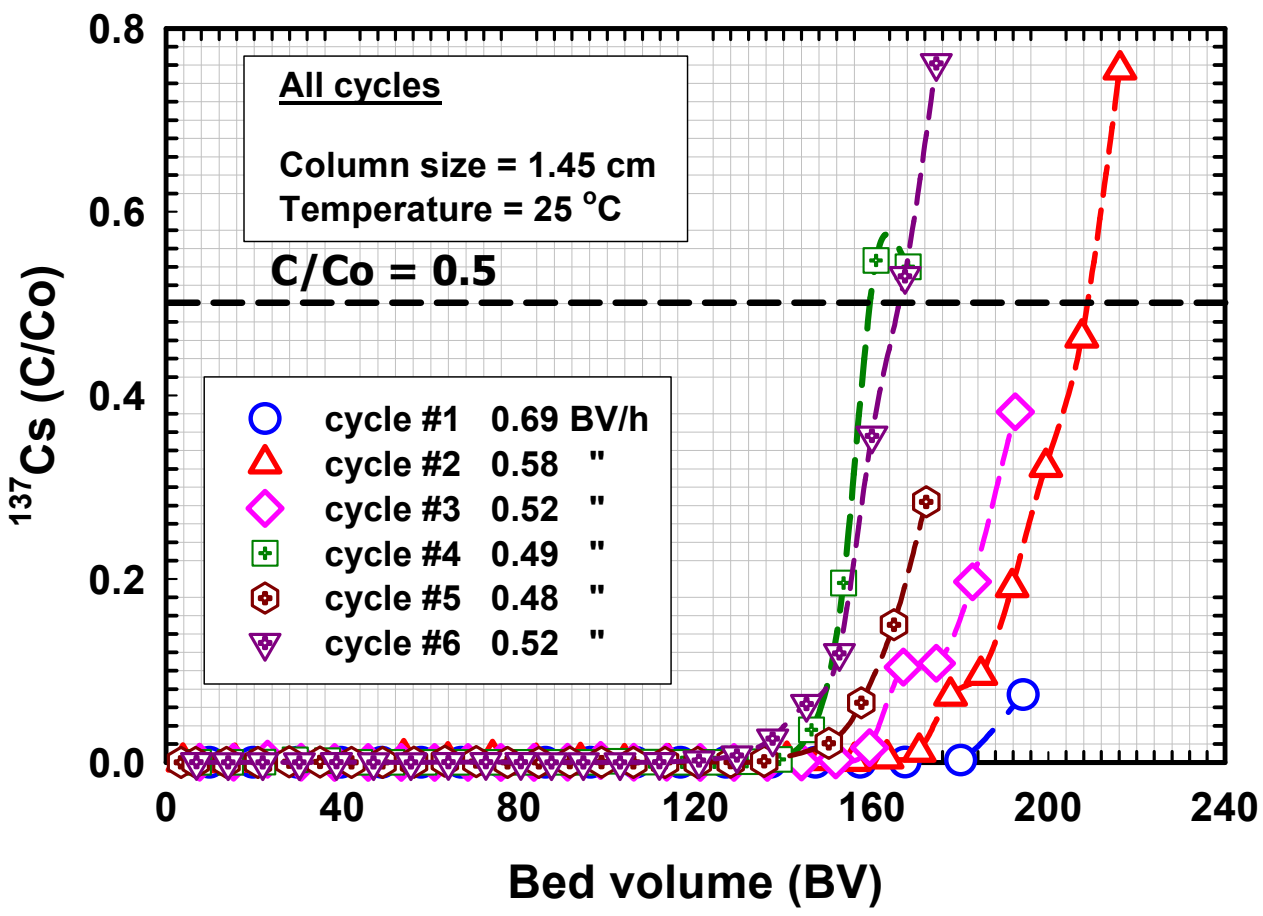

Figure 4-3. ${ }^{137}$ Cs Breakthrough Curves - All Cycles 
WSRC-TR-2003-00098, REVISION 0

SRT-RPP-2003-00026, REVISION 0

Table 4-3. Summary of ${ }^{137}$ Cs loading Performance (BV)

\begin{tabular}{|c|c|c|c|}
\hline Cycle \# & Break point $(<\mathbf{1 \% )}$ & $\mathbf{C / C o}=\mathbf{0 . 1}$ & $\mathbf{C / C o}=\mathbf{0 . 5}$ \\
\hline 1 & 167.5 & 197.5 & 222.4 \\
\hline 2 & 170.7 & 183.0 & 208.6 \\
\hline 3 & 159.5 & 168.9 & 195.8 \\
\hline $\mathbf{4}$ & $\mathbf{1 3 5 . 1}$ & $\mathbf{1 4 6 . 1}$ & $\mathbf{1 5 5 . 6}$ \\
\hline 5 & 135.6 & 161.1 & 180.1 \\
\hline 6 & 120.8 & 147.7 & 166.9 \\
\hline
\end{tabular}

Figure 4-4 shows the results for ${ }^{137} \mathrm{Cs}$ loading in cycle \#1. The ${ }^{137} \mathrm{Cs}$ concentration per mole of $\mathrm{Na}^{+}$was plotted on a log scale as a function of BVs processed through the lead and lag columns. The log scale was chosen to show clearly the several orders of magnitude decrease in the ${ }^{137} \mathrm{Cs}$ concentration and to highlight the loading performance of each cycle in terms of Ci per mole of $\mathrm{Na}^{+}$as specified in the contract. In the interest of those who prefer $\mathrm{C} / \mathrm{Co}$ breakthrough curves, the data are presented in Appendix C. The diamond symbols pertain to individual grab samples collected from the bottom of the lag column; the hexagonal symbols pertain to effluent product solutions or composites of $20 \mathrm{BVs}$ collected also from the lag column.

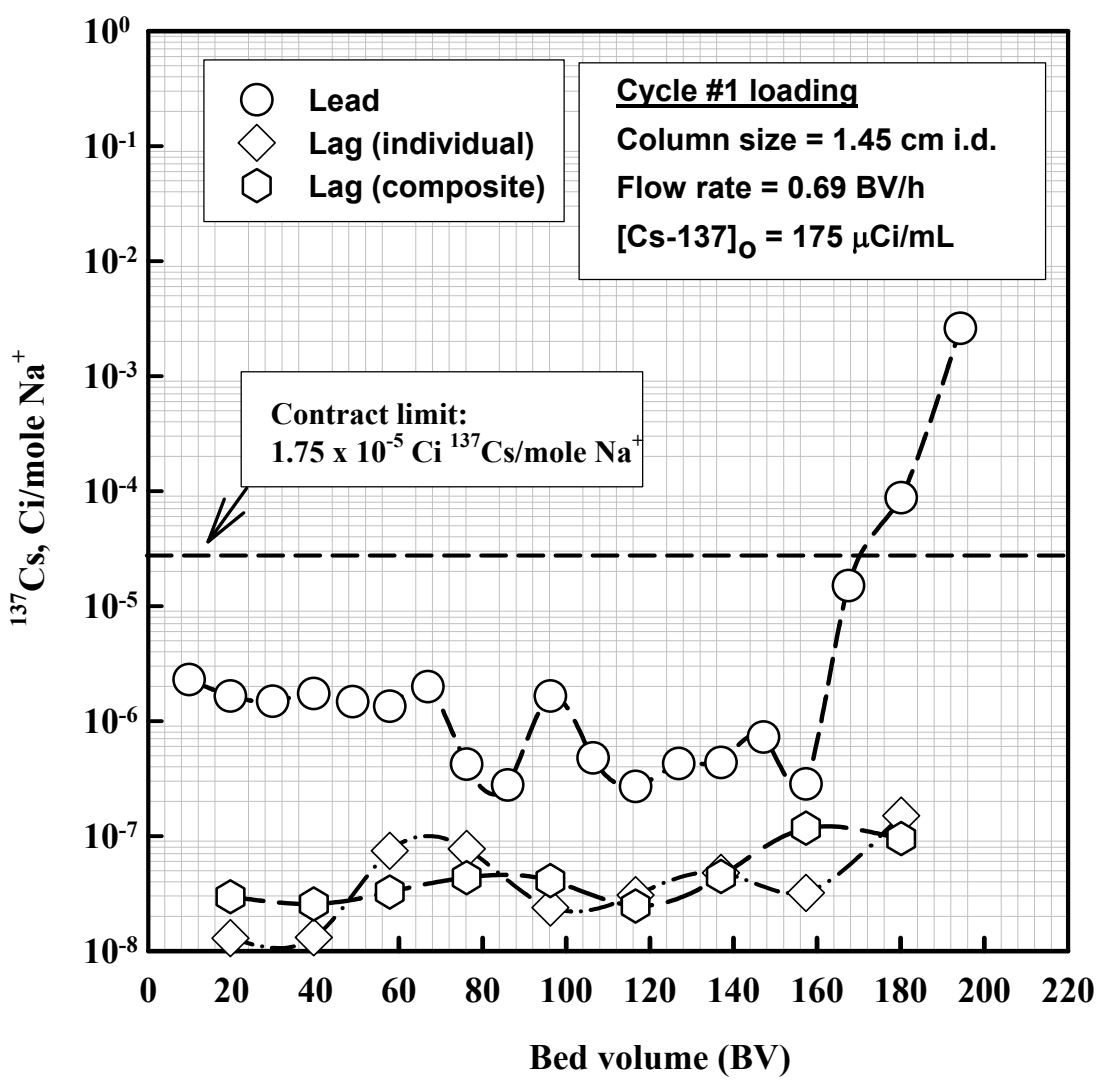

Figure 4-4. ${ }^{137}$ Cs Breakthrough Curves - Cycle \#1 
In Figure 4-4, the ${ }^{137} \mathrm{Cs}$ concentration corresponding to the contract limit of $1.75 \times 10^{-5}$ $\mathrm{Ci} /$ mole $\mathrm{Na}^{+}$is shown as a horizontal dashed line. The $\mathrm{Na}^{+}$concentration in selected effluent samples from the lead column was measured during the run and the average concentration was $4.98 \mathrm{M} \mathrm{Na}^{+}$. This value was used to calculate the concentration exhibited on the $\mathrm{Y}$-axis of Figure 4-4. The $\mathrm{Na}^{+}$concentration in the effluent composite product for cycle \#1 was used to calculate the lag column $\mathrm{Y}$-axis data. The average concentration of $\mathrm{K}^{+}$in effluent samples from the lead and lag columns was 0.49 and $0.44 \underline{\mathrm{M}}$, respectively.

The data show that the concentration of ${ }^{137} \mathrm{Cs}$ per mole of $\mathrm{Na}^{+}$in the lead effluent samples was below $10^{-5}$ until $157 \mathrm{BV}$ of feed was processed. The concentration then increased sharply and crossed the contract limit $\left(1.75 \times 10^{-5} \mathrm{Ci} / \mathrm{mole} \mathrm{Na}^{+}\right)$at $172 \mathrm{BV}$. The ${ }^{137} \mathrm{Cs}$ concentration in the lag column effluent was several orders of magnitude lower than the contract limit. The lag column data displayed in Figure 4-4 include individual samples collected from the bottom of the lag column and effluent composite collected in 20-BV fractions. Approximately $2915 \mathrm{~mL}$ of the AW-101 waste sample at $\sim 5 \underline{\mathrm{M} \mathrm{Na}}{ }^{+}$was processed through the lead column and $2798 \mathrm{~mL}$ of effluent composite product was collected from the lag column. The average concentration of ${ }^{137} \mathrm{Cs}$ in the effluent composite product was $3.0 \mathrm{x}$ $10^{-4} \mu \mathrm{Ci} / \mathrm{mL}$ or $6.0 \times 10^{-8} \mathrm{Ci} / \mathrm{mole} \mathrm{Na}^{+}$which is significantly below the contract limit of $8.07 \times 10^{-2} \mu \mathrm{Ci} / \mathrm{mL}$ or $1.75 \times 10^{-5} \mathrm{Ci} /$ mole Na $^{+}$for $\mathrm{AW}-101$ sample at $5 \underline{\mathrm{M} \mathrm{Na}}{ }^{+}$. The overall performance for cycle \#1 was excellent, exhibiting a DF of $5.8 \times 10^{5}$. The DF was calculated from the initial concentration of ${ }^{137} \mathrm{Cs}$ in the feed and the concentration in the effluent composite product. It should be noted that the flow rate employed in this test $(0.69 \mathrm{BV} / \mathrm{h})$ was significantly below the nominal design flow rate of $3 \mathrm{BV} / \mathrm{h}$. Therefore, the column loading results and the overall performance indicated for the test do not fully mimic the WTP plant conditions.

Figure 4-5 shows the ${ }^{137} \mathrm{Cs}$ loading data in cycle \# 2. The initial loading performance of the lead column was very poor. The ${ }^{137} \mathrm{Cs}$ concentration in effluent samples collected up to 160 BV was at or above the contract limit. The reason for the initial poor performance was due to the fact that the lead column was re-packed after cycle \#1 was completed. When the lead column regeneration for cycle \#2 started, the liquid head above the resin bed suddenly dropped to less than $2 \mathrm{~cm}$ above the resin. In order to restore the liquid head, several BV of $0.25 \mathrm{M} \mathrm{NaOH}$ was pumped as up flow through the column. The column re-packing could possibly have resulted in channeling during the early stages of loading. The ${ }^{137} \mathrm{Cs}$ concentration increased linearly after $160 \mathrm{BV}$ as shown by the log curve on the Y-axis (Figure 4-5). The $\mathrm{Na}^{+}$concentration used for $\mathrm{Y}$-axis calculation was $5.06 \underline{\mathrm{M}}$; it was determined from ICP-AES measurements of eight effluent samples from the lead column. The average concentration of $\mathrm{K}^{+}$was $0.52 \underline{\mathrm{M}}$. The loading performance of the lag column was excellent, exhibiting a ${ }^{137} \mathrm{Cs}$ concentration $<10^{-6} \mathrm{Ci} / \mathrm{mole}$ of $\mathrm{Na}^{+}$at $190 \mathrm{BV}$. The concentration of $\mathrm{K}^{+}$in the effluent composite product was $0.42 \underline{\mathrm{M}}$. 


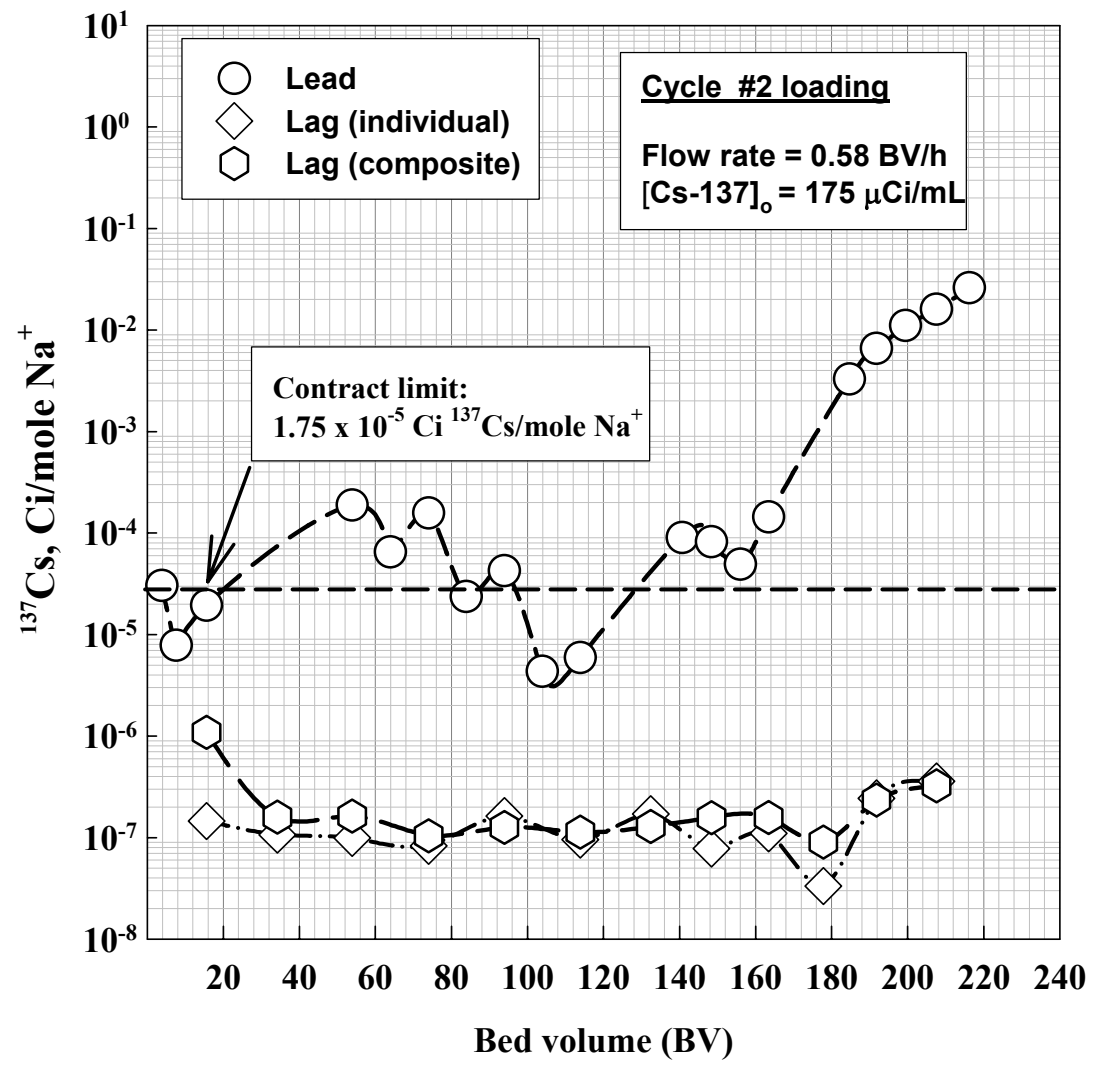

Figure 4-5. ${ }^{137}$ Cs Breakthrough Curves - Cycle \# 2

Figure 4-6 shows the loading data for ${ }^{137} \mathrm{Cs}$ in cycle \#3. The concentration of ${ }^{137} \mathrm{Cs}$ in lead column effluent samples crossed the contract limit of $1.75 \times 10^{-5} \mathrm{Ci} / \mathrm{mole} \mathrm{Na}^{+}$after processing $142 \mathrm{BV}$. The concentration then increased linearly on the log scale, which indicates the onset of breakthrough. The concentration of $\mathrm{Na}^{+}$used in the $\mathrm{Y}$-axis calculation was $4.5 \mathrm{M}$; it was determined from measurement of six effluent samples (lead column) by atomic absorption (AA). The performance of the lag column was excellent, exhibiting ${ }^{137} \mathrm{Cs}$ concentration significantly below $10^{-5} \mathrm{Ci} /$ mole $\mathrm{Na}^{+}$in effluent samples. The $\mathrm{Na}^{+}$ concentration in the effluent composite product of cycle \#3 (5.22 $\mathrm{M})$ was used to calculate the $\mathrm{Y}$-axis lag column data. The ${ }^{137} \mathrm{Cs}$ concentration of the last sample from the lag column (see last data point) was sharply lower than expected. It is suspected that the sample was diluted by $0.1 \mathrm{M} \mathrm{NaOH}$ feed displacement solution when the sample was collected. Although the overall performance of column was outstanding in cycle \#3, it should be recognized that the flow rate produced these results does not mimic the WTP design flow rate. The reason for the deviation from the WTP plant design flow rate was to increase the dose to resin, which could only be achieved by processing the feed solution at very low flow rate. 


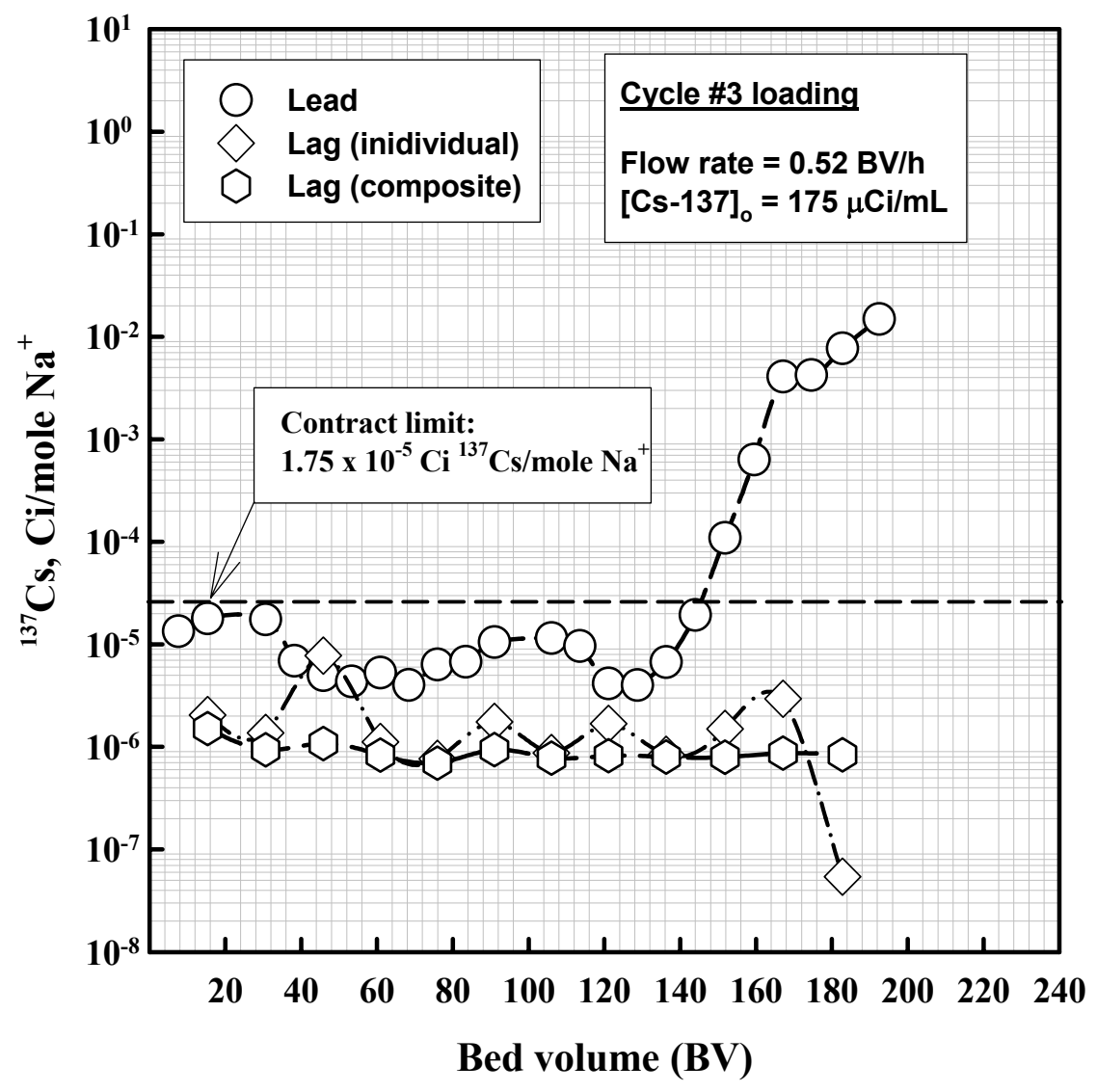

Figure 4-6. ${ }^{137}$ Cs Breakthrough Curves - Cycle \# 3

The ${ }^{137} \mathrm{Cs}$ loading data for cycle \#4 are shown in Figure 4-7. The initial performance of the lead column was very good; exhibiting a cesium concentration below $10^{-5} \mathrm{Ci} / \mathrm{mole} \mathrm{Na}^{+}$until $120 \mathrm{BV}$ of the AW-101 sample was processed. The concentration increased linearly on the $\log$ scale and crossed the contract limit of $1.75 \times 10^{-5} \mathrm{Ci}^{137} \mathrm{Cs} / \mathrm{mole} \mathrm{Na}^{+}$at $128 \mathrm{BV}$. The decline in ${ }^{137} \mathrm{Cs}$ concentration after $160 \mathrm{BV}$ was not expected and the cause is not known. The $\mathrm{Na}^{+}$concentration $(4.3 \mathrm{M})$ used in $\mathrm{Y}$-axis calculation was determined from the measurement of four individual lead column effluent samples by ICP-AES. The average concentration of $\mathrm{K}^{+}$in these samples was $0.50 \mathrm{M}$. 


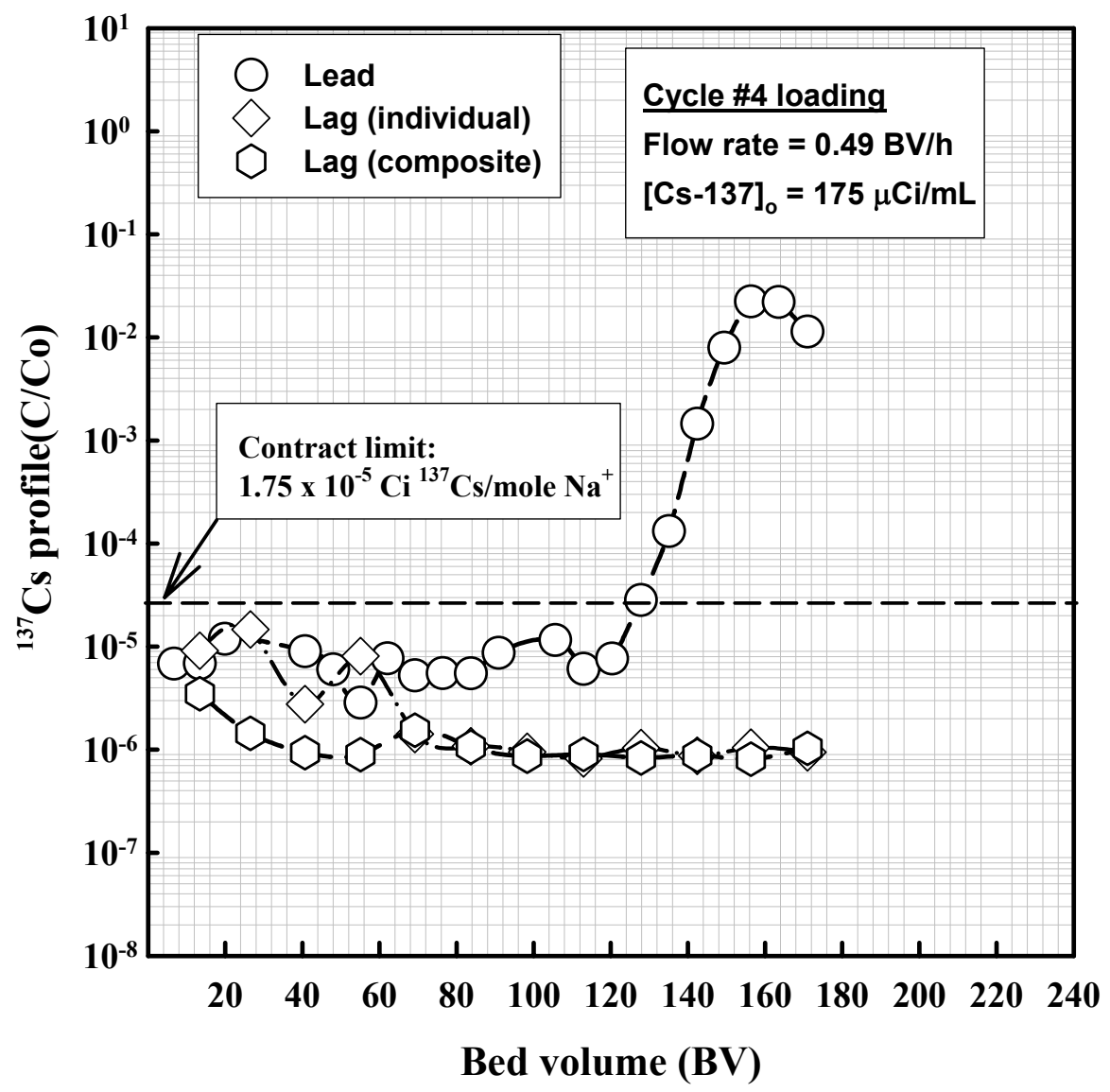

Figure 4-7. ${ }^{137}$ Cs Breakthrough Curves - Cycle \# 4

Although the initial performance of the lag column (up to $70 \mathrm{BV}$ ) was poor compared to previous 3 cycles, the ${ }^{137} \mathrm{Cs}$ concentration in effluent samples was below the contract limit. The reason for the initial poor performance of the lag column could be incomplete resin conditioning or cesium bleed from the resin. The ${ }^{137} \mathrm{Cs}$ concentration was at $\sim 10^{-6} \mathrm{Ci}$ ${ }^{137} \mathrm{Cs} /$ mole Na after processing $70 \mathrm{BV}$. The ${ }^{137} \mathrm{Cs}$ concentration in the effluent composite samples from the lag column was $5.4 \times 10^{-3} \mu \mathrm{Ci} / \mathrm{mL}$. The overall $\mathrm{DF}$ for ${ }^{137} \mathrm{Cs}\left(3.3 \times 10^{4}\right)$ was calculated from feed and effluent composite product concentrations. 
Figure 4-8 displays the results of ${ }^{137} \mathrm{Cs}$ loading data for cycle \# 5 . The scatter of the lead column data was significant until $120 \mathrm{BV}$ of sample was processed. The scatter was caused by inadequate flushing of the auto-sampler lines at the end of elution step in cycle \# 4 . The ${ }^{137}$ Cs peak samples were collected in sampling lines \#4, \#5 and \#6 and later flushed with DI water. However, the flush samples were not analyzed to determine residual cesium concentration. When cycle \#5 loading started, the lead column effluent samples collected from sampling lines \#4 \#5, and \#6 were contaminated with residual Cs from the elution. As a result, the cesium concentration of several effluent samples exceeded the contract limit. In Figure 4-8, the ${ }^{137} \mathrm{Cs}$ concentration increased linearly on the log scale after processing 120 $\mathrm{BV}$ and it crossed the contract limit at $128 \mathrm{BV}$. A concentration of $4.78 \mathrm{M}$ for $\mathrm{Na}^{+}$was used in the $\mathrm{Y}$-axis calculation. The concentration of $\mathrm{K}^{+}$in the effluent samples was $0.51 \underline{\mathrm{M}}$. The lag column performance was good, exhibiting cesium concentration below the contract limit during the entire column loading. The average ${ }^{137} \mathrm{Cs}$ concentration in the composite lag column samples was $4.01 \times 10^{-3} \mu \mathrm{Ci} / \mathrm{mL}$, which calculates an overall DF of $4.4 \times 10^{4}$ for cycle $\# 5$.

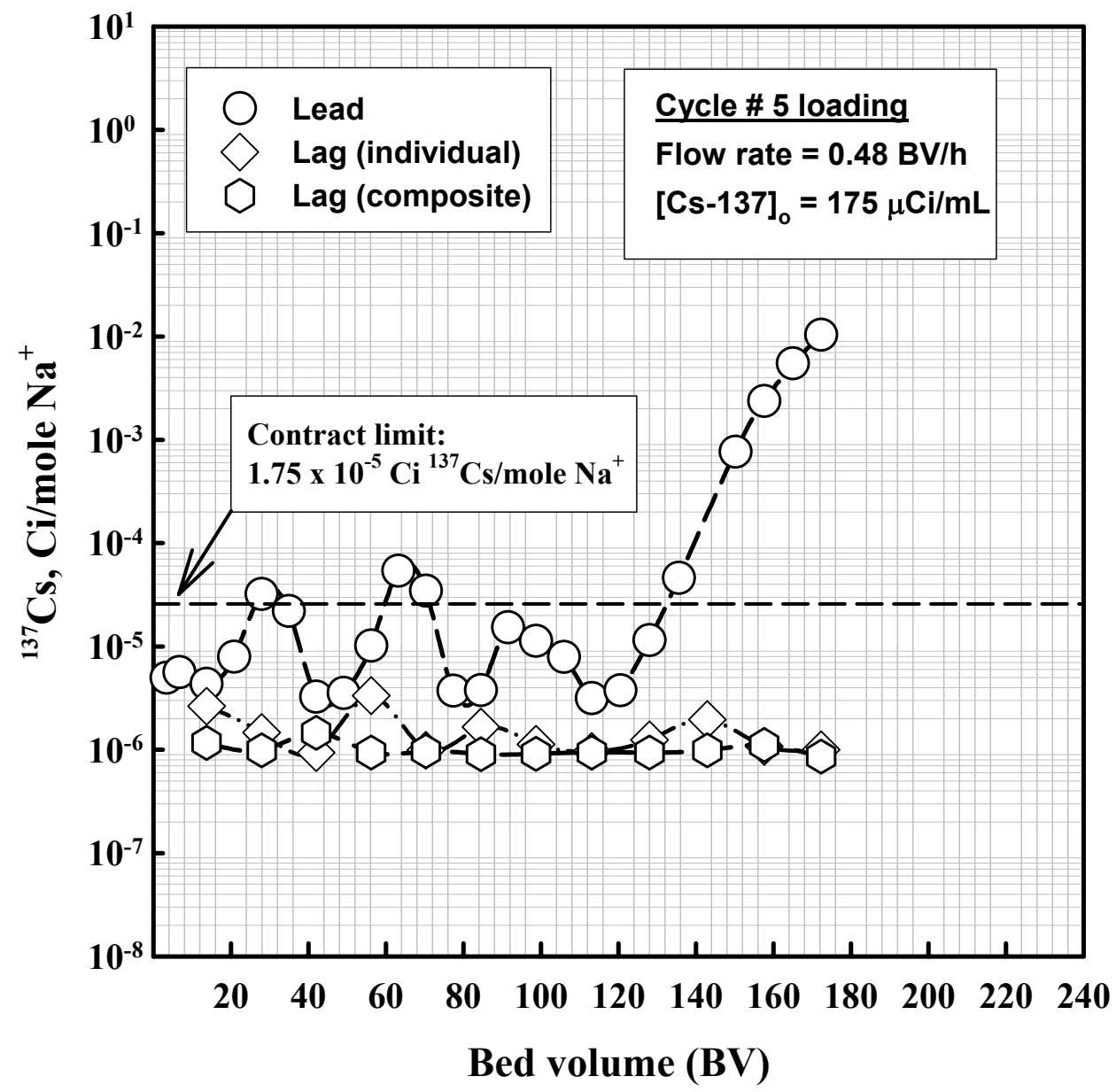

Figure 4-8. ${ }^{137}$ Cs Breakthrough Curves - Cycle \# 5 
Figure 4-9 shows the loading data in cycle \# 6. The loading performance of lead column deteriorated significantly as compared to cycle $\# 1$. The ${ }^{137} \mathrm{Cs}$ concentration per mole $\mathrm{Na}^{+}$ was constant (horizontally flat) near the contract limit until $100 \mathrm{BV}$ was processed. The concentration crossed the contract limit permanently at $112 \mathrm{BV}$. The start breakthrough corresponds to beginning of linear increase of cesium concentration on log scale. The concentration of $\mathrm{Na}^{+}$used to calculate the $\mathrm{Y}$-axis data was determined from ICP-AES measurement of five lead column effluent samples. The average value of $3.7 \underline{\mathrm{M}}$ was lower than expected; the average concentration of $\mathrm{K}^{+}$in the lead column effluent samples was $0.43 \mathrm{M}$. The cause for the low concentration of $\mathrm{Na}^{+}$in the effluent samples is not identified. The performance of the lag column was very good. The ${ }^{137} \mathrm{Cs}$ concentration in lag column composite fractions was below the contract limit of $1.75 \times 10^{-5} \mathrm{Ci} / \mathrm{mole} \mathrm{Na}^{+}$during the entire loading period. The average ${ }^{137} \mathrm{Cs}$ concentration in lag column effluent composite fractions was $4 \times 10^{-3} \mu \mathrm{Ci} / \mathrm{mL}$, which corresponds to overall DF of $4.4 \times 10^{4}$.

Table 4-4 shows a summary of column loading capacity, dose to resin for each cycle, and the total dose to resin during six loading cycles. The column loading capacity was calculated from the breakthrough curve at the breakpoint (i.e., onset of Cs breakthrough), at 10 and 50\% breakthrough. The dose to the ion exchange resin bed was calculated using the commercial code MicroShield (v. 5.03) software. ${ }^{20}$ The beta decay provides the majority of the radiation dose and because beta particles have a very short range they deposit all their energy in a small volume around the point at which the decay takes place. The gamma rays on the other hand have a long range, which will normally escape due to small size of the column. The dose to resin was determined from the radioactivity $\left(\mathrm{Ci}\right.$ of ${ }^{137} \mathrm{Cs}$ ) loaded in each cycle, the flow rate, and the time to load the column. Details of the dose to resin calculations are given in Appendix F.

Table 4-5 shows a summary of the swelling and shrinking history of lead column during loading, feed displacement $(0.1 \underline{\mathrm{M} \mathrm{NaOH}})$, elution $\left(0.5 \underline{\mathrm{M}} \mathrm{HNO}_{3}\right)$, and regeneration $(0.25 \underline{\mathrm{M}}$ $\mathrm{NaOH})$. When the SuperLig ${ }^{\circledR} 644$ resin was first slurred into the columns with DI water, the volume of the resin bed in the lead column was $8.3 \mathrm{~mL}$ (i.e. $5-\mathrm{cm}$ resin bed height in $1.45-\mathrm{cm}$ diameter glass column). The lag column contained $7.25 \mathrm{~mL}$ of resin in DI water. After passing $12 \mathrm{BV}$ of $0.25 \mathrm{M} \mathrm{NaOH}$ through each resin bed and allowing it to soak overnight, the volumes of fully swollen bed in the lead was $14.8 \mathrm{~mL}$. The volume of resin bed during loading, elution, and regeneration were calculated from recorded height of the resin bed during six loading cycles. The average BV volume during loading, feed displacement, elution, and regeneration for all six cycles was $\sim 14.8,15.8,11.7$, and $15 \mathrm{ml}$, respectively. 


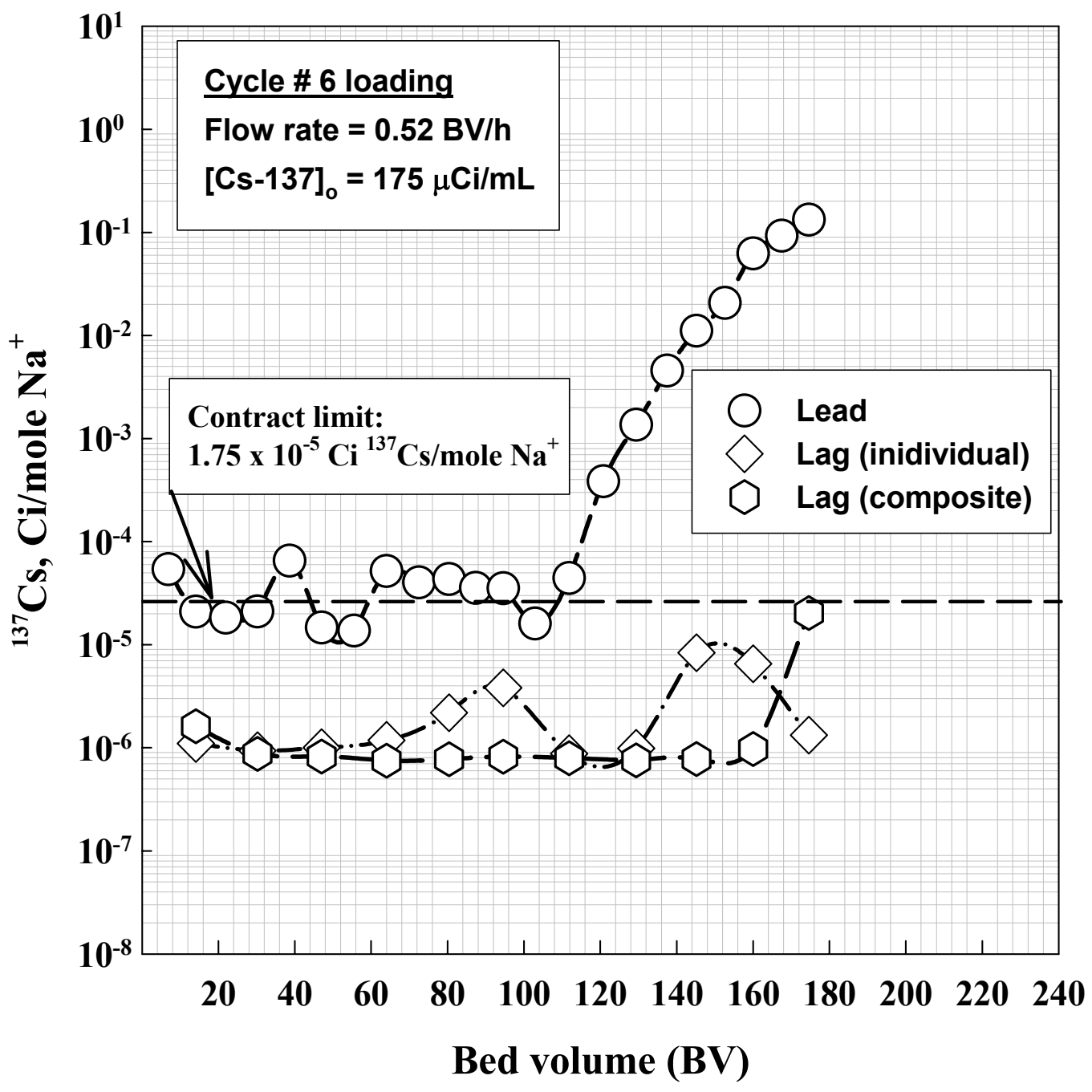

Figure 4-9. ${ }^{137}$ Cs Breakthrough Curves for - Cycle \#6

Table 4-4. Summary of ${ }^{137}$ Cs Column Dose and Loading Capacity

\begin{tabular}{|c|l|l|l|l|c|}
\hline Cycle \# & $\begin{array}{l}\text { Dose/cycle } \\
\text { (Rad) }\end{array}$ & $\begin{array}{l}\text { Total dose } \\
\text { (Rad) }\end{array}$ & $\begin{array}{l}\text { Break point } \\
\text { (mmole/g) }\end{array}$ & $\begin{array}{l}\text { C/Co= 0.1 } \\
\text { (mmole/g) }\end{array}$ & $\begin{array}{l}\text { C/Co=0.5 } \\
\text { (mmole/g) }\end{array}$ \\
\hline 1 & $2.60 \mathrm{E}+06$ & $2.60 \mathrm{E}+06$ & $1.26 \mathrm{E}-02$ & $1.41 \mathrm{E}-02$ & $*$ \\
\hline 2 & $4.24 \mathrm{E}+06$ & $6.84 \mathrm{E}+06$ & $1.16 \mathrm{E}-02$ & $1.31 \mathrm{E}-02$ & $1.42 \mathrm{E}-02$ \\
\hline 3 & $3.57 \mathrm{E}+06$ & $1.04 \mathrm{E}+07$ & $1.08 \mathrm{E}-02$ & $1.18 \mathrm{E}-02$ & $1.34 \mathrm{E}-02$ \\
\hline 4 & $3.24 \mathrm{E}+06$ & $1.36 \mathrm{E}+07$ & $9.69 \mathrm{E}-03$ & $1.04 \mathrm{E}-02$ & $1.08 \mathrm{E}-02$ \\
\hline 5 & $2.98 \mathrm{E}+06$ & $1.66 \mathrm{E}+07$ & $9.76 \mathrm{E}-03$ & $1.15 \mathrm{E}-02$ & $1.24 \mathrm{E}-02$ \\
\hline 6 & $3.30 \mathrm{E}+06$ & $1.99 \mathrm{E}+07$ & $8.70 \mathrm{E}-03$ & $1.07 \mathrm{E}-02$ & $1.14 \mathrm{E}-02$ \\
\hline
\end{tabular}

* = not estimated 
Thus, the percent volume change of the resin bed in the lead column between elution and regeneration was $\sim 22 \%$. During column loading and elution, the resin bed swells and shrinks. Swelling is often observed when the resin converts between sodium and hydrogen forms. Generally, some swelling of the resin is desirable for the ion exchange process to take place. A swollen resin allows faster mass transfer by reducing intra-particle resistance. Resin swelling and shrinking, however, can become undesirable from operations point of view since excessive swelling could potentially cause hydraulic problems and channeling. The swelling and shrinking behavior of this resin batch was essentially invariant with superficial velocity under the present experimental conditions.

Table 4-5. Resin Bed Swelling and Shrinking History for Lead Column

\begin{tabular}{|c|c|c|c|c|c|}
\hline & \multirow{2}{*}{ Flow rate } & $\mathbf{5} \mathbf{M}_{\mathbf{~ N a}}^{+}$ & \multicolumn{3}{|c|}{ Volume of resin bed (mL) } \\
\cline { 4 - 6 } & $\mathbf{( B V / h )}$ & $\mathbf{A} \overline{\mathbf{W}}-\mathbf{1 0 1}$ & $\mathbf{0 . 1} \underline{\mathbf{M}} \mathbf{~ N a O H}$ & $\mathbf{0 . 5} \underline{\mathbf{M}} \mathbf{H N O 3}$ & $\mathbf{0 . 2 5} \underline{\mathbf{M}} \mathbf{~ N a O H}$ \\
\hline 1 & 0.69 & 14.9 & 15.0 & 11.7 & 14.9 \\
\hline 2 & 0.59 & 14.7 & 15.7 & 11.2 & 14.4 \\
\hline 3 & 0.52 & 14.7 & 15.7 & 12.2 & 15.2 \\
\hline 4 & 0.49 & 14.9 & 16.2 & 11.9 & 16.0 \\
\hline 5 & 0.49 & 14.9 & 16.0 & 11.4 & 14.4 \\
\hline 6 & 0.52 & 14.5 & 16.2 & 11.9 & $\mathrm{~nm}$ \\
\hline
\end{tabular}

$\mathrm{nm}=$ not measured

\subsection{CESIUM ELUTION CYCLES}

Following each loading cycle, the lead and lag columns were eluted separately. Elution was generally performed immediately after feed displacement with $0.1 \underline{\mathrm{M} \mathrm{NaOH}}$ and DI water rinse steps were completed. The ${ }^{137} \mathrm{Cs}$ was eluted from the ion exchange columns using

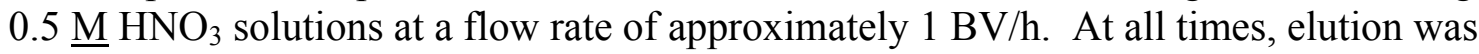
carried out downward using a separate pump from that employed during the column loading. While the lead and lag columns were both eluted, data on elution profile were collected only on the lead column.

Figure 4-10 displays the $\mathrm{C} / \mathrm{Co}$ for ${ }^{137} \mathrm{Cs}$ in lead column eluate samples for cycle \#1. The $\mathrm{C} / \mathrm{Co}$ was plotted on a logarithmic scale against the eluate $\mathrm{BV}$ that passed through the column. The elution was performed at a flow rate of $0.63 \mathrm{BV} / \mathrm{h}$ based on average resin bed volume of $10.9 \mathrm{~mL}$ from the start to the end of elution. The target flow rate for elution runs was $1 \mathrm{BV} / \mathrm{h}$. The ${ }^{137} \mathrm{Cs}$ peak was exhibited in less than $2 \mathrm{BV}$ with $\mathrm{C} / \mathrm{Co}$ value of 46 . The $\mathrm{C} / \mathrm{Co}$ gradually declined after the peak, reaching a target $\mathrm{C} / \mathrm{Co}$ of 0.01 after $8 \mathrm{BVs}$. The ${ }^{137} \mathrm{Cs}$ concentration in the composite eluate solution was $1.73 \times 10^{3} \mu \mathrm{Ci} / \mathrm{mL}$. The composite eluate volume collected during elution was $141.5 \mathrm{~mL}$. This was diluted by a minimum $2 \mathrm{BV}$ of deionized water in the column headspace. Thus, the total ${ }^{137} \mathrm{Cs}$ recovered in the eluate was $2.4 \times 10^{5} \mu \mathrm{Ci}$ (i.e. $1730 * 141.5$ ). The total ${ }^{137} \mathrm{Cs}$ loaded on the resin in the lead column was approximately $5 \times 10^{5} \mu \mathrm{Ci}$, which suggests that a significant amount of the Cs was not accounted in the eluate. 


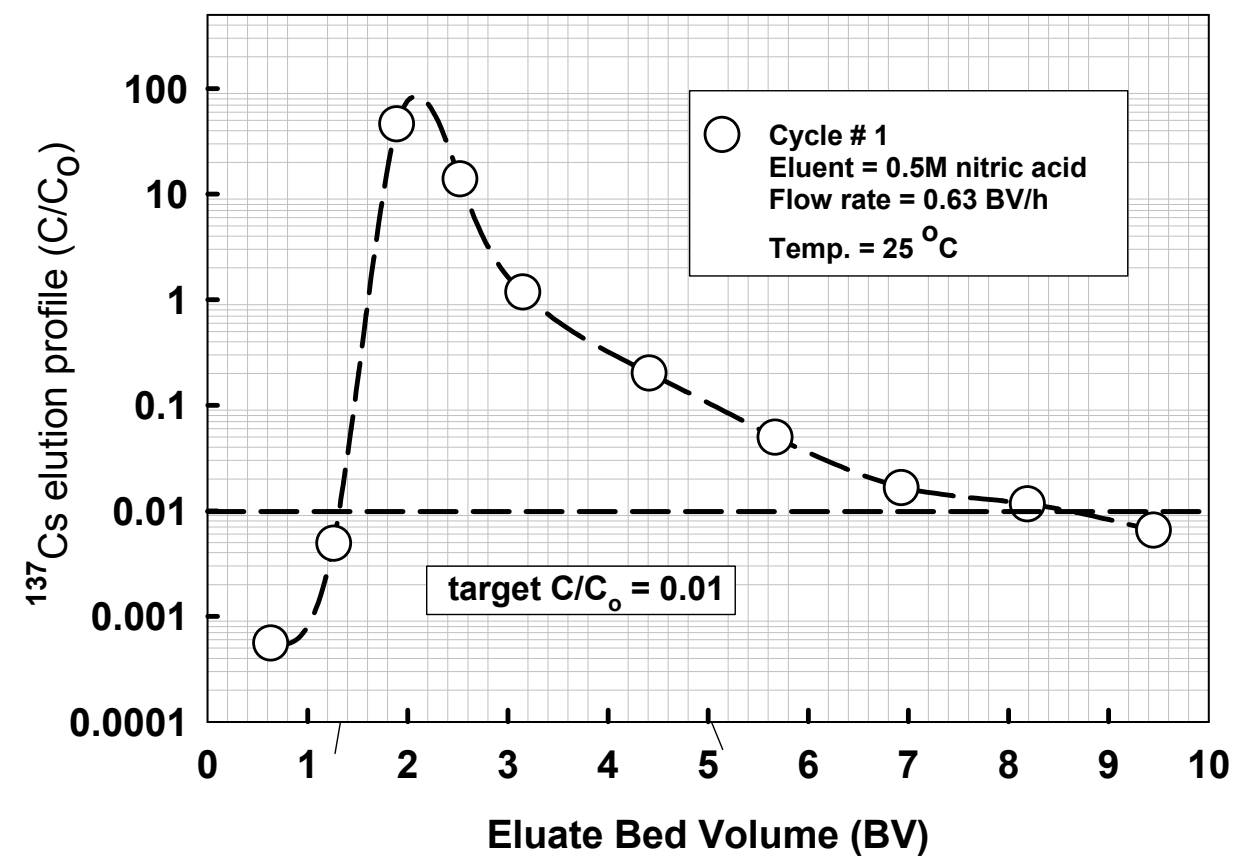

Figure 4-10. ${ }^{137}$ Cs Elution Curve- Cycle \#1

Figure 4-11 shows the concentrations of $\mathrm{Na}^{+}$and $\mathrm{K}^{+}$in the eluate as function of the eluate $\mathrm{BV}$. The $\mathrm{K}^{+}$and $\mathrm{Na}^{+}$exhibited maximum concentration at about $1.5 \mathrm{BV}$, which coincided with the ${ }^{137} \mathrm{Cs} \mathrm{C} / \mathrm{Co}$ peak elution. Generally, hydronium ions $\left(\mathrm{H}^{+}\right)$are removed from the $0.5 \underline{\mathrm{M}} \mathrm{HNO} 3$ solution passing through the resin bed and exchanged with equivalent number of moles with of Cs, $\mathrm{K}^{+}$, and $\mathrm{Na}^{+}$ions on the resin. Since most RPP-WTP studies have not measured $\mathrm{K}^{+}$and $\mathrm{Na}^{+}$ions in the eluate samples, elution peaks for these ions were not identified and their significance has yet to be understood. In this cycle, we note that both $\mathrm{K}^{+}$ and $\mathrm{Na}^{+}$ions exhibited elution peak at $2 \mathrm{BV}$, which corresponds to that of $\mathrm{Cs}^{+}$. In addition, $\mathrm{Na}^{+}$exhibited a second hump at $5 \mathrm{BV}$. The significance of this hump is not clear.

Figure 4-12 shows the $\mathrm{C} / \mathrm{Co}$ for ${ }^{137} \mathrm{Cs}$ plotted on logarithmic scale as a function of eluate $\mathrm{BV}$ (for cycle 2) to show the large range of $\mathrm{C} / \mathrm{Co}$ values. The flow rate during the elution was $1.05 \mathrm{BV} / \mathrm{h}$ (based on average elution volume). The peak $\mathrm{C} / \mathrm{Co}$ for ${ }^{137} \mathrm{Cs}$ was observed at about $3 \mathrm{BV}$, but the value was just 31 times the feed concentration. The $\mathrm{C} / \mathrm{Co}$ of 0.01 was reached after $12 \mathrm{BV}$ of the eluent passed through the column. The ${ }^{137} \mathrm{Cs}$ concentration in the composite eluate solution was $2.19 \times 10^{3} \mu \mathrm{Ci} / \mathrm{mL}$. The composite eluate volume collected during elution was about $220 \mathrm{~mL}$. Thus, the total ${ }^{137} \mathrm{Cs}$ recovered in the eluate solution was $4.8 \times 10^{5} \mu \mathrm{Ci}$.

The ${ }^{137} \mathrm{Cs}$ in post-elution rinse and regeneration data are also shown in Figure 4-12. The $\mathrm{C} / \mathrm{Co}$ increased during the first $2 \mathrm{BV}$ to a value of 0.49 and then steeply declined to $\sim 0.003$ of its value in the feed sample. The trend of the ${ }^{137} \mathrm{Cs}$ profile during regeneration was similar to that of the post-elution DI water rinse. The reason for the $\mathrm{C} / \mathrm{Co}$ increase in the post elution rinse water is not known, but similar observations has been previously reported. ${ }^{(21)}$ 


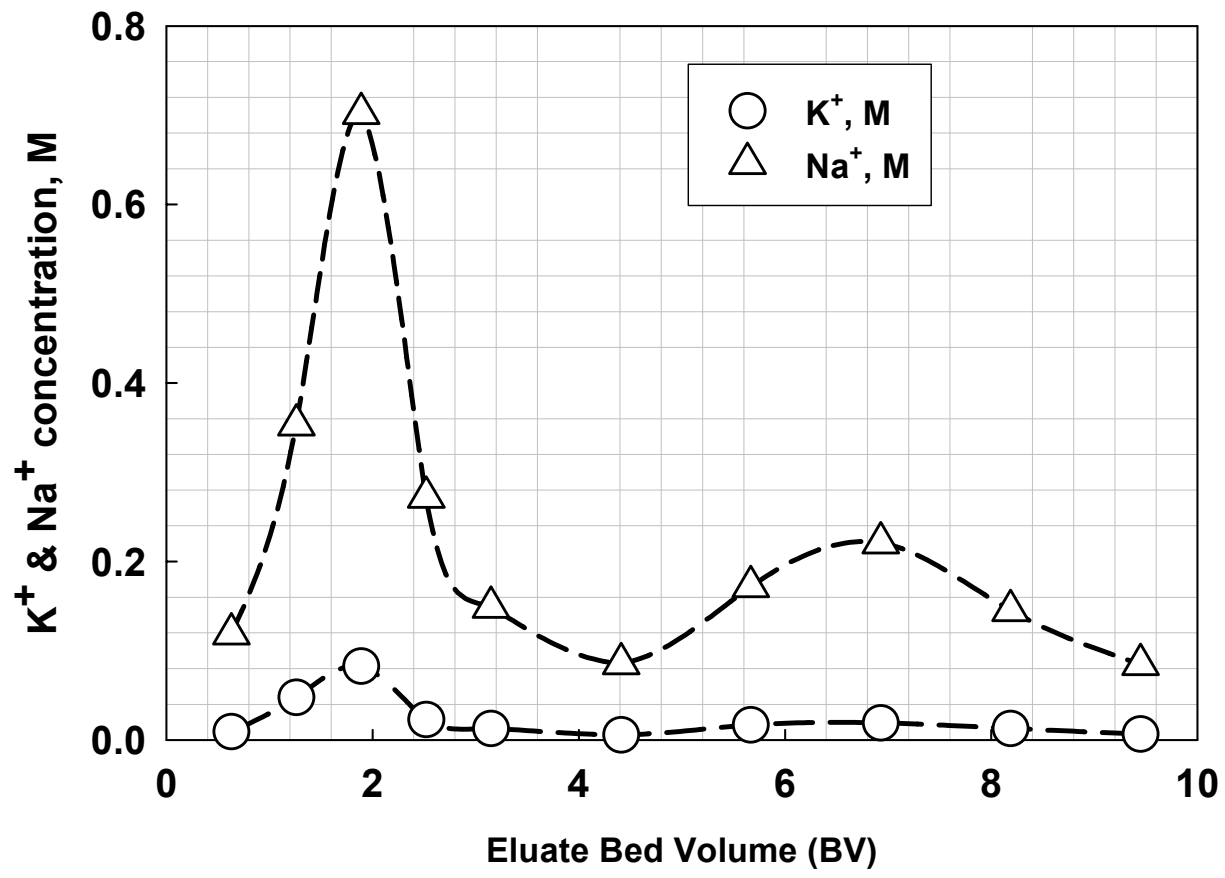

Figure 4-11. $\mathrm{Na}^{+}$and $\mathrm{K}^{+}$in Eluate samples - Cycle \#1

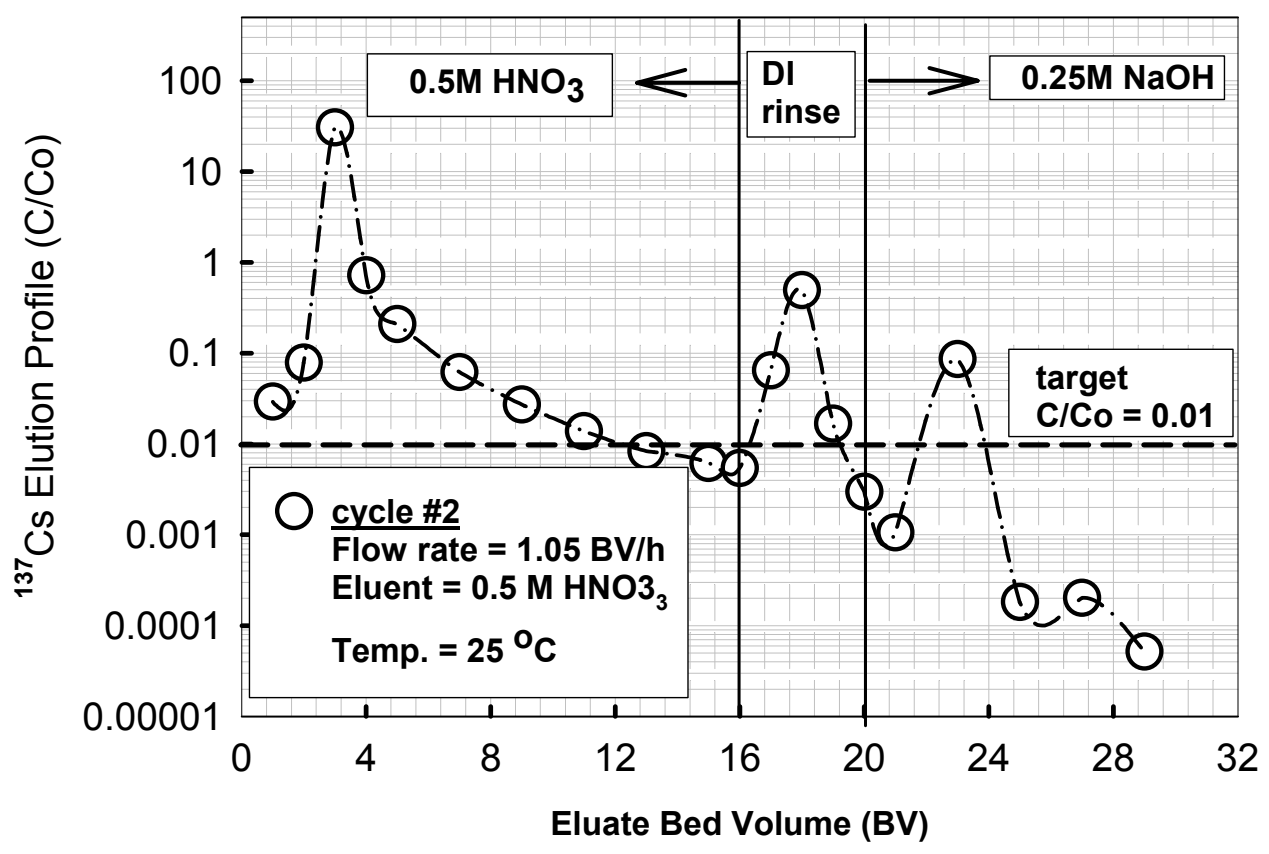

Figure 4-12. ${ }^{137}$ Cs Elution Curve - Cycle \#2 
Figure 4-13 displays the ${ }^{137} \mathrm{Cs}$ elution for cycle \#3. Elution flow rate was $\sim 1.01 \mathrm{BV} / \mathrm{h}$, based on average elution bed volume of $11.7 \mathrm{~mL}$. The $\mathrm{C} / \mathrm{Co}$ peak for ${ }^{137} \mathrm{Cs}$ was exhibited at $4 \mathrm{BV}$ with a value was 56 times its feed concentration. The $\mathrm{C} / \mathrm{Co}$ reached 0.01 after $9 \mathrm{BV}$ of eluent passed through the column. The ${ }^{137} \mathrm{Cs}$ concentration in the composite eluate solution was approximately $2.1 \times 10^{3} \mu \mathrm{Ci} / \mathrm{mL}$ and the eluate composite volume collected during the elution was $186 \mathrm{~mL}$. The $\mathrm{Na}^{+}$concentration in the eluate samples was measured and the average value of $1.87 \underline{\mathrm{M}}$ was higher than would be expected during elution.

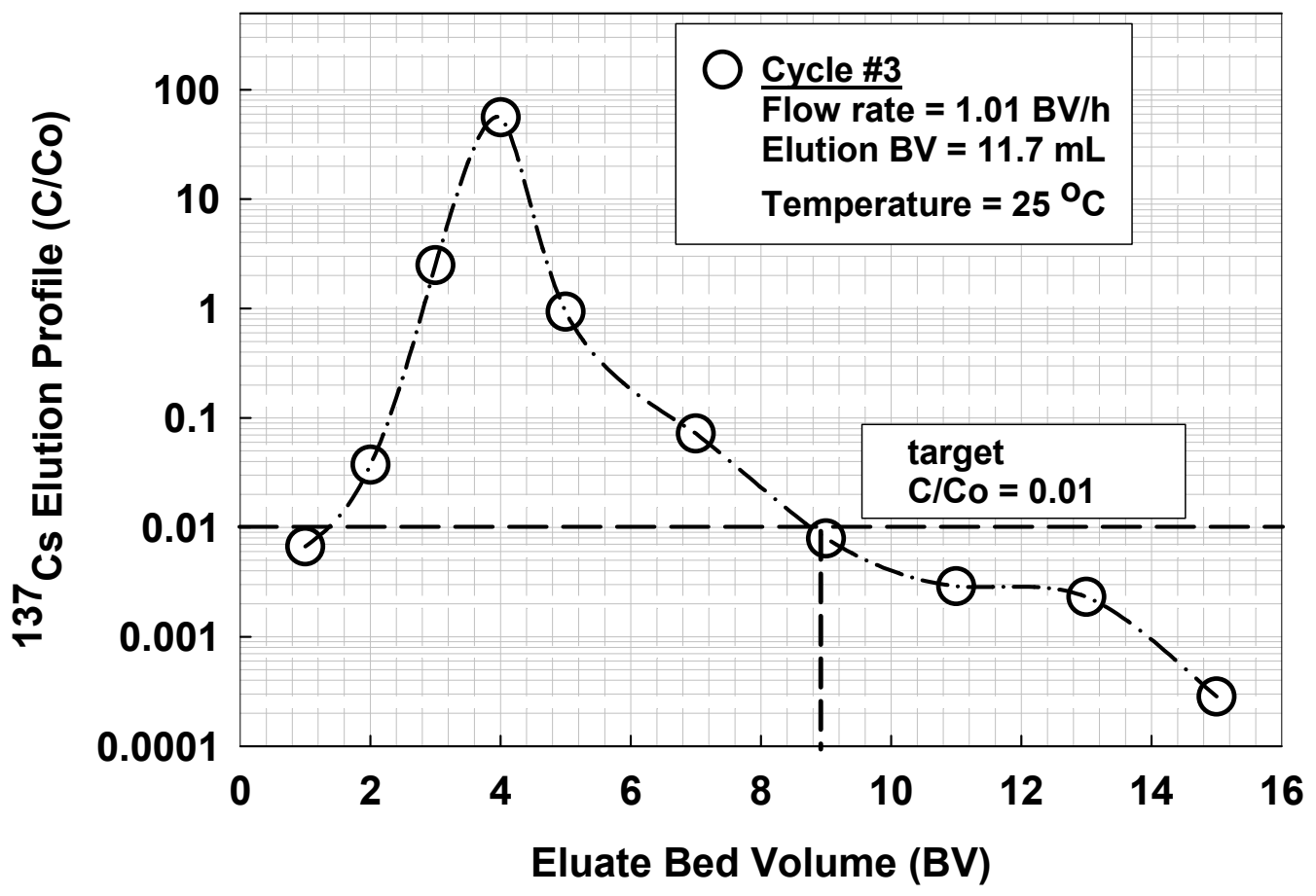

Figure 4-13. ${ }^{137}$ Cs Elution Curve - Cycle \#3

Figure 4-14 shows the $\mathrm{C} / \mathrm{Co}$ values for ${ }^{137} \mathrm{Cs}$ elution during cycle \# 4 . The average bed volume from the start to the end of elution was $11.7 \mathrm{~mL}$. The flow rate, based on the elution volume, was $0.99 \mathrm{BV} / \mathrm{h}$. The $\mathrm{C} / \mathrm{Co}$ peak for ${ }^{137} \mathrm{Cs}$ was exhibited at $4 \mathrm{BV}$ and the value was 103 times its feed concentration. The $\mathrm{C} / \mathrm{Co}$ reached 0.01 at $11 \mathrm{BV}$, and then gradually increased to a final value of 0.1 . It is not clear why the $\mathrm{C} / \mathrm{Co}$ increased after $11 \mathrm{BV}$ and remained level at $15 \mathrm{BV}$. Also, the post-elution rinse and regeneration samples were not collected. 


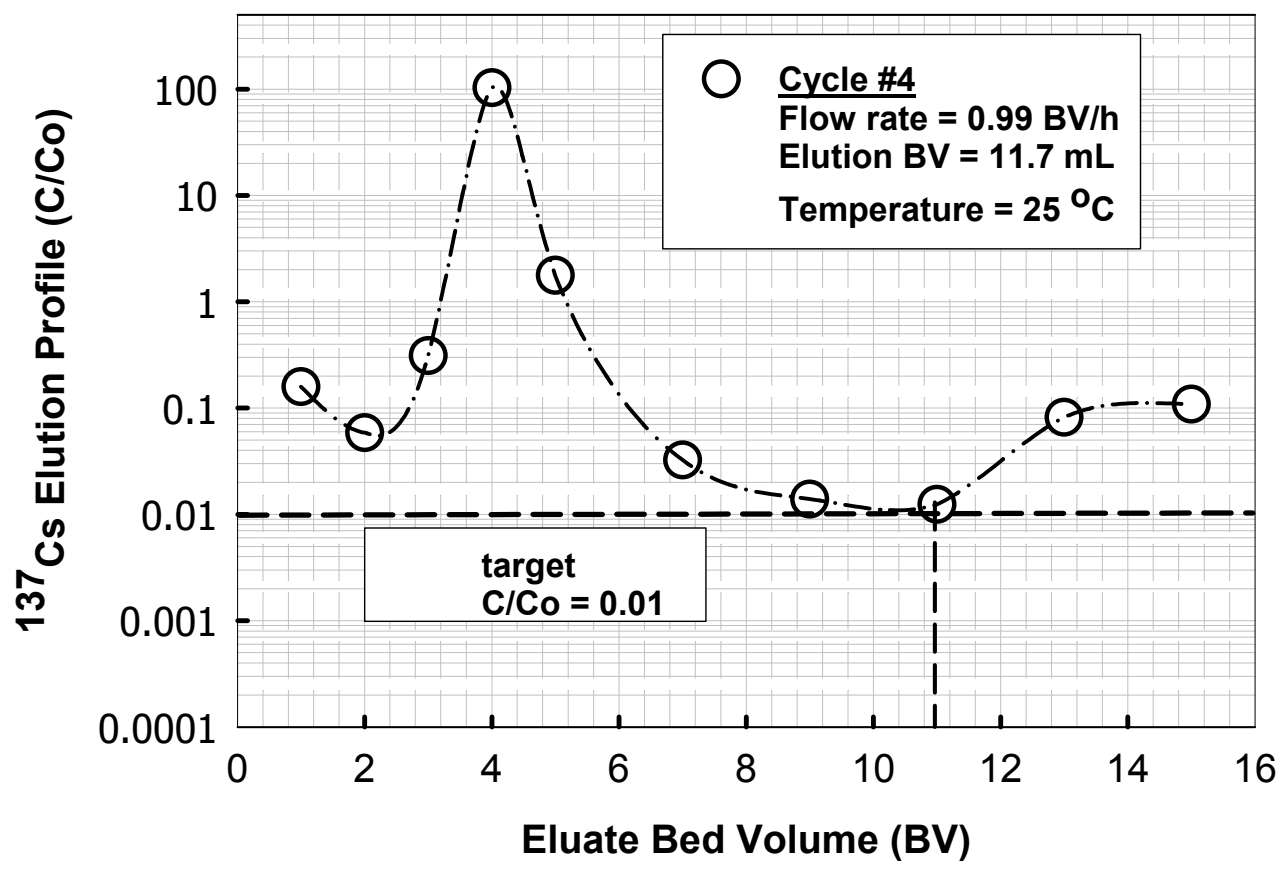

Figure 4-14. ${ }^{137}$ Cs Elution Curve - Cycle \#4

The ${ }^{137} \mathrm{Cs}$ elution for cycle $\# 5$ is shown in Figure 4-15. The elution flow rate was $0.95 \mathrm{BV} / \mathrm{h}$, based on average elution volume. The $\mathrm{C} / \mathrm{Co}$ peak was exhibited at about $4 \mathrm{BV}$ with a value of 100 . The $\mathrm{C} / \mathrm{Co}$ reached a value of 0.01 at $11 \mathrm{BV}$, then increased momentarily to 0.1 before dropping back to 0.002 at $15 \mathrm{BV}$. The ${ }^{137} \mathrm{Cs}$ concentration in the composite eluate solution was $1.59 \times 10^{3} \mu \mathrm{Ci} / \mathrm{mL}$. The volume of composite eluate collected during the elution was $211 \mathrm{~mL}$. The $\mathrm{C} / \mathrm{Co}$ for ${ }^{137} \mathrm{Cs}$ in the post-elution rinse increased after passing the first BV of DI water into the column, and then edged up again after $4 \mathrm{BV}$ of solution passed through the column. The $\mathrm{C} / \mathrm{Co}$ for ${ }^{137} \mathrm{Cs}$ in the regeneration solution $(0.25 \mathrm{M} \mathrm{NaOH})$ declined steadily during the first $5 \mathrm{BVs}$, and then slightly increased in the last $3 \mathrm{BV}$. The $\mathrm{C} / \mathrm{Co}$ rise and fall of the ${ }^{137} \mathrm{Cs}$ concentration in the post-elution rinse and regeneration solutions were observed in several elution cycles where the data were collected. 


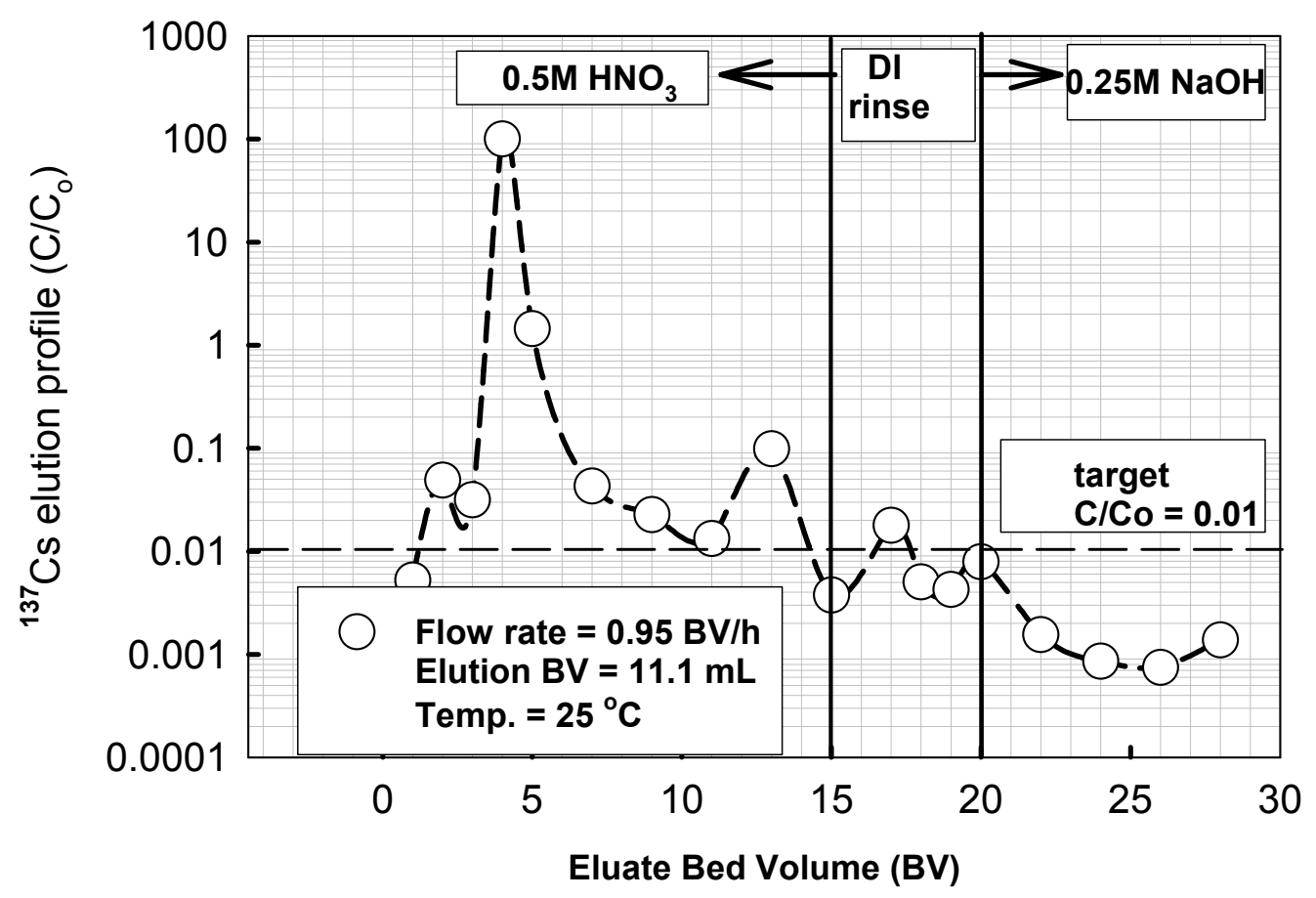

Figure 4-15. ${ }^{137}$ Cs Elution Curve - Cycle \#5

Figure 4-16 displays the $\mathrm{C} / \mathrm{Co}$ for ${ }^{137} \mathrm{Cs}$ elution in cycle \#6. The elution was extended to 28 $\mathrm{BV}$ to ensure all elutable $\mathrm{Cs}$ was removed from the resin. The $\mathrm{C} / \mathrm{Co}$ peak with a value of 126 was observed at $4 \mathrm{BV}$. The $\mathrm{C} / \mathrm{Co}$ reached a value of 0.02 at $10 \mathrm{BV}$, and then a long tail that lasted up to $24 \mathrm{BV}$ was exhibited. The $\mathrm{C} / \mathrm{Co}$ of 0.01 was reached after $24 \mathrm{BV}$ of eluent passed through the column. The ${ }^{137} \mathrm{Cs}$ concentration in the composite eluate solution was $8.9 \times 10^{2} \mu \mathrm{Ci} / \mathrm{mL}$, and the volume of the composite solution was $339 \mathrm{~mL}$. The seemingly low ${ }^{137} \mathrm{Cs}$ concentration in the composite eluate solution is due to large volume of acid dilution.

Figure 4-17 shows the $\mathrm{pH}$ and the concentration of $\mathrm{Na}^{+}$in eluate samples in cycle \# 6 . The $\mathrm{pH}$ of the eluate samples remained at $\sim 2.5$, except in the sample collected at $11 \mathrm{BV}$. The concentration of $\mathrm{Na}^{+}$decreased initially from $\sim 0.8 \underline{\mathrm{M}}$ at $1 \mathrm{BV}$ to $0.22 \mathrm{M}$ at $13 \mathrm{BV}$. The $\mathrm{Na}^{+}$ concentration $(1.2 \underline{\mathrm{M}})$ and the $\mathrm{pH}(7.3)$ observed at $11 \mathrm{BV}$ were not expected. The $\mathrm{C} / \mathrm{Co}$ of cesium in the post-elution DI rinse increased from less than 0.002 to value of 0.03 . The reason for the increase in the $\mathrm{C} / \mathrm{Co}$ of cesium in the post-elution DI water rinse is not known. 


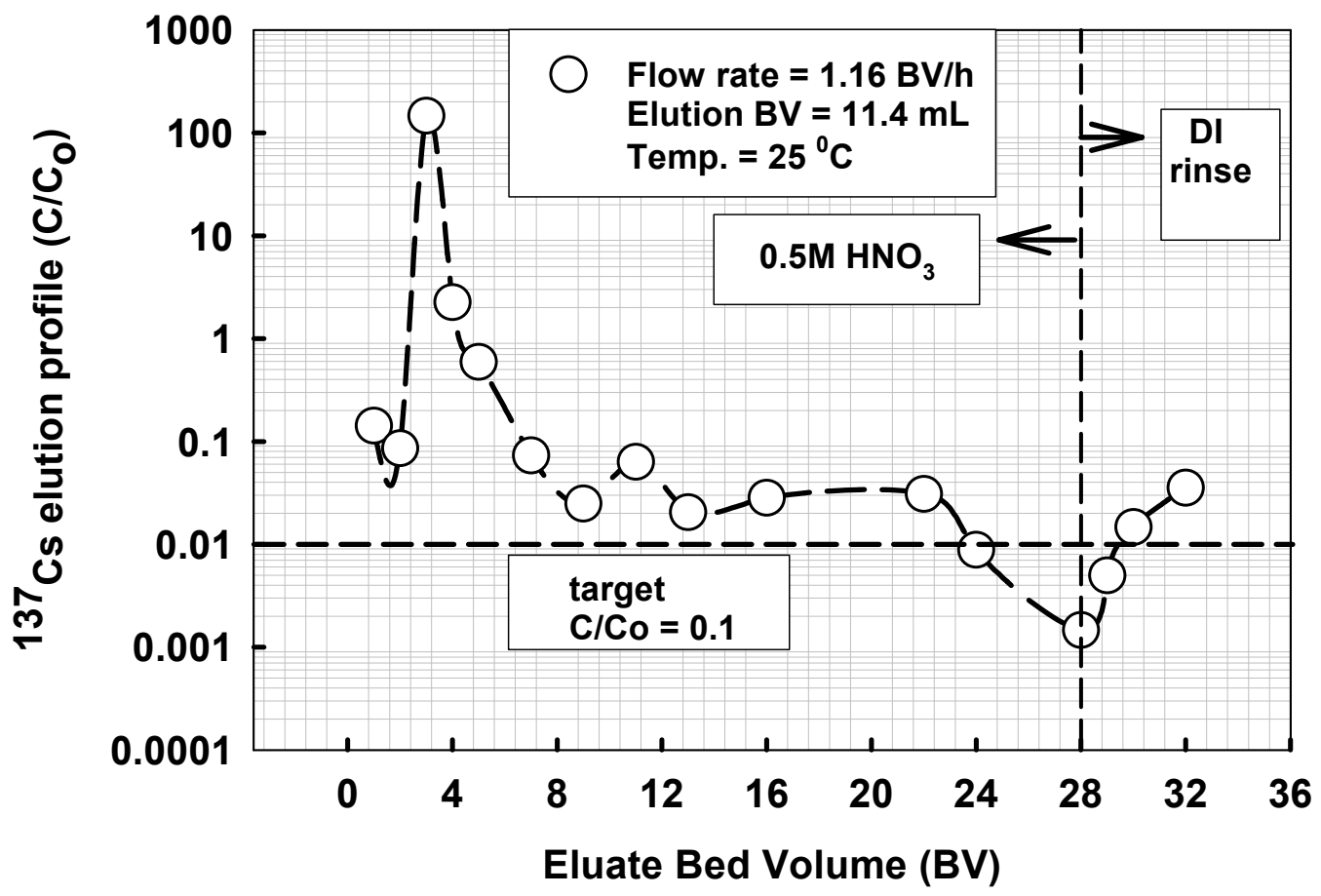

Figure 4-16. ${ }^{137}$ Cs Elution Curve - Cycle \#6

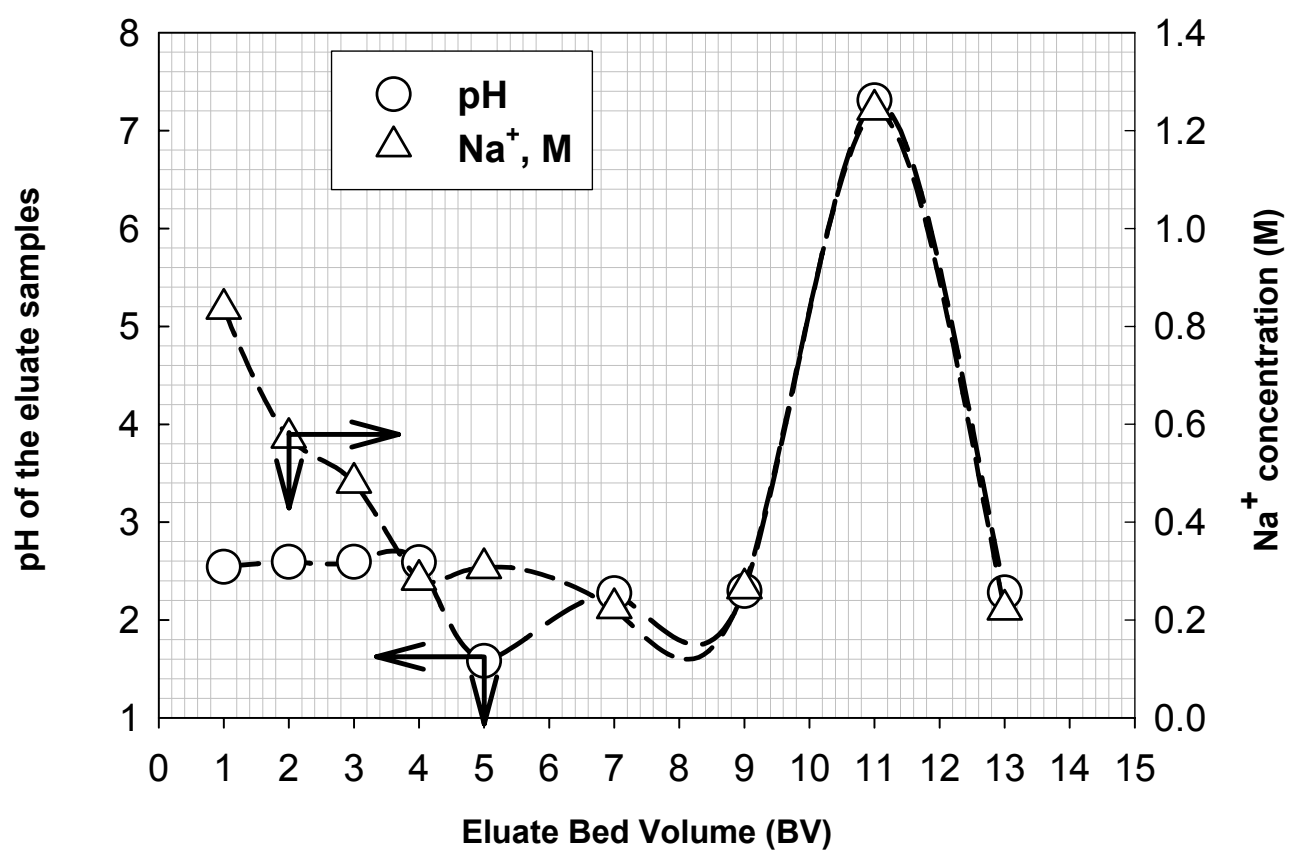

Figure 4-17. $\mathrm{pH}$ and $\mathrm{Na}^{+}$in Eluate Sample - Cycle \#6 


\subsection{TECHNETIUM LOADING CYCLES}

Five loading/elution/regeneration cycles were performed to remove ${ }^{99} \mathrm{Tc}$ from AW-101 waste sample. The effluent from cesium ion exchange column testing was used for the technetium ion exchange column testing. Two ion exchange columns (lead and lag) were previously loaded with rhenium from AW-101 simulant until $~ 10 \%$ breakthrough occurred, and then eluted with de-ionized water at $65{ }^{\circ} \mathrm{C}$. The columns were stored in DI water for several weeks prior to their transfer into radiochemical hood. After the equipment transfer, the columns were regenerated separately with $0.25 \mathrm{M} \mathrm{NaOH}$, and then connected in series for technetium loading. The columns were loaded in the downward direction at a rate of $3 \mathrm{BV} / \mathrm{h}$.

The ${ }^{99} \mathrm{Tc}$ breakthrough curves for the five lead column loading cycles are shown in Figure 4-18. The C/Co ${ }^{99} \mathrm{Tc}$ activity of effluent samples/activity of ${ }^{99} \mathrm{Tc}$ in feed) was plotted as a function of the number of BV. The concentration of ${ }^{99} \mathrm{Tc}$ in the feed (AW-101 waste sample) was $6.62 \times 10^{-2} \mu \mathrm{Ci} / \mathrm{mL}$. Since ${ }^{99} \mathrm{Tc}$ is not adsorbed on SuperLig ${ }^{\circledR} 644$ resin, the effluent from the cesium ion exchange columns was assumed to have the same concentration as the diluted AW-101 waste filtrate at $5 \underline{\mathrm{M} \mathrm{Na}}{ }^{+}$. Thus, no additional characterization was performed on the effluent composite solutions from cesium ion exchange columns.

Table 4-6 shows a summary of the ${ }^{99} \mathrm{Tc}$ loading performance for five cycles. The values presented in the table are $\mathrm{BV}$ processed during each loading cycle at $\mathrm{C} / \mathrm{Co}$ of 0.1 with $95 \%$ confidence interval. It should be noted that the average loading was better than $250 \mathrm{BV}$ at the $10 \%$ breakthrough. There is no significant difference in the loading performance of cycles \#1-5, even though cycle \# 1 appears to be slightly better than the other cycles. In other words, the performance of the resin did not deteriorate up to the fifth cycle. Based on these results, it can be inferred that this batch of SuperLig ${ }^{\circledR} 639$ resin (batch \# I-R2-03-27-0220-45) performed better than all previous batches

Table 4-6. Statistical Summary of ${ }^{99} \mathrm{Tc}$ Lead Column Performance at $\mathrm{C} / \mathrm{Co}=\mathbf{0 . 1}$

\begin{tabular}{|c|c|c|c|}
\hline Cycle \# & Mean value (BV) & Lower Limit (BV) & Upper Limit (BV) \\
\hline 1 & 262 & 251 & 282 \\
\hline 2 & 250 & 240 & 267 \\
\hline 3 & 258 & 252 & 265 \\
\hline 4 & 251 & 249 & 252 \\
\hline 5 & 251 & 248 & 253 \\
\hline
\end{tabular}




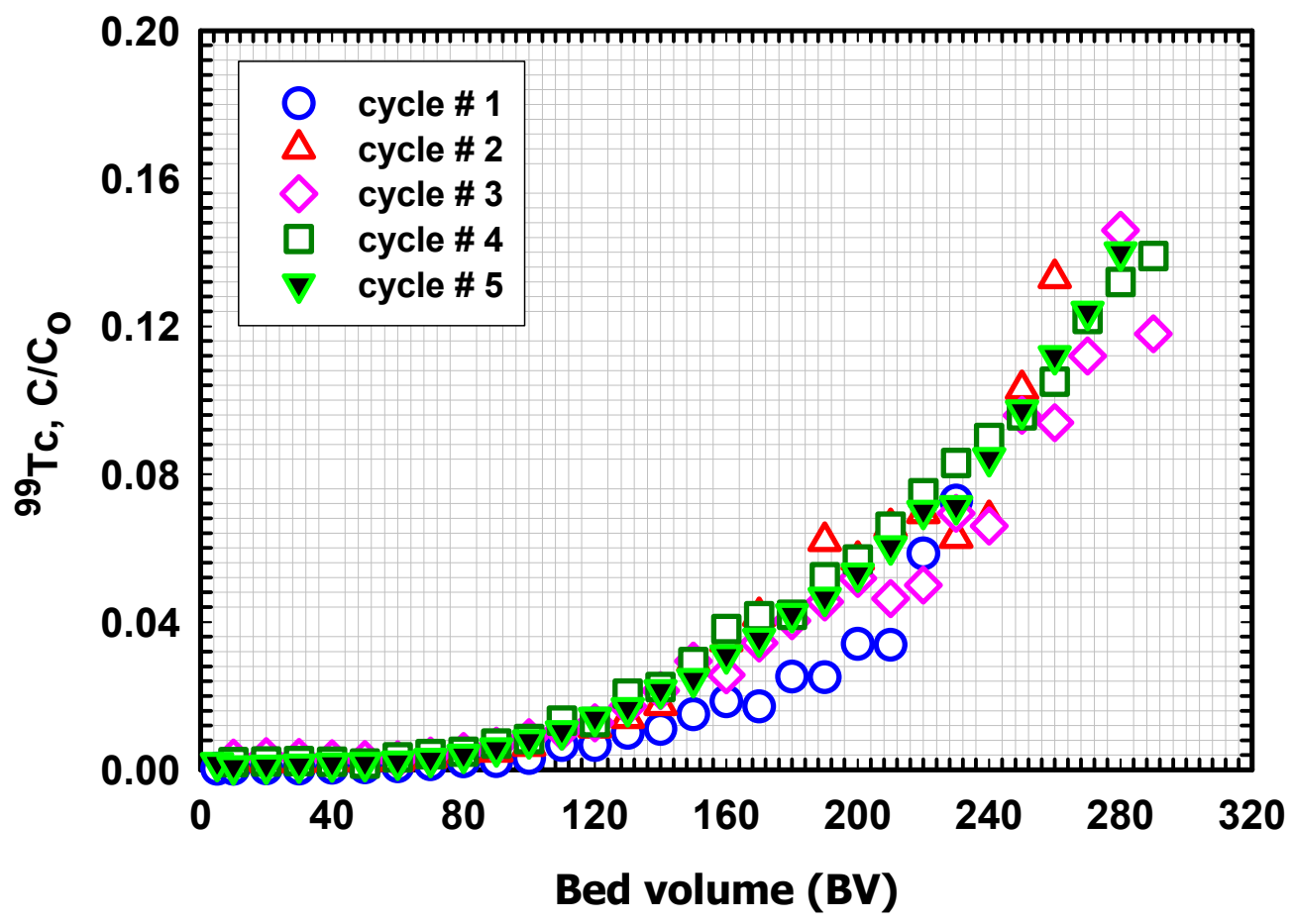

Figure 4-18. ${ }^{99}$ Te Breakthrough Curves - All Cycles

Figure 4-19 displays the ${ }^{99} \mathrm{Tc}$ loading data in cycle \#1. The ${ }^{99} \mathrm{Tc}$ concentration in curie per mole of $\mathrm{Na}^{+}$was plotted on a log scale as a function of the volume (BV) of waste sample processed. The concentration in the effluent samples from the lead column was nearly a straight line on the log scale, as expected. The performance of the dual ion exchange columns was excellent. The ${ }^{99} \mathrm{Tc}$ concentration was below the contract limit after processing $230 \mathrm{BVs}$. The lag column data show no immediate breakthrough after processing nearly $230 \mathrm{BV}$. The volume of effluent composite product collected from the lag column was $2964 \mathrm{~mL}$; the ${ }^{99} \mathrm{Tc}$ concentration in the product was $\sim 3.66 \times 10^{-5} \mu \mathrm{Ci} / \mathrm{mL}$. Based on initial ${ }^{99} \mathrm{Tc}$ concentration of $6.62 \times 10^{-2} \mu \mathrm{Ci} / \mathrm{mL}$, the DF achieved for cycle \# 1 was $\sim 1810$. The percent removal of ${ }^{99} \mathrm{Tc}$ from the AW-101 sample was $\sim 99.94 \%$.

Figure 4-20shows the loading data for ${ }^{99} \mathrm{Tc}$ in cycle $\# 2$. The loading performance of lead and lag columns was very good. The ${ }^{99} \mathrm{Tc}$ concentration in the effluent samples was below the contract limit of $5.83 \times 10^{-5} \mathrm{Ci} / \mathrm{mole} \mathrm{Na}^{+}$even after processing $280 \mathrm{BV}$ of sample. The lead and lag column effluent had Tc concentration below $1 \times 10^{-7} \mathrm{Ci} / \mathrm{mole}$ of $\mathrm{Na}^{+}$until $100 \mathrm{BV}$ of sample was processed. The concentration in lead column effluent was a straight-line on the $\log$ scale after $100 \mathrm{BV}$ of solution was processed. The Tc concentration in the lag effluent remained constant below $10^{-7}$ throughout the run. The volume of effluent composite product generated from cycle \#2 was $3570 \mathrm{~mL}$; the ${ }^{99} \mathrm{Tc}$ concentration in the product was $5.95 \mathrm{x}$ $10^{-5} \mu \mathrm{Ci} / \mathrm{mL}$. The percent removal of ${ }^{99} \mathrm{Tc}$ (pertechnetate) in cycle \#2 was $99.91 \%$; with a DF of 1100 . 


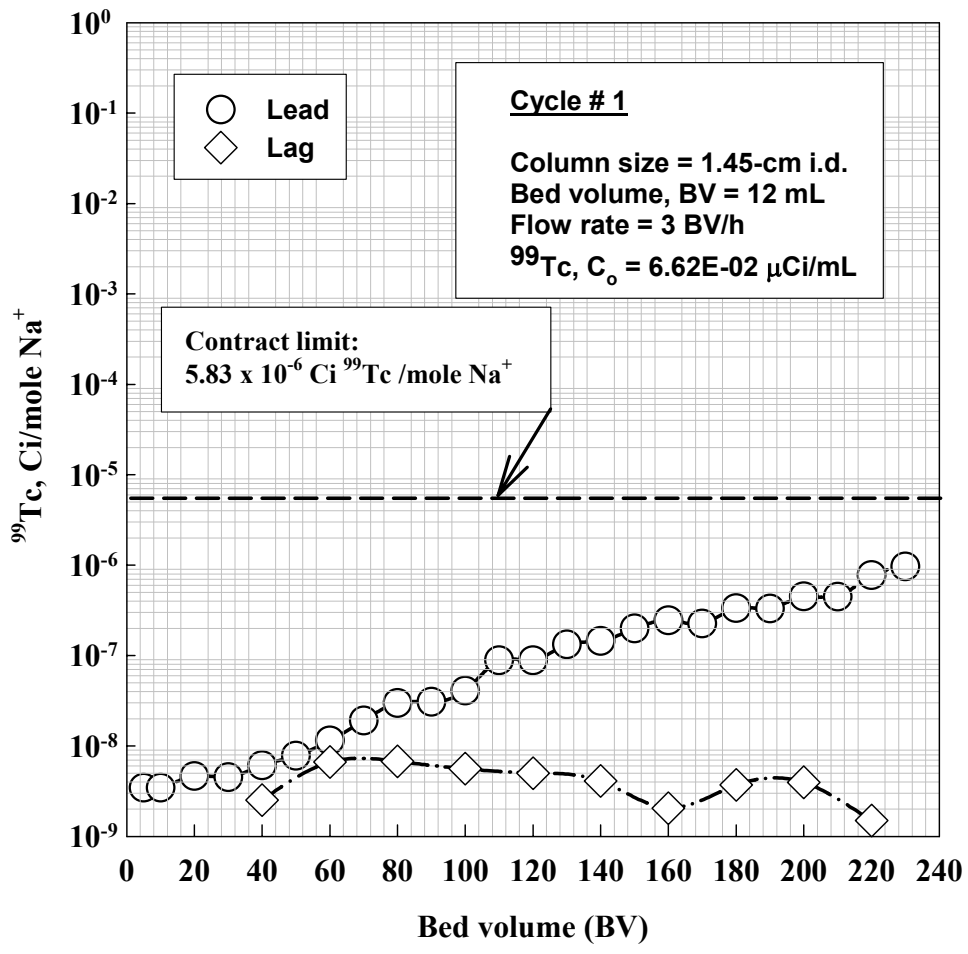

Figure 4-19. ${ }^{99}$ Te Breakthrough Curves - Cycle \#1

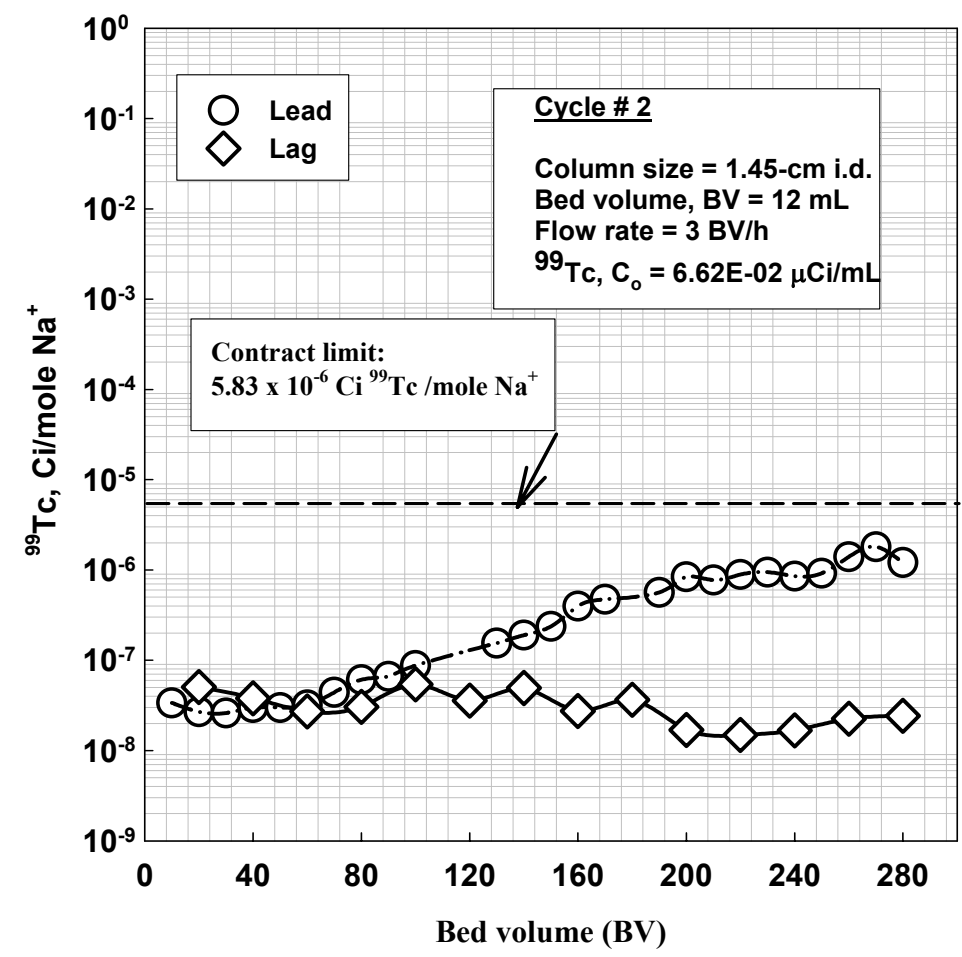

Figure 4-20. ${ }^{99}$ Tc Breakthrough Curves - Cycle \#2 
The loading data for ${ }^{99} \mathrm{Tc}$ in cycle \#3 are displayed in Figure 4-21. The performance of dual ion exchange columns was again very good in cycle \#3. The first sample from the lead column at $5 \mathrm{BV}$ exhibited unexpected spike in Tc concentration; the concentration then remained constant below $4 \times 10^{-7} \mathrm{Ci} /$ mole Na $^{+}$until $60 \mathrm{BV}$ of sample was processed. After $60 \mathrm{BV}$, the concentration was nearly a straight line on the log scale. The lag column performance was excellent, although some scatter of the data was observed. The Tc concentration in the lag effluent samples was constant at $\sim 1 \times 10^{-8} \mathrm{Ci} / \mathrm{mole}$ of $\mathrm{Na}^{+}$ throughout the run. The volume of effluent composite product generated in cycle \#3 was $3600 \mathrm{~mL}$; the ${ }^{99} \mathrm{Tc}$ concentration in the product was $4.2 \times 10^{-5} \mu \mathrm{Ci} / \mathrm{mL}$. The percent removal for the ${ }^{99} \mathrm{Tc}$ from the AW-101 was $>99.94 \%$ and the DF achieved was $\sim 1570$.

Figure 4-22 shows the loading data for ${ }^{99} \mathrm{Tc}$ in cycle \#4. The performance of the dual column system was similar to cycle \#3. The ${ }^{99} \mathrm{Tc}$ concentration for lead column was constant at $5 \times 10^{-8} \mathrm{Ci} / \mathrm{mole} \mathrm{Na}^{+}$until the initial $50 \mathrm{BV}$ of feed was processed. The concentration then exhibited a straight-line on $\log$ scale until $170 \mathrm{BV}$, where the slope shifted but the line remained straight. The concentration in the effluent from the lag column was at $1 \times 10-8$ $\mathrm{Ci} /$ mole $\mathrm{Na}^{+}$, which is significantly below contract limit $\left(5.83 \times 10^{-5} \mathrm{Ci} / \mathrm{mole} \mathrm{Na}^{+}\right)$. The amount of effluent composite product collected in cycle \#4 was $3650 \mathrm{~mL}$. The ${ }^{99} \mathrm{Tc}$ concentration in the product was $3.7 \times 10^{-5} \mu \mathrm{Ci} / \mathrm{mL}$; the corresponding DF was 1770 and the percent removal of ${ }^{99} \mathrm{Tc}$ (pertechnetate) was $99.94 \%$.

The loading data for ${ }^{99} \mathrm{Tc}$ in cycle \#5 is displayed in Figure 4-23. The ${ }^{99} \mathrm{Tc}$ concentration per mole of $\mathrm{Na}^{+}$was plotted in log curve as a function of $\mathrm{BV}$ processed. The horizontal dashed line shows the contract limit $\left(5.83 \times 10^{-5} \mathrm{Ci}^{99} \mathrm{Tc} / \mathrm{mole}\right.$ of $\left.\mathrm{Na}^{+}\right)$. The results show excellent performance for both lead and lag columns; the ${ }^{99} \mathrm{Tc}$ concentration of effluent samples from both lead and lag columns was below contract limit throughout the run. The concentration of the lead column was nearly straight-line on the log scale, as expected. After processing $160 \mathrm{BV}$, the slope of the straight-line shifted slightly to the right. The volume of composite product generated during cycle \#5 was $3630 \mathrm{~mL}$. The ${ }^{99} \mathrm{Tc}$ concentration in the product solution was $2.94 \times 10^{-5} \mu \mathrm{Ci} / \mathrm{mL}$; the corresponding $\mathrm{DF}$ and the percent ${ }^{99} \mathrm{Tc}$ removal were $\sim 2250$ and $99.9 \%$, respectively. 


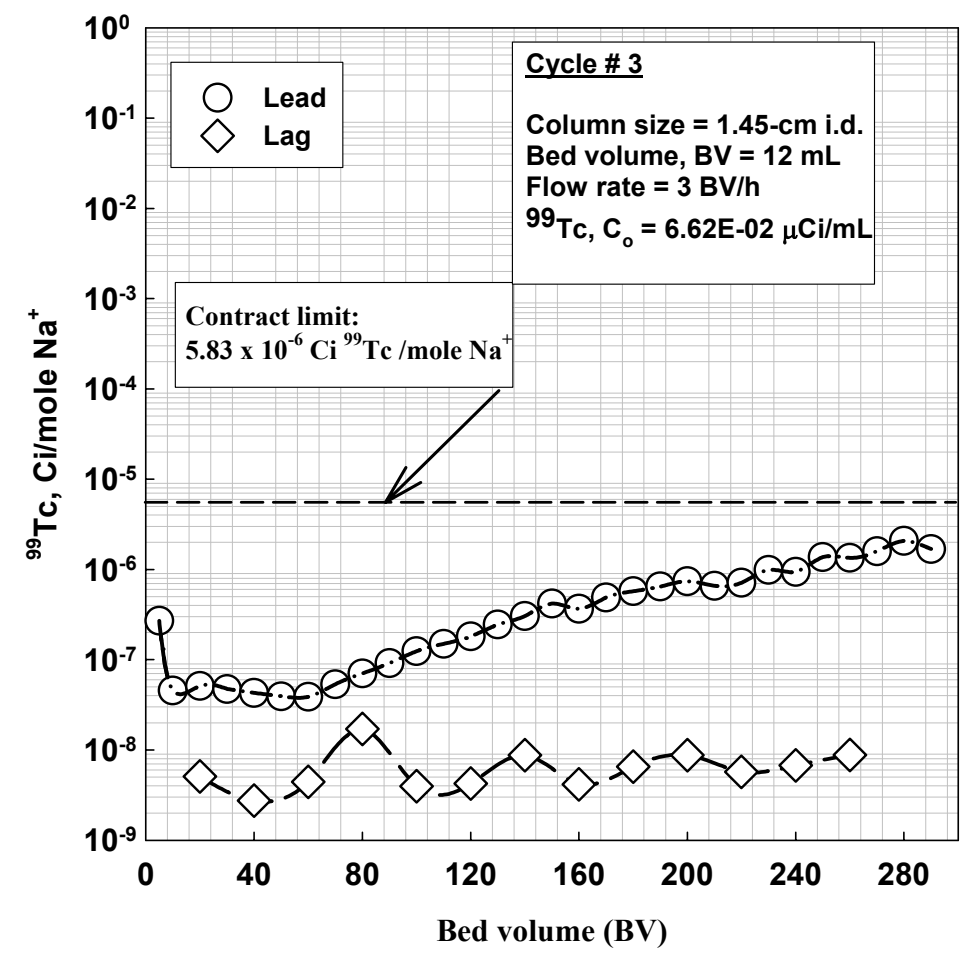

Figure 4-21. ${ }^{99}$ Tc Breakthrough Curves - Cycle \#3

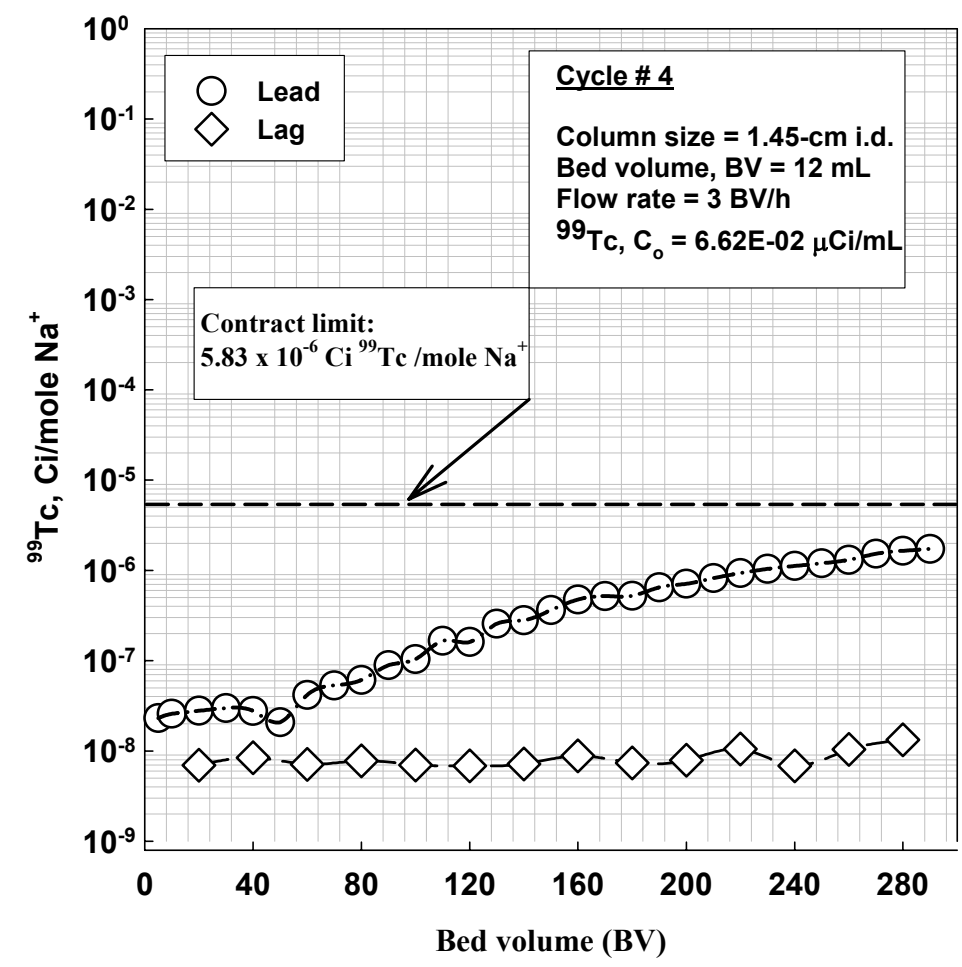

Figure 4-22. ${ }^{99}$ Tc Breakthrough Curves - Cycle \#4 


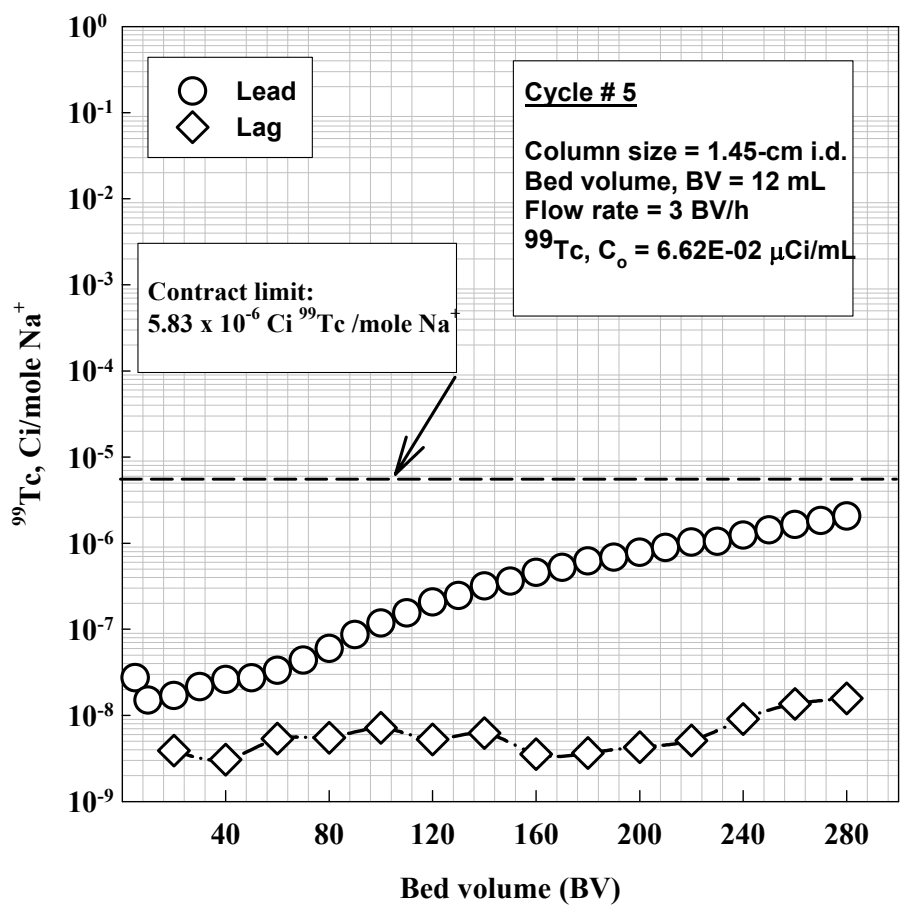

Figure 4-23. ${ }^{99}$ Te Breakthrough Curves - Cycle \#5

\subsection{TECHNETIUM DISPLACEMENT AND ELUTION}

After the completion of each loading cycle the lead and lag columns were disconnected, and then eluted separately with de-ionized water at a flow rate of $1 \mathrm{BV} / \mathrm{h}$ and at $65^{\circ} \mathrm{C}$. Prior to elution, feed displacement was performed with $4 \mathrm{BV}$ of $0.1 \underline{\mathrm{M} \mathrm{NaOH}}$ at a flow rate of $3 \mathrm{BV} / \mathrm{h}$. Feed displacement and eluate samples were collected only from the lead column in $0.5 \mathrm{BV}$ increments for the first $4 \mathrm{BV}$. After $4 \mathrm{BV}$, eluate samples were collected in $2 \mathrm{BV}$ increments. The concentrations of ${ }^{99} \mathrm{Tc}, \mathrm{K}^{+}$, and $\mathrm{Na}^{+}$in the feed displacement and eluate samples were determined by ICP-AES. The concentration of ${ }^{99} \mathrm{Tc}$ in selected samples was also determined by chemical separation, followed by beta counting. The $\mathrm{NO}_{3}{ }^{-}$concentration in selected samples was determined by ion chromatography (IC).

Figure 4-24 shows the lead column elution data for ${ }^{99} \mathrm{Tc}$ in cycle \# 1 . The $\mathrm{C} / \mathrm{Co}$ was plotted on $\log$ scale as a function of eluate BV. The open circle and triangle symbols show the pertechnetate species and total ${ }^{99} \mathrm{Tc}$, respectively. The total ${ }^{99} \mathrm{Tc}$ was measured by inductively coupled plasma - atomic emission spectroscopy (ICP-AES) and the pertechnetate fraction was determined by chemical separation, followed by beta counting. The ICP-AES and beta scintillation counting methods provided near identical results, thus suggesting that the ${ }^{99}$ Tc eluted was pertechnetate. 
It should be noted that after approximately $10 \mathrm{BV}$, the ICP-AES measurement reached its detection limit. Elution of ${ }^{99} \mathrm{Tc}$ from the lead column at $65^{\circ} \mathrm{C}$ was fast. The $\mathrm{C} / \mathrm{Co}$ peak was observed at $2.5 \mathrm{BV}$ with a value of 94 . The target $\mathrm{C} / \mathrm{Co}$ of 0.01 was reached after only 12 $\mathrm{BV}$ of eluent passed through the column. The target $(\mathrm{C} / \mathrm{Co}=0.01)$ was arbitrarily chosen by WTP to suggest an end of elution for the tests. The lag column was eluted at $65^{\circ} \mathrm{C}$, but no data were collected.

The concentrations of ${ }^{99} \mathrm{Tc}, \mathrm{K}^{+}, \mathrm{Na}^{+}$, and $\mathrm{NO}_{3}{ }^{-}$in the feed displacement and eluate samples for the lead column are shown in Figure 4-25. The $\mathrm{K}^{+}$and $\mathrm{Na}^{+}$concentration decreased sharply from at the beginning of the feed displacement step. The $\mathrm{K}^{+}$curve exhibited a broad peak between 3 and $4 \mathrm{BV}$, and then the $\mathrm{K}^{+}$concentration continued to decline. At $10 \mathrm{BV}$, the ICP-AES instrument detection limit was approached, where the measured values would not meet their required MRQ. The $\mathrm{Na}^{+}$concentration exhibited no distinct peak, but the concentration sharply decreased during feed displacement and at the beginning of elution.

The elution data for ${ }^{99} \mathrm{Tc}$ in cycle \#2 are shown in Figure 4-26. The elution curve was nearly identical to cycles \#1. The plot of $\mathrm{C} / \mathrm{Co}$ on $\log$ scale vs. eluate $\mathrm{BV}$ shows similar characteristics as cycle \# 1 . The $\mathrm{C} / \mathrm{Co}$ peak was observed at $2.5 \mathrm{BV}$ with a value of 92 . The $\mathrm{C} / \mathrm{Co}$ target of 0.01 (dashed line) was reached after passing $16 \mathrm{BV}$ of eluent through the column. The ICP-AES and chemical separation/beta counting methods provided near identical results until the volume of eluate processed was $12 \mathrm{BV}$. The ICP-AES measurements after $12 \mathrm{BV}$ were close to detection limit and therefore, the results were not as reliable.

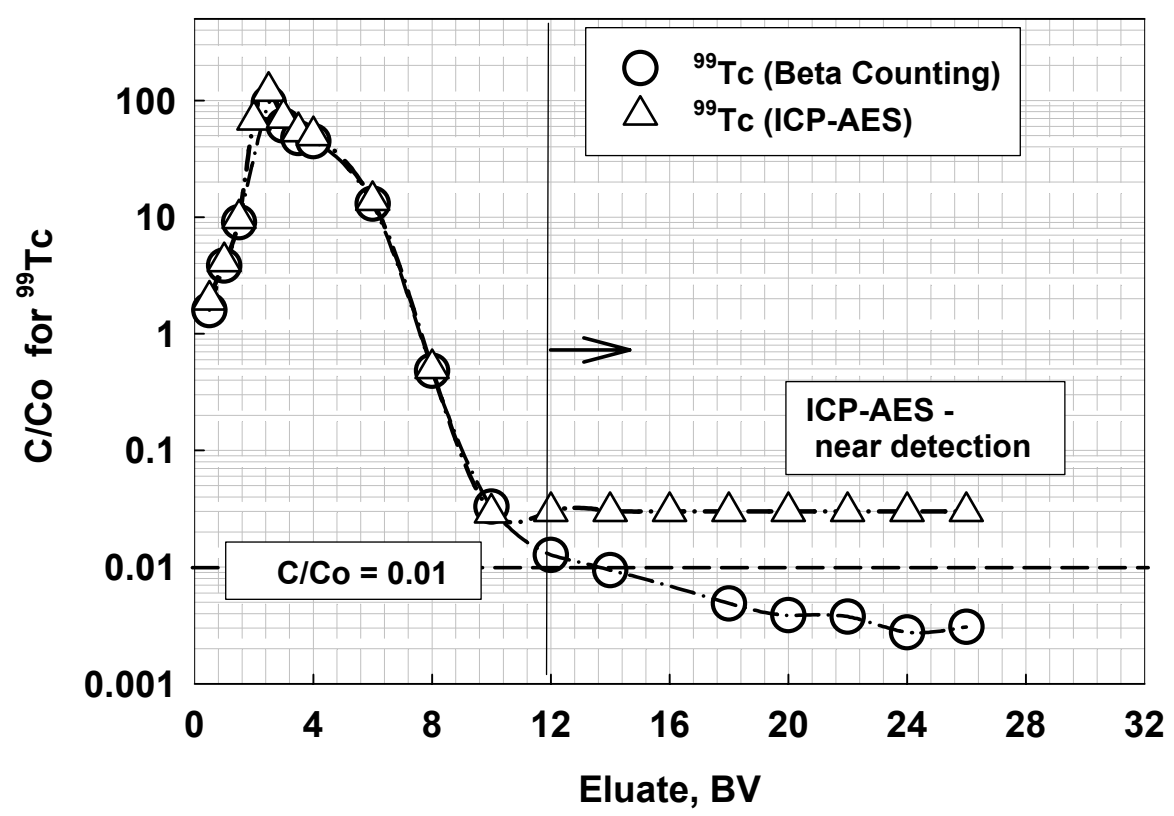

Figure 4-24. ${ }^{99}$ Tc Elution Curves - Cycle \#1 




Figure 4-25. Feed Displacement and Elution - Cycle \#1

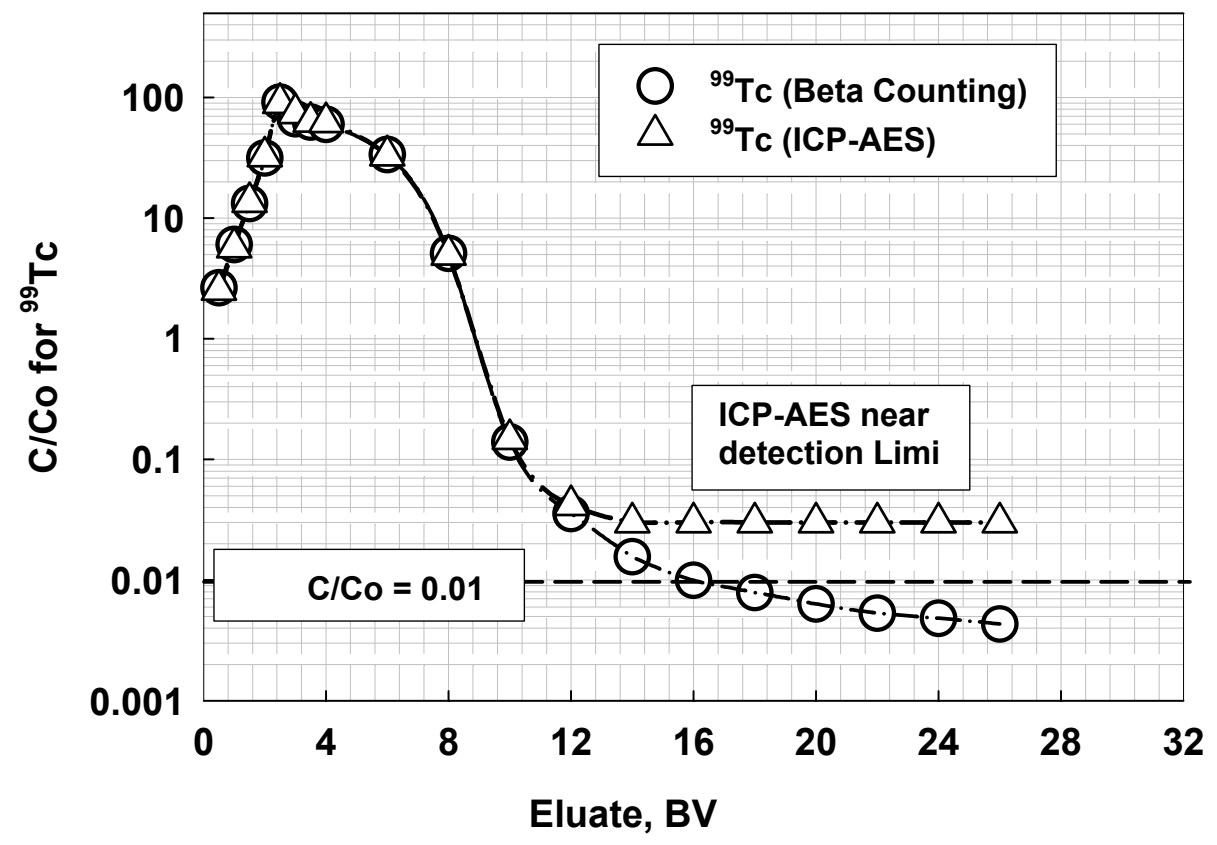

Figure 4-26. ${ }^{99}$ Tc Elution Curve - Cycle \# 2 
Concentrations of $\mathrm{K}^{+}$, and $\mathrm{Na}^{+}$and $\mathrm{NO}_{3}{ }^{-}$in the feed displacement and eluate samples are shown in Figure 4-27. The $\mathrm{K}^{+}$and $\mathrm{Na}^{+}$concentrations both decreased sharply after 2 to $3 \mathrm{BV}$ of the eluent passed through the column. A broad elution peak was exhibited for $\mathrm{K}^{+}$at $4 \mathrm{BV}$ and a small hump was observed for $\mathrm{Na}^{+}$at $8 \mathrm{BV}$. It is not clear $\mathrm{f}$ the $\mathrm{Na}^{+}$hump was an experimental artifact or a real elution peak.

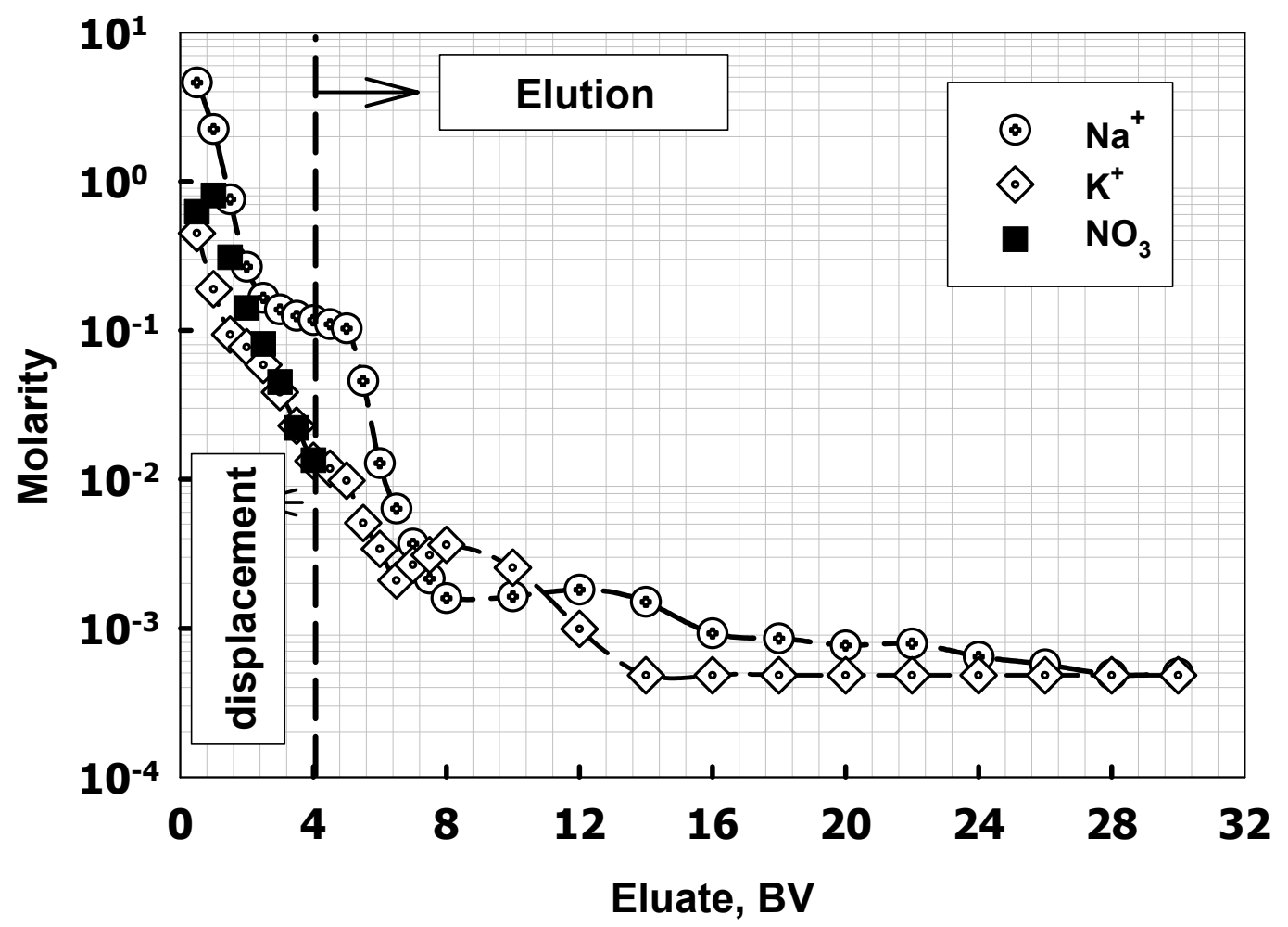

Figure 4-27. Feed Displacement and Elution - Cycle \# 2

The data for ${ }^{99} \mathrm{Tc}$ elution in cycle \#3 are presented in Figure 4-28. The elution performance was again comparable to the preceding cycles $\# 1$ and $\# 2$. The $\mathrm{C} / \mathrm{Co}$ peak was exhibited at 3.5 - $4 \mathrm{BV}$ with a value of 91 . The $\mathrm{C} / \mathrm{Co}$ of 0.01 was observed at $16 \mathrm{BV}$. The ICP-AES and beta counting methods provided comparable results, although after $6 \mathrm{BV}$ the measured values by the beta counting method were slightly higher than the ICP-AES results. It should be mentioned that the ICP-AES method measures total ${ }^{99} \mathrm{Tc}$ while the beta scintillation and counting method provides ${ }^{99} \mathrm{Tc}$ pertechnetate fraction. Since the SuperLig ${ }^{\circledR} 639$ adsorbs only pertechnetate fraction, the results by the two methods should be nearly the same. 


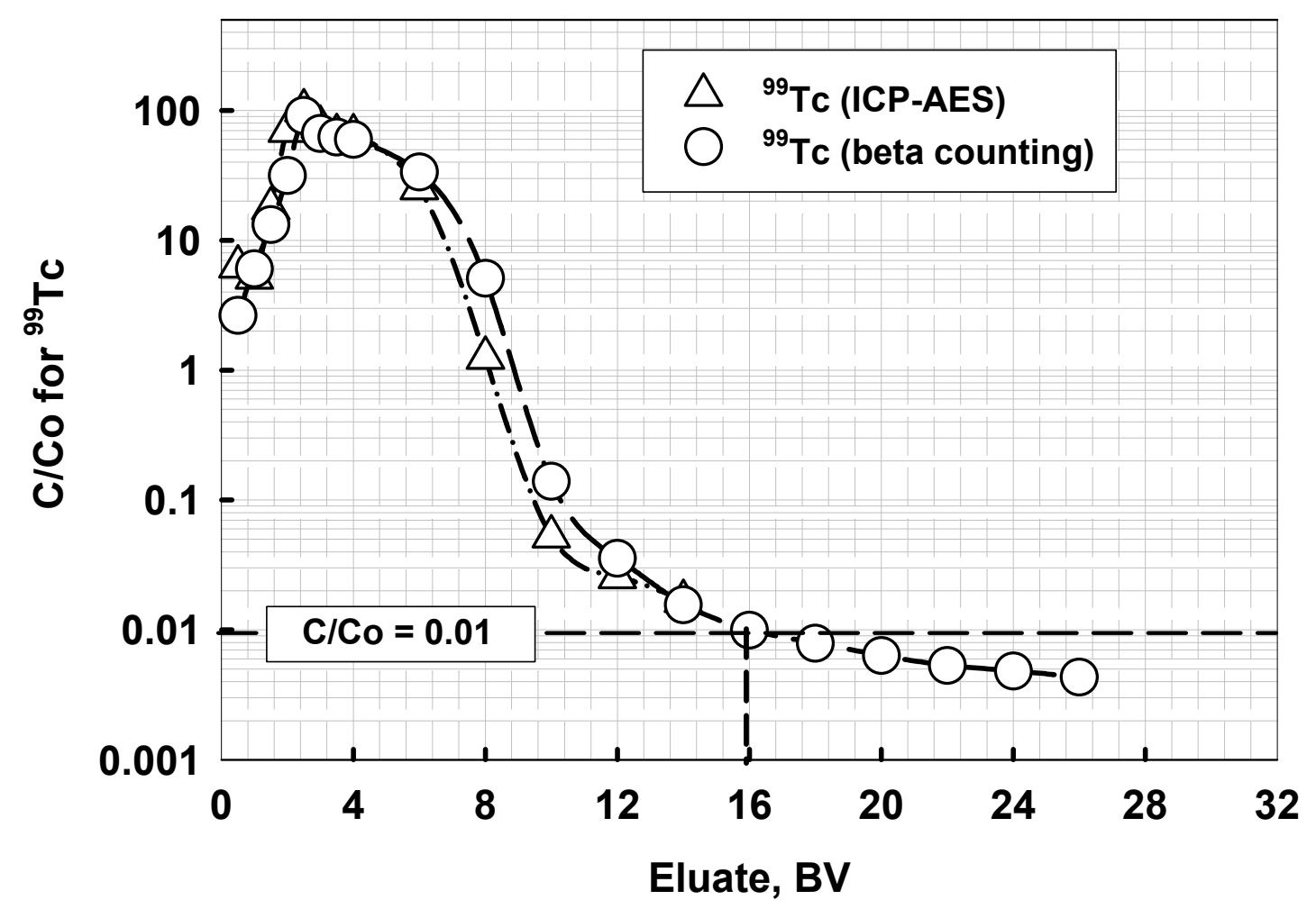

Figure 4-28. ${ }^{99}$ Tc Elution Curve - Cycle \# 3

Figure 4-29 shows the ${ }^{99} \mathrm{Tc}, \mathrm{K}^{+}, \mathrm{Na}^{+}$, and $\mathrm{NO}_{3}{ }^{-}$concentrations in the feed displacement and eluate samples in cycle \#3. The data show a sharp decrease of $\mathrm{K}^{+}, \mathrm{Na}^{+}$, and $\mathrm{NO}_{3}{ }^{-}$ concentrations at $2 \mathrm{BV}$ of feed displacement. The $\mathrm{Na}^{+}$concentration reached $0.1 \mathrm{M}$ at $2 \mathrm{BV}$ and then remained constant for the next $2 \mathrm{BV}$ of displacement. As the elution started, the $\mathrm{Na}^{+}$concentration decreased sharply again and the $\mathrm{K}^{+}$and $\mathrm{NO}_{3}{ }^{-}$concentrations continued their downward trend. The $\mathrm{K}^{+}, \mathrm{Na}^{+}$, and $\mathrm{NO}_{3}{ }^{-}$leveled off after $4 \mathrm{BV}$ of eluent passed through the column. At this point, the $\mathrm{K}^{+}$exhibited a broad hump next to the ${ }^{99} \mathrm{Tc}$ peaks at about $6 \mathrm{BV}$. Also, a broad $\mathrm{Na}^{+}$peak appeared at $8 \mathrm{BV}$. While the $\mathrm{K}^{+}$and $\mathrm{Na}^{+}$are not sufficiently resolved, their presence suggests that ${ }^{99} \mathrm{Tc}$ was present on the resin as potassium pertechnetate and sodium pertechnetate. 


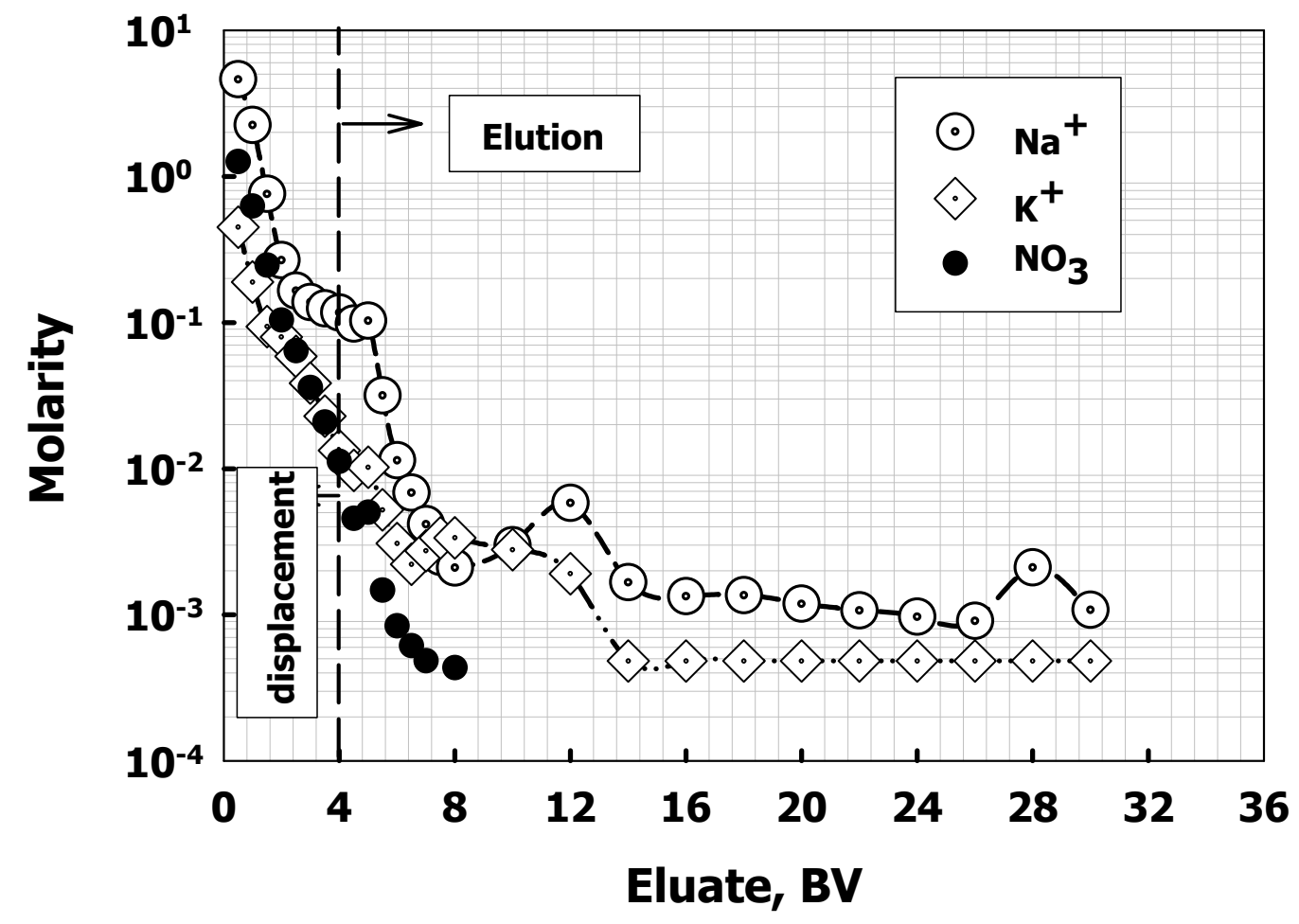

Figure 4-29. Feed Displacement and Elution - Cycle \# 3

Figure 4-30 shows the ${ }^{99} \mathrm{Tc}$ elution data in cycle \#4. Elution was performed on the lead and lag columns using de-ionized water at a flow rate of $1 \mathrm{BV} / \mathrm{h}$ and at $65^{\circ} \mathrm{C}$. However, data were collected on the lead column only. Since ICP-AES and chemical separation/beta counting methods provided identical results in cycle \#1 and cycle \#2, we used ICP-AES to measure ${ }^{99} \mathrm{Tc}$ in the first $12 \mathrm{BV}$ of eluate samples; beta counting was used to measure the ${ }^{99} \mathrm{Tc}$ concentration in the remaining samples. The ${ }^{99} \mathrm{Tc}$ elution was fast at $65^{\circ} \mathrm{C}$. The $\mathrm{C} / \mathrm{Co}$ peak was exhibited at $\sim 2.5 \mathrm{BV}$ with a peak value of 128 . The peak $\mathrm{C} / \mathrm{Co}$ value was $\sim 37 \%$ higher than the corresponding peak $\mathrm{C} / \mathrm{Co}$ values of cycles \#1, \# 2, and \# 3 . The $\mathrm{C} / \mathrm{Co}$ of 0.01 (target) was observed after $14 \mathrm{BV}$; the $\mathrm{C} / \mathrm{Co}$ gradually declined thereafter until the elution was terminated at $26 \mathrm{BV}$.

Figure 4-31 displays the concentration of ${ }^{99} \mathrm{Tc}, \mathrm{K}^{+}, \mathrm{Na}^{+}$, and $\mathrm{NO}_{3}{ }^{-}$in the feed displacement and eluate samples in cycle \#4. The general trend of $\mathrm{K}^{+}, \mathrm{Na}^{+}$, and $\mathrm{NO}_{3}{ }^{-}$concentrations in the displacement and elution steps was similar to that observed in cycle \#3. The $\mathrm{Na}^{+}$ concentration decreased sharply after $2 \mathrm{BV}$ of feed displacement and leveled off at $0.1 \underline{\mathrm{M}}$. The $\mathrm{K}^{+}$and $\mathrm{NO}_{3}$ concentrations continued to decline throughout the feed displacement. The concentrations of $\mathrm{K}^{+}, \mathrm{Na}^{+}$, and $\mathrm{NO}_{3}{ }^{-}$dropped by about $98 \%$ of their feed concentration after $4 \mathrm{BV}$ of feed displacement. During the elution, the $\mathrm{Na}^{+}$concentration resumed its sharp decline and it leveled off at about the same time the ${ }^{99} \mathrm{Tc}$ peak was observed. The broad hump for $\mathrm{K}^{+}$was observed next to the ${ }^{99} \mathrm{Tc}$ peak, although it was less pronounced this time. 


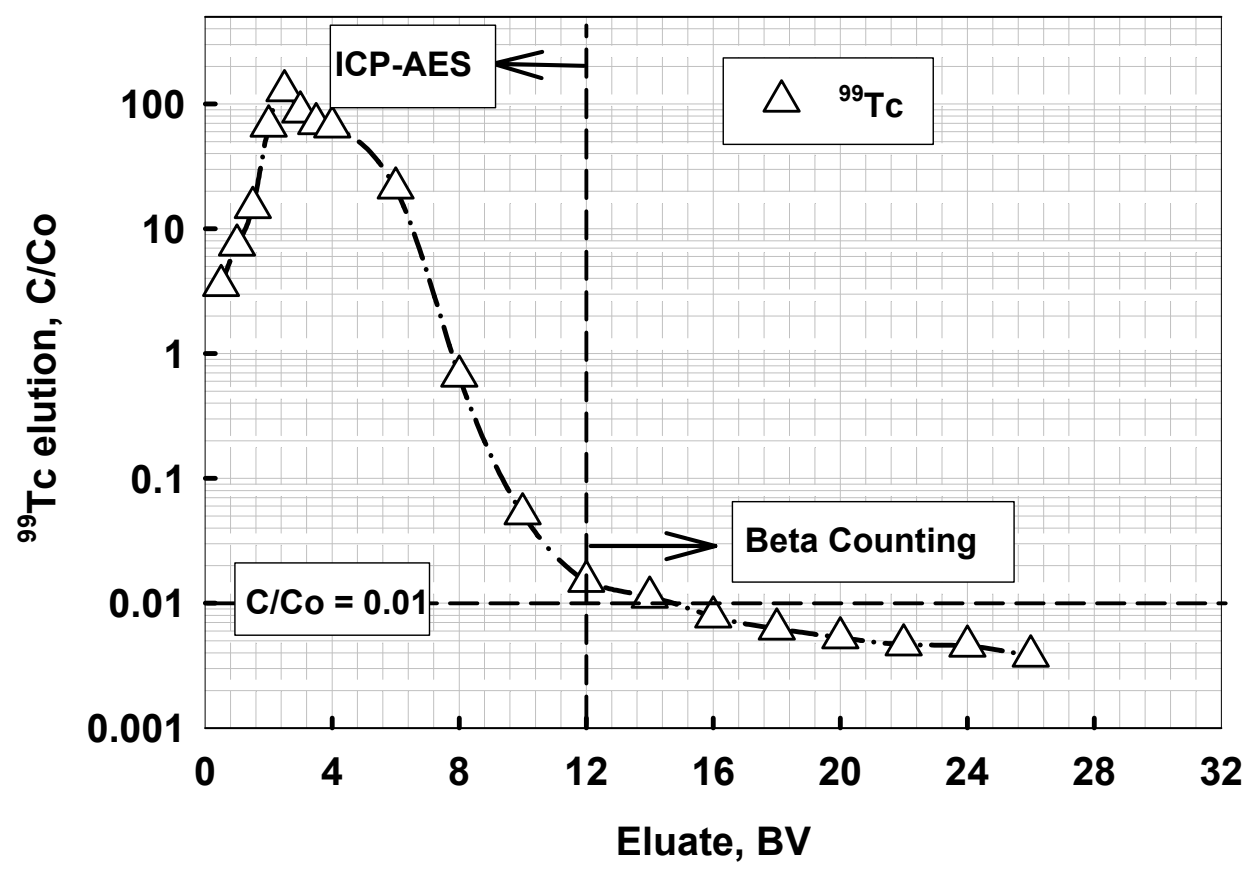

Figure 4-30. ${ }^{99}$ Te Elution Curve - Cycle \# 4

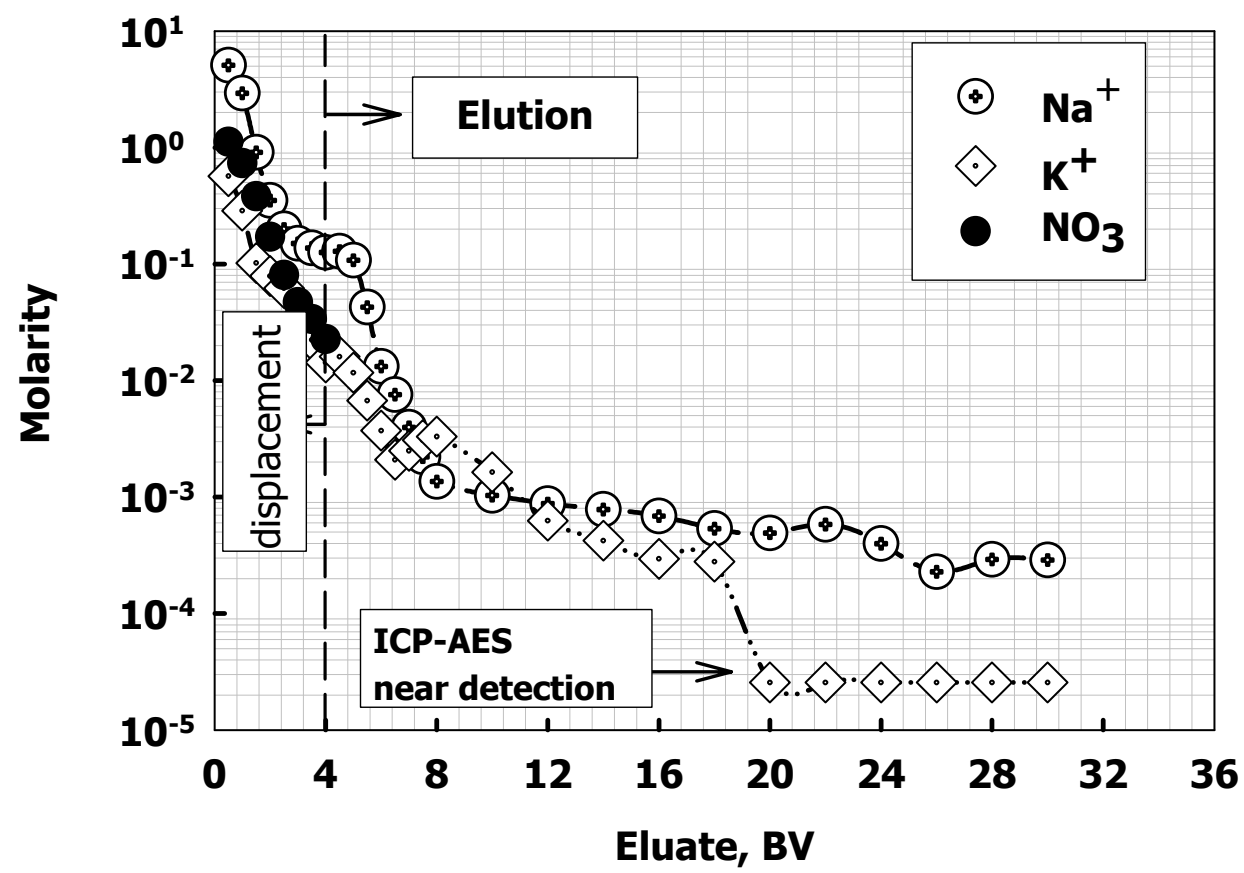

Figure 4-31. Feed Displacement and Elution - Cycle \# 4 


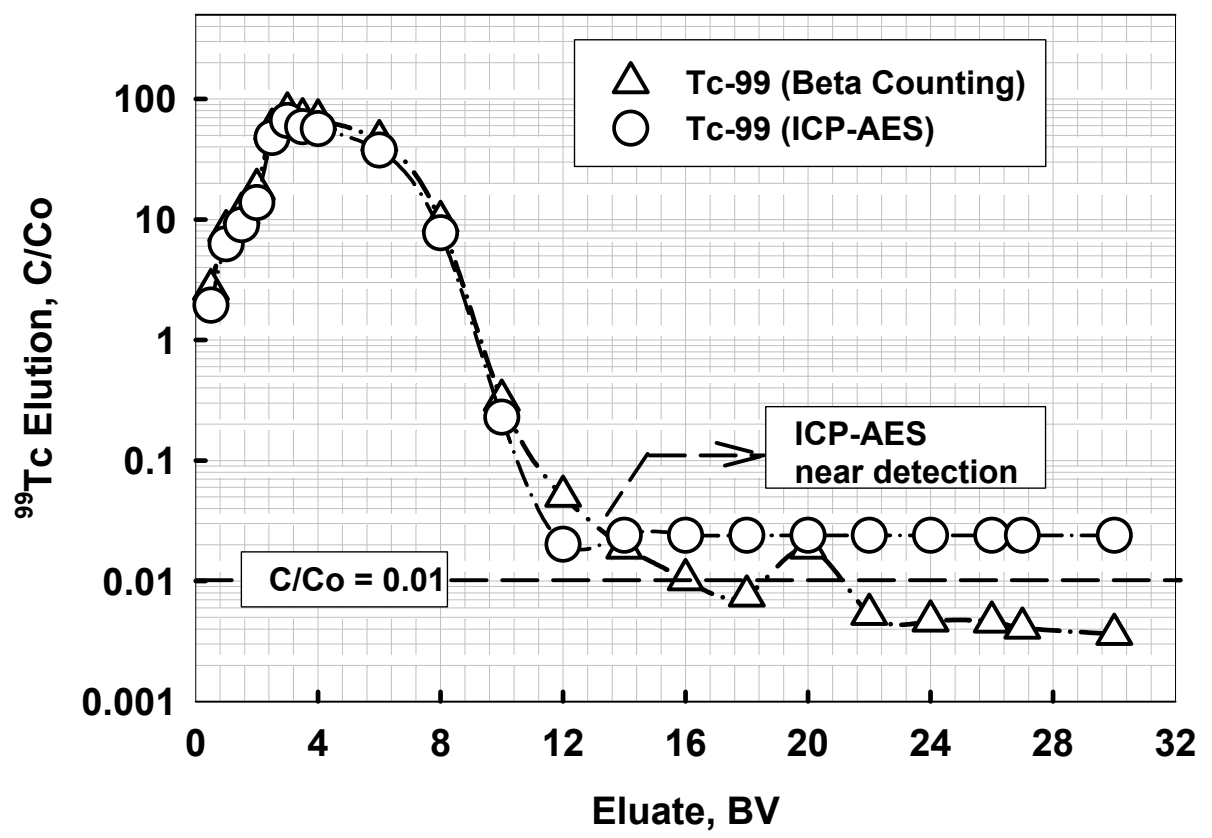

Figure 4-32. ${ }^{99}$ Tc Elution Curves - Cycle \# 5

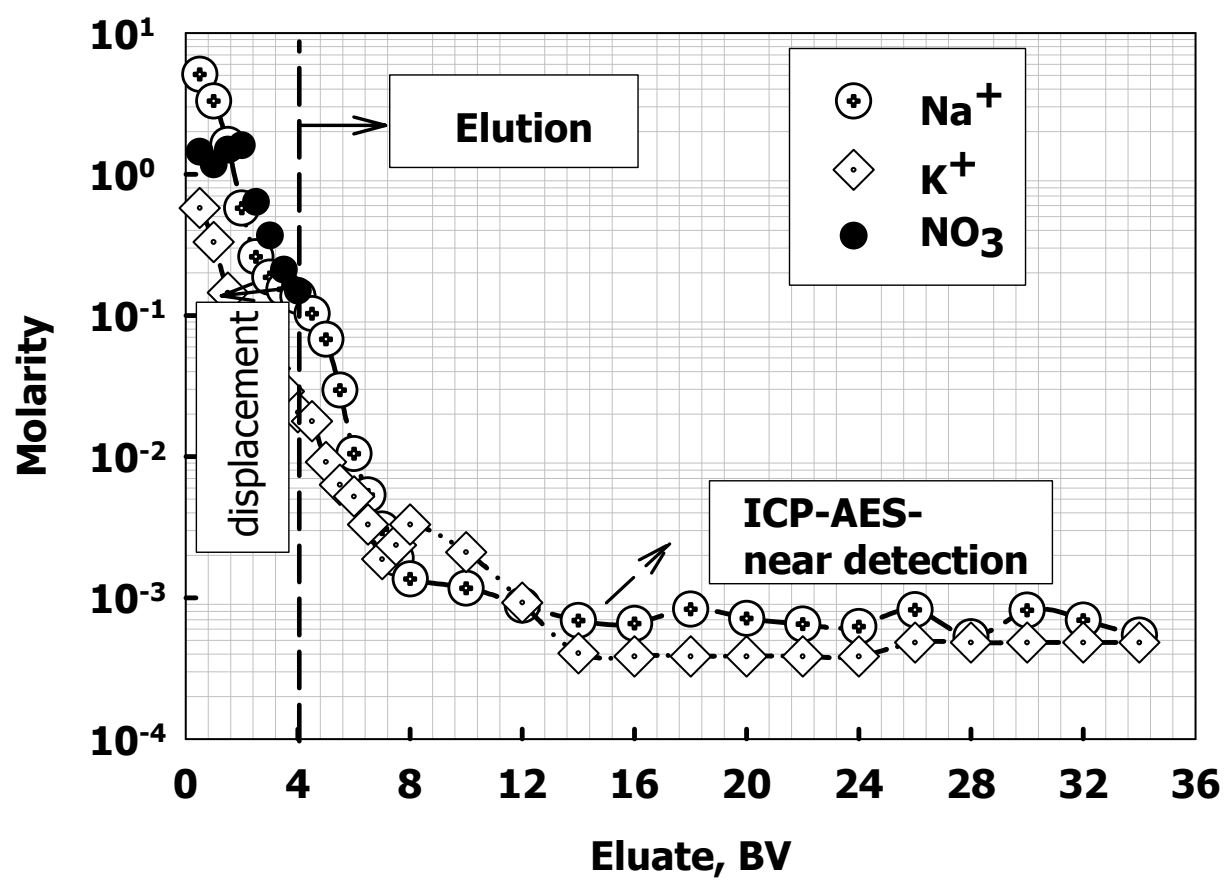

Figure 4-33. Feed Displacement and Elution - Cycle \# 5 


\section{WSRC-TR-2003-00098, REVISION 0 SRT-RPP-2003-00026, REVISION 0}

\subsection{EFFLUENT COMPOSITE PRODUCTS}

The effluent composite fractions from each technetium loading cycle were combined and thoroughly mixed in a 4-L carboy and then designated as "effluent composite product." Homogeneous sub-samples from each product were analyzed in duplicate to determine the concentration of radionuclide, metals and anions. The results are shown in Table 4-7. The average concentrations of ${ }^{137} \mathrm{Cs}$ and ${ }^{99} \mathrm{Tc}$ in all five composite products were less than WTP required cesium limit of $8.7 \times 10^{-2}$ and $2.9 \times 10^{-2} \mu \mathrm{Ci} / \mathrm{mL}$ for AW-101 waste sample, respectively. Thus, the performance of the cesium and technetium ion exchange dual systems has met the LAW vitrification criteria under the current experimental conditions. The percent removal of ${ }^{137} \mathrm{Cs}$ from the AW-101 waste sample for the six cycles was better than $99.99 \%$. The percent removal was calculated from the average concentrations of ${ }^{137} \mathrm{Cs}$ in feed (Appendix A-1) and in the effluent composite products (Table 4-7). The percent removal of ${ }^{99} \mathrm{Tc}$ (pertechnetate) from the AW-101 waste sample was better than $99.94 \%$. The contract requirement for overall Tc removal from envelopes $\mathrm{A}, \mathrm{B}$, and $\mathrm{C}$ was $80 \%{ }^{23}$ Thus, a minimum $95 \%$ removal of ${ }^{99} \mathrm{Tc}$ was required of envelopes A and B waste and only $30 \%$ removal was needed in envelope $\mathrm{C}$.

The overall DFs for ${ }^{137} \mathrm{Cs}$ and ${ }^{99} \mathrm{Tc}$ dual ion exchange columns are shown in Table 4.8. The DFs were calculated from the concentrations of ${ }^{137} \mathrm{Cs}$ and ${ }^{99} \mathrm{Tc}$ in effluent composite products (Table 4-7) and in the feed (Appendix A-1). The best DF for ${ }^{137} \mathrm{Cs}\left(5.0 \times 10^{5}\right)$ was achieved in cycle $\# 1$, as expected. The average DF from other five cycles was $\sim 4.8 \times 10^{4}$. The average DF obtained for ${ }^{99} \mathrm{Tc}$ cycles was $1.7 \times 10^{3}$, which significantly exceeded required DF $(\sim 30)$ for AW-101 waste sample. The good performance exhibited by SuperLig ${ }^{\circledR} 639$ columns could be due to improved resin manufacturing process.

The DF for major constituents of interest in the feed is shown in Table 4-8. The DF obtained for $\mathrm{Al}^{+}, \mathrm{Na}^{+}$, and $\mathrm{K}^{+}$was about 1 . The low DF for $\mathrm{K}^{+}$, in particular, indicates the SuperLig ${ }^{\circledR}$ 644 resin was highly selective for cesium over $\mathrm{K}^{+}$. With the exception of $\mathrm{F}^{-}$, the DF for the anions was approximately 1 .

\subsection{CESIUM ELUATE PRODUCTS}

The cesium eluate composite products were analyzed at the completion of the elution step for each cycle. The chemical and radionuclide content are given in Tables 4.9. In Table 4.9, the average concentration of ${ }^{137} \mathrm{Cs}$ in the eluate products was $\sim 2 \times 10^{3} \mu \mathrm{Ci} / \mathrm{mL}$. The concentration of ${ }^{137} \mathrm{Cs}\left(8.89 \times 10^{2} \mu \mathrm{Ci} / \mathrm{mL}\right)$ in cycle \#6 was lower because of the large dilutions made in order to transfer sub-samples from the hot cell. The ${ }^{137} \mathrm{Cs}$ was dominant radionuclide in the cesium eluate product solutions. The ${ }^{137} \mathrm{Cs}$ was above required MRQ level, but other radionuclides ${ }^{60} \mathrm{Co},{ }^{154} \mathrm{Eu}$, and ${ }^{155} \mathrm{Eu}$ were not measured. The CST-treated samples of the composite eluate show that only $\mathrm{Cl}^{-}$and $\mathrm{NO}_{3}^{-}$were above detection (See Table 4.9; data in brackets). 
WSRC-TR-2003-00098, REVISION 0

SRT-RPP-2003-00026, REVISION 0

Table 4-7. Composition of Effluent Composite Product

\begin{tabular}{|c|c|c|c|c|c|}
\hline Radionuclides & Cycle \#1 & Cycle \#2 & Cycle \#3 & Cycle \#4 & Cycle \#5 \\
\hline${ }^{137} \mathrm{C}, \mu \mathrm{Ci} / \mathrm{mL}$ & $3.48 \mathrm{E}-04$ & $3.72 \mathrm{E}-03$ & $2.87 \mathrm{E}-03$ & $4.50 \mathrm{E}-03$ & $4.01 \mathrm{E}-03$ \\
\hline${ }^{99} \mathrm{Tc}, \mu \mathrm{Ci} / \mathrm{mL}$ & $3.66 \mathrm{E}-05$ & $5.95 \mathrm{E}-05$ & $4.20 \mathrm{E}-05$ & $3.73 \mathrm{E}-05$ & $2.94 \mathrm{E}-05$ \\
\hline${ }^{99} \mathrm{Tc}, \mu \mathrm{g} / \mathrm{L}(\mathrm{ICP}-\mathrm{MS})$ & $1.73 \mathrm{E}+02$ & $1.73 \mathrm{E}+02$ & $1.99 \mathrm{E}+02$ & $1.34 \mathrm{E}+02$ & $1.25 \mathrm{E}+02$ \\
\hline Total carbon, mg/L & $2.30 \mathrm{E}+03$ & $2.26 \mathrm{E}+03$ & $2.34 \mathrm{E}+03$ & $1.62 \mathrm{E}+04$ & $1.52 \mathrm{E}+04$ \\
\hline $\mathrm{TIC}$ & $1.01 \mathrm{E}+03$ & $9.18 \mathrm{E}+02$ & $1.08 \mathrm{E}+03$ & $1.51 \mathrm{E}+04$ & $1.41 \mathrm{E}+04$ \\
\hline TOC & $1.29 \mathrm{E}+03$ & $1.34 \mathrm{E}+03$ & $1.26 \mathrm{E}+03$ & $1.11 \mathrm{E}+03$ & $1.05 \mathrm{E}+03$ \\
\hline Total base, $\mathrm{M}$ & $2.79 \mathrm{E}+00$ & $2.83 \mathrm{E}+00$ & $2.79 \mathrm{E}+00$ & $2.88 \mathrm{E}+00$ & $2.83 \mathrm{E}+00$ \\
\hline Free $\mathrm{OH}^{-}, \mathrm{M}$ & $2.05 \mathrm{E}+00$ & $2.01 \mathrm{E}+00$ & $1.84 \mathrm{E}+00$ & $2.10 \mathrm{E}+00$ & $2.09 \mathrm{E}+00$ \\
\hline $\begin{array}{l}\text { wt. \% dissolved } \\
\text { solids }\end{array}$ & $3.15 \mathrm{E}+01$ & $3.22 \mathrm{E}+01$ & $3.24 \mathrm{E}+01$ & $\mathrm{~nm}$ & $\mathrm{~nm}$ \\
\hline specific gravity & $1.23 \mathrm{E}+00$ & $1.23 \mathrm{E}+00$ & $1.23 \mathrm{E}+00$ & $1.23 \mathrm{E}+00$ & $1.23 \mathrm{E}+00$ \\
\hline \multicolumn{6}{|l|}{ IC (anions), $M$} \\
\hline $\mathrm{Cl}-$ & $6.22 \mathrm{E}-02$ & $6.35 \mathrm{E}-02$ & $6.18 \mathrm{E}-02$ & $6.60 \mathrm{E}-02$ & $6.46 \mathrm{E}-02$ \\
\hline F- & $9.64 \mathrm{E}-03$ & $6.92 \mathrm{E}-03$ & $6.87 \mathrm{E}-03$ & $\mathrm{~nm}$ & $4.90 \mathrm{E}-03$ \\
\hline HCOO- & $1.31 \mathrm{E}-02$ & $6.74 \mathrm{E}-03$ & $7.09 \mathrm{E}-03$ & $1.15 \mathrm{E}-02$ & $1.15 \mathrm{E}-02$ \\
\hline NO3- & $1.35 \mathrm{E}+00$ & $1.28 \mathrm{E}+00$ & $1.22 \mathrm{E}+00$ & $1.32 \mathrm{E}+00$ & $1.25 \mathrm{E}+00$ \\
\hline NO2- & 8.97E-01 & $9.12 \mathrm{E}-01$ & $8.95 \mathrm{E}-01$ & $9.27 \mathrm{E}-01$ & $9.25 \mathrm{E}-01$ \\
\hline$(\mathrm{C} 2 \mathrm{O} 4) 2-$ & $2.11 \mathrm{E}-03$ & $1.93 \mathrm{E}-03$ & $1.84 \mathrm{E}-03$ & $1.92 \mathrm{E}-03$ & $2.14 \mathrm{E}-03$ \\
\hline PO4- & $2.42 \mathrm{E}-03$ & $1.96 \mathrm{E}-03$ & $2.04 \mathrm{E}-03$ & $2.38 \mathrm{E}-03$ & $2.73 \mathrm{E}-03$ \\
\hline SO4- & $1.65 \mathrm{E}-03$ & $1.39 \mathrm{E}-03$ & $1.30 \mathrm{E}-03$ & $1.17 \mathrm{E}-03$ & $1.43 \mathrm{E}-03$ \\
\hline
\end{tabular}

$\mathrm{nm}=$ not measured 
WSRC-TR-2003-00098, REVISION 0

SRT-RPP-2003-00026, REVISION 0

Table 4-7. Composition of Effluent Composite Product - continued

\begin{tabular}{|c|c|c|c|c|c|}
\hline Analytes & Cycle \#1 & Cycle \#2 & Cycle \#3 & Cycle \#4 & Cycle \#5 \\
\hline by ICP-AES & $\mu \mathrm{g} / \mathrm{mL}$ & $\mu \mathrm{g} / \mathrm{mL}$ & $\mu \mathrm{g} / \mathrm{mL}$ & $\mu \mathrm{g} / \mathrm{mL}$ & $\mu \mathrm{g} / \mathrm{mL}$ \\
\hline $\mathrm{Ag}$ & $3.57 \mathrm{E}-01$ & $3.79 \mathrm{E}-01$ & $4.12 \mathrm{E}-01$ & $2.98 \mathrm{E}-01$ & $3.33 \mathrm{E}-01$ \\
\hline $\mathrm{Al}$ & $1.37 \mathrm{E}+04$ & $1.40 \mathrm{E}+04$ & $1.40 \mathrm{E}+04$ & $1.15 \mathrm{E}+04$ & $1.17 \mathrm{E}+04$ \\
\hline $\mathrm{B}$ & $1.85 \mathrm{E}+01$ & $1.91 \mathrm{E}+01$ & $1.89 \mathrm{E}+01$ & $1.68 \mathrm{E}+01$ & $1.72 \mathrm{E}+01$ \\
\hline $\mathrm{Ba}$ & $5.38 \mathrm{E}-01$ & $5.82 \mathrm{E}-01$ & $5.80 \mathrm{E}-01$ & $\mathrm{~nm}$ & $\mathrm{~nm}$ \\
\hline $\mathrm{Ca}$ & $5.95 \mathrm{E}+00$ & $6.22 \mathrm{E}+00$ & $6.23 \mathrm{E}+00$ & $5.00 \mathrm{E}+00$ & $5.30 \mathrm{E}+00$ \\
\hline $\mathrm{Cd}$ & $9.82 \mathrm{E}-01$ & $1.07 \mathrm{E}+00$ & $1.03 \mathrm{E}+00$ & $7.84 \mathrm{E}-01$ & $8.20 \mathrm{E}-01$ \\
\hline $\mathrm{Ce}$ & $4.17 \mathrm{E}+00$ & $4.42 \mathrm{E}+00$ & $4.76 \mathrm{E}+00$ & $3.88 \mathrm{E}+00$ & $4.21 \mathrm{E}+00$ \\
\hline $\mathrm{Cr}$ & $3.73 \mathrm{E}+01$ & $4.32 \mathrm{E}+01$ & $4.16 \mathrm{E}+01$ & $3.54 \mathrm{E}+01$ & $3.68 \mathrm{E}+01$ \\
\hline $\mathrm{Cu}$ & $3.78 \mathrm{E}+00$ & $2.50 \mathrm{E}+00$ & $2.65 \mathrm{E}+00$ & $1.59 \mathrm{E}+00$ & $1.20 \mathrm{E}+00$ \\
\hline $\mathrm{Fe}$ & $1.45 \mathrm{E}+00$ & $1.77 \mathrm{E}+00$ & $1.80 \mathrm{E}+00$ & $1.58 \mathrm{E}+00$ & $1.86 \mathrm{E}+00$ \\
\hline $\mathrm{K}$ & $2.13 \mathrm{E}+04$ & $2.19 \mathrm{E}+04$ & $2.18 \mathrm{E}+04$ & $1.75 \mathrm{E}+04$ & $1.77 \mathrm{E}+04$ \\
\hline $\mathrm{La}$ & $7.75 \mathrm{E}-01$ & $7.92 \mathrm{E}-01$ & $8.54 \mathrm{E}-01$ & $5.84 \mathrm{E}-01$ & $6.10 \mathrm{E}-01$ \\
\hline $\mathrm{Mo}$ & $4.27 \mathrm{E}+01$ & $4.36 \mathrm{E}+01$ & $4.39 \mathrm{E}+01$ & $3.47 \mathrm{E}+01$ & $3.54 \mathrm{E}+01$ \\
\hline $\mathrm{Na}$ & $1.16 \mathrm{E}+05$ & $1.21 \mathrm{E}+05$ & $1.20 \mathrm{E}+05$ & $1.01 \mathrm{E}+05$ & $1.04 \mathrm{E}+05$ \\
\hline $\mathrm{Ni}$ & $2.46 \mathrm{E}+00$ & $2.53 \mathrm{E}+00$ & $2.35 \mathrm{E}+00$ & $2.19 \mathrm{E}+00$ & $2.16 \mathrm{E}+00$ \\
\hline $\mathrm{P}$ & $1.46 \mathrm{E}+02$ & $1.49 \mathrm{E}+02$ & $1.49 \mathrm{E}+02$ & $1.30 \mathrm{E}+02$ & $1.36 \mathrm{E}+02$ \\
\hline $\mathrm{Pb}$ & $1.50 \mathrm{E}+01$ & $1.62 \mathrm{E}+01$ & $1.56 \mathrm{E}+01$ & $1.30 \mathrm{E}+01$ & $1.38 \mathrm{E}+01$ \\
\hline $\mathrm{Sb}$ & $3.94 \mathrm{E}+01$ & $4.07 \mathrm{E}+01$ & $4.09 \mathrm{E}+01$ & $3.09 \mathrm{E}+01$ & $3.22 \mathrm{E}+01$ \\
\hline $\mathrm{Si}$ & $9.15 \mathrm{E}+01$ & $8.96 \mathrm{E}+01$ & $8.99 \mathrm{E}+01$ & $6.73 \mathrm{E}+01$ & $6.86 \mathrm{E}+01$ \\
\hline $\mathrm{Sn}$ & $7.70 \mathrm{E}+01$ & $7.91 \mathrm{E}+01$ & $7.89 \mathrm{E}+01$ & $6.02 \mathrm{E}+01$ & $6.16 \mathrm{E}+01$ \\
\hline $\mathrm{Sr}$ & $2.00 \mathrm{E}+00$ & $2.07 \mathrm{E}+00$ & $2.08 \mathrm{E}+00$ & $1.59 \mathrm{E}+00$ & $1.81 \mathrm{E}+00$ \\
\hline $\mathrm{Zr}$ & $4.58 \mathrm{E}+00$ & $4.69 \mathrm{E}+00$ & $4.85 \mathrm{E}+00$ & $3.98 \mathrm{E}+00$ & $4.08 \mathrm{E}+00$ \\
\hline $\mathrm{Hn}$ & $4.44 \mathrm{E}+00$ & $6.06 \mathrm{E}+00$ & $5.44 \mathrm{E}+00$ & $4.95 \mathrm{E}+00$ & $5.24 \mathrm{E}+00$ \\
\hline
\end{tabular}

$\mathrm{nm}=$ not measured 
WSRC-TR-2003-00098, REVISION 0

SRT-RPP-2003-00026, REVISION 0

Table 4-8. Measured DF for Analytes

\begin{tabular}{|c|c|c|c|c|c|}
\hline Radionuclides & Cycle \#1 & Cycle \#2 & Cycle \#3 & Cycle \#4 & Cycle \#5 \\
\hline${ }^{137} \mathrm{Cs}$ & $5.03 \mathrm{E}+05$ & $4.71 \mathrm{E}+04$ & $6.10 \mathrm{E}+04$ & $3.89 \mathrm{E}+04$ & $4.27 \mathrm{E}+04$ \\
\hline${ }^{99} \mathrm{Tc}$ & $1.81 \mathrm{E}+03$ & $1.11 \mathrm{E}+03$ & $1.57 \mathrm{E}+03$ & $1.77 \mathrm{E}+03$ & $2.25 \mathrm{E}+03$ \\
\hline \multicolumn{6}{|l|}{ Metals } \\
\hline $\mathrm{Al}$ & 0.94 & 0.91 & 0.91 & 1.12 & 1.09 \\
\hline $\mathrm{K}$ & 1.10 & 1.07 & 1.08 & 1.34 & 1.32 \\
\hline $\mathrm{Na}$ & 1.01 & 0.97 & 0.98 & 1.16 & 1.13 \\
\hline \multicolumn{6}{|l|}{ Anions } \\
\hline $\mathrm{Cl}^{-}$ & 1.12 & 1.09 & 1.12 & 1.05 & 1.07 \\
\hline $\mathrm{F}^{-}$ & 1.47 & 2.05 & 2.07 & $\mathrm{Nm}$ & 2.90 \\
\hline $\mathrm{NO}_{3}$ & 1.16 & 1.22 & 1.28 & 1.18 & 1.25 \\
\hline $\mathrm{NO}_{2}$ & 1.02 & 1.00 & 1.02 & 0.98 & 0.99 \\
\hline TOC & $\mathrm{nm}$ & $\mathrm{nm}$ & $\mathrm{nm}$ & 0.81 & 0.77 \\
\hline
\end{tabular}

$\mathrm{nm}=$ not measured

Table 4-9. Composition of Cesium Eluate Composite Products

\begin{tabular}{|c|c|c|c|c|c|c|c|}
\hline Radionuclides & Cycle -1 & Cycle -2 & Cycle -3 & Cycle -4 & Cycle -5 & Cycle -6 & MRQ \\
\hline${ }^{137} \mathrm{Cs}, \mu \mathrm{Ci} / \mathrm{mL}$ & $1.74 \mathrm{E}+03$ & $2.19 \mathrm{E}+03$ & $2.06 \mathrm{E}+03$ & $2.34 \mathrm{E}+03$ & $1.59 \mathrm{E}+03$ & $8.89 \mathrm{E}+02$ & $9.00 \mathrm{E}+00$ \\
\hline${ }^{99} \mathrm{Tc}, \mu \mathrm{Ci} / \mathrm{mL}$ & $1.64 \mathrm{E}-03$ & $2.93 \mathrm{E}-03$ & $4.07 \mathrm{E}-03$ & $1.02 \mathrm{E}-02$ & $1.69 \mathrm{E}-03$ & $2.27 \mathrm{E}-03$ & $1.50 \mathrm{E}-03$ \\
\hline${ }^{99} \mathrm{Tc}, \mu \mathrm{g} / \mathrm{L}$ (ICP-MS) & $2.29 \mathrm{E}+02$ & $2.75 \mathrm{E}+02$ & $2.37 \mathrm{E}+02$ & $3.00 \mathrm{E}+02$ & $2.10 \mathrm{E}+02$ & $\mathrm{~nm}$ & -- \\
\hline${ }^{238} \mathrm{U}, \mu \mathrm{g} / \mathrm{L}(\mathrm{ICP}-\mathrm{MS})$ & $6.65 \mathrm{E}+01$ & $7.65 \mathrm{E}+01$ & $8.10 \mathrm{E}+01$ & $1.63 \mathrm{E}+02$ & $6.55 \mathrm{E}+01$ & $\mathrm{~nm}$ & -- \\
\hline Total carbon, $\mathrm{mg} / \mathrm{L}$ & $1.54 \mathrm{E}+03$ & $1.24 \mathrm{E}+03$ & $3.78 \mathrm{E}+03$ & $1.19 \mathrm{E}+03$ & $7.88 \mathrm{E}+02$ & $\mathrm{~nm}$ & -- \\
\hline $\mathrm{TIC}, \mu \mathrm{g} / \mathrm{mL}$ & $<2.61 \mathrm{E}+02$ & $<2.71 \mathrm{E}+02$ & $<3.78 \mathrm{E}+03$ & $<2.49 \mathrm{E}+02$ & $<2.58 \mathrm{E}+02$ & $\mathrm{~nm}$ & $1.50 \mathrm{E}+02$ \\
\hline $\mathrm{TOC}, \mu \mathrm{g} / \mathrm{L}$ & $1.54 \mathrm{E}+03$ & $1.24 \mathrm{E}+03$ & $3.78 \mathrm{E}+03$ & $1.19 \mathrm{E}+03$ & $7.88 \mathrm{E}+02$ & $\mathrm{~nm}$ & $1.50 \mathrm{E}+03$ \\
\hline IC (anions), $\mathrm{M}$ & Cycle -1 & Cycle -2 & Cycle -3 & Cycle -4 & Cycle -5 & Cycle -6 & MRQ \\
\hline $\mathrm{Cl}-$ & $\begin{array}{l}<1.47 \mathrm{E}-02 \\
(1.68 \mathrm{E}-02)\end{array}$ & $\begin{array}{l}<1.53 \mathrm{E}-02 . \\
(1.79 \mathrm{E}-02)\end{array}$ & $\begin{array}{l}<1.51 \mathrm{E}-02, \\
(1.85 \mathrm{E}-02)\end{array}$ & $\begin{array}{l}<1.47 \mathrm{E}-02 \\
(1.71 \mathrm{E}-02)\end{array}$ & $\begin{array}{l}<1.45 \mathrm{E}-02, \\
(1.70 \mathrm{E}-02)\end{array}$ & $\begin{array}{l}<1.56 \mathrm{E}-02 \\
(1.72 \mathrm{E}-02)\end{array}$ & $8.46 \mathrm{E}-03$ \\
\hline F- & $<2.75 \mathrm{E}-02$ & $<2.85 \mathrm{E}-02$ & $<2.82 \mathrm{E}-02$ & $<2.75 \mathrm{E}-02$ & $<2.71 \mathrm{E}-02$ & $<2.91 \mathrm{E}-02$ & $7.89 \mathrm{E}-03$ \\
\hline HCOO- & $<5.51 \mathrm{E}-02$ & $>6.02 \mathrm{E}-02$ & $<5.96 \mathrm{E}-02$ & $<5.53 \mathrm{E}-02$ & $<5.72 \mathrm{E}-02$ & $<6.13 \mathrm{E}-02$ & -- \\
\hline NO3- & $\begin{array}{l}\text { 4.48E-01, } \\
(8.74 \mathrm{E}-01)\end{array}$ & $\begin{array}{c}4.29 \mathrm{E}-01 \\
(8.87 \mathrm{E}-01)\end{array}$ & $\begin{array}{l}\text { 7.92E-01, } \\
(8.85 \mathrm{E}-01)\end{array}$ & $\begin{array}{c}6.31 \mathrm{E}-01 \\
(8.90 \mathrm{E}-01)\end{array}$ & $\begin{array}{c}\text { 4.61E-01, } \\
(8.74 \mathrm{E}-01)\end{array}$ & $\begin{array}{c}2.89 \mathrm{E}-01 \\
(8.82 \mathrm{E}-01)\end{array}$ & 4.69E-02 \\
\hline NO2- & $<5.68 \mathrm{E}-02$ & $<5.89 \mathrm{E}-02$ & $<1.02 \mathrm{E}-01$ & $<5.41 \mathrm{E}-02$ & $<5.60 \mathrm{E}-02$ & $<6.00 \mathrm{E}-02$ & $6.52 \mathrm{E}-02$ \\
\hline$(\mathrm{C} 2 \mathrm{O} 4) 2-$ & $<2.97 \mathrm{E}-02$ & $<3.08 \mathrm{E}-02$ & $<3.05 \mathrm{E}-02$ & $<2.83 \mathrm{E}-02$ & $<2.93 \mathrm{E}-02$ & $<3.12 \mathrm{E}-02$ & -- \\
\hline PO4- & $<2.75 \mathrm{E}-02$ & $<2.86 \mathrm{E}-02$ & $<2.82 \mathrm{E}-02$ & $<2.62 \mathrm{E}-02$ & $<2.71 \mathrm{E}-02$ & $<2.91 \mathrm{E}-02$ & $2.63 \mathrm{E}-02$ \\
\hline SO4- & $<1.36 \mathrm{E}-02$ & $<1.41 \mathrm{E}-02$ & $<1.40 \mathrm{E}-02$ & $<1.30 \mathrm{E}-02$ & $<1.34 \mathrm{E}-02$ & $<1.43 \mathrm{E}-02$ & $2.40 \mathrm{E}-02$ \\
\hline
\end{tabular}

Dashes (--) indicate no MRQ was specified. 
WSRC-TR-2003-00098, REVISION 0

SRT-RPP-2003-00026, REVISION 0

Table 4-9. Composition of Cesium Eluate Composite Products - continued

\begin{tabular}{|c|c|c|c|c|c|c|c|}
\hline Analytes by & Cycle -1 & Cycle -2 & Cycle -3 & Cycle -4 & Cycle -5 & Cycle -6 & MRQ \\
\hline ICP-AES & $\mu \mathrm{g} / \mathrm{mL}$ & $\mu \mathrm{g} / \mathrm{mL}$ & $\mu \mathrm{g} / \mathrm{mL}$ & $\mu g / m L$ & $\mu g / m L$ & $\mu g / m L$ & $\mu \mathrm{g} / \mathrm{mL}$ \\
\hline $\mathrm{Ag}$ & $<4.18 \mathrm{E}+01$ & $<4.34 \mathrm{E}+01$ & $<4.29 \mathrm{E}+01$ & $<3.97 \mathrm{E}+01$ & $<4.12 \mathrm{E}+01$ & $<4.35 \mathrm{E}+01$ & -- \\
\hline $\mathrm{Al}$ & $<2.98 \mathrm{E}+02$ & $<3.09 \mathrm{E}+02$ & $<3.06 \mathrm{E}+02$ & $<2.84 \mathrm{E}+02$ & $<2.94 \mathrm{E}+02$ & $<3.11 \mathrm{E}+02$ & $7.50 \mathrm{E}+01$ \\
\hline B & $6.76 \mathrm{E}+02$ & $6.78 \mathrm{E}+02$ & $5.54 \mathrm{E}+02$ & $6.44 \mathrm{E}+02$ & $6.97 \mathrm{E}+02$ & $8.60 \mathrm{E}+02$ & -- \\
\hline $\mathrm{Ba}$ & $9.95 \mathrm{E}+01$ & $1.03 \mathrm{E}+02$ & $1.02 \mathrm{E}+02$ & $9.50 \mathrm{E}+01$ & $9.80 \mathrm{E}+01$ & $1.04 \mathrm{E}+02$ & $2.30 \mathrm{E}+00$ \\
\hline $\mathrm{Ca}$ & $<1.20 \mathrm{E}+02$ & $<1.15 \mathrm{E}+02$ & $<1.23 \mathrm{E}+02$ & $<1.15 \mathrm{E}+02$ & $<1.19 \mathrm{E}+02$ & $<1.26 \mathrm{E}+02$ & $1.50 \mathrm{E}+02$ \\
\hline $\mathrm{Cd}$ & $2.19 \mathrm{E}+01$ & $2.27 \mathrm{E}+01$ & $2.25 \mathrm{E}+01$ & $2.09 \mathrm{E}+01$ & $2.16 \mathrm{E}+01$ & $2.29 \mathrm{E}+01$ & $7.50 \mathrm{E}+00$ \\
\hline $\mathrm{Ce}$ & $3.03 \mathrm{E}+02$ & $3.59 \mathrm{E}+02$ & $3.11 \mathrm{E}+02$ & $2.68 \mathrm{E}+02$ & $2.82 \mathrm{E}+02$ & $1.47 \mathrm{E}+02$ & -- \\
\hline $\mathrm{Cr}$ & $3.13 \mathrm{E}+01$ & $3.25 \mathrm{E}+01$ & $3.22 \mathrm{E}+01$ & $2.99 \mathrm{E}+01$ & $3.09 \mathrm{E}+01$ & $3.27 \mathrm{E}+01$ & $1.50 \mathrm{E}+01$ \\
\hline $\mathrm{Cu}$ & $1.46 \mathrm{E}+02$ & $1.55 \mathrm{E}+02$ & $1.47 \mathrm{E}+02$ & $1.39 \mathrm{E}+02$ & $1.43 \mathrm{E}+02$ & $8.97 \mathrm{E}+01$ & -- \\
\hline $\mathrm{Fe}$ & $1.88 \mathrm{E}+01$ & $1.95 \mathrm{E}+01$ & $1.93 \mathrm{E}+01$ & $1.80 \mathrm{E}+01$ & $1.85 \mathrm{E}+01$ & $1.96 \mathrm{E}+01$ & $1.50 \mathrm{E}+02$ \\
\hline $\mathrm{Gd}$ & $<1.22 \mathrm{E}+02$ & $<1.27 \mathrm{E}+02$ & $<1.25 \mathrm{E}+02$ & $<1.17 \mathrm{E}+02$ & $<1.21 \mathrm{E}+02$ & $<1.28 \mathrm{E}+02$ & -- \\
\hline $\mathrm{K}$ & $<4.91 \mathrm{E}+03$ & $<5.09 \mathrm{E}+03$ & $<5.38 \mathrm{E}+03$ & $<4.68 \mathrm{E}+03$ & $<4.84 \mathrm{E}+03$ & $<5.12 \mathrm{E}+03$ & $7.50 \mathrm{E}+01$ \\
\hline $\mathrm{La}$ & $4.89 \mathrm{E}+01$ & $5.91 \mathrm{E}+01$ & $5.25 \mathrm{E}+01$ & $4.16 \mathrm{E}+01$ & $4.60 \mathrm{E}+01$ & $3.92 \mathrm{E}+01$ & $3.50 \mathrm{E}+01$ \\
\hline $\mathrm{Li}$ & $2.25 \mathrm{E}+02$ & $2.33 \mathrm{E}+02$ & $2.31 \mathrm{E}+02$ & $2.14 \mathrm{E}+02$ & $2.22 \mathrm{E}+02$ & $2.34 \mathrm{E}+02$ & -- \\
\hline $\mathrm{Mg}$ & $<2.77 \mathrm{E}+01$ & $<2.87 \mathrm{E}+01$ & $<2.84 \mathrm{E}+01$ & $<2.64 \mathrm{E}+01$ & $<2.73 \mathrm{E}+01$ & $<2.89 \mathrm{E}+01$ & $3.00 \mathrm{E}+02$ \\
\hline $\mathrm{Mn}$ & $<4.20 \mathrm{E}+00$ & $<4.30 \mathrm{E}+00$ & $<4.30 \mathrm{E}+00$ & $<4.00 \mathrm{E}+00$ & $<4.10 \mathrm{E}+00$ & $<4.35 \mathrm{E}+00$ & -- \\
\hline Mo & $<2.77 \mathrm{E}+02$ & $<2.87 \mathrm{E}+02$ & $<2.84 \mathrm{E}+02$ & $<2.64 \mathrm{E}+02$ & $<2.73 \mathrm{E}+02$ & $<2.89 \mathrm{E}+02$ & -- \\
\hline $\mathrm{Na}$ & $1.59 \mathrm{E}+03$ & $1.95 \mathrm{E}+03$ & $1.62 \mathrm{E}+03$ & $1.95 \mathrm{E}+03$ & $1.54 \mathrm{E}+03$ & $1.92 \mathrm{E}+03$ & $7.50 \mathrm{E}+01$ \\
\hline $\mathrm{Ni}$ & $7.05 \mathrm{E}+01$ & $7.31 \mathrm{E}+01$ & $7.23 \mathrm{E}+01$ & $6.72 \mathrm{E}+01$ & $6.95 \mathrm{E}+01$ & $7.35 \mathrm{E}+01$ & $3.00 \mathrm{E}+01$ \\
\hline $\mathrm{P}$ & $<3.60 \mathrm{E}+02$ & $<3.74 \mathrm{E}+02$ & $<3.70 \mathrm{E}+02$ & $<3.44 \mathrm{E}+02$ & $<3.56 \mathrm{E}+02$ & $<3.76 \mathrm{E}+02$ & $6.00 \mathrm{E}+02$ \\
\hline $\mathrm{Pb}$ & $<1.67 \mathrm{E}+02$ & $<1.73 \mathrm{E}+02$ & $<1.71 \mathrm{E}+02$ & $<1.59 \mathrm{E}+02$ & $<1.65 \mathrm{E}+02$ & $<1.74 \mathrm{E}+02$ & $3.00 \mathrm{E}+02$ \\
\hline $\mathrm{Sb}$ & $<1.97 \mathrm{E}+03$ & $<2.05 \mathrm{E}+03$ & $<2.02 \mathrm{E}+03$ & $<1.88 \mathrm{E}+03$ & $<1.95 \mathrm{E}+03$ & $<2.06 \mathrm{E}+03$ & -- \\
\hline $\mathrm{Si}$ & $<8.72 \mathrm{E}+01$ & $<9.05 \mathrm{E}+01$ & $<8.94 \mathrm{E}+01$ & $<8.32 \mathrm{E}+01$ & $<8.60 \mathrm{E}+01$ & $<9.09 \mathrm{E}+01$ & -- \\
\hline $\mathrm{Sn}$ & $3.32 \mathrm{E}+02$ & $4.47 \mathrm{E}+02$ & $3.55 \mathrm{E}+02$ & $3.89 \mathrm{E}+02$ & $3.52 \mathrm{E}+02$ & $2.45 \mathrm{E}+02$ & -- \\
\hline $\mathrm{Sr}$ & $3.97 \mathrm{E}+01$ & $4.12 \mathrm{E}+01$ & $4.07 \mathrm{E}+01$ & $3.79 \mathrm{E}+01$ & $3.91 \mathrm{E}+01$ & $4.14 \mathrm{E}+01$ & -- \\
\hline $\mathrm{Tc}$ & $<3.13 \mathrm{E}+01$ & $<3.25 \mathrm{E}+01$ & $<3.22 \mathrm{E}+01$ & $<2.99 \mathrm{E}+01$ & $<3.09 \mathrm{E}+01$ & $<3.27 \mathrm{E}+01$ & -- \\
\hline $\mathrm{Ti}$ & $<4.02 \mathrm{E}+01$ & $<4.17 \mathrm{E}+01$ & $<4.13 \mathrm{E}+01$ & $<3.83 \mathrm{E}+01$ & $<3.97 \mathrm{E}+01$ & $<4.19 \mathrm{E}+01$ & -- \\
\hline $\mathrm{U}$ & $<1.18 \mathrm{E}+03$ & $<1.23 \mathrm{E}+03$ & $<1.22 \mathrm{E}+03$ & $<1.13 \mathrm{E}+03$ & $<1.17 \mathrm{E}+03$ & $<1.24 \mathrm{E}+03$ & $6.00 \mathrm{E}+02$ \\
\hline $\mathrm{Zn}$ & $<1.67 \mathrm{E}+01$ & $<1.73 \mathrm{E}+01$ & $<1.72 \mathrm{E}+01$ & $<1.60 \mathrm{E}+01$ & $<1.65 \mathrm{E}+01$ & $<1.75 \mathrm{E}+01$ & -- \\
\hline $\mathrm{Zr}$ & $<1.19 \mathrm{E}+02$ & $<1.24 \mathrm{E}+02$ & $<1.22 \mathrm{E}+02$ & $<1.14 \mathrm{E}+02$ & $<1.18 \mathrm{E}+02$ & $<1.22 \mathrm{E}+02$ & -- \\
\hline
\end{tabular}

Dashes (--) indicate no MRQ was specified. 


\subsection{TECHNETIUM ELUATE PRODUCTS}

The technetium eluate composite products were analyzed to determine the composition of the chemical species and radionuclides and the results are shown in Table 4-10. The major radionuclide in the eluate products was ${ }^{99} \mathrm{Tc}$ with concentration with concentration in the range $3.6 \times 10^{-1}$ to $4.9 \times 10^{-1} \mu \mathrm{Ci} / \mathrm{mL}$. The concentrations of the metals (cations) were as expected. Sodium and potassium were dominant in the eluate products and their MRQs were met. The concentrations of the majority of the metals were below their MRQs. The dominant anions were $\mathrm{NO}_{3}{ }^{-}$and $\mathrm{NO}_{2}{ }^{-}$. The MRQs for the anions were not met.

Table 4-10. Composition of Technetium Eluate Composite Products

\begin{tabular}{|c|c|c|c|c|c|c|}
\hline Analyte & Cycle -1 & Cycle -2 & Cycle -3 & Cycle -4 & Cycle -5 & MRQ \\
\hline${ }^{137} \mathrm{Cs}, \mathrm{mCi} / \mathrm{mL}$ & $8.31 \mathrm{E}-05$ & $2.78 \mathrm{E}-04$ & $6.65 \mathrm{E}-03$ & $2.41 \mathrm{E}-04$ & $1.63 \mathrm{E}-02$ & $9.00 \mathrm{E}+00$ \\
\hline${ }^{99} \mathrm{Tc}, \mathrm{mCi} / \mathrm{mL}$ & $2.46 \mathrm{E}-01$ & $3.84 \mathrm{E}-01$ & $3.64 \mathrm{E}-01$ & $3.90 \mathrm{E}-01$ & $4.89 \mathrm{E}-01$ & $1.50 \mathrm{E}-03$ \\
\hline${ }^{99} \mathrm{Tc}, \mathrm{mg} / \mathrm{L}(\mathrm{ICP}-\mathrm{MS})$ & $1.47 \mathrm{E}+03$ & $2.11 \mathrm{E}+04$ & $2.05 \mathrm{E}+04$ & $2.21 \mathrm{E}+04$ & $\mathrm{~nm}$ & -- \\
\hline${ }^{238} \mathrm{U}, \mathrm{mg} / \mathrm{L}(\mathrm{ICP}-\mathrm{MS})$ & 3.6 & 8.8 & 23.4 & 29.1 & $\mathrm{~nm}$ & -- \\
\hline IC $(\mathbf{a n i o n s}), \mathbf{M}$ & & & & & & \\
\hline $\mathrm{Cl}-$ & $<5.64 \mathrm{E}-05$ & $3.33 \mathrm{E}-03$ & $1.69 \mathrm{E}-04$ & $5.36 \mathrm{E}-04$ & $\mathrm{~nm}$ & $8.46 \mathrm{E}-03$ \\
\hline F- & $<1.05 \mathrm{E}-04$ & $2.63 \mathrm{E}-04$ & $<1.05 \mathrm{E}-04$ & $<1.05 \mathrm{E}-04$ & $\mathrm{~nm}$ & $7.89 \mathrm{E}-03$ \\
\hline $\mathrm{HCOO}-$ & $<2.22 \mathrm{E}-04$ & $1.08 \mathrm{E}-03$ & $<2.22 \mathrm{E}-04$ & $<2.22 \mathrm{E}-04$ & $\mathrm{~nm}$ & -- \\
\hline NO3- & $3.39 \mathrm{E}-04$ & $8.73 \mathrm{E}-02$ & $4.33 \mathrm{E}-03$ & $3.18 \mathrm{E}-03$ & $\mathrm{~nm}$ & $4.69 \mathrm{E}-02$ \\
\hline NO2- & $1.85 \mathrm{E}-04$ & $4.42 \mathrm{E}-02$ & $3.20 \mathrm{E}-03$ & $2.38 \mathrm{E}-03$ & $\mathrm{~nm}$ & $6.52 \mathrm{E}-02$ \\
\hline$(\mathrm{C} 2 \mathrm{O} 4) 2-$ & $<1.14 \mathrm{E}-04$ & $1.02 \mathrm{E}-04$ & $<1.14 \mathrm{E}-04$ & $<1.14 \mathrm{E}-04$ & $\mathrm{~nm}$ & -- \\
\hline PO4- & $<1.05 \mathrm{E}-04$ & $8.95 \mathrm{E}-05$ & $<1.05 \mathrm{E}-04$ & $<1.05 \mathrm{E}-04$ & $\mathrm{~nm}$ & $2.63 \mathrm{E}-02$ \\
\hline SO4- & $<5.21 \mathrm{E}-04$ & $6.25 \mathrm{E}-05$ & $<5.21 \mathrm{E}-04$ & $<5.21 \mathrm{E}-04$ & $\mathrm{~nm}$ & $2.40 \mathrm{E}-02$ \\
\hline
\end{tabular}

$\mathrm{nm}=$ not measured

Dashes (--) indicate no MRQ was specified. 
WSRC-TR-2003-00098, REVISION 0

SRT-RPP-2003-00026, REVISION 0

Table 4-10. Composition of Technetium Eluate Composite Products - continued

\begin{tabular}{|c|c|c|c|c|c|c|}
\hline Analyte & Cycle -1 & Cycle -2 & Cycle -3 & Cycle -4 & Cycle -5 & MRQ \\
\hline ICP-ES & $\mu \mathrm{g} / \mathrm{mL}$ & $\mu \mathrm{g} / \mathrm{mL}$ & $\mu \mathrm{g} / \mathrm{mL}$ & $\mu \mathrm{g} / \mathrm{mL}$ & $\mu \mathrm{g} / \mathrm{mL}$ & $\mu \mathrm{g} / \mathrm{mL}$ \\
\hline $\mathrm{Ag}$ & $<0.160$ & $<0.160$ & $<0.160$ & $<0.160$ & $<0.160$ & -- \\
\hline $\mathrm{Al}$ & 2.0 & 614 & 45.4 & 30.9 & 34 & $7.50 \mathrm{E}+01$ \\
\hline B & 6.88 & 3.31 & 4.51 & 5.37 & 2.03 & -- \\
\hline $\mathrm{Ba}$ & $<0.380$ & $<0.380$ & $<0.380$ & $<0.428$ & $<0.380$ & $2.30 \mathrm{E}+00$ \\
\hline $\mathrm{Be}$ & $<0.020$ & 0.069 & 0.035 & $<0.030$ & 0.055 & $1.50 \mathrm{E}+02$ \\
\hline $\mathrm{Ca}$ & $<0.460$ & $<0.460$ & $<0.460$ & $<0.518$ & $<0.460$ & $7.50 \mathrm{E}+00$ \\
\hline $\mathrm{Cd}$ & $<0.084$ & $<0.084$ & $<0.084$ & $<0.095$ & $<0.084$ & -- \\
\hline $\mathrm{Ce}$ & 1.0 & 1.61 & 1.25 & 0.964 & $<0.540$ & $1.50 \mathrm{E}+01$ \\
\hline $\mathrm{Cr}$ & $<0.120$ & 1.84 & $<0.120$ & $<0.135$ & $<0.120$ & -- \\
\hline $\mathrm{Cu}$ & 0.25 & 0.298 & 0.24 & 0.263 & 0.319 & $1.50 \mathrm{E}+02$ \\
\hline $\mathrm{Fe}$ & 0.43 & 0.459 & 0.208 & 0.187 & $<0.072$ & -- \\
\hline K & 32.05 & 1220 & 96.6 & 82 & 100.4 & $7.50 \mathrm{E}+01$ \\
\hline $\mathrm{La}$ & $<0.144$ & 0.221 & 0.168 & $<0.162$ & $<0.144$ & $3.50 \mathrm{E}+01$ \\
\hline $\mathrm{Li}$ & $<0.860$ & $<0.860$ & $<0.860$ & $<0.970$ & $<0.860$ & -- \\
\hline $\mathrm{Mg}$ & $<0.106$ & $<0.106$ & $<0.106$ & $<0.120$ & $<0.106$ & $3.00 \mathrm{E}+02$ \\
\hline $\mathrm{Mn}$ & $<0.016$ & $<0.016$ & $<0.016$ & $<0.018$ & $<0.016$ & -- \\
\hline Mo & $<1.06$ & 2.29 & $<1.06$ & $<1.20$ & $<1.06$ & -- \\
\hline $\mathrm{Na}$ & 89 & 5770 & 461 & 364 & 416 & $7.50 \mathrm{E}+01$ \\
\hline $\mathrm{Ni}$ & $<0.270$ & $<0.270$ & $<0.270$ & $<0.304$ & $<0.270$ & $3.00 \mathrm{E}+01$ \\
\hline$P$ & 5.6 & 13.6 & 6.41 & 6.31 & $<1.38$ & $6.00 \mathrm{E}+02$ \\
\hline $\mathrm{Pb}$ & $<0.638$ & $<0.638$ & $<0.638$ & $<0.718$ & $<0.638$ & $3.00 \mathrm{E}+02$ \\
\hline $\mathrm{S}$ & $<2.74$ & 11.2 & $<2.74$ & $<3.09$ & $<2.74$ & -- \\
\hline $\mathrm{Sb}$ & $<7.56$ & $<7.56$ & $<7.56$ & $<8.51$ & $<7.56$ & -- \\
\hline $\mathrm{Si}$ & 10.89 & 17.8 & 7.71 & 6.07 & 4.6 & - \\
\hline $\mathrm{Sn}$ & $<0.900$ & 4.01 & $<0.900$ & $<1.02$ & $<0.900$ & -- \\
\hline $\mathrm{Sr}$ & $<0.152$ & $<0.152$ & $<0.152$ & $<0.171$ & $<0.152$ & - \\
\hline $\mathrm{Ti}$ & $<0.154$ & $<0.154$ & $<0.154$ & $<0.174$ & $<1.54$ & -- \\
\hline $\mathrm{U}$ & $<4.54$ & $<4.54$ & $<4.54$ & $<4.61$ & $<4.54$ & $6.00 \mathrm{E}+02$ \\
\hline $\mathrm{Zn}$ & $<0.064$ & 0.206 & $<0.064$ & $<0.072$ & $<0.064$ & -- \\
\hline $\mathrm{Zr}$ & $<0.456$ & $<0.456$ & $<0.456$ & $<0.463$ & $<0.456$ & -- \\
\hline
\end{tabular}

Dashes (--) indicate no MRQ was specified. 


\section{WSRC-TR-2003-00098, REVISION 0 SRT-RPP-2003-00026, REVISION 0}

\subsection{SPENT RESIN ANALYSIS}

The spent resins from the cesium and technetium ion exchange lead columns were analyzed to determine the concentrations of radionuclide and toxic metals that may be left on the resin after multiple load/elute/ regenerate cycles. The amount of SuperLig ${ }^{\circledR} 644$ resin initially added to the cesium lead column was $5.1562 \mathrm{~g}$ of $\mathrm{H}$ - form resin. After six cycles, the lead column was eluted with $24 \mathrm{BV}$ of $0.5 \underline{\mathrm{M}} \mathrm{HNO} 3$, and then rinsed with excess amount of DI water. The resin was slurred from the column with DI water into a Nalgene filter unit, where a house vacuum (20-inch water) was used to remove standing water. The resin was allowed to dry for two weeks to a constant mass of $3.11 \mathrm{~g}$.

Following the processing of the AW-101 sample, the technetium lead column was eluted with $28 \mathrm{BV}$ of DI water at $65^{\circ} \mathrm{C}$. The amount of SuperLig ${ }^{\circledR} 639$ resin initially added to the technetium lead column was $7.3659 \mathrm{~g}(12 \mathrm{~mL}$ on a wet-basis). Since this material does not exhibit an appreciable change in volume when in contact with the various processing solutions, the volume of resin was unchanged. After elution, the SuperLig ${ }^{\circledR} 639$ resin was slurried into a Nalgene filter unit under house vacuum (20-inch water) and the standing water was removed. The resin was allowed to dry in the hood for two weeks. The dry spent resin was stored in glass vial and submitted to SRTC Analytical Development Section (ADS) for analysis.

The analyses performed on each sample of the spent resins included Toxicity Characterization Leaching Procedure (TCLP), microwave dissolution of spent resin samples, ICP-AES analysis (metals), GEA analysis (radionuclide), and chemical separation and beta counting $\left({ }^{99} \mathrm{Tc},{ }^{90} \mathrm{Sr}\right)$. The concentrations of arsenic, selenium and mercury were measured by Atomic Absorption Spectrometry.

The Toxicity Characteristic Leaching Procedure (TCLP) was performed in SRTC to analyze the spent resins for hazardous constituents. The TCLP is a standard procedure accepted by Environmental Protection Agency to determine if the solid form of waste is hazardous. The EPA standard method (SW-376) requires a minimum 50-gram sample to perform the procedure. $^{23}$ Due to small size of the resin samples available, SRTC employed a modified TCLP test. A small portion (1.0 gram) of each spent resin sample was weighed in $25-\mathrm{mL}$ plastic vials containing $20 \mathrm{~mL}$ of TCLP Extraction Fluid 1, then the vials were capped. TCLP Extraction Fluid 1 was prepared by adding $5.7 \mathrm{~mL}$ glacial acetic acid to $500 \mathrm{~mL}$ deionized water, followed by adding $64.3 \mathrm{~mL}$ of $1.0 \mathrm{M} \mathrm{NaOH}$, and diluting the solution to a volume of exactly $1 \mathrm{~L}$. The vials were placed in an extractor vessel and rotated end-over-end at $30 \pm 2 \mathrm{rpm}$ for 18 hours. The solution was then filtered through a 0.7 micron porosity fiberglass filter and the filtrate transferred to sample bottles for analysis. 
Small portions (1.0 gram) of each sample of SuperLig ${ }^{\circledR} 644$ and 639 resins were subjected to microwave dissolution, and an aliquot of each dissolved sample was analyzed by ICP-AES. Gamma analysis was performed on an aliquot of each dissolved samples to determine ${ }^{137} \mathrm{Cs}$, ${ }^{60} \mathrm{Co},{ }^{154} \mathrm{Eu}$, and ${ }^{155} \mathrm{Eu}$ using a high purity germanium detector. The ${ }^{99} \mathrm{Tc}$ concentration was determined by chemical separation, followed by beta counting, using small aliquots of the dissolution samples. Total alpha and beta concentrations were measured by rad screen.

Aliquots of the dissolved samples were wet-ashed with a sodium persulfate/silver nitrate oxidation in conjunction with concentrated sulfuric acid. The carbon dioxide emitted was absorbed with Packard Instruments Carbosorb E. The Carbosorb E was then slurred into Ultima Gold AB, and analyzed by liquid scintillation analysis for C-14. A laboratory control blank solution, spiked with a C-14 standard, was run in duplicate, in parallel with the samples to determine $\mathrm{C}-14$ recoveries, the average of which were applied to the sample C-14 Liquid Scintillation Counting (LSC) results to quantify the C-14 concentrations in the samples. A blank solution was also run through the process to ensure no cross contamination existed at the laboratory level.

An aliquot of each dissolved sample was spiked with stable iodide and was subjected to a silver iodide precipitation method to separate any iodide in the matrix from other radionuclides. A blank DI water sample was analyzed along with the batch. The precipitates were analyzed for I-129 activity with a low energy HPGe gamma spectroscopy detector. After the gamma analyses, the precipitates were analyzed by neutron activation analysis (NAA) to determine the levels of stable iodide carrier in the precipitates. The recoveries of the iodide carrier were used to correct the gamma spectroscopy results for the I-129 recoveries.

Strontium-90 separation and analysis was performed using another pair of aliquots from the dissolved samples. The separation was performed using an Eichrom Sr-Spec based extraction procedure. Once the extraction was completed for the aliquots, the resultant Sr-90 containing extracts were mixed with liquid scintillation cocktail and counted in the ADS Radiochemistry Counting Facility. The samples were counted on a Packard Instruments liquid scintillation counter.

Plutonium separation and analysis were performed using an aliquot from each dissolved samples. An aliquot of each sample was initially spiked with a Pu-239 tracer. A second aliquot of sample was analyzed along with the spiked sample. All of the plutonium in the samples was reduced once using hydroxylamine. An anion complexing reagent (aluminum nitrate) was then added, and the solutions were oxidized with $4 \underline{\mathrm{M}}$ sodium nitrite. The plutonium was then extracted from the matrix using a thenoyltrifluoroacetone (TTA) solution. The TTA layer was mounted on a counting dish, the mount was then analyzed by alpha spectroscopy. 
The results of the radionuclide concentrations of SuperLig ${ }^{\circledR} 644$ and 639 spent resins and the WTP specified minimum reportable quantities (MRQ) are given in Table 4-11. Specifically listed are the isotope, the analysis method and isotopic activity. The results given in the table show that ${ }^{60} \mathrm{Co},{ }^{137} \mathrm{Cs}$, and ${ }^{99} \mathrm{Tc}$ were dominant among the radionuclides accumulated on the spent SuperLig ${ }^{\circledR} 644$ resins. The ${ }^{137} \mathrm{Cs}$ accumulated on the spent resin was $20 \mu \mathrm{Ci} / \mathrm{g}$ by GEA measurement; the beta activity measured $23.5 \mu \mathrm{Ci} / \mathrm{g}$. These values compare very well with the results $(20 \mu \mathrm{Ci} / \mathrm{g})$ previously reported by Kurath. ${ }^{21}$ As expected, ${ }^{99} \mathrm{Tc}$ was dominant on the spent SuperLig ${ }^{\circledR} 639$ spent resin with a value of $3.6 \times 10^{-1} \mu \mathrm{Ci} / \mathrm{g}$. The ${ }^{137} \mathrm{Cs}$ and total beta activity found on SuperLig ${ }^{\circledR} 639$ spent resin were very small, suggesting the dose to the resin was not significant. The concentration of plutonium isotopes on spent resin (SuperLig $\left.{ }^{\circledR} 644\right)$ was set by total alpha $\left(1.36 \times 10^{-1} \mu \mathrm{Ci} / \mathrm{g}\right)$. The analytes measured above the minimum reportable quantities (MRQs) for cesium spent resin (SuperLig ${ }^{\circledR} 644$ ) were ${ }^{60} \mathrm{Co},{ }^{137} \mathrm{Cs},{ }^{99} \mathrm{Tc}$, ${ }^{238} \mathrm{Pu}$, and ${ }^{241} \mathrm{Pu}$. The only analyte above MRQ for technetium spent resin (SuperLig ${ }^{\circledR} 639$ ) was ${ }^{99}$ Tc.

Table 4-11. Radionuclide Accumulation in Spent Resins

\begin{tabular}{|c|c|c|c|c|}
\hline Analyte & Method & $\begin{array}{c}\text { SL-644 } \\
\mu \text { Ci/g resin* }\end{array}$ & $\begin{array}{c}\text { SL-639 } \\
\mu \text { Ci/g resin* }\end{array}$ & $\begin{array}{c}\text { MRQ } \\
\mu \text { Ci/g resin* }\end{array}$ \\
\hline${ }^{60} \mathrm{Co}$ & GEA & $8.24 \mathrm{E}-01$ & $<1.91 \mathrm{E}-02$ & $1.2 \mathrm{E}-01$ \\
\hline${ }^{137} \mathrm{Cs}$ & $\mathrm{GEA}$ & $2.00 \mathrm{E}+01$ & $<3.10 \mathrm{E}-02$ & $1.0 \mathrm{E}-02$ \\
\hline${ }^{154} \mathrm{Eu}$ & $\mathrm{GEA}$ & $\mathrm{nm}$ & $\mathrm{nm}$ & $3.0 \mathrm{E}-01$ \\
\hline${ }^{155} \mathrm{Eu}$ & $\mathrm{GEA}$ & $\mathrm{nm}$ & $\mathrm{nm}$ & $6.0 \mathrm{E}+00$ \\
\hline $\mathrm{Pu}^{238}$ & $\mathrm{Pu}$ TTA & $3.40 \mathrm{E}-02$ & $7.79 \mathrm{E}-04$ & $1.0 \mathrm{E}-02$ \\
\hline $\mathrm{Pu}^{239 / 240}$ & $\mathrm{Pu}$ TTA & $6.67 \mathrm{E}-03$ & $2.03 \mathrm{E}-03$ & $3.0 \mathrm{E}-02$ \\
\hline${ }^{\mathrm{Pu}}{ }^{241}$ & Pu-241 LSC & $3.39 \mathrm{E}-02$ & $\mathrm{~nm}$ & $3.0 \mathrm{E}-02$ \\
\hline${ }^{90} \mathrm{Sr}$ & Beta LSC & $\mathrm{nm}$ & $\mathrm{nm}$ & $1.50 \mathrm{E}-04$ \\
\hline${ }^{99} \mathrm{Tc}$ & Beta LSC & $1.41 \mathrm{E}-01$ & $3.65 \mathrm{E}-01$ & $6.0 \mathrm{E}-04$ \\
\hline${ }^{14} \mathrm{C}$ & Beta LSC & $<2.60 \mathrm{E}-04$ & $\mathrm{~nm}$ & $\mathrm{~nm}$ \\
\hline${ }^{129} \mathrm{I}$ & GEA & $<1.00 \mathrm{E}-05$ & $\mathrm{~nm}$ & $\mathrm{~nm}$ \\
\hline Total alpha & Rad screen & $1.36 \mathrm{E}-01$ & $3.14 \mathrm{E}-03$ & $\mathrm{~nm}$ \\
\hline Total beta & Rad screen & $2.35 \mathrm{E}+01$ & $4.86 \mathrm{E}-01$ & $\mathrm{~nm}$ \\
\hline
\end{tabular}

*H- form (After extended elution and rinse with DI water, the resin was dried in air for two weeks.) 
The results of the TCLP analyses of SuperLig ${ }^{\circledR} 644$ and 639 spent resins are shown in Table 4-12. The table contains the Resource Conservation and Recovery Act (RCRA) limits for hazardous constituents. The results show that the RCRA metals for each spent resin were below the hazardous limit. Since SRTC is not a certified laboratory, the TCLP results are to augment the process knowledge for RPP-WTP in an effort to determine disposal alternatives for spent resins generated during the operation of the WTP plant.

Table 4-12. TCLP Results for Spent Resins

\begin{tabular}{|c|c|c|c|c|}
\hline Analyte & SL644 & SL639 & Limits & Units \\
\hline $\mathrm{As}$ & $<0.025$ & $<0.025$ & 5 & $\mathrm{mg} / \mathrm{L}$ \\
\hline $\mathrm{Ba}$ & 0.383 & 0.468 & 100 & $\mathrm{mg} / \mathrm{L}$ \\
\hline $\mathrm{Cd}$ & $<0.042$ & $<0.042$ & 1 & $\mathrm{mg} / \mathrm{L}$ \\
\hline $\mathrm{Cr}$ & $<0.060$ & $<0.060$ & 5 & $\mathrm{mg} / \mathrm{L}$ \\
\hline $\mathrm{Pb}$ & $<0.319$ & $<0.319$ & 5 & $\mathrm{mg} / \mathrm{L}$ \\
\hline $\mathrm{Hg}$ & $<0.110$ & $<0.110$ & 0.2 & $\mathrm{mg} / \mathrm{L}$ \\
\hline $\mathrm{Se}$ & $<0.025$ & $<0.025$ & 1 & $\mathrm{mg} / \mathrm{L}$ \\
\hline $\mathrm{Ag}$ & $<0.080$ & $<0.080$ & 5 & $\mathrm{mg} / \mathrm{L}$ \\
\hline
\end{tabular}

The results for spent resin (solids) analysis by ICP-AES, along with specified MRQ are shown in Table 4-13. The data provided in the table are based on mass of analyte accumulated on dry resin samples. The metals above their MRQ that were found on SuperLig ${ }^{\circledR} 644$ and 639 resin samples were $\mathrm{Al}, \mathrm{Cr}, \mathrm{Na}, \mathrm{K}$, and $\mathrm{Ni}$. The presence of $\mathrm{K}, \mathrm{Na}$, and $\mathrm{Cr}$ on SuperLig ${ }^{\circledR} 644$ and 639 samples was expected since the resins are known to have some affinity for these metals. Other metals found on the resin samples above their detection limits were $\mathrm{Ag}, \mathrm{Ca}, \mathrm{Ce}, \mathrm{Cu}, \mathrm{Fe}, \mathrm{Mg}, \mathrm{Si}, \mathrm{Sr}$, and $\mathrm{Zn}$. The presence of $\mathrm{Si}$ (silicon) is likely from leaching of glassware used in sample handling and preparation. 
WSRC-TR-2003-00098, REVISION 0

SRT-RPP-2003-00026, REVISION 0

Table 4-13. ICP-AES Results of Spent Resin Dissolution Samples

\begin{tabular}{|c|c|c|c|}
\hline $\begin{array}{l}\text { Analyte } \\
\text { ICP-AES }\end{array}$ & $\begin{array}{c}\text { SL644 } \\
\mathrm{mg} / \mathrm{g}\end{array}$ & $\begin{array}{c}\text { SL639 } \\
\mathrm{mg} / \mathrm{g}\end{array}$ & $\begin{array}{c}\text { MRQ* } \\
\mathrm{mg} / \mathrm{g}\end{array}$ \\
\hline $\mathrm{Ag}$ & $2.4 \mathrm{E}+01$ & $<6.75$ & -- \\
\hline $\mathrm{Al}$ & $1.8 \mathrm{E}+02$ & $1.3 \mathrm{E}+02$ & $7.5 \mathrm{E}+01$ \\
\hline B & $<22.5$ & $<23.6$ & -- \\
\hline $\mathrm{Ba}$ & $<15.2$ & $<16.0$ & $2.3 \mathrm{E}+01$ \\
\hline $\mathrm{Ca}$ & $6.0 \mathrm{E}+01$ & $4.5 \mathrm{E}+01$ & $1.5 \mathrm{E}+02$ \\
\hline $\mathrm{Cd}$ & $<3.37$ & $<3.54$ & $7.5 \mathrm{E}+00$ \\
\hline $\mathrm{Ce}$ & $4.6 \mathrm{E}+01$ & $4.0 \mathrm{E}+01$ & -- \\
\hline $\mathrm{Cr}$ & $5.7 \mathrm{E}+02$ & $3.9 \mathrm{E}+01$ & $1.5 \mathrm{E}+01$ \\
\hline $\mathrm{Cu}$ & $8.7 \mathrm{E}+01$ & $1.7 \mathrm{E}+02$ & -- \\
\hline $\mathrm{Fe}$ & $1.1 \mathrm{E}+02$ & $1.5 \mathrm{E}+02$ & $1.5 \mathrm{E}+02$ \\
\hline $\mathrm{Gd}$ & $<18.8$ & $<19.7$ & -- \\
\hline K & $7.5 \mathrm{E}+02$ & $7.9 \mathrm{E}+02$ & $7.5 \mathrm{E}+01$ \\
\hline $\mathrm{La}$ & $<5.78$ & $<6.07$ & $3.5 \mathrm{E}+01$ \\
\hline $\mathrm{Li}$ & $<34.5$ & $<36.3$ & -- \\
\hline $\mathrm{Mg}$ & $6.1 \mathrm{E}+01$ & $1.9 \mathrm{E}+02$ & $3.0 \mathrm{E}+02$ \\
\hline $\mathrm{Mn}$ & $<0.642$ & $<0.675$ & -- \\
\hline Mo & $<42.5$ & $<44.7$ & -- \\
\hline $\mathrm{Na}$ & $2.8 \mathrm{E}+03$ & $1.2 \mathrm{E}+02$ & $7.5 \mathrm{E}+01$ \\
\hline $\mathrm{Ni}$ & $3.2 \mathrm{E}+01$ & $5.7 \mathrm{E}+01$ & $3.0 \mathrm{E}+01$ \\
\hline $\mathrm{P}$ & $<55.4$ & $<58.2$ & $6.0 \mathrm{E}+02$ \\
\hline $\mathrm{Pb}$ & $<25.6$ & $<26.9$ & $3.0 \mathrm{E}+02$ \\
\hline $\mathrm{Sb}$ & $<303$ & $<319$ & -- \\
\hline $\mathrm{Si}$ & $1.6 \mathrm{E}+02$ & $1.7 \mathrm{E}+02$ & -- \\
\hline $\mathrm{Sn}$ & $<36.1$ & $<37.9$ & -- \\
\hline $\mathrm{Sr}$ & $7.1 \mathrm{E}+00$ & $<6.41$ & -- \\
\hline $\mathrm{Ti}$ & $<6.18$ & $6.5 \mathrm{E}+00$ & -- \\
\hline $\mathrm{U}$ & $<182$ & $<191$ & $6.0 \mathrm{E}+02$ \\
\hline $\mathrm{Zn}$ & $8.2 \mathrm{E}+00$ & $2.1 \mathrm{E}+01$ & -- \\
\hline $\mathrm{Zr}$ & $8.8 \mathrm{E}+02$ & $<19.2$ & -- \\
\hline
\end{tabular}

* Dashes (--) indicate no MRQ was specified 
WSRC-TR-2003-00098, REVISION 0

SRT-RPP-2003-00026, REVISION 0

This page intentionally left blank. 


\subsection{CONCLUSION}

Six loading/elution/regeneration cycles for cesium and five loading/elution/regeneration cycles for technetium were performed to remove ${ }^{137} \mathrm{Cs}$ and ${ }^{99} \mathrm{Tc}$ (pertechnetate) from Tank 241-AW-101 waste sample with SuperLig ${ }^{\circledR} 644$ and 639 resins, respectively. Dual ion exchange columns of $1.45-\mathrm{cm}$ inside diameter were used. The columns were connected in series during loading, feed displacement, and water rinse; then were separately eluted and regenerated. The following conclusions were drawn from the tests:

1. Six cycles of loading, elution, and regeneration were performed to demonstrate ${ }^{137} \mathrm{Cs}$ could be effectively removed from a 241-AW-101 tank sample using SuperLig ${ }^{\circledR} 644$ in a small dual ion exchange column system installed in a hot cell.

- Total volume of AW-101 waste sample processed through the cesium ion exchange columns was $15 \mathrm{~L}$ or an average $180 \mathrm{BVs}$ per cycle.

- Percent ${ }^{137}$ Cs removal was $>99.99 \%$ for all six cycles.

- Cesium decontamination factor (DF) was on average $3.8 \times 10^{4}$.

- The cumulative dose $\left(1.99 \times 10^{7} \mathrm{rad}\right)$ exposed to the lead column resin was significantly below the target $1.0 \times 10^{8} \mathrm{rad}$ to have considerable impact on resin performance. At this low radiation exposure, chemical degradation may have caused most of the observed loss in resin capacity.

- A $24 \%$ reduction of resin loading capacity was observed between cycle \# 1 and cycle \#6 based on the difference of column loading at 10\% breakthrough. Based on the chemical degradation model by Battelle (WTP-RPT-046), a 14\% reduction in loading capacity was observed between cycles 5 and 10 . This suggests that the radiation effect in the $\mathrm{AW}-101$ testing contributed up to $40 \%$ of the capacity reduction. The capacity reduction was due to the synergistic effect of exposed dose to resin and chemical degradation.

- Elution of SuperLig ${ }^{\circledR} 644$ with $0.5 \underline{\mathrm{M}} \mathrm{HNO}_{3}$ was generally effective, except for cycle \#6, where strong tailing at the base was observed.

2. Five cycles of loading, elution, and regeneration were performed to demonstrate 99Tc could be effectively removed from a 241-AW-101 tank sample using SuperLig ${ }^{\circledR} 639$ resin in a small dual ion exchange system.

- SuperLig $^{\circledR} 639$ resin showed good loading performance with an average of $250 \mathrm{BVs}$ per cycle at $10 \%$ breakthrough.

- Percent ${ }^{99} \mathrm{Tc}$ (pertechnetate) removal was $>99.94 \%$ for all five cycles.

- The ${ }^{99}$ Tc DF was on average $\sim 1700$ during the five cycles. This DF was 30 times higher than previous DF observed for AW-101 testing with SuperLig ${ }^{\circledR} 639$.

- Feed displacement and elution data suggest that ${ }^{99} \mathrm{Tc}$ is removed by SuperLig® 639 resin in the form of sodium and potassium pertechnetate and the presence of potassium in the Hanford solutions could possible enhance ${ }^{99} \mathrm{Tc}$ removal.

- Technetium elution with de-ionized water at $65^{\circ} \mathrm{C}$ was effective. Less than $1 \%$ of the ${ }^{99}$ Tc remained on SuperLig ${ }^{\circledR} 639$ resin after 14 BV.

- Radiation exposure of SuperLig ${ }^{\circledR} 639$ resin is not an issue with the RPP-WTP process. 
3. Generated $12 \mathrm{~L}$ of effluent composite product for LAW vitrification.

- The average ${ }^{137} \mathrm{Cs}$ concentration of $3 \times 10^{-3} \mu \mathrm{Ci} / \mathrm{mL}$ in $12 \mathrm{~L}$ of product solution was below the maximum allowable concentration $\left(8.7 \times 10^{-2} \mu \mathrm{Ci} / \mathrm{mL}\right)$ for $\mathrm{LAW}$ vitrification. The ${ }^{99} \mathrm{Tc}$ concentration was $<3 \times 10^{-5} \mu \mathrm{Ci} / \mathrm{mL}$ to meet the concentration limit of $2.9 \times 10^{-3} \mu \mathrm{Ci} / \mathrm{mL}$ for $\mathrm{LAW}$ vitrification.

- All major constituents in the feed were accounted for in the effluent product solutions.

- Large dilutions prevented detection of most analytes in the cesium eluate product solutions.

- No major technical issues were identified.

4. All RCRA hazardous elements were below TCLP limits. 


\subsection{REFERENCES}

1. Kurath, D. E., Blanchard, D. L., Bontha, J. R., "Small Column Ion Exchange Testing of SuperLig ${ }^{\circledR} 644$ for Removal of ${ }^{137}$ Cs from Hanford Tank Waste Envelope A (Tank-241-AW-101)," PNWD-3001 (WTP-RPT-014, Rev. 0), Pacific Northwest National Laboratory, Richland, Washington, June 2000.

2. Hassan, N. M., King, W. D. and McCabe, D. J., "Small-Scale Ion Exchange Removal of Cesium and Technetium from Hanford Tank 241-AN-103," BNF-003-98-0146, Rev.1, Westinghouse Savannah River Company, August, 1999.

3. Hassan, N. M, McCabe, D. J., King, W. D. and Crowder, M. L., "Small-Scale Ion Exchange Removal of Cesium and Technetium from Hanford Tank 241-AN-102 (U),” BNF-003-98-0219, Rev. 0, Westinghouse Savannah River Company, March, 2000.

4. Fiskum, S. K., Arm, S. T., Blanchard, D. L. "Small Column Ion Exchange Testing of SuperLig ${ }^{\circledR} 644$ for removal of ${ }^{137}$ Cs from Hanford Waste Tanks 241-AZ-102 Concentrate (Envelope B)," PNWD-3267 (WTP-RPT-041, Rev. 0), Pacific Northwest National Laboratory, Richland, Washington, April 2003.

5. Kurath, D. E., Blanchard, D. L., Bontha, J. R., "Small Column Ion Exchange Testing of SuperLig ${ }^{\circledR} 644$ for Removal of ${ }^{137} \mathrm{Cs}$ from Hanford Tank Waste Envelope A (Tank-241-AN-107)," PNWD-3039 (WTP-RPT-024, Rev. 0), Pacific Northwest National Laboratory, Richland, Washington, June 2000.

6. Fiskum, S. K., Arm, S. T., Blanchard, D. L., "Small Column Ion Exchange Testing of SuperLig ${ }^{\circledR} 644$ for removal of ${ }^{137} \mathrm{Cs}$ from Hanford Waste Tanks 241-AP-101 Diluted Feed (Envelope A)," PNWD-3198 (WTP-RPT-016, Rev. 0), Pacific Northwest National Laboratory, Richland, Washington, September 2002.

7. Fiskum, S. K., Arm, S. T., Blanchard, D. L., "Small Column Ion Exchange Testing of SuperLig ${ }^{\circledR} 644$ for Removal of ${ }^{137}$ Cs from Hanford Waste Tanks 241-AN-102 (Envelope C) Mixed with Tank 241-C-104 Solids (Envelope D) Wash Permeate Solutions," PNWD-3240 (WTP-RPT-033, Rev. 0), Pacific Northwest National Laboratory, Richland, Washington, January 2003.

8. Brown, G. N., Adami, S. R., Bray, L. A, Bryan, S. A., Carlson, C. D., Carson, K. J., Deschane, J. R., Elovich, R. J., Forbes, S. J., Franz, J. A., Linehan, J. C., Shaw, W. J., Tanaka, P. K. and Telander, M. R., "Chemical and Radiological Stability of SuperLig® 644, Resorcinol-Formaldehyde and Cs-100 Cesium Ion Exchange Materials," PNL-10722, Pacific Northwest Laboratory, Richland, WA, September, 1995.

9. Oji, L. N., McCabe, D. J., "Effects of Radiation on the Physical Properties of SuperLig 644 Resin,” WSRC-TR-2000-00422 (SRT-RPP-2000-00015, Rev. 0), Westinghouse Savannah River Company, November, 2000. 


\section{WSRC-TR-2003-00098, REVISION 0 SRT-RPP-2003-00026, REVISION 0}

10. Bruening, R. L., “Chemical Stability of Ion Exchange Resins,” Task 5 Report, IBC Advanced Technologies, Inc., February 2000.

11. Arm, S. T., Blanchard, K.L., Fiskum, S.K., Weir, D.R., "Chemical Degradation of SuperLig® 644Ion Exchange Resin,” WTP-RPT-046, Rev. 0, Battelle, Pacific Northwest National Laboratory, Richland, Washington, July 2003.

12. Hassan, N. M, “Task Technical and Quality Assurance Plan for Cesium and Technetium Ion Exchange Using Tank 241-AW-101 sample (U)," WSRC-TR-200100545 (SRT-RPP-2001-00207, Rev. 1), Westinghouse Savannah River Company, March 2002.

13. Johnson, M. E., "Cesium and Technetium Ion Exchange Using Tank 241-AW-101 Test Specification,” TSP-W375-00-00030, Rev. 1, December 11, 2000.

14. Hay, M. S., Coleman, C. J., Martin, K. B., "Characterization and Dilution of a River Protection Project Sample from Tank 241-AW-101," WSRC-TR-2002-00509, Rev. 0 (SRT-RPP-2002-00255, Rev. 0), Westinghouse Savannah River Company, January 23, 2003.

15. Poirier, M. R., Burket, P. R., Siler, J. L., "Filtration of a Hanford AW-101 Waste Sample," WSRC-TR-2002-00530, Rev. 0 (SRT-RPP-2002-00263, Rev. 0), Westinghouse Savannah River Company, February 12, 2003.

16. Eibling, R.E., Nash, C.A., "Hanford Waste Simulants Created to Support the Research and Development on the River Protection Project - Waste Treatment Plant," WSRC-TR-2000-00338, SRT-RPP-2000-00017, Westinghouse Savannah River Company, March, 2001.

17. Sigg, R. A, “Technetium-99 On-Line Monitoring Studies Employing Beta Counting," BNF-98-0200, Westinghouse Savannah River Company, March, 1998.

18. S. K. Fiskum, S. T. Arm, D. L. Blanchard, Jr., “Aging Study and Small Column Ion Exchange Testing of SuperLig ${ }^{\circledR} 644$ for Removal 137Cs from Simulated AW-101 Hanford Waste," PNWD-3195 (WTP-RPT-015), Pacific Northwest National Laboratory, Richland, Washington, September 2002.

19. Hassan, N. M., McCabe, D. J., "Hanford Envelope Tank Waste Ion Exchange Distribution Coefficients (U)," SRTC-BNFL-020, Rev. 0, Westinghouse Savannah River Company, October 10, 1997.

20. MicroShield, version 5.03, Grove Engineering, 1992.

21. Kurath, D. E., Wagner, J. J., “Analysis of Spent Ion Exchange Media: SuperLig ${ }^{\circledR} 639$ and SuperLig® 644," PNWD-3037 (BNFL-RPT-028, Rev. 0), Pacific Northwest National Laboratory, Richland, Washington, May 2000.

22. Nuclear Regulatory Commission 10 CFR 61.55, Ch. 1, p. 146 (1/1/1993 Edition).

23. United States Environmental Protection Agency, "Test Methods for Evaluation Solid Waste," SW-846 Method 1311, July 1992. 


\section{APPENDIX A}

\section{AW-101 FEED CONCENTRATIONS}

Table A-1. ${ }^{137} \mathrm{Cs}[\mathrm{C}]_{0}$ in AW-101 Sample at $5 \underline{\mathrm{M}} \mathrm{Na}^{+}$

\begin{tabular}{|c|c|}
\hline LIMS \# & {$\left[{ }^{\mathbf{1 3 7}} \mathbf{C s}\right], \boldsymbol{\mu C i} / \mathbf{m L}$} \\
\hline $3-178765$ & $1.86 \mathrm{E}+02$ \\
\hline $3-178766$ & $1.83 \mathrm{E}+02$ \\
\hline $3-180091$ & $1.64 \mathrm{E}+02$ \\
\hline $3-180092$ & $1.70 \mathrm{E}+02$ \\
\hline $3-183211$ & $1.63 \mathrm{E}+02$ \\
\hline $3-183212$ & $1.63 \mathrm{E}+02$ \\
\hline $3-185766$ & $1.76 \mathrm{E}+02$ \\
\hline $3-185767$ & $1.75 \mathrm{E}+02$ \\
\hline $3-186524$ & $1.72 \mathrm{E}+02$ \\
\hline $3-186525$ & $1.83 \mathrm{E}+02$ \\
\hline $3-186681$ & $1.71 \mathrm{E}+02$ \\
\hline $3-186682$ & $1.74 \mathrm{E}+02$ \\
\hline $3-187416$ & $1.72 \mathrm{E}+02$ \\
\hline $3-187417$ & $1.99 \mathrm{E}+02$ \\
\hline Average & $\mathbf{1 . 7 5 E}+\mathbf{0 2}$ \\
\hline RSD & $\mathbf{5 . 4 9 E - 0 2}$ \\
\hline
\end{tabular}

Table A-2. ${ }^{99} \mathrm{Tc}[\mathrm{C}]_{\mathrm{o}}$ in AW-101 wastes Sample (filtrate at $5 \underline{\mathrm{M} \mathrm{Na}}{ }^{+}$)

\begin{tabular}{|c|c|c|c|}
\hline \multicolumn{4}{|c|}{ PERTECHNETATE } \\
\hline LIMS \# & {$[$ Tc-99], $\mathbf{d p m} / \mathbf{m L}$} & {$[$ Tc-99], $\boldsymbol{\mu C i} / \mathbf{m L}$} & {$[$ Tc-99], $\mathbf{~ m g} / \mathbf{L}$} \\
\hline $3-186357$ & $1.45 \mathrm{E}+05$ & $6.53 \mathrm{E}-02$ & 3840 \\
\hline $3-186358$ & $1.40 \mathrm{E}+05$ & $6.31 \mathrm{E}-02$ & 3720 \\
\hline $3-186780$ & $1.56 \mathrm{E}+05$ & $7.03 \mathrm{E}-02$ & 4140 \\
\hline $3-186781$ & $1.47 \mathrm{E}+05$ & $6.62 \mathrm{E}-02$ & 3890 \\
\hline Average & $\mathbf{1 . 4 7 E}+\mathbf{0 5}$ & $\mathbf{6 . 6 2 E - 0 2}$ & $\mathbf{3 . 9 0 E}+\mathbf{0 3}$ \\
\hline RSD & $\mathbf{4 . 5 5 E - 0 2}$ & $\mathbf{4 . 5 5 E - 0 2}$ & $\mathbf{4 . 5 3 E - 0 2}$ \\
\hline
\end{tabular}


This page intentionally left blank. 


\section{APPENDIX B - BATCH CONTACT DATA}

APPENDIX B-1: CESIUM BATCH DATA

Envelope A (Tank 241-AW-101 actual \& stimulant)

Resin: SuperLig ${ }^{\circledR} 644$

Batch \#: 1-D5-03-06-02-35-60

Table B-1-1. $K_{d}$ Values for ${ }^{137}$ Cs from AW-101 Actual Waste Sample

\begin{tabular}{|c|c|c|c|c|c|c|c|c|c|c|c|c|c|}
\hline \multicolumn{3}{|c|}{$\begin{array}{l}{ }^{137} \text { Cs-Kd values } \mathrm{K}^{+}(\mathrm{M}) \\
\text { Hanford: Envelope A }(\mathrm{AW}-10.43\end{array}$} & \multirow[b]{2}{*}{$\begin{array}{c}\text { Resin } \\
\text { Mass (g) }\end{array}$} & \multirow[b]{2}{*}{$\begin{array}{l}\text { Solution } \\
\text { Vol. (mL) }\end{array}$} & \multirow[b]{2}{*}{$\begin{array}{l}\text { Phase } \\
\text { Ratio }\end{array}$} & \multirow[b]{2}{*}{ F-factor } & \multirow[b]{2}{*}{$\begin{array}{l}\text { Cs-137* } \\
(\mu \mathrm{Ci} / \mathrm{mL})\end{array}$} & \multirow[b]{2}{*}{$\begin{array}{c}\text { Cs-137* } \\
\text { (M) }\end{array}$} & \multirow[b]{2}{*}{$\begin{array}{l}\text { Dilution } \\
\text { Factor }\end{array}$} & \multicolumn{2}{|c|}{$\begin{array}{l}\text { Concentration Used } \\
\text { in Kd Tests }\end{array}$} & \multirow[b]{2}{*}{$\begin{array}{c}\mathrm{K}_{\mathrm{d}} \\
(\mathrm{mL} / \mathrm{g})\end{array}$} & \multirow[b]{2}{*}{$\begin{array}{l}\text { Avg, } K_{d} \\
(\mathrm{~mL} / \mathrm{g})\end{array}$} \\
\hline Sample ID & LIMS \# & $\begin{array}{l}\text { Solution } \\
\text { Mass }(\mathrm{g}) \\
\end{array}$ & & & & & & & & $\begin{array}{l}\text { Cs-137* } \\
(\mu \mathrm{Ci} / \mathrm{mL})\end{array}$ & $\begin{array}{l}\text { Cs-137* } \\
(\mathrm{M})\end{array}$ & & \\
\hline NH44-AW101-Kd-1 & $3-180087$ & 12.629 & 0.1002 & 9.92 & 99 & 0.60 & 1.72 & $1.45 \mathrm{E}-07$ & 11.7 & 20.2 & $1.70 \mathrm{E}-06$ & 1201 & na \\
\hline NH44-AW101-Kd-1D & $3-180088$ & 12.559 & 0.1002 & 9.87 & 98 & 0.60 & 1.61 & $1.36 \mathrm{E}-07$ & 10.9 & 17.6 & $1.48 \mathrm{E}-06$ & 1392 & 1297 \\
\hline NH44-AW101-Kd-2 & 3-180089 & 12.4 & 1.0024 & 9.74 & 9.7 & 0.60 & $9.54 \mathrm{E}-02$ & 8.05E-09 & 11.1 & 1.1 & $8.90 \mathrm{E}-08$ & 2546 & na \\
\hline NH44-AW101-Kd-2D & $3-180090$ & 12.094 & 1.0023 & 9.50 & 9.5 & 0.60 & $8.89 \mathrm{E}-02$ & 7.50E-09 & 11.0 & 1.0 & $8.26 \mathrm{E}-08$ & 2678 & 2612 \\
\hline AW101-LCS-02513-1 & $3-180091$ & 12.295 & na & 9.66 & na & na & 15.01 & $1.27 \mathrm{E}-06$ & 10.9 & 163.7 & $1.38 \mathrm{E}-05$ & na & na \\
\hline AW101-LCS-02513-1D & $3-180092$ & 12.188 & na & 9.57 & na & na & 15.52 & $1.31 \mathrm{E}-06$ & 11.0 & 170.0 & $1.43 \mathrm{E}-05$ & na & na \\
\hline
\end{tabular}

* dilution corrected

na - not applicable

\section{Table B-1-2. $K_{d}$ Values for ${ }^{137}$ Cs from AW-101 Simulant}

\begin{tabular}{|c|c|c|c|c|c|c|c|c|c|c|}
\hline \multicolumn{3}{|c|}{$\begin{array}{l}{ }^{137} \text { Cs-Kd values } \\
\text { Hanford: Envelope } \mathrm{A}(\mathrm{AW}-101)\end{array}$} & & & & & & & & \\
\hline Sample ID & LIMS \# & $\begin{array}{l}\text { Solution } \\
\text { Mass (g) }\end{array}$ & $\begin{array}{c}\text { Resin Mass } \\
\text { (g) }\end{array}$ & $\begin{array}{l}\text { Solution } \\
\text { Vol. (mL) }\end{array}$ & $\begin{array}{l}\text { Phase } \\
\text { Ratio }\end{array}$ & F-factor & $\begin{array}{c}\text { Cs (total) } \\
(\mu \mathrm{g} / \mathrm{L})\end{array}$ & $\begin{array}{c}\text { Blank Avg. } \\
(\mu \mathrm{g} / \mathrm{L})\end{array}$ & $\underset{(\mathrm{mL} / \mathrm{g})}{\mathrm{K}_{\mathrm{d}}}$ & $\begin{array}{c}\operatorname{Avg}, K_{d} \\
(\mathrm{~mL} / \mathrm{g})\end{array}$ \\
\hline NH44-AW101Sim-Kd-1 & $3-180691$ & 12.5587 & 0.1006 & 9.87 & 98 & 0.60 & 896 & na & 1572 & na \\
\hline NH44-AW101Sim-Kd-1D & $3-180692$ & 12.5476 & 0.1003 & 9.86 & 98 & 0.60 & 932 & na & 1508 & 1540 \\
\hline AW101-LCS-02605-1 & $3-180693$ & 12.6377 & na & 9.93 & na & na & 9450 & na & na & na \\
\hline AW101-LCS-02605-1D & $3-180694$ & 12.5103 & na & 9.83 & na & na & 9580 & 9515 & na & na \\
\hline
\end{tabular}

na $=$ not applicable 
APPENDIX B-2: CESIUM BATCH DATA

Envelope A (Tank 241-AW-101 actual)

Resin: SuperLig ${ }^{\circledR} 639$

Batch \#: 1-R2-03-27-02-20-45

Table B-2-1: $K_{d}$ values for ${ }^{99}$ Tc from AW-101 Actual Waste Sample

\begin{tabular}{|c|c|c|c|c|c|c|c|c|c|c|c|}
\hline \multicolumn{12}{|c|}{ 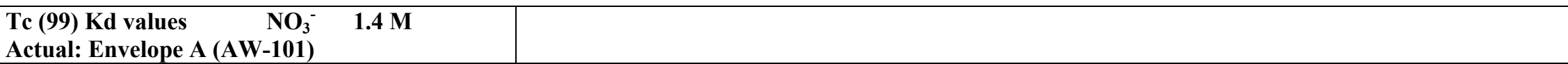 } \\
\hline Sample ID & LIMS \# & $\begin{array}{l}\text { Solution } \\
\text { Mass (g) }\end{array}$ & $\begin{array}{c}\text { Resin } \\
\operatorname{Mass}(g)\end{array}$ & $\begin{array}{c}\text { Solution } \\
\text { Vol. }(\mathbf{m L})\end{array}$ & $\begin{array}{l}\text { Phase } \\
\text { Ratio }\end{array}$ & F-factor & $\begin{array}{c}\mathrm{Tc99} \\
(\mu \mathrm{g} / \mathrm{L})\end{array}$ & $\begin{array}{l}\text { Dilution } \\
\text { Factor }\end{array}$ & $\begin{array}{c}\text { Tc-99 dl } \\
\text { Corrected }\end{array}$ & $\underset{(\mathrm{mL} / \mathrm{g})}{\mathrm{K}_{\mathrm{d}}^{1}}$ & $\begin{array}{l}\text { Avg. } K_{d}^{1} \\
(\mathrm{~mL} / \mathrm{g})\end{array}$ \\
\hline AW101-Kd39-1-filtrate-1 & $3-180695$ & 12.161 & 0.1 & 9.55 & 96 & 0.98 & 43 & 11.4 & 492 & 839 & na \\
\hline AW101-Kd39-1-filtrate-2 & $3-180696$ & 11.74 & 0.102 & 9.22 & 90 & 0.98 & 44 & 11.5 & 508 & 766 & 802 \\
\hline AW101-Kd39-2-filtrate-1 & $3-180697$ & 12.121 & 1.000 & 9.52 & 10 & 0.98 & 16 & 11.9 & 190 & 231 & na \\
\hline AW101-Kd39-2-filtrate-2 & $3-180698$ & 12.157 & 1.000 & 9.55 & 10 & 0.98 & 16 & 11.3 & 181 & 245 & 238 \\
\hline NH39-CTR-02607-1 & $3-178765$ & $\mathrm{~nm}$ & na & na & na & na & 308 & 15.9 & 4900 & na & na \\
\hline NH39-CTR-02607-1D & $3-178766$ & $\mathrm{~nm}$ & na & na & na & na & 290 & 15.7 & 4550 & na & na \\
\hline
\end{tabular}

$\mathrm{nm}=$ not measured

na $=$ not applicable 


\section{APPENDIX C - CESIUM LOADING AND ELUTION DATA}

\section{APPENDIX C1-1: LOADING CYCLE \#1}

\section{Lead Column}

Resin: SuperLig ${ }^{\circledR} 644$

Resin batch \# I-D5-03-06-02-35-60

Column size $=1.45 \mathrm{~cm} ; \mathrm{L} / \mathrm{D}=6.2$

Flow rate $=0.69 \mathrm{BV} / \mathrm{h}(0.17 \mathrm{~mL} / \mathrm{min}) ; \mathrm{BV}=15 \mathrm{~mL}$

Temperature $=25 \pm 1^{\circ} \mathrm{C}$

\begin{tabular}{|c|c|c|c|c|c|}
\hline LIMS \# & $\mathbf{B V}$ & {$[\mathbf{1 3 7 C s}], \boldsymbol{\mu C i} / \mathbf{m L}$} & {$[\mathbf{1 3 7 C s}], \mathbf{C} / \mathbf{C o}$} & {$\left[\mathbf{K}^{+}\right], \mathbf{M}$} & {$\left[\mathbf{N a}^{+}\right], \mathbf{M}$} \\
\hline $3-183188$ & 9.8 & $1.14 \mathrm{E}-02$ & $6.51 \mathrm{E}-05$ & 0.47 & 5.52 \\
\hline $3-183189$ & 19.7 & $8.24 \mathrm{E}-03$ & $4.71 \mathrm{E}-05$ & $\mathrm{~nm}$ & $\mathrm{~nm}$ \\
\hline $3-183190$ & 29.8 & $7.37 \mathrm{E}-03$ & $4.21 \mathrm{E}-05$ & $\mathrm{~nm}$ & $\mathrm{~nm}$ \\
\hline $3-183191$ & 39.6 & $8.60 \mathrm{E}-03$ & $4.91 \mathrm{E}-05$ & $\mathrm{~nm}$ & $\mathrm{~nm}$ \\
\hline $3-183192$ & 48.9 & $7.34 \mathrm{E}-03$ & $4.19 \mathrm{E}-05$ & 0.48 & 5.83 \\
\hline $3-183193$ & 57.8 & $6.69 \mathrm{E}-03$ & $3.82 \mathrm{E}-05$ & $\mathrm{~nm}$ & $\mathrm{~nm}$ \\
\hline $3-183194$ & 66.9 & $9.87 \mathrm{E}-03$ & $5.64 \mathrm{E}-05$ & $\mathrm{~nm}$ & $\mathrm{~nm}$ \\
\hline $3-183195$ & 76.2 & $2.09 \mathrm{E}-03$ & $1.19 \mathrm{E}-05$ & $\mathrm{~nm}$ & $\mathrm{~nm}$ \\
\hline $3-183196$ & 86.0 & $1.38 \mathrm{E}-03$ & $7.88 \mathrm{E}-06$ & $\mathrm{~nm}$ & $\mathrm{~nm}$ \\
\hline $3-183197$ & 96.2 & $8.22 \mathrm{E}-03$ & $4.70 \mathrm{E}-05$ & 0.47 & 4.18 \\
\hline $3-183198$ & 106.4 & $2.37 \mathrm{E}-03$ & $1.35 \mathrm{E}-05$ & $\mathrm{~nm}$ & $\mathrm{~nm}$ \\
\hline $3-183199$ & 116.6 & $1.34 \mathrm{E}-03$ & $7.65 \mathrm{E}-06$ & $\mathrm{~nm}$ & $\mathrm{~nm}$ \\
\hline $3-183200$ & 126.9 & $2.12 \mathrm{E}-03$ & $1.21 \mathrm{E}-05$ & $\mathrm{~nm}$ & $\mathrm{~nm}$ \\
\hline $3-183201$ & 137.0 & $2.16 \mathrm{E}-03$ & $1.23 \mathrm{E}-05$ & $\mathrm{~nm}$ & $\mathrm{~nm}$ \\
\hline $3-183202$ & 147.2 & $3.59 \mathrm{E}-03$ & $2.05 \mathrm{E}-05$ & 0.51 & 4.74 \\
\hline $3-183532$ & 157.3 & $1.41 \mathrm{E}-03$ & $8.05 \mathrm{E}-06$ & $\mathrm{~nm}$ & $\mathrm{~nm}$ \\
\hline $3-183533$ & 167.5 & $7.48 \mathrm{E}-02$ & $4.27 \mathrm{E}-04$ & $\mathrm{~nm}$ & $\mathrm{~nm}$ \\
\hline $3-183534$ & 180.1 & $4.35 \mathrm{E}-01$ & $2.48 \mathrm{E}-03$ & 0.52 & 4.74 \\
\hline $3-183535$ & 194.3 & $1.29 \mathrm{E}+01$ & $7.37 \mathrm{E}-02$ & 0.54 & 4.87 \\
\hline 137 & & & & \\
\hline
\end{tabular}

$\left[{ }^{137} \mathrm{Cs}\right]_{\mathbf{o}}=175 \mu \mathrm{Ci} / \mathbf{m L}$

$\mathrm{nm}=$ not measured 
APPENDIX C1-2: LOADING CYCLE \#1

Lag Column

Resin: SuperLig ${ }^{\circledR} 644$

Resin batch \# I-D5-03-06-02-35-60

Column size $=1.45 \mathrm{~cm}$

Flow rate $=0.69 \mathrm{BV} / \mathrm{h}(0.17 \mathrm{~mL} / \mathrm{min}) ; \mathrm{BV}=15 \mathrm{~mL}$

Individual Samples - Lag Column

\begin{tabular}{|c|c|c|c|c|}
\hline LIMS \# & \# BV Effluent & $\left.{ }^{[\mathbf{1 3 7}} \mathbf{C s}\right], \boldsymbol{\mu} \mathbf{C i} / \mathbf{m L}$ & $\left.{ }^{[\mathbf{1 3 7}} \mathbf{C s}\right], \mathbf{C} / \mathbf{C o}$ & {$\left[\mathbf{K}^{+}\right], \mathbf{M}^{*}$} \\
\hline $3-183203$ & 19.7 & $6.45 \mathrm{E}-05$ & $3.68 \mathrm{E}-07$ & 0.450128 \\
\hline $3-183204$ & 39.6 & $6.55 \mathrm{E}-05$ & $3.74 \mathrm{E}-07$ & 0.460358 \\
\hline $3-183205$ & 57.8 & $3.71 \mathrm{E}-04$ & $2.12 \mathrm{E}-06$ & 0.465473 \\
\hline $3-183206$ & 76.2 & $3.86 \mathrm{E}-04$ & $2.20 \mathrm{E}-06$ & 0.491049 \\
\hline $3-183207$ & 96.2 & $1.19 \mathrm{E}-04$ & $6.80 \mathrm{E}-07$ & 0.480818 \\
\hline $3-183208$ & 116.6 & $1.53 \mathrm{E}-04$ & $8.74 \mathrm{E}-07$ & 0.411765 \\
\hline $3-183209$ & 137.0 & $2.39 \mathrm{E}-04$ & $1.37 \mathrm{E}-06$ & 0.409207 \\
\hline $3-183210$ & 157.3 & $1.60 \mathrm{E}-04$ & $9.14 \mathrm{E}-07$ & 0.332481 \\
\hline $3-183543$ & 180.1 & $7.52 \mathrm{E}-04$ & $4.30 \mathrm{E}-06$ & $\mathrm{~nm}$ \\
\hline
\end{tabular}

Composite Fractions - Lag Column

\begin{tabular}{|c|c|c|c|}
\hline LIMS \# & Effluent fraction \# & {$\left[{ }^{\mathbf{1 3 7}} \mathbf{C s}\right], \mu \mathbf{C i} / \mathbf{m L}$} & {$\left[{ }^{\mathbf{1 3 7}} \mathbf{C s}\right], \mathbf{C} / \mathbf{C o}$} \\
\hline $3-183215$ & bottle \# 1 - 20 BV & $1.48 \mathrm{E}-04$ & $8.45 \mathrm{E}-07$ \\
\hline $3-183216$ & bottle \# $-\sim 20 \mathrm{BV}$ & $1.28 \mathrm{E}-04$ & $7.31 \mathrm{E}-07$ \\
\hline $3-183217$ & bottle \# 3 - 20 BV & $1.63 \mathrm{E}-04$ & $9.31 \mathrm{E}-07$ \\
\hline $3-183218$ & bottle \# 4 - 20 BV & $2.17 \mathrm{E}-04$ & $1.24 \mathrm{E}-06$ \\
\hline $3-183219$ & bottle \# 5 - 20 BV & $2.05 \mathrm{E}-04$ & $1.17 \mathrm{E}-06$ \\
\hline $3-183220$ & bottle \# 6 - 20 BV & $1.23 \mathrm{E}-04$ & $7.03 \mathrm{E}-07$ \\
\hline $3-183221$ & bottle \# 7 - 20 BV & $2.22 \mathrm{E}-04$ & $1.27 \mathrm{E}-06$ \\
\hline $3-183222$ & bottle \# $8-\sim 20 \mathrm{BV}$ & $5.85 \mathrm{E}-04$ & $3.34 \mathrm{E}-06$ \\
\hline $3-183547$ & bottle \# 9 - 20 BV & $4.74 \mathrm{E}-04$ & $2.70 \mathrm{E}-06$ \\
\hline $3-183548$ & bottle \# 10 - 10 BV & $1.24 \mathrm{E}-03$ & $7.08 \mathrm{E}-06$ \\
\hline
\end{tabular}

* by atomic absorption (AA)

$\mathrm{nm}=$ not measured 
APPENDIX C1-3: ELUTION CYCLE \#1

Lead Column

Eluant $=0.5 \mathrm{M} \mathrm{HNO}$

Flow rate $=0.63 \mathrm{BV} / \mathrm{h}(0.11 \mathrm{~mL} / \mathrm{min}) ; \mathrm{BV}-10.9 \mathrm{~mL}$

Resin batch \# I-D5-03-06-02-35-60

Column size $=1.45 \mathrm{~cm}$

Elution samples; BV -elution based

\begin{tabular}{|r|c|c|c|c|r|}
\hline LIMS \# & $\mathbf{B V}$ & $\begin{array}{c}\left.{ }^{\mathbf{1 3 7}} \mathbf{C s}\right], \\
\boldsymbol{\mu} \mathbf{C i} / \mathbf{m L}\end{array}$ & $\left.{ }^{137} \mathbf{C s}\right], \mathbf{C} / \mathbf{C o}$ & {$\left[\mathbf{K}^{+}\right], \mathbf{M}$} & \multicolumn{1}{|c|}{$\left[\mathbf{N a}{ }^{+}, \mathbf{M}\right.$} \\
\hline $3-183693$ & 0.63 & $9.73 \mathrm{E}-02$ & $5.56 \mathrm{E}-04$ & $9.21 \mathrm{E}-03$ & $1.19 \mathrm{E}-01$ \\
\hline $3-183694$ & 1.26 & $8.60 \mathrm{E}-01$ & $4.91 \mathrm{E}-03$ & $4.77 \mathrm{E}-02$ & $3.53 \mathrm{E}-01$ \\
\hline $3-183695$ & 1.89 & $8.08 \mathrm{E}+03$ & $4.62 \mathrm{E}+01$ & $8.26 \mathrm{E}-02$ & $7.02 \mathrm{E}-01$ \\
\hline $3-183696$ & 2.52 & $2.43 \mathrm{E}+03$ & $1.39 \mathrm{E}+01$ & $2.27 \mathrm{E}-02$ & $2.72 \mathrm{E}-01$ \\
\hline $3-183697$ & 3.15 & $2.07 \mathrm{E}+02$ & $1.18 \mathrm{E}+00$ & $1.27 \mathrm{E}-02$ & $1.49 \mathrm{E}-01$ \\
\hline $3-183698$ & 4.41 & $3.54 \mathrm{E}+01$ & $2.02 \mathrm{E}-01$ & $5.53 \mathrm{E}-03$ & $8.56 \mathrm{E}-02$ \\
\hline $3-183699$ & 5.67 & $8.68 \mathrm{E}+00$ & $4.96 \mathrm{E}-02$ & $1.68 \mathrm{E}-02$ & $1.72 \mathrm{E}-01$ \\
\hline $3-183700$ & 6.93 & $2.90 \mathrm{E}+00$ & $1.66 \mathrm{E}-02$ & $1.91 \mathrm{E}-02$ & $2.21 \mathrm{E}-01$ \\
\hline $3-183701$ & 8.19 & $2.04 \mathrm{E}+00$ & $1.16 \mathrm{E}-02$ & $1.28 \mathrm{E}-02$ & $1.45 \mathrm{E}-01$ \\
\hline $3-183702$ & 9.45 & $1.14 \mathrm{E}+00$ & $6.53 \mathrm{E}-03$ & $6.59 \mathrm{E}-03$ & $8.46 \mathrm{E}-02$ \\
\hline
\end{tabular}

\section{Dilution Factors}

\begin{tabular}{|l|c|c|c|c|c|c|c|}
\hline Eluate Sample ID & LIMS \# & $\begin{array}{c}\text { Water, } \\
\mathbf{m L}\end{array}$ & $\begin{array}{c}\text { Sample, } \\
\mathbf{m L}\end{array}$ & $\begin{array}{l}\text { Dilution } \\
\text { Factor }\end{array}$ & $\begin{array}{c}{ }^{\left[{ }^{137} \mathbf{C s}\right],} \\
\boldsymbol{\mu C i} / \mathbf{m L}\end{array}$ & $\begin{array}{c}{\left[\mathbf{K}^{+}\right],} \\
\mathbf{m g} / \mathbf{L}\end{array}$ & $\begin{array}{c}{\left[\mathbf{N a}{ }^{+}\right],} \\
\mathbf{m g} / \mathbf{L}\end{array}$ \\
\hline NH-W101-CR1-LEE-1 & $3-183693$ & 24.5532 & 0.098825832 & 249 & $3.90 \mathrm{E}-04$ & 1.44 & 11 \\
\hline NH-W101-CR1-LEE-2 & $3-183694$ & 24.8675 & 0.100782779 & 248 & $3.47 \mathrm{E}-03$ & 7.51 & 32.8 \\
\hline NH-W101-CR1-LEE-3 & $3-183695$ & 24.877 & 0.096868885 & 258 & $3.14 \mathrm{E}+01$ & 12.5 & 62.6 \\
\hline NH-W101-CR1-LEE-4 & $3-183696$ & 24.9181 & 0.096868885 & 258 & $9.41 \mathrm{E}+00$ & 3.43 & 24.2 \\
\hline NH-W101-CR1-LEE-5 & $3-183697$ & 24.8395 & 0.098825832 & 252 & $8.22 \mathrm{E}-01$ & 1.96 & 13.6 \\
\hline NH-W101-CR1-LEE-7 & $3-183698$ & 5.0021 & 0.096868885 & 53 & $6.72 \mathrm{E}-01$ & 4.1 & 37.4 \\
\hline NH-W101-CR1-LEE-9 & $3-183699$ & 4.983 & 0.100782779 & 50 & $1.72 \mathrm{E}-01$ & 13 & 78.6 \\
\hline NH-W101-CR1-LEE-11 & $3-183700$ & 4.9803 & 0.098825832 & 51 & $5.64 \mathrm{E}-02$ & 14.5 & 99 \\
\hline NH-W101-CR1-LEE-13 & $3-183701$ & 4.9894 & 0.076320939 & 66 & $3.07 \mathrm{E}-02$ & 7.52 & 50.2 \\
\hline NH-W101-CR1-LEE-15 & $3-183702$ & 4.9816 & 0.090998043 & 56 & $2.05 \mathrm{E}-02$ & 4.61 & 34.9 \\
\hline
\end{tabular}


APPENDIX C2-1: LOADING CYCLE \#2

Lead Column

Resin: SuperLig ${ }^{\circledR} 644$

Resin batch \# I-D5-03-06-02-35-60

Column size $=1.45 \mathrm{~cm} ; \mathrm{L} / \mathrm{D}=6.2$

Flow rate $=0.58 \mathrm{BV} / \mathrm{h}(0.15 \mathrm{~mL} / \mathrm{min}) ; \mathrm{BV}=15 \mathrm{~mL}$

\begin{tabular}{|c|c|c|c|c|c|}
\hline LIMS \# & $\mathbf{B V}$ & $\left.{ }^{[\mathbf{1 3 7}} \mathbf{C s}\right], \boldsymbol{\mu C \mathbf { C } / \mathbf { m L }}$ & $\left.{ }^{[\mathbf{1 3 7}} \mathbf{C s}\right], \mathbf{C} / \mathbf{C o}$ & {$\left[\mathbf{K}^{+}\right], \mathbf{M}$} & {$\left[\mathbf{N a}^{+}\right], \mathbf{M}$} \\
\hline $3-184237$ & 3.8 & $1.54 \mathrm{E}-01$ & $8.82 \mathrm{E}-04$ & $\mathrm{~nm}$ & $\mathrm{~nm}$ \\
\hline $3-184238$ & 7.6 & $3.97 \mathrm{E}-02$ & $2.27 \mathrm{E}-04$ & 0.51 & 5.61 \\
\hline $3-184239$ & 15.6 & $9.80 \mathrm{E}-02$ & $5.60 \mathrm{E}-04$ & $\mathrm{~nm}$ & $\mathrm{~nm}$ \\
\hline $3-184243$ & 53.9 & $9.57 \mathrm{E}-01$ & $5.47 \mathrm{E}-03$ & $\mathrm{~nm}$ & $\mathrm{~nm}$ \\
\hline $3-184244$ & 63.9 & $3.29 \mathrm{E}-01$ & $1.88 \mathrm{E}-03$ & $\mathrm{~nm}$ & $\mathrm{~nm}$ \\
\hline $3-184245$ & 74.0 & $7.98 \mathrm{E}-01$ & $4.56 \mathrm{E}-03$ & $\mathrm{~nm}$ & $\mathrm{~nm}$ \\
\hline $3-184246$ & 83.9 & $1.20 \mathrm{E}-01$ & $6.85 \mathrm{E}-04$ & $\mathrm{~nm}$ & $\mathrm{~nm}$ \\
\hline $3-184247$ & 93.9 & $2.16 \mathrm{E}-01$ & $1.24 \mathrm{E}-03$ & 0.48 & 5.39 \\
\hline $3-184248$ & 103.9 & $2.20 \mathrm{E}-02$ & $1.26 \mathrm{E}-04$ & $\mathrm{~nm}$ & $\mathrm{~nm}$ \\
\hline $3-184249$ & 113.9 & $3.00 \mathrm{E}-02$ & $1.72 \mathrm{E}-04$ & $\mathrm{~nm}$ & $\mathrm{~nm}$ \\
\hline $3-184252$ & 140.7 & $4.56 \mathrm{E}-01$ & $2.61 \mathrm{E}-03$ & 0.56 & 4.74 \\
\hline $3-184253$ & 148.4 & $4.15 \mathrm{E}-01$ & $2.37 \mathrm{E}-03$ & $\mathrm{~nm}$ & $\mathrm{~nm}$ \\
\hline $3-184254$ & 156.0 & $2.49 \mathrm{E}-01$ & $1.42 \mathrm{E}-03$ & $\mathrm{~nm}$ & $\mathrm{~nm}$ \\
\hline $3-184255$ & 163.4 & $7.31 \mathrm{E}-01$ & $4.18 \mathrm{E}-03$ & $\mathrm{~nm}$ & $\mathrm{~nm}$ \\
\hline $3-184256$ & 170.7 & $2.02 \mathrm{E}+00$ & $1.16 \mathrm{E}-02$ & $\mathrm{~nm}$ & $\mathrm{~nm}$ \\
\hline $3-184257$ & 177.8 & $1.27 \mathrm{E}+01$ & $7.25 \mathrm{E}-02$ & 0.52 & 4.61 \\
\hline $3-184258$ & 184.7 & $1.67 \mathrm{E}+01$ & $9.54 \mathrm{E}-02$ & $\mathrm{~nm}$ & $\mathrm{~nm}$ \\
\hline $3-184259$ & 191.8 & $3.34 \mathrm{E}+01$ & $1.91 \mathrm{E}-01$ & $\mathrm{~nm}$ & $\mathrm{~nm}$ \\
\hline $3-184260$ & 199.4 & $5.64 \mathrm{E}+01$ & $3.22 \mathrm{E}-01$ & $\mathrm{~nm}$ & $\mathrm{~nm}$ \\
\hline $3-184261$ & 207.6 & $8.10 \mathrm{E}+01$ & $4.63 \mathrm{E}-01$ & $\mathrm{~nm}$ & $\mathrm{~nm}$ \\
\hline $3-184262$ & 216.2 & $1.32 \mathrm{E}+02$ & $7.55 \mathrm{E}-01$ & $\mathbf{n m}$ & $\mathbf{4 . 4 6}$ \\
\hline
\end{tabular}

$\mathrm{nm}-$ not measured 
APPENDIX C2-2: LOADING CYCLE \#2

Lag Column

Resin: SuperLig ${ }^{\circledR} 644$

Resin batch \# I-D5-03-06-02-35-60

Column size $=1.45 \mathrm{~cm}$

Flow rate $=0.58 \mathrm{BV} / \mathrm{h}(0.15 \mathrm{~mL} / \mathrm{min}) ; \mathrm{BV}=15 \mathrm{~mL}$

Individual Samples - Lag Column

\begin{tabular}{|c|c|c|c|c|}
\hline LIMS \# & \# BV Effluent & $\left.{ }^{\mathbf{1 3 7}} \mathbf{C s}\right], \boldsymbol{\mu C i} / \mathbf{m L}$ & {$\left[{ }^{\mathbf{1 3 7}} \mathbf{C s}\right], \mathbf{C} / \mathbf{C o}$} & {$\left[\mathbf{K}^{+}\right], \mathbf{M}^{*}$} \\
\hline $3-184263$ & 15.6 & $7.65 \mathrm{E}-04$ & $4.37 \mathrm{E}-06$ & 0.41 \\
\hline $3-184264$ & 34.2 & $5.60 \mathrm{E}-04$ & $3.20 \mathrm{E}-06$ & $\mathrm{~nm}$ \\
\hline $3-184265$ & 53.9 & $5.19 \mathrm{E}-04$ & $2.97 \mathrm{E}-06$ & $\mathrm{~nm}$ \\
\hline $3-184266$ & 74.0 & $4.35 \mathrm{E}-04$ & $2.49 \mathrm{E}-06$ & $\mathrm{~nm}$ \\
\hline $3-184267$ & 93.9 & $8.54 \mathrm{E}-04$ & $4.88 \mathrm{E}-06$ & 0.43 \\
\hline $3-184268$ & 113.9 & $5.00 \mathrm{E}-04$ & $2.86 \mathrm{E}-06$ & $\mathrm{~nm}$ \\
\hline $3-184269$ & 132.4 & $8.95 \mathrm{E}-04$ & $5.11 \mathrm{E}-06$ & $\mathrm{~nm}$ \\
\hline $3-184270$ & 148.4 & $4.09 \mathrm{E}-04$ & $2.34 \mathrm{E}-06$ & $\mathrm{~nm}$ \\
\hline $3-184271$ & 163.4 & $5.78 \mathrm{E}-04$ & $3.30 \mathrm{E}-06$ & $\mathrm{~nm}$ \\
\hline $3-184272$ & 177.8 & $1.75 \mathrm{E}-04$ & $9.98 \mathrm{E}-07$ & 0.43 \\
\hline $3-184273$ & 191.8 & $1.28 \mathrm{E}-03$ & $7.31 \mathrm{E}-06$ & $\mathrm{~nm}$ \\
\hline $3-184274$ & 207.6 & $1.88 \mathrm{E}-03$ & $1.07 \mathrm{E}-05$ & $\mathrm{~nm}$ \\
\hline
\end{tabular}

$\mathrm{nm}=$ not measured

Composite Fractions - Lag Column

\begin{tabular}{|c|c|c|c|}
\hline LIMS \# & Effluent fraction \# & {$\left[{ }^{\mathbf{1 3 7}} \mathbf{C s}\right], \boldsymbol{\mu C i} / \mathbf{m L}$} & {$\left[{ }^{\mathbf{1 3 7}} \mathbf{C s}\right], \mathbf{C} / \mathbf{C o}$} \\
\hline $3-184275$ & bottle \# $1-\sim 20 \mathrm{BV}$ & $5.70 \mathrm{E}-03$ & $3.26 \mathrm{E}-05$ \\
\hline $3-184276$ & bottle \# $2-\sim 20 \mathrm{BV}$ & $8.35 \mathrm{E}-04$ & $4.77 \mathrm{E}-06$ \\
\hline $3-184277$ & bottle \# $3-\sim 20 \mathrm{BV}$ & $8.55 \mathrm{E}-04$ & $4.89 \mathrm{E}-06$ \\
\hline $3-184278$ & bottle \# 4 - 20 BV & $5.47 \mathrm{E}-04$ & $3.12 \mathrm{E}-06$ \\
\hline $3-184279$ & bottle \# 5 $\sim 20 \mathrm{BV}$ & $6.62 \mathrm{E}-04$ & $3.78 \mathrm{E}-06$ \\
\hline $3-184280$ & bottle \# $-\sim 20 \mathrm{BV}$ & $5.91 \mathrm{E}-04$ & $3.38 \mathrm{E}-06$ \\
\hline $3-184281$ & bottle \# 7 - 20 BV & $6.77 \mathrm{E}-04$ & $3.87 \mathrm{E}-06$ \\
\hline $3-184282$ & bottle \# $8-\sim 20 \mathrm{BV}$ & $8.25 \mathrm{E}-04$ & $4.71 \mathrm{E}-06$ \\
\hline $3-184283$ & bottle \# $9-\sim 20 \mathrm{BV}$ & $8.26 \mathrm{E}-04$ & $4.72 \mathrm{E}-06$ \\
\hline $3-184284$ & bottle \# 10 - 20 BV & $4.74 \mathrm{E}-04$ & $2.71 \mathrm{E}-06$ \\
\hline $3-184285$ & bottle \# 11 - 20 BV & $1.23 \mathrm{E}-03$ & $7.03 \mathrm{E}-06$ \\
\hline $3-184286$ & bottle \# 12 - 20 BV & $1.69 \mathrm{E}-03$ & $9.66 \mathrm{E}-06$ \\
\hline
\end{tabular}

$*=$ by atomic absorption (AA) 
APPENDIX C2-3: ELUTION CYCLE \#2

Lead Column

Eluant $=0.5 \mathrm{M} \mathrm{HNO}$

Flow rate $=1 \mathrm{BV} / \mathrm{h}(0.18 \mathrm{~mL} / \mathrm{min}) ; \mathrm{BV}=10.8 \mathrm{~mL}$

Resin batch \# I-D5-03-06-02-35-60

Column size $=1.45 \mathrm{~cm}$

Elution samples; BV -elution based

\begin{tabular}{|c|c|c|c|}
\hline LIMS \# & BV & $\begin{array}{c}{\left[{ }^{137} \mathbf{C s}\right],} \\
\boldsymbol{H C i} / \mathbf{m L}\end{array}$ & {$\left[{ }^{137} \mathbf{C s}\right], \mathbf{C} / \mathbf{C o}$} \\
\hline $3-184879$ & 1 & $5.11 \mathrm{E}+00$ & 0.029175708 \\
\hline $3-184880$ & 2 & $1.37 \mathrm{E}+01$ & 0.078487971 \\
\hline $3-184881$ & 3 & $5.35 \mathrm{E}+03$ & 30.59252898 \\
\hline $3-184882$ & 4 & $1.26 \mathrm{E}+02$ & 0.717379229 \\
\hline $3-184883$ & 5 & $3.66 \mathrm{E}+01$ & 0.208926912 \\
\hline $3-184884$ & 7 & $1.08 \mathrm{E}+01$ & 0.06172 \\
\hline $3-184885$ & 9 & $4.77 \mathrm{E}+00$ & 0.027248571 \\
\hline $3-184886$ & 11 & $2.42 \mathrm{E}+00$ & 0.013811415 \\
\hline $3-184887$ & 13 & $1.46 \mathrm{E}+00$ & 0.00832758 \\
\hline $3-184888$ & 15 & $1.08 \mathrm{E}+00$ & 0.006165411 \\
\hline $3-184879$ & 1 & $5.11 \mathrm{E}+00$ & 0.029175708 \\
\hline $3-184880$ & 2 & $1.37 \mathrm{E}+01$ & 0.078487971 \\
\hline $3-184881$ & 3 & $5.35 \mathrm{E}+03$ & 30.59252898 \\
\hline
\end{tabular}

Dilution Factors - Eluate Cycle \#2

\begin{tabular}{|c|c|c|c|c|c|}
\hline Eluate Sample ID & LIMS \# & Water, mL & Sample, mL & $\begin{array}{l}\text { Dilution } \\
\text { Factor }\end{array}$ & $\begin{array}{c}{\left[{ }^{137} \mathrm{Cs}\right]} \\
\mu \mathrm{Ci} / \mathrm{mL}\end{array}$ \\
\hline NH-AW101-CR2-LEE-1 & $3-184879$ & 24.7315 & 0.119373777 & 208 & $2.45 \mathrm{E}-02$ \\
\hline NH-AW101-CR2-LEE-2 & $3-184880$ & 24.8013 & 0.091976517 & 271 & $5.08 \mathrm{E}-02$ \\
\hline NH-AW101-CR2-LEE-3 & $3-184881$ & 24.8161 & 0.099804305 & 250 & $2.14 \mathrm{E}+01$ \\
\hline NH-AW101-CR2-LEE-4 & $3-184882$ & 24.6724 & 0.100782779 & 246 & $5.11 \mathrm{E}-01$ \\
\hline NH-AW101-CR2-LEE-5 & $3-184883$ & 24.8062 & 0.095890411 & 260 & $1.41 \mathrm{E}-01$ \\
\hline NH-AW101-CR2-LEE-7 & $3-184884$ & no dilution & no dilution & no dilution & $1.08 \mathrm{E}+01$ \\
\hline NH-AW101-CR2-LEE-9 & $3-184885$ & no dilution & no dilution & no dilution & $4.77 \mathrm{E}+00$ \\
\hline NH-AW101-CR2-LEE-11 & $3-184886$ & 4.9538 & 0.093933464 & 54 & $4.50 \mathrm{E}-02$ \\
\hline NH-AW101-CR2-LEE-13 & $3-184887$ & 4.9778 & 0.091976517 & 55 & $2.64 \mathrm{E}-02$ \\
\hline NH-AW101-CR2-LEE-15 & $3-184888$ & 4.952 & 0.097847358 & 52 & $2.09 \mathrm{E}-02$ \\
\hline
\end{tabular}


APPENDIX C3-1: LOADING CYCLE \#3

Lead Column

Resin: SuperLig ${ }^{\circledR} 644$

Resin batch \# I-D5-03-06-02-35-60

Column size $=1.45 \mathrm{~cm} ; \mathrm{L} / \mathrm{D}=6.1$

Flow rate $=0.52 \mathrm{BV} / \mathrm{h}(0.13 \mathrm{~mL} / \mathrm{min}) ; \mathrm{BV}=15 \mathrm{~mL}$

\begin{tabular}{|c|c|c|c|c|c|}
\hline LIMS \# & $\mathbf{B V}$ & {$\left[{ }^{\mathbf{1 3 7}} \mathbf{C s}\right], \boldsymbol{\mu C i} / \mathbf{m L}$} & {$\left[{ }^{137} \mathbf{C s}\right], \mathbf{C} / \mathbf{C o}$} & {$\left[\mathbf{K}^{+}\right], \mathbf{M}$} & {$\left[\mathbf{N a}^{+}\right], \mathbf{M}$} \\
\hline $3-185717$ & 7.6 & $5.97 \mathrm{E}-02$ & $3.41 \mathrm{E}-04$ & 0.50 & 4.88 \\
\hline $3-185718$ & 15.3 & $7.98 \mathrm{E}-02$ & $4.56 \mathrm{E}-04$ & $\mathrm{~nm}$ & $\mathrm{~nm}$ \\
\hline $3-185720$ & 30.6 & $7.84 \mathrm{E}-02$ & $4.48 \mathrm{E}-04$ & $\mathrm{~nm}$ & $\mathrm{~nm}$ \\
\hline $3-185721$ & 38.2 & $3.09 \mathrm{E}-02$ & $1.77 \mathrm{E}-04$ & 0.38 & 4.01 \\
\hline $3-185722$ & 45.8 & $2.24 \mathrm{E}-02$ & $1.28 \mathrm{E}-04$ & $\mathrm{~nm}$ & $\mathrm{~nm}$ \\
\hline $3-185723$ & 53.3 & $1.95 \mathrm{E}-02$ & $1.11 \mathrm{E}-04$ & $\mathrm{~nm}$ & $\mathrm{~nm}$ \\
\hline $3-185724$ & 60.9 & $2.37 \mathrm{E}-02$ & $1.35 \mathrm{E}-04$ & $\mathrm{~nm}$ & $\mathrm{~nm}$ \\
\hline $3-185725$ & 68.4 & $1.80 \mathrm{E}-02$ & $1.03 \mathrm{E}-04$ & $\mathrm{~nm}$ & $\mathrm{~nm}$ \\
\hline $3-185726$ & 75.9 & $2.84 \mathrm{E}-02$ & $1.62 \mathrm{E}-04$ & 0.37 & 3.92 \\
\hline $3-185727$ & 83.4 & $3.02 \mathrm{E}-02$ & $1.73 \mathrm{E}-04$ & $\mathrm{~nm}$ & $\mathrm{~nm}$ \\
\hline $3-185728$ & 91.0 & $4.68 \mathrm{E}-02$ & $2.68 \mathrm{E}-04$ & $\mathrm{~nm}$ & $\mathrm{~nm}$ \\
\hline $3-185730$ & 106.0 & $5.15 \mathrm{E}-02$ & $2.94 \mathrm{E}-04$ & $\mathrm{~nm}$ & $\mathrm{~nm}$ \\
\hline $3-185731$ & 113.5 & $4.31 \mathrm{E}-02$ & $2.46 \mathrm{E}-04$ & 0.45 & 4.65 \\
\hline $3-185732$ & 121.1 & $1.86 \mathrm{E}-02$ & $1.06 \mathrm{E}-04$ & $\mathrm{~nm}$ & $\mathrm{~nm}$ \\
\hline $3-185733$ & 128.7 & $1.79 \mathrm{E}-02$ & $1.02 \mathrm{E}-04$ & $\mathrm{~nm}$ & $\mathrm{~nm}$ \\
\hline $3-185734$ & 136.3 & $2.99 \mathrm{E}-02$ & $1.71 \mathrm{E}-04$ & $\mathrm{~nm}$ & $\mathrm{~nm}$ \\
\hline $3-185735$ & 144.0 & $8.61 \mathrm{E}-02$ & $4.92 \mathrm{E}-04$ & $\mathrm{~nm}$ & $\mathrm{~nm}$ \\
\hline $3-185736$ & 151.8 & $4.85 \mathrm{E}-01$ & $2.77 \mathrm{E}-03$ & 0.42 & 4.70 \\
\hline $3-185737$ & 159.5 & $2.82 \mathrm{E}+00$ & $1.61 \mathrm{E}-02$ & $\mathrm{~nm}$ & $\mathrm{~nm}$ \\
\hline $3-185738$ & 167.1 & $1.83 \mathrm{E}+01$ & $1.04 \mathrm{E}-01$ & $\mathrm{~nm}$ & $\mathrm{~nm}$ \\
\hline $3-185739$ & 174.6 & $1.89 \mathrm{E}+01$ & $1.08 \mathrm{E}-01$ & $\mathrm{~nm}$ & $\mathrm{~nm}$ \\
\hline $3-185740$ & 182.8 & $3.44 \mathrm{E}+01$ & $1.97 \mathrm{E}-01$ & $\mathrm{~nm}$ & $\mathrm{~nm}$ \\
\hline $3-185741$ & 192.5 & $6.68 \mathrm{E}+01$ & $3.82 \mathrm{E}-01$ & 0.44 & 4.65 \\
\hline
\end{tabular}

$\mathrm{nm}-$ not measured 
APPENDIX C3-2: LOADING CYCLE \#3

Lag Column

Resin: SuperLig ${ }^{\circledR} 644$

Resin batch \# I-D5-03-06-02-35-60

Column size $=1.45 \mathrm{~cm}$

Flow rate $=0.52 \mathrm{BV} / \mathrm{h}(0.13 \mathrm{~mL} / \mathrm{min}) ; \mathrm{BV}=15 \mathrm{~mL}$

Individual Samples - Lag Column

\begin{tabular}{|c|c|c|c|}
\hline LIMS \# & \# BV Effluent & {$\left[{ }^{\mathbf{1 3 7}} \mathbf{C s}\right], \boldsymbol{\mu C i} / \mathbf{m L}$} & {$\left[{ }^{\mathbf{1 3 7}} \mathbf{C s}\right], \mathbf{C} / \mathbf{C o}$} \\
\hline $3-185742$ & 15.3 & $1.06 \mathrm{E}-02$ & $6.08 \mathrm{E}-05$ \\
\hline $3-185743$ & 30.6 & $7.14 \mathrm{E}-03$ & $4.08 \mathrm{E}-05$ \\
\hline $3-185744$ & 45.8 & $n m$ & na \\
\hline $3-185745$ & 60.9 & $5.87 \mathrm{E}-03$ & $3.35 \mathrm{E}-05$ \\
\hline $3-185746$ & 75.9 & $4.00 \mathrm{E}-03$ & $2.29 \mathrm{E}-05$ \\
\hline $3-185747$ & 91 & $9.13 \mathrm{E}-03$ & $5.22 \mathrm{E}-05$ \\
\hline $3-185748$ & 106 & $4.55 \mathrm{E}-03$ & $2.60 \mathrm{E}-05$ \\
\hline $3-185749$ & 121.1 & $8.79 \mathrm{E}-03$ & $5.02 \mathrm{E}-05$ \\
\hline $3-185750$ & 136.3 & $4.37 \mathrm{E}-03$ & $2.50 \mathrm{E}-05$ \\
\hline $3-185751$ & 151.8 & $7.85 \mathrm{E}-03$ & $4.49 \mathrm{E}-05$ \\
\hline $3-185752$ & 167.1 & $1.54 \mathrm{E}-02$ & $8.78 \mathrm{E}-05$ \\
\hline $3-185753$ & 182.8 & $2.84 \mathrm{E}-04$ & $1.62 \mathrm{E}-06$ \\
\hline
\end{tabular}

Composite Fractions - Lag Column

\begin{tabular}{|c|c|c|c|}
\hline LIMS \# & Effluent fraction \# & {$\left[{ }^{\mathbf{1 3 7}} \mathbf{C s}\right], \boldsymbol{\mu C i} / \mathbf{m L}$} & {$\left[{ }^{\mathbf{1 3 7}} \mathbf{C s}\right], \mathbf{C} / \mathbf{C o}$} \\
\hline $3-185754$ & bottle \# $1-\sim 20 \mathrm{BV}$ & $7.88 \mathrm{E}-03$ & $4.50 \mathrm{E}-05$ \\
\hline $3-185755$ & bottle \# $-\sim 20 \mathrm{BV}$ & $4.89 \mathrm{E}-03$ & $2.79 \mathrm{E}-05$ \\
\hline $3-185756$ & bottle \# $3-\sim 20 \mathrm{BV}$ & $5.62 \mathrm{E}-03$ & $3.21 \mathrm{E}-05$ \\
\hline $3-185757$ & bottle \# $4-\sim 20 \mathrm{BV}$ & $4.34 \mathrm{E}-03$ & $2.48 \mathrm{E}-05$ \\
\hline $3-185758$ & bottle \# $5-\sim 20 \mathrm{BV}$ & $3.63 \mathrm{E}-03$ & $2.07 \mathrm{E}-05$ \\
\hline $3-185759$ & bottle \# 6 - 20 BV & $4.91 \mathrm{E}-03$ & $2.81 \mathrm{E}-05$ \\
\hline $3-185760$ & bottle \# $7-\sim 20 \mathrm{BV}$ & $4.06 \mathrm{E}-03$ & $2.32 \mathrm{E}-05$ \\
\hline $3-185761$ & bottle \# $8-\sim 20 \mathrm{BV}$ & $4.28 \mathrm{E}-03$ & $2.44 \mathrm{E}-05$ \\
\hline $3-185762$ & bottle \# $9-\sim 20 \mathrm{BV}$ & $4.15 \mathrm{E}-03$ & $2.37 \mathrm{E}-05$ \\
\hline $3-185763$ & bottle \# 10 - 20 BV & $4.15 \mathrm{E}-03$ & $2.37 \mathrm{E}-05$ \\
\hline $3-185764$ & bottle \# 11 - 20 BV & $4.54 \mathrm{E}-03$ & $2.60 \mathrm{E}-05$ \\
\hline $3-185765$ & bottle \# 12 - 20 BV & $4.38 \mathrm{E}-03$ & $2.50 \mathrm{E}-05$ \\
\hline
\end{tabular}

$\mathrm{nm}=$ not measured

na $=$ not applicable 
APPENDIX C3-3: ELUTION CYCLE \#3

Lead Column

Eluant $=0.5 \mathrm{M} \mathrm{HNO}$

Flow rate $=1 \mathrm{BV} / \mathrm{h}(0.20 \mathrm{~mL} / \mathrm{min}) ; \mathrm{BV}=11.7 \mathrm{~mL}$

Resin batch \# I-D5-03-06-02-35-60

Column size $=1.45 \mathrm{~cm}$

Elution samples; BV -elution based

\begin{tabular}{|c|c|c|c|c|}
\hline LIMS \# & BV & $\begin{array}{l}\left.I^{137} \mathrm{Cs}\right] \\
\mu \mathrm{Ci} / \mathrm{mL}\end{array}$ & {$\left[{ }^{137} \mathrm{Cs}\right], \mathrm{C} / \mathrm{Co}$} & {$\left[\mathrm{Na}^{+}\right], \mathrm{M}$} \\
\hline $3-186278$ & 1 & $1.17 \mathrm{E}+00$ & $6.67 \mathrm{E}-03$ & 2.00 \\
\hline 3-186279 & 2 & $6.51 \mathrm{E}+00$ & $3.72 \mathrm{E}-02$ & 1.57 \\
\hline $3-186280$ & 3 & $4.36 \mathrm{E}+02$ & $2.49 \mathrm{E}+00$ & 1.81 \\
\hline 3-186281 & 4 & $9.78 \mathrm{E}+03$ & $5.59 \mathrm{E}+01$ & 1.53 \\
\hline 3-186282 & 5 & $1.63 \mathrm{E}+02$ & 9.33E-01 & 0.85 \\
\hline $3-186283$ & 7 & $1.26 \mathrm{E}+01$ & $7.19 \mathrm{E}-02$ & 1.81 \\
\hline 3-186284 & 9 & $1.38 \mathrm{E}+00$ & $7.90 \mathrm{E}-03$ & 2.30 \\
\hline 3-186285 & 11 & $5.06 \mathrm{E}-01$ & $2.89 \mathrm{E}-03$ & 2.40 \\
\hline $3-186286$ & 13 & 4.04E-01 & $2.31 \mathrm{E}-03$ & 2.34 \\
\hline 3-186287 & 15 & 4.94E-02 & $2.83 \mathrm{E}-04$ & 2.07 \\
\hline
\end{tabular}

Dilution Factors - Eluate Cycle \#3

\begin{tabular}{|c|c|c|c|c|c|c|}
\hline Eluate Sample ID & LIMS \# & Water, mL & Sample, mL & $\begin{array}{l}\text { Dilution } \\
\text { Factor }\end{array}$ & $\begin{array}{c}{\left[{ }^{137} \mathrm{Cs}\right]} \\
\mu \mathrm{Ci} / \mathrm{mL}\end{array}$ & $\begin{array}{l}{\left[\mathrm{Na}^{+}\right]} \\
\mathrm{mg} / \mathrm{L}\end{array}$ \\
\hline NH-AW101-CR3-LEE1 & $3-186278$ & 24.6913 & 0.108610568 & 228 & $5.11 \mathrm{E}-03$ & $2.01 \mathrm{E}+02$ \\
\hline NH-AW101-CR3-LEE2 & $3-186279$ & 24.7063 & 0.102739726 & 241 & $2.70 \mathrm{E}-02$ & $1.49 \mathrm{E}+02$ \\
\hline NH-AW101-CR3-LEE3 & $3-186280$ & 24.695 & 0.102739726 & 241 & $1.81 \mathrm{E}+00$ & $1.72 \mathrm{E}+02$ \\
\hline NH-AW101-CR3-LEE4 & $3-186281$ & 24.7232 & 0.104696673 & 237 & $4.12 \mathrm{E}+01$ & $1.48 \mathrm{E}+02$ \\
\hline NH-AW101-CR3-LEE5 & $3-186282$ & 24.6261 & 0.104696673 & 236 & $6.91 \mathrm{E}-01$ & $8.28 \mathrm{E}+01$ \\
\hline NH-AW101-CR3-LEE7 & $3-186283$ & 5.0032 & 0.101761252 & 50 & $2.51 \mathrm{E}-01$ & $8.31 \mathrm{E}+02$ \\
\hline NH-AW101-CR3-LEE9 & 3-186284 & 4.9909 & 0.112524462 & 45 & $3.05 \mathrm{E}-02$ & $1.16 \mathrm{E}+03$ \\
\hline NH-AW101-CR3-LEE11 & $3-186285$ & 5.035 & 0.112524462 & 46 & $1.11 \mathrm{E}-02$ & $1.20 \mathrm{E}+03$ \\
\hline NH-AW101-CR3-LEE13 & $3-186286$ & 4.9977 & 0.107632094 & 47 & $8.52 \mathrm{E}-03$ & $1.14 \mathrm{E}+03$ \\
\hline NH-AW101-CR3-LEE15 & $3-186287$ & 5.0072 & 0.108610568 & 47 & $1.05 \mathrm{E}-03$ & $1.01 \mathrm{E}+03$ \\
\hline
\end{tabular}


APPENDIX C4-1: LOADING CYCLE \#4

Lead Column

Resin: SuperLig ${ }^{\circledR} 644$

Resin batch \# I-D5-03-06-02-35-60

Column size $=1.45 \mathrm{~cm} ; \mathrm{L} / \mathrm{D}=6.2$

Flow rate $=0.49 \mathrm{BV} / \mathrm{h}(0.12 \mathrm{~mL} / \mathrm{min}) ; \mathrm{BV}=15 \mathrm{~mL}$

\begin{tabular}{|c|c|c|c|c|c|}
\hline LIMS \# & $\mathbf{B V}$ & $\left.{ }^{137} \mathbf{C s}\right], \boldsymbol{\mu C i} / \mathbf{m L}$ & $\left.{ }^{137} \mathbf{C s}\right], \mathbf{C} / \mathbf{C o}$ & {$\left[\mathbf{K}^{+}\right], \mathbf{M}$} & {$\left[\mathbf{N a}^{+}\right], \mathbf{M}$} \\
\hline $3-186683$ & 6.7 & $2.94 \mathrm{E}-02$ & $1.68 \mathrm{E}-04$ & 0.46 & 4.11 \\
\hline $3-186684$ & 13.4 & $2.95 \mathrm{E}-02$ & $1.68 \mathrm{E}-04$ & $\mathrm{~nm}$ & $\mathrm{~nm}$ \\
\hline $3-186685$ & 19.9 & $5.10 \mathrm{E}-02$ & $2.91 \mathrm{E}-04$ & $\mathrm{~nm}$ & $\mathrm{~nm}$ \\
\hline $3-186688$ & 40.7 & $3.87 \mathrm{E}-02$ & $2.21 \mathrm{E}-04$ & $\mathrm{~nm}$ & $\mathrm{~nm}$ \\
\hline $3-186689$ & 48.0 & $2.58 \mathrm{E}-02$ & $1.48 \mathrm{E}-04$ & $\mathrm{~nm}$ & $\mathrm{~nm}$ \\
\hline $3-186690$ & 55.1 & $1.23 \mathrm{E}-02$ & $7.03 \mathrm{E}-05$ & $\mathrm{~nm}$ & $\mathrm{~nm}$ \\
\hline $3-186691$ & 62.1 & $3.31 \mathrm{E}-02$ & $1.89 \mathrm{E}-04$ & $\mathrm{~nm}$ & $\mathrm{~nm}$ \\
\hline $3-186692$ & 69.2 & $2.26 \mathrm{E}-02$ & $1.29 \mathrm{E}-04$ & 0.45 & 4.06 \\
\hline $3-186693$ & 76.4 & $2.38 \mathrm{E}-02$ & $1.36 \mathrm{E}-04$ & $\mathrm{~nm}$ & $\mathrm{~nm}$ \\
\hline $3-186694$ & 83.7 & $2.37 \mathrm{E}-02$ & $1.35 \mathrm{E}-04$ & $\mathrm{~nm}$ & $\mathrm{~nm}$ \\
\hline $3-186695$ & 90.9 & $3.75 \mathrm{E}-02$ & $2.14 \mathrm{E}-04$ & $\mathrm{~nm}$ & $\mathrm{~nm}$ \\
\hline $3-186696$ & 98.3 & $2.02 \mathrm{E}-01$ & $1.15 \mathrm{E}-03$ & $\mathrm{~nm}$ & $\mathrm{~nm}$ \\
\hline $3-186697$ & 105.6 & $5.01 \mathrm{E}-02$ & $2.86 \mathrm{E}-04$ & 0.52 & 4.39 \\
\hline $3-186698$ & 112.9 & $2.61 \mathrm{E}-02$ & $1.49 \mathrm{E}-04$ & $\mathrm{~nm}$ & $\mathrm{~nm}$ \\
\hline $3-186699$ & 120.3 & $3.30 \mathrm{E}-02$ & $1.89 \mathrm{E}-04$ & $\mathrm{~nm}$ & $\mathrm{~nm}$ \\
\hline $3-186700$ & 127.8 & $1.22 \mathrm{E}-01$ & $6.96 \mathrm{E}-04$ & $\mathrm{~nm}$ & $\mathrm{~nm}$ \\
\hline $3-186701$ & 135.1 & $5.69 \mathrm{E}-01$ & $3.25 \mathrm{E}-03$ & $\mathrm{~nm}$ & $\mathrm{~nm}$ \\
\hline $3-186702$ & 142.4 & $6.22 \mathrm{E}+00$ & $3.55 \mathrm{E}-02$ & 0.52 & 4.57 \\
\hline $3-186703$ & 149.4 & $3.42 \mathrm{E}+01$ & $1.96 \mathrm{E}-01$ & $\mathrm{~nm}$ & $\mathrm{~nm}$ \\
\hline $3-186704$ & 156.3 & $9.57 \mathrm{E}+01$ & $5.47 \mathrm{E}-01$ & $\mathrm{~nm}$ & $\mathrm{~nm}$ \\
\hline $3-186705$ & 163.5 & $9.45 \mathrm{E}+01$ & $5.40 \mathrm{E}-01$ & $\mathrm{~nm}$ & $\mathrm{~nm}$ \\
\hline $3-186706$ & 171.0 & $4.91 \mathrm{E}+01$ & $2.81 \mathrm{E}-01$ & $\mathrm{~nm}$ & $\mathrm{~nm}$ \\
\hline
\end{tabular}

$\mathrm{nm}$ - not measured 
APPENDIX C4-2: LOADING CYCLE \#4

Lag Column

Resin: SuperLig ${ }^{\circledR} 644$

Resin batch \# I-D5-03-06-02-35-60

Column size $=1.45 \mathrm{~cm}$

Flow rate $=0.49 \mathrm{BV} / \mathrm{h}(0.12 \mathrm{~mL} / \mathrm{min}) ; \mathrm{BV}=15 \mathrm{~mL}$

Individual Samples - Lag Column

\begin{tabular}{|c|c|c|c|}
\hline LIMS \# & \# BV Effluent & $\left.{ }^{\mathbf{1 3 7}} \mathbf{C s}\right], \boldsymbol{\mu C i} / \mathbf{m L}$ & {$\left[{ }^{\mathbf{1 3 7}} \mathbf{C s}\right], \mathbf{C} / \mathbf{C o}$} \\
\hline $3-186710$ & 13.4 & $3.99 \mathrm{E}-02$ & $2.28 \mathrm{E}-04$ \\
\hline $3-186711$ & 26.5 & $6.42 \mathrm{E}-02$ & $3.67 \mathrm{E}-04$ \\
\hline $3-186712$ & 40.7 & $1.21 \mathrm{E}-02$ & $6.89 \mathrm{E}-05$ \\
\hline $3-186713$ & 55.1 & $3.53 \mathrm{E}-02$ & $2.02 \mathrm{E}-04$ \\
\hline $3-186714$ & 69.2 & $6.19 \mathrm{E}-03$ & $3.54 \mathrm{E}-05$ \\
\hline $3-186715$ & 83.7 & $4.70 \mathrm{E}-03$ & $2.69 \mathrm{E}-05$ \\
\hline $3-186716$ & 98.3 & $4.16 \mathrm{E}-03$ & $2.38 \mathrm{E}-05$ \\
\hline $3-186717$ & 112.9 & $3.60 \mathrm{E}-03$ & $2.06 \mathrm{E}-05$ \\
\hline $3-186718$ & 127.8 & $4.53 \mathrm{E}-03$ & $2.59 \mathrm{E}-05$ \\
\hline $3-186719$ & 142.4 & $3.82 \mathrm{E}-03$ & $2.19 \mathrm{E}-05$ \\
\hline $3-186720$ & 156.3 & $4.59 \mathrm{E}-03$ & $2.62 \mathrm{E}-05$ \\
\hline $3-186721$ & 171.0 & $4.14 \mathrm{E}-03$ & $2.36 \mathrm{E}-05$ \\
\hline
\end{tabular}

Composite Fractions - Lag Column

\begin{tabular}{|c|c|c|c|}
\hline LIMS \# & Effluent fraction \# & {$\left[{ }^{\mathbf{1 3 7}} \mathbf{C s}\right], \boldsymbol{\mu C i} / \mathbf{m L}$} & {$\left[{ }^{\mathbf{1 3 7}} \mathbf{C s}\right], \mathbf{C} / \mathbf{C o}$} \\
\hline $3-186951$ & bottle \# $1-\sim 20 \mathrm{BV}$ & $1.52 \mathrm{E}-02$ & $8.71 \mathrm{E}-05$ \\
\hline $3-186952$ & bottle \# $-\sim 20 \mathrm{BV}$ & $6.28 \mathrm{E}-03$ & $3.59 \mathrm{E}-05$ \\
\hline $3-186953$ & bottle \# 3 - 20 BV & $4.10 \mathrm{E}-03$ & $2.34 \mathrm{E}-05$ \\
\hline $3-186954$ & bottle \# $4-\sim 20 \mathrm{BV}$ & $3.91 \mathrm{E}-03$ & $2.23 \mathrm{E}-05$ \\
\hline $3-186955$ & bottle \# $-\sim 20 \mathrm{BV}$ & $6.76 \mathrm{E}-03$ & $3.86 \mathrm{E}-05$ \\
\hline $3-186956$ & bottle \# 6 - 20 BV & $4.62 \mathrm{E}-03$ & $2.64 \mathrm{E}-05$ \\
\hline $3-186957$ & bottle \# $7-\sim 20 \mathrm{BV}$ & $3.79 \mathrm{E}-03$ & $2.17 \mathrm{E}-05$ \\
\hline $3-186958$ & bottle \# $8-\sim 20 \mathrm{BV}$ & $3.95 \mathrm{E}-03$ & $2.25 \mathrm{E}-05$ \\
\hline $3-186959$ & bottle \# $9-\sim 20 \mathrm{BV}$ & $3.63 \mathrm{E}-03$ & $2.08 \mathrm{E}-05$ \\
\hline $3-186960$ & bottle \# 10 - 20 BV & $3.85 \mathrm{E}-03$ & $2.20 \mathrm{E}-05$ \\
\hline $3-186961$ & bottle \# 11 - 20 BV & $3.55 \mathrm{E}-03$ & $2.03 \mathrm{E}-05$ \\
\hline $3-186962$ & bottle \# 12 - 20 BV & $4.49 \mathrm{E}-03$ & $2.57 \mathrm{E}-05$ \\
\hline
\end{tabular}


APPENDIX C4-3: ELUTION CYCLE \#4

Lead Column

Eluant $=0.5 \mathrm{M} \mathrm{HNO}$

Flow rate $=\sim 1 \mathrm{BV} / \mathrm{h}(\sim 0.2 \mathrm{~mL} / \mathrm{min}) ; \mathrm{BV}=11.7 \mathrm{~mL}$

Resin batch \# I-D5-03-06-02-35-60

Column size $=1.45 \mathrm{~cm}$

Elution samples; BV -elution based

\begin{tabular}{|c|c|c|c|c|}
\hline LIMS \# & BV & $\begin{array}{c}{\left[{ }^{137} \mathbf{C s}\right],} \\
\mu \mathbf{C i} / \mathbf{m L}\end{array}$ & {$\left[{ }^{137} \mathbf{C s}\right], \mathbf{C} / \mathbf{C o}$} & {$\left[\mathbf{N a}^{+}\right], \mathbf{M}$} \\
\hline $3-187406$ & 1 & $2.79 \mathrm{E}+01$ & $1.59 \mathrm{E}-01$ & $3-187406$ \\
\hline $3-187407$ & 2 & $1.03 \mathrm{E}+01$ & $5.88 \mathrm{E}-02$ & $3-187407$ \\
\hline $3-187408$ & 3 & $5.44 \mathrm{E}+01$ & $3.11 \mathrm{E}-01$ & $3-187408$ \\
\hline $3-187409$ & 4 & $1.79 \mathrm{E}+04$ & $1.03 \mathrm{E}+02$ & $3-187409$ \\
\hline $3-187410$ & 5 & $3.09 \mathrm{E}+02$ & $1.77 \mathrm{E}+00$ & $3-187410$ \\
\hline $3-187411$ & 7 & $5.67 \mathrm{E}+00$ & $3.24 \mathrm{E}-02$ & $3-187411$ \\
\hline $3-187412$ & 9 & $2.44 \mathrm{E}+00$ & $1.39 \mathrm{E}-02$ & $3-187412$ \\
\hline $3-187413$ & 11 & $2.17 \mathrm{E}+00$ & $1.24 \mathrm{E}-02$ & $3-187413$ \\
\hline $3-187414$ & 13 & $1.43 \mathrm{E}+01$ & $8.18 \mathrm{E}-02$ & $3-187414$ \\
\hline $3-187415$ & 15 & $1.91 \mathrm{E}+01$ & $1.09 \mathrm{E}-01$ & $3-187415$ \\
\hline
\end{tabular}

Dilution Factors - Eluate Cycle \#4

\begin{tabular}{|c|c|c|c|c|c|}
\hline Eluate Sample ID & LIMS \# & $\begin{array}{c}\text { Water, } \\
\text { mL }\end{array}$ & Sample, mL & $\begin{array}{l}\text { Dilution } \\
\text { Factor }\end{array}$ & $\begin{array}{c}{\left[{ }^{137} \mathrm{Cs}\right],} \\
\mu \mathrm{Ci} / \mathrm{mL}\end{array}$ \\
\hline NH-AW101-CR4-LEE-1 & $3-187406$ & 25.2609 & 0.105675147 & 240.0429611 & $1.16 \mathrm{E}-01$ \\
\hline NH-AW101-CR4-LEE-2 & 3-187407 & 25.1093 & 0.095890411 & 262.8541286 & $3.91 \mathrm{E}-02$ \\
\hline NH-AW101-CR4-LEE-3 & 3-187408 & 25.0628 & 0.093933464 & 267.8143917 & $2.03 \mathrm{E}-01$ \\
\hline NH-AW101-CR4-LEE-4 & $3-187409$ & 25.1264 & 0.096868885 & 260.3856646 & $6.89 \mathrm{E}+01$ \\
\hline NH-AW101-CR4-LEE-5 & 3-187410 & 25.138 & 0.090019569 & 280.2503913 & $1.10 \mathrm{E}+00$ \\
\hline NH-AW101-CR4-LEE-7 & 3-187411 & 4.9791 & 0.099804305 & 50.88862941 & $1.11 \mathrm{E}-01$ \\
\hline NH-AW101-CR4-LEE-9 & $3-187412$ & 4.9626 & 0.094911937 & 53.28636289 & $4.57 \mathrm{E}-02$ \\
\hline NH-AW101-CR4-LEE-11 & 3-187413 & 4.92 & 0.094911937 & 52.83752577 & $4.10 \mathrm{E}-02$ \\
\hline NH-AW101-CR4-LEE-13 & $3-187414$ & 4.9789 & 0.089041096 & 56.91687692 & $2.52 \mathrm{E}-01$ \\
\hline NH-AW101-CR4-LEE-15 & $3-187415$ & 4.9268 & 0.102739726 & 48.95418667 & $3.89 \mathrm{E}-01$ \\
\hline
\end{tabular}


APPENDIX C5-1: LOADING CYCLE \#5

Lead Column

Resin: SuperLig ${ }^{\circledR} 644$

Resin batch \# I-D5-03-06-02-35-60

Column size $=1.45 \mathrm{~cm}, \mathrm{~L} / \mathrm{D}=6.2$

Flow rate $=0.48 \mathrm{BV} / \mathrm{h}(0.12 \mathrm{~mL} / \mathrm{min}) ; \mathrm{BV}=15 \mathrm{~mL}$

\begin{tabular}{|c|c|c|c|c|c|}
\hline LIMS \# & $\mathbf{B V}$ & {$[\mathbf{1 3 7 C s}], \boldsymbol{\mu C i} / \mathbf{m L}$} & {$[\mathbf{1 3 7 C s}], \mathbf{C} / \mathbf{C o}$} & {$\left[\mathbf{K}^{+}\right], \mathbf{M}$} & {$\left[\mathbf{N a}^{+}\right], \mathbf{M}$} \\
\hline $3-187438$ & 3.4 & $2.38 \mathrm{E}-02$ & $1.36 \mathrm{E}-04$ & 0.21 & 2.86 \\
\hline $3-187439$ & 6.7 & $2.70 \mathrm{E}-02$ & $1.54 \mathrm{E}-04$ & $\mathrm{~nm}$ & $\mathrm{~nm}$ \\
\hline $3-187440$ & 13.7 & $2.08 \mathrm{E}-02$ & $1.19 \mathrm{E}-04$ & $\mathrm{~nm}$ & $\mathrm{~nm}$ \\
\hline $3-187441$ & 20.8 & $3.80 \mathrm{E}-02$ & $2.17 \mathrm{E}-04$ & $\mathrm{~nm}$ & $\mathrm{~nm}$ \\
\hline $3-187442$ & 27.9 & $1.54 \mathrm{E}-01$ & $8.81 \mathrm{E}-04$ & $\mathrm{~nm}$ & $\mathrm{~nm}$ \\
\hline $3-187443$ & 34.9 & $1.06 \mathrm{E}-01$ & $6.04 \mathrm{E}-04$ & 0.48 & 4.52 \\
\hline $3-187444$ & 42.0 & $1.57 \mathrm{E}-02$ & $8.95 \mathrm{E}-05$ & $\mathrm{~nm}$ & $\mathrm{~nm}$ \\
\hline $3-187445$ & 49.1 & $1.69 \mathrm{E}-02$ & $9.66 \mathrm{E}-05$ & $\mathrm{~nm}$ & $\mathrm{~nm}$ \\
\hline $3-187446$ & 56.2 & $4.89 \mathrm{E}-02$ & $2.79 \mathrm{E}-04$ & $\mathrm{~nm}$ & $\mathrm{~nm}$ \\
\hline $3-187447$ & 63.2 & $2.58 \mathrm{E}-01$ & $1.47 \mathrm{E}-03$ & $\mathrm{~nm}$ & $\mathrm{~nm}$ \\
\hline $3-187448$ & 70.3 & $1.66 \mathrm{E}-01$ & $9.47 \mathrm{E}-04$ & 0.47 & 4.48 \\
\hline $3-187449$ & 77.4 & $1.78 \mathrm{E}-02$ & $1.02 \mathrm{E}-04$ & $\mathrm{~nm}$ & $\mathrm{~nm}$ \\
\hline $3-187450$ & 84.5 & $1.80 \mathrm{E}-02$ & $1.03 \mathrm{E}-04$ & $\mathrm{~nm}$ & $\mathrm{~nm}$ \\
\hline $3-187451$ & 91.5 & $7.32 \mathrm{E}-02$ & $4.19 \mathrm{E}-04$ & $\mathrm{~nm}$ & $\mathrm{~nm}$ \\
\hline $3-187452$ & 98.7 & $5.41 \mathrm{E}-02$ & $3.09 \mathrm{E}-04$ & $\mathrm{~nm}$ & $\mathrm{~nm}$ \\
\hline $3-187454$ & 105.9 & $3.79 \mathrm{E}-02$ & $2.17 \mathrm{E}-04$ & 0.57 & 5.35 \\
\hline $3-187455$ & 113.1 & $1.51 \mathrm{E}-02$ & $8.63 \mathrm{E}-05$ & $\mathrm{~nm}$ & $\mathrm{~nm}$ \\
\hline $3-187456$ & 120.5 & $1.80 \mathrm{E}-02$ & $1.03 \mathrm{E}-04$ & $\mathrm{~nm}$ & $\mathrm{~nm}$ \\
\hline $3-187457$ & 128.0 & $5.48 \mathrm{E}-02$ & $3.13 \mathrm{E}-04$ & $\mathrm{~nm}$ & $\mathrm{~nm}$ \\
\hline $3-187458$ & 135.6 & $2.21 \mathrm{E}-01$ & $1.26 \mathrm{E}-03$ & $\mathrm{~nm}$ & $\mathrm{~nm}$ \\
\hline $3-187460$ & 150.2 & $3.66 \mathrm{E}+00$ & $2.09 \mathrm{E}-02$ & $\mathrm{~nm}$ & $\mathrm{~nm}$ \\
\hline $3-187461$ & 157.6 & $1.14 \mathrm{E}+01$ & $6.50 \mathrm{E}-02$ & $\mathrm{~nm}$ & $\mathrm{~nm}$ \\
\hline $3-187462$ & 165.0 & $2.62 \mathrm{E}+01$ & $1.50 \mathrm{E}-01$ & $\mathrm{~nm}$ & $\mathrm{~nm}$ \\
\hline $3-187463$ & 172.3 & $4.97 \mathrm{E}+01$ & $2.84 \mathrm{E}-01$ & $\mathrm{~nm}$ & $\mathrm{~nm}$ \\
\hline
\end{tabular}

$\mathrm{nm}=$ not measured 
APPENDIX C5-2: LOADING CYCLE \#5

Lag Column

Resin: SuperLig ${ }^{\circledR} 644$

Resin batch \# I-D5-03-06-02-35-60

Column size $=1.45 \mathrm{~cm}$

Flow rate $=0.48 \mathrm{BV} / \mathrm{h}(0.12 \mathrm{~mL} / \mathrm{min}) ; \mathrm{BV}=15 \mathrm{~mL}$

Individual Samples - Lag Column

\begin{tabular}{|c|c|c|c|}
\hline LIMS \# & \# BV Effluent & $\left.{ }^{\mathbf{1 3 7}} \mathbf{C s}\right], \boldsymbol{\mu C i} / \mathbf{m L}$ & {$\left[{ }^{\mathbf{1 3 7}} \mathbf{C s}\right], \mathbf{C} / \mathbf{C o}$} \\
\hline $3-187469$ & 13.7 & $1.19 \mathrm{E}-02$ & $6.80 \mathrm{E}-05$ \\
\hline $3-187470$ & 27.9 & $6.61 \mathrm{E}-03$ & $3.78 \mathrm{E}-05$ \\
\hline $3-187471$ & 42 & $4.22 \mathrm{E}-03$ & $2.41 \mathrm{E}-05$ \\
\hline $3-187472$ & 56.2 & $1.51 \mathrm{E}-02$ & $8.62 \mathrm{E}-05$ \\
\hline $3-187473$ & 70.3 & $4.45 \mathrm{E}-03$ & $2.54 \mathrm{E}-05$ \\
\hline $3-187474$ & 84.5 & $7.48 \mathrm{E}-03$ & $4.27 \mathrm{E}-05$ \\
\hline $3-187475$ & 98.7 & $5.08 \mathrm{E}-03$ & $2.90 \mathrm{E}-05$ \\
\hline $3-187476$ & 113.1 & $4.34 \mathrm{E}-03$ & $2.48 \mathrm{E}-05$ \\
\hline $3-187477$ & 128 & $5.62 \mathrm{E}-03$ & $3.21 \mathrm{E}-05$ \\
\hline $3-187478$ & 142.9 & $8.80 \mathrm{E}-03$ & $5.03 \mathrm{E}-05$ \\
\hline $3-187479$ & 157.3 & $4.87 \mathrm{E}-03$ & $2.78 \mathrm{E}-05$ \\
\hline $3-187480$ & 172.3 & $4.51 \mathrm{E}-03$ & $2.58 \mathrm{E}-05$ \\
\hline
\end{tabular}

Composite Fractions - Lag Column

\begin{tabular}{|c|c|c|c|}
\hline LIMS \# & Effluent fraction \# & {$\left[{ }^{\mathbf{1 3 7}} \mathbf{C s}\right], \boldsymbol{\mu C i} / \mathbf{m L}$} & {$\left[{ }^{\mathbf{1 3 7}} \mathbf{C s}\right], \mathbf{C} / \mathbf{C o}$} \\
\hline $3-187483$ & bottle \# $1-\sim 20 \mathrm{BV}$ & $5.25 \mathrm{E}-03$ & $2.99714 \mathrm{E}-05$ \\
\hline $3-187484$ & bottle \# $2-\sim 20 \mathrm{BV}$ & $4.46 \mathrm{E}-03$ & $2.548 \mathrm{E}-05$ \\
\hline $3-187485$ & bottle \# 3 - 20 BV & $6.59 \mathrm{E}-03$ & $3.76354 \mathrm{E}-05$ \\
\hline $3-187486$ & bottle \# $4-\sim 20 \mathrm{BV}$ & $4.23 \mathrm{E}-03$ & $2.41823 \mathrm{E}-05$ \\
\hline $3-187487$ & bottle \# 5 - 20 BV & $4.35 \mathrm{E}-03$ & $2.486 \mathrm{E}-05$ \\
\hline $3-187488$ & bottle \# 6 - 20 BV & $4.08 \mathrm{E}-03$ & $2.33257 \mathrm{E}-05$ \\
\hline $3-187489$ & bottle \# 7 - 20 BV & $4.11 \mathrm{E}-03$ & $2.34726 \mathrm{E}-05$ \\
\hline $3-187490$ & bottle \# $8-\sim 20$ BV & $4.24 \mathrm{E}-03$ & $2.42514 \mathrm{E}-05$ \\
\hline $3-187491$ & bottle \# $9-\sim 20 \mathrm{BV}$ & $4.24 \mathrm{E}-03$ & $2.42109 \mathrm{E}-05$ \\
\hline $3-187492$ & bottle \# 10 - 20 BV & $4.45 \mathrm{E}-03$ & $2.54097 \mathrm{E}-05$ \\
\hline $3-187493$ & bottle \# 11 - 20 BV & $4.97 \mathrm{E}-03$ & $2.84263 \mathrm{E}-05$ \\
\hline $3-187494$ & bottle \# 12 - 20 BV & $3.86 \mathrm{E}-03$ & $2.20743 \mathrm{E}-05$ \\
\hline
\end{tabular}


APPENDIX C5-3: ELUTION CYCLE \#5

\section{Lead Column}

Eluant $=0.5 \mathrm{M} \mathrm{HNO}$

Flow rate $=\sim 1 \mathrm{BV} / \mathrm{h}(\sim 0.19 \mathrm{~mL} / \mathrm{min}) ; \mathrm{BV}=1 \mathrm{~mL}$

Resin batch \# I-D5-03-06-02-35-60

Column size $=1.45 \mathrm{~cm}$

Elution samples; BV -elution based

\begin{tabular}{|c|c|c|c|c|c|c|}
\hline LIMS \# & BV & $\begin{array}{c}{\left[{ }^{137} \mathrm{Cs}\right],} \\
\mu \mathrm{Ci} / \mathrm{mL}\end{array}$ & {$\left[{ }^{137} \mathrm{Cs}\right], \mathrm{C} / \mathrm{Co}$} & {$\left[\mathbf{K}^{+}\right], \mathbf{M}$} & {$\left[\mathrm{Na}^{+}\right], \mathbf{M}$} & pH \\
\hline 3-187497 & 1 & $9.17 \mathrm{E}-01$ & $5.24 \mathrm{E}-03$ & $<0.118$ & $5.23 \mathrm{E}-01$ & 2.61 \\
\hline $3-187498$ & 2 & $8.56 \mathrm{E}+00$ & 4.89E-02 & $\mathrm{nm}$ & $\mathrm{nm}$ & 2.60 \\
\hline 3-187499 & 3 & $5.53 \mathrm{E}+00$ & $3.16 \mathrm{E}-02$ & $<0.121$ & 5.93E-01 & 2.60 \\
\hline $3-187500$ & 4 & $1.76 \mathrm{E}+04$ & $1.00 \mathrm{E}+02$ & $\mathrm{~nm}$ & $\mathrm{~nm}$ & 2.59 \\
\hline $3-187501$ & 5 & $2.52 \mathrm{E}+02$ & $1.44 \mathrm{E}+00$ & $\mathrm{~nm}$ & $\mathrm{~nm}$ & 1.58 \\
\hline $3-187502$ & 7 & $7.51 \mathrm{E}+00$ & 4.29E-02 & $<0.025$ & $2.62 \mathrm{E}-01$ & 2.28 \\
\hline $3-187503$ & 9 & $3.95 \mathrm{E}+00$ & $2.26 \mathrm{E}-02$ & $\mathrm{~nm}$ & $\mathrm{~nm}$ & 2.26 \\
\hline $3-187504$ & 11 & $2.33 \mathrm{E}+00$ & $1.33 \mathrm{E}-02$ & $<0.025$ & $2.74 \mathrm{E}-01$ & 2.28 \\
\hline $3-187505$ & 13 & $1.72 \mathrm{E}+01$ & $9.86 \mathrm{E}-02$ & $\mathrm{~nm}$ & $\mathrm{~nm}$ & 9.30 \\
\hline $3-187506$ & 15 & $6.56 \mathrm{E}-01$ & $3.75 \mathrm{E}-03$ & $\mathrm{~nm}$ & $\mathrm{~nm}$ & 9.31 \\
\hline
\end{tabular}

\section{Dilution Factors}

\begin{tabular}{|c|c|c|c|c|c|c|c|}
\hline Eluate Sample ID & $\mathbf{L I M S ~ \#}$ & $\begin{array}{c}\text { Water, } \\
\mathbf{m L}\end{array}$ & $\begin{array}{c}\text { Sample, } \\
\mathbf{m L}\end{array}$ & $\begin{array}{l}\text { Dilution } \\
\text { Factor }\end{array}$ & $\begin{array}{c}{ }^{\mathbf{1 3 7} \mathbf{C s}],} \\
\boldsymbol{\mu} \mathbf{C i} / \mathbf{m L}\end{array}$ & $\begin{array}{c}{\left[\mathbf{K}^{+}\right],} \\
\mathbf{m g} / \mathbf{L}\end{array}$ & $\begin{array}{c}\left.\mathbf{[ N a}^{+}\right], \\
\mathbf{m g} / \mathbf{L}\end{array}$ \\
\hline NH-AW-CR5-LEE-1 & $3-187497$ & 25.2033 & 0.102739726 & 246.31212 & $3.72 \mathrm{E}-03$ & $<18.8$ & 48.8 \\
\hline NH-AW-CR5-LEE-2 & $3-187498$ & 25.0533 & 0.100782779 & 249.5871126 & $3.43 \mathrm{E}-02$ & $\mathrm{~nm}$ & $\mathrm{~nm}$ \\
\hline NH-AW-CR5-LEE-3 & $3-187499$ & 25.0327 & 0.099804305 & 251.8178373 & $2.20 \mathrm{E}-02$ & $<18.8$ & 54.2 \\
\hline NH-AW-CR5-LEE-4 & $3-187500$ & 25.052 & 0.097847358 & 257.03144 & $6.84 \mathrm{E}+01$ & $\mathrm{~nm}$ & $\mathrm{~nm}$ \\
\hline NH-AW-CR5-LEE-5 & $3-187501$ & 25.0363 & 0.095890411 & 262.0928429 & $9.60 \mathrm{E}-01$ & $\mathrm{~nm}$ & $\mathrm{~nm}$ \\
\hline NH-AW-CR5-LEE-7 & $3-187502$ & 5.0299 & 0.097847358 & 52.405578 & $1.43 \mathrm{E}-01$ & $<18.8$ & 115 \\
\hline NH-AW-CR5-LEE-9 & $3-187503$ & 5.0245 & 0.093933464 & 54.48998958 & $7.24 \mathrm{E}-02$ & $\mathrm{~nm}$ & $\mathrm{~nm}$ \\
\hline NH-AW-CR5-LEE-11 & $3-187504$ & 5.0355 & 0.097847358 & 52.46281 & $4.44 \mathrm{E}-02$ & $<18.8$ & 120 \\
\hline NH-AW-CR5-LEE-13 & $3-187505$ & 5.0333 & 0.102739726 & 49.99078667 & $3.45 \mathrm{E}-01$ & $\mathrm{~nm}$ & $\mathrm{~nm}$ \\
\hline NH-AW-CR5-LEE-15 & $3-187506$ & 5.033 & 0.1037182 & 49.52571698 & $1.32 \mathrm{E}-02$ & $\mathrm{~nm}$ & $\mathrm{~nm}$ \\
\hline
\end{tabular}


APPENDIX C6-1: LOADING CYCLE \#6

Lead Column

Resin: SuperLig ${ }^{\circledR} 644$

Resin batch \# I-D5-03-06-02-35-60

Column size $=1.45 \mathrm{~cm}, \mathrm{~L} / \mathrm{D}=6.1$

Flow rate $=0.52 \mathrm{BV} / \mathrm{h}(0.13 \mathrm{~mL} / \mathrm{min}) ; \mathrm{BV}=15 \mathrm{~mL}$

\begin{tabular}{|c|c|c|c|c|c|}
\hline LIMS \# & $\mathbf{B V}$ & {$[\mathbf{1 3 7 C}], \boldsymbol{\mu C} \mathbf{i} / \mathbf{m L}$} & {$[\mathbf{1 3 7 C s}], \mathbf{C} / \mathbf{C o}$} & {$\left[\mathbf{K}^{+}\right], \mathbf{M}$} & {$\left[\mathbf{N a}^{+}\right], \mathbf{M}$} \\
\hline 300188355 & 6.9 & $5.39 \mathrm{E}-02$ & $3.08 \mathrm{E}-04$ & 0.40 & 3.58 \\
\hline 300188356 & 14.1 & $2.09 \mathrm{E}-02$ & $1.20 \mathrm{E}-04$ & $\mathrm{~nm}$ & $\mathrm{~nm}$ \\
\hline 300188357 & 21.9 & $1.83 \mathrm{E}-02$ & $1.05 \mathrm{E}-04$ & $\mathrm{~nm}$ & $\mathrm{~nm}$ \\
\hline 300188358 & 30.2 & $2.10 \mathrm{E}-02$ & $1.20 \mathrm{E}-04$ & $\mathrm{~nm}$ & $\mathrm{~nm}$ \\
\hline 300188359 & 38.6 & $6.53 \mathrm{E}-02$ & $3.73 \mathrm{E}-04$ & 0.40 & 3.57 \\
\hline 300188360 & 47.0 & $1.47 \mathrm{E}-02$ & $8.38 \mathrm{E}-05$ & $\mathrm{~nm}$ & $\mathrm{~nm}$ \\
\hline 300188361 & 55.5 & $1.37 \mathrm{E}-02$ & $7.82 \mathrm{E}-05$ & $\mathrm{~nm}$ & $\mathrm{~nm}$ \\
\hline 300188362 & 64.0 & $5.19 \mathrm{E}-02$ & $2.96 \mathrm{E}-04$ & $\mathrm{~nm}$ & $\mathrm{~nm}$ \\
\hline 300188363 & 72.5 & $4.02 \mathrm{E}-02$ & $2.30 \mathrm{E}-04$ & $\mathrm{~nm}$ & $\mathrm{~nm}$ \\
\hline 300188364 & 80.4 & $4.33 \mathrm{E}-02$ & $2.48 \mathrm{E}-04$ & 0.39 & 3.46 \\
\hline 300188365 & 87.4 & $3.55 \mathrm{E}-02$ & $2.03 \mathrm{E}-04$ & $\mathrm{~nm}$ & $\mathrm{~nm}$ \\
\hline 300188366 & 94.6 & $3.52 \mathrm{E}-02$ & $2.01 \mathrm{E}-04$ & $\mathrm{~nm}$ & $\mathrm{~nm}$ \\
\hline 300188367 & 102.9 & $1.60 \mathrm{E}-02$ & $9.13 \mathrm{E}-05$ & $\mathrm{~nm}$ & $\mathrm{~nm}$ \\
\hline 300188368 & 111.8 & $4.42 \mathrm{E}-02$ & $2.53 \mathrm{E}-04$ & $\mathrm{~nm}$ & $\mathrm{~nm}$ \\
\hline 300188369 & 120.8 & $3.85 \mathrm{E}-01$ & $2.20 \mathrm{E}-03$ & 0.48 & 3.98 \\
\hline 300188370 & 129.4 & $1.36 \mathrm{E}+00$ & $7.76 \mathrm{E}-03$ & $\mathrm{~nm}$ & $\mathrm{~nm}$ \\
\hline 300188371 & 137.5 & $4.55 \mathrm{E}+00$ & $2.60 \mathrm{E}-02$ & $\mathrm{~nm}$ & $\mathrm{~nm}$ \\
\hline 300188372 & 145.2 & $1.11 \mathrm{E}+01$ & $6.37 \mathrm{E}-02$ & $\mathrm{~nm}$ & $\mathrm{~nm}$ \\
\hline 300188373 & 152.6 & $2.07 \mathrm{E}+01$ & $1.19 \mathrm{E}-01$ & $\mathrm{~nm}$ & $\mathrm{~nm}$ \\
\hline 300188374 & 160.0 & $6.24 \mathrm{E}+01$ & $3.56 \mathrm{E}-01$ & 0.47 & 3.97 \\
\hline 300188375 & 167.5 & $9.28 \mathrm{E}+01$ & $5.30 \mathrm{E}-01$ & $\mathrm{~nm}$ & $\mathrm{~nm}$ \\
\hline 300188376 & 174.6 & $1.33 \mathrm{E}+02$ & $7.62 \mathrm{E}-01$ & $\mathrm{~nm}$ & $\mathrm{~nm}$ \\
\hline
\end{tabular}

$\mathrm{nm}=$ not measured 
APPENDIX C6-2: LOADING CYCLE \#6

Lag Column

Resin: SuperLig ${ }^{\circledR} 644$

Resin batch \# I-D5-03-06-02-35-60

Column size $=1.45 \mathrm{~cm}$

Flow rate $=0.52 \mathrm{BV} / \mathrm{h}(0.12 \mathrm{~mL} / \mathrm{min}) ; \mathrm{BV}=15 \mathrm{~mL}$

Individual Samples - Lag Column

\begin{tabular}{|c|c|c|c|}
\hline LIMS \# & \# BV Effluent & {$\left[{ }^{\mathbf{1 3 7}} \mathbf{C s}\right], \boldsymbol{\mu C i} / \mathbf{m L}$} & {$\left[{ }^{\mathbf{1 3 7}} \mathbf{C s}\right], \mathbf{C} / \mathbf{C o}$} \\
\hline $3-188384$ & 14.1 & $4.95 \mathrm{E}-03$ & $2.83 \mathrm{E}-05$ \\
\hline $3-188385$ & 30.2 & $4.21 \mathrm{E}-03$ & $2.41 \mathrm{E}-05$ \\
\hline $3-188386$ & 47.0 & $4.52 \mathrm{E}-03$ & $2.58 \mathrm{E}-05$ \\
\hline $3-188387$ & 64.0 & $5.30 \mathrm{E}-03$ & $3.03 \mathrm{E}-05$ \\
\hline $3-188388$ & 80.4 & $9.85 \mathrm{E}-03$ & $5.63 \mathrm{E}-05$ \\
\hline $3-188389$ & 94.6 & $1.72 \mathrm{E}-02$ & $9.84 \mathrm{E}-05$ \\
\hline $3-188390$ & 111.8 & $3.94 \mathrm{E}-03$ & $2.25 \mathrm{E}-05$ \\
\hline $3-188391$ & 129.4 & $4.46 \mathrm{E}-03$ & $2.55 \mathrm{E}-05$ \\
\hline $3-188392$ & 145.2 & $3.77 \mathrm{E}-02$ & $2.15 \mathrm{E}-04$ \\
\hline $3-188393$ & 160.0 & $2.94 \mathrm{E}-02$ & $1.68 \mathrm{E}-04$ \\
\hline $3-188394$ & 174.6 & $6.00 \mathrm{E}-03$ & $3.43 \mathrm{E}-05$ \\
\hline $3-188395$ & 186.1 & $6.15 \mathrm{E}-03$ & $3.51 \mathrm{E}-05$ \\
\hline $3-188396$ & 197.0 & $6.40 \mathrm{E}-03$ & $3.66 \mathrm{E}-05$ \\
\hline
\end{tabular}

Composite Fractions - Lag Column

\begin{tabular}{|c|c|c|c|}
\hline LIMS \# & Effluent fraction \# & {$\left[{ }^{\mathbf{1 3 7}} \mathbf{C s}\right], \boldsymbol{\mu C i} / \mathbf{m L}$} & {$\left[{ }^{\mathbf{1 3 7}} \mathbf{C s}\right], \mathbf{C} / \mathbf{C o}$} \\
\hline $3-188398$ & bottle \# $1-\sim 20 \mathrm{BV}$ & $7.27 \mathrm{E}-03$ & $4.16 \mathrm{E}-05$ \\
\hline $3-188399$ & bottle \# $2-\sim 20 \mathrm{BV}$ & $3.93 \mathrm{E}-03$ & $2.24 \mathrm{E}-05$ \\
\hline $3-188400$ & bottle \# $3-\sim 20 \mathrm{BV}$ & $3.71 \mathrm{E}-03$ & $2.12 \mathrm{E}-05$ \\
\hline $3-188401$ & bottle \# $4-\sim 20 \mathrm{BV}$ & $3.37 \mathrm{E}-03$ & $1.93 \mathrm{E}-05$ \\
\hline $3-188402$ & bottle \# 5 - 20 BV & $3.49 \mathrm{E}-03$ & $1.99 \mathrm{E}-05$ \\
\hline $3-188403$ & bottle \# 6 - 20 BV & $3.70 \mathrm{E}-03$ & $2.11 \mathrm{E}-05$ \\
\hline $3-188404$ & bottle \# 7 - 20 BV & $3.57 \mathrm{E}-03$ & $2.04 \mathrm{E}-05$ \\
\hline $3-188405$ & bottle \# $8-\sim 20 \mathrm{BV}$ & $3.40 \mathrm{E}-03$ & $1.94 \mathrm{E}-05$ \\
\hline $3-188406$ & bottle \# $9-\sim 20 \mathrm{BV}$ & $3.51 \mathrm{E}-03$ & $2.00 \mathrm{E}-05$ \\
\hline $3-188407$ & bottle \# 10 - 20 BV & $4.38 \mathrm{E}-03$ & $2.50 \mathrm{E}-05$ \\
\hline $3-188408$ & bottle \# 11 - 20 BV & $3.54 \mathrm{E}-03$ & $2.03 \mathrm{E}-05$ \\
\hline $3-188409$ & bottle \# 12 - 20 BV & $4.22 \mathrm{E}-03$ & $2.41 \mathrm{E}-05$ \\
\hline
\end{tabular}


APPENDIX C6-3: ELUTION CYCLE \#6

\section{Lead Column}

\section{Eluant $=0.5 \mathrm{M} \mathrm{HNO}$}

Flow rate $=\sim 1 \mathrm{BV} / \mathrm{h}(\sim 0.19 \mathrm{~mL} / \mathrm{min}) ; \mathrm{BV}=11.4 \mathrm{~mL}$

Resin batch \# I-D5-03-06-02-35-60

Column size $=1.45 \mathrm{~cm}$

\section{Elution samples; BV -elution based}

\begin{tabular}{|c|c|c|c|c|c|c|}
\hline $\mathbf{L I M S} \#$ & $\mathbf{B V}$ & $\begin{array}{c}\left.\mathbf{I}^{\mathbf{1 3 7}} \mathbf{C s}\right], \\
\boldsymbol{\mu} \mathbf{C i} \mathbf{m L}\end{array}$ & $\left.{ }^{\mathbf{1 3 7}} \mathbf{C s}\right], \mathbf{C} / \mathbf{C o}$ & {$\left[\mathbf{K}^{+}\right], \mathbf{M}$} & {$\left[\mathbf{N a}^{+}\right], \mathbf{M}$} & $\mathbf{p H}$ \\
\hline $3-188413$ & 1 & $2.48 \mathrm{E}+01$ & $1.42 \mathrm{E}-01$ & $<0.1375$ & 0.84 & 2.54 \\
\hline $3-188414$ & 2 & $1.50 \mathrm{E}+01$ & $8.59 \mathrm{E}-02$ & $<0.1226$ & 0.57 & 2.59 \\
\hline $3-188415$ & 3 & $2.55 \mathrm{E}+04$ & $1.46 \mathrm{E}+02$ & $<0.1226$ & 0.48 & 2.59 \\
\hline $3-188416$ & 4 & $3.94 \mathrm{E}+02$ & $2.25 \mathrm{E}+00$ & $<0.1241$ & 0.28 & 2.59 \\
\hline $3-188417$ & 5 & $1.04 \mathrm{E}+02$ & $5.92 \mathrm{E}-01$ & $<0.1265$ & 0.31 & 1.58 \\
\hline $3-188418$ & 7 & $1.27 \mathrm{E}+01$ & $7.28 \mathrm{E}-02$ & 0.0298478 & 0.22 & 2.27 \\
\hline $3-188419$ & 9 & $4.34 \mathrm{E}+00$ & $2.48 \mathrm{E}-02$ & 0.0347861 & 0.26 & 2.29 \\
\hline $3-188420$ & 11 & $1.11 \mathrm{E}+01$ & $6.32 \mathrm{E}-02$ & 0.1118847 & 1.24 & $\mathbf{7 . 3 1}$ \\
\hline $3-188421$ & 13 & $3.60 \mathrm{E}+00$ & $2.05 \mathrm{E}-02$ & 0.027201 & 0.22 & 2.28 \\
\hline $3-188958$ & 16 & $4.95 \mathrm{E}+00$ & $2.83 \mathrm{E}-02$ & $n \mathrm{~nm}$ & $\mathrm{~nm}$ & $\mathrm{~nm}$ \\
\hline
\end{tabular}

\section{Dilution Factors}

\begin{tabular}{|c|c|c|c|c|c|c|c|c|}
\hline $\begin{array}{l}\text { Eluate } \\
\text { Sample ID }\end{array}$ & LIMS \# & $\begin{array}{c}\text { Water, } \\
\text { mL }\end{array}$ & $\begin{array}{c}\text { Sample, } \\
\text { mL }\end{array}$ & $\begin{array}{l}\text { Dilution } \\
\text { Factor }\end{array}$ & $\begin{array}{l}{\left[{ }^{137} \mathrm{Cs}\right],} \\
\mu \mathrm{Ci} / \mathrm{mL}\end{array}$ & $\begin{array}{l}{\left[{ }^{137} \mathrm{Cs}\right],} \\
\mu \mathrm{Ci} / \mathrm{mL}\end{array}$ & {$\left[\mathbf{K}^{+}\right], \mathbf{m g} / \mathbf{L}$} & $\begin{array}{l}{\left[\mathrm{Na}^{+}\right]} \\
\mathbf{m g} / \mathbf{L}\end{array}$ \\
\hline $\begin{array}{l}\text { NH-AW101-CR6- } \\
\text { LEE-1 }\end{array}$ & $3-188413$ & 25.1047 & 0.088062622 & 286 & $8.66 \mathrm{E}-02$ & $2.48 \mathrm{E}+01$ & $<18.8$ & $<5376.8$ \\
\hline $\begin{array}{l}\text { NH-AW101-CR6- } \\
\text { LEE-2 }\end{array}$ & 3-188414 & 24.8541 & 0.097847358 & 255 & $5.90 \mathrm{E}-02$ & $1.50 \mathrm{E}+01$ & $<18.8$ & $<4794$ \\
\hline $\begin{array}{l}\text { NH-AW101-CR6- } \\
\text { LEE-3 }\end{array}$ & 3-188415 & 24.8826 & 0.097847358 & 255 & $9.99 \mathrm{E}+01$ & $2.55 \mathrm{E}+04$ & $<18.8$ & $<4794$ \\
\hline $\begin{array}{l}\text { NH-AW101-CR6- } \\
\text { LEE-4 }\end{array}$ & 3-188416 & 24.8596 & 0.096868885 & 258 & $1.53 \mathrm{E}+00$ & $3.94 \mathrm{E}+02$ & $<18.8$ & $<4850.4$ \\
\hline $\begin{array}{l}\text { NH-AW101-CR6- } \\
\text { LEE-5 }\end{array}$ & 3-188417 & 24.8266 & 0.094911937 & 263 & $3.95 \mathrm{E}-01$ & $1.04 \mathrm{E}+02$ & $<18.8$ & $<4944.4$ \\
\hline $\begin{array}{l}\text { NH-AW101-CR6- } \\
\text { LEE-7 }\end{array}$ & 3-188418 & 5.0141 & 0.095890411 & 53 & $2.39 \mathrm{E}-01$ & $1.27 \mathrm{E}+01$ & 21.9 & 1167.0488 \\
\hline $\begin{array}{l}\text { NH-AW101-CR6- } \\
\text { LEE-9 }\end{array}$ & 3-188419 & 4.9654 & 0.099804305 & 51 & $8.55 \mathrm{E}-02$ & $4.34 \mathrm{E}+00$ & 26.8 & 1360.1365 \\
\hline $\begin{array}{c}\text { NH-AW101-CR6- } \\
\text { LEE-11 }\end{array}$ & 3-188420 & 4.983 & 0.1037182 & 49 & $2.26 \mathrm{E}-01$ & $1.11 \mathrm{E}+01$ & 89.2 & 4374.6928 \\
\hline $\begin{array}{c}\text { NH-AW101-CR6- } \\
\text { LEE-13 }\end{array}$ & 3-188421 & 4.9783 & 0.096868885 & 52 & $6.86 \mathrm{E}-02$ & $3.60 \mathrm{E}+00$ & 20.3 & 1063.5606 \\
\hline $\begin{array}{l}\text { NH-AW101-CR6- } \\
\text { LEE-15 }\end{array}$ & $3-188422$ & 4.9913 & $\mathrm{~nm}$ & $\mathrm{~nm}$ & $4.75 \mathrm{E}+00$ & $\mathrm{~nm}$ & $\mathrm{~nm}$ & $\mathrm{~nm}$ \\
\hline
\end{tabular}

$\mathrm{nm}=$ not measured 
WSRC-TR-2003-00098, REVISION 0

SRT-RPP-2003-00026, REVISION 0

\section{APPENDIX D - TECHNETIUM LOADING AND ELUTION DATA}

\section{APPENDIX D1-1: LOADING CYCLE \#1}

\section{Lead Column}

Resin: SuperLig ${ }^{\circledR} 639$

Resin Batch \# I-R2-03-27-02-20-45

Column size $=1.45 \mathrm{~cm}$

Flow rate $=3 \mathrm{BV} / \mathrm{h}(0.6 \mathrm{~mL} / \mathrm{min}) ; \mathrm{BV}=12 \mathrm{~mL}$

\begin{tabular}{|c|c|c|c|c|c|c|}
\hline LIMS \# & BV & $\begin{array}{l}\text { [Tc-99], } \\
\text { dpm/mL }\end{array}$ & $\begin{array}{l}{[\mathrm{Tc}-99]} \\
\mu \mathrm{Ci} / \mathrm{mL}\end{array}$ & [Tc-99], $\mu \mathrm{g} / \mathrm{L}$ & [Tc-99],C/Co & {$\left[\mathrm{NO}_{3}{ }^{-}\right], \mathrm{M}$} \\
\hline $3-186327$ & 5 & $3.82 \mathrm{E}+01$ & $1.74 \mathrm{E}-05$ & $1.01 \mathrm{E}+00$ & $2.60 \mathrm{E}-04$ & $\mathrm{~nm}$ \\
\hline $3-186328$ & 10 & $3.83 \mathrm{E}+01$ & $1.74 \mathrm{E}-05$ & $1.02 \mathrm{E}+00$ & $2.61 \mathrm{E}-04$ & 1.35 \\
\hline $3-186329$ & 20 & $5.15 \mathrm{E}+01$ & $2.34 \mathrm{E}-05$ & $1.36 \mathrm{E}+00$ & $3.50 \mathrm{E}-04$ & $\mathrm{~nm}$ \\
\hline $3-186330$ & 30 & $5.01 \mathrm{E}+01$ & $2.28 \mathrm{E}-05$ & $1.33 \mathrm{E}+00$ & $3.41 \mathrm{E}-04$ & $\mathrm{~nm}$ \\
\hline $3-186331$ & 40 & $6.76 \mathrm{E}+01$ & $3.07 \mathrm{E}-05$ & $1.79 \mathrm{E}+00$ & $4.60 \mathrm{E}-04$ & 1.44 \\
\hline $3-186332$ & 50 & $8.64 \mathrm{E}+01$ & $3.93 \mathrm{E}-05$ & $2.29 \mathrm{E}+00$ & $5.88 \mathrm{E}-04$ & $\mathrm{~nm}$ \\
\hline $3-186333$ & 60 & $1.27 \mathrm{E}+02$ & 5.77E-05 & $3.35 \mathrm{E}+00$ & $8.64 \mathrm{E}-04$ & $\mathrm{~nm}$ \\
\hline $3-186334$ & 70 & $2.12 \mathrm{E}+02$ & $9.64 \mathrm{E}-05$ & $5.62 \mathrm{E}+00$ & $1.44 \mathrm{E}-03$ & $\mathrm{~nm}$ \\
\hline $3-186335$ & 80 & $3.31 \mathrm{E}+02$ & $1.50 \mathrm{E}-04$ & $8.76 \mathrm{E}+00$ & $2.25 \mathrm{E}-03$ & 0.71 \\
\hline $3-186336$ & 90 & $3.41 \mathrm{E}+02$ & $1.55 \mathrm{E}-04$ & $9.04 \mathrm{E}+00$ & $2.32 \mathrm{E}-03$ & $\mathrm{~nm}$ \\
\hline $3-186337$ & 100 & $4.55 \mathrm{E}+02$ & $2.07 \mathrm{E}-04$ & $1.21 \mathrm{E}+01$ & $3.10 \mathrm{E}-03$ & $\mathrm{~nm}$ \\
\hline $3-186532$ & 110 & $9.82 \mathrm{E}+02$ & $4.46 \mathrm{E}-04$ & $2.60 \mathrm{E}+01$ & $6.68 \mathrm{E}-03$ & $\mathrm{~nm}$ \\
\hline $3-186338$ & 120 & $9.79 \mathrm{E}+02$ & $4.45 \mathrm{E}-04$ & $2.59 \mathrm{E}+01$ & $6.66 \mathrm{E}-03$ & $\mathrm{~nm}$ \\
\hline $3-186339$ & 130 & $1.47 \mathrm{E}+03$ & $6.68 \mathrm{E}-04$ & $3.89 \mathrm{E}+01$ & $1.00 \mathrm{E}-02$ & 1.04 \\
\hline $3-186340$ & 140 & $1.61 \mathrm{E}+03$ & $7.32 \mathrm{E}-04$ & $4.26 \mathrm{E}+01$ & $1.10 \mathrm{E}-02$ & $\mathrm{~nm}$ \\
\hline $3-186341$ & 150 & $2.21 \mathrm{E}+03$ & $1.00 \mathrm{E}-03$ & $5.86 \mathrm{E}+01$ & $1.50 \mathrm{E}-02$ & $\mathrm{~nm}$ \\
\hline 3-186342 & 160 & $2.72 \mathrm{E}+03$ & $1.24 \mathrm{E}-03$ & $7.21 \mathrm{E}+01$ & $1.85 \mathrm{E}-02$ & 1.21 \\
\hline $3-186343$ & 170 & $2.51 \mathrm{E}+03$ & $1.14 \mathrm{E}-03$ & $6.65 \mathrm{E}+01$ & $1.71 \mathrm{E}-02$ & $\mathrm{~nm}$ \\
\hline $3-186344$ & 180 & $3.71 \mathrm{E}+03$ & $1.69 \mathrm{E}-03$ & $9.82 \mathrm{E}+01$ & $2.52 \mathrm{E}-02$ & $\mathrm{~nm}$ \\
\hline $3-186345$ & 190 & $3.67 \mathrm{E}+03$ & $1.67 \mathrm{E}-03$ & $9.71 \mathrm{E}+01$ & $2.50 \mathrm{E}-02$ & $\mathrm{~nm}$ \\
\hline $3-186346$ & 200 & $5.00 \mathrm{E}+03$ & $2.27 \mathrm{E}-03$ & $1.32 \mathrm{E}+02$ & $3.40 \mathrm{E}-02$ & 1.12 \\
\hline $3-186347$ & 210 & $4.97 \mathrm{E}+03$ & $2.26 \mathrm{E}-03$ & $1.32 \mathrm{E}+02$ & $3.38 \mathrm{E}-02$ & $\mathrm{~nm}$ \\
\hline 3-186348 & 220 & $8.60 \mathrm{E}+03$ & $3.91 \mathrm{E}-03$ & $2.28 \mathrm{E}+02$ & $5.85 \mathrm{E}-02$ & $\mathrm{~nm}$ \\
\hline 3-186349 & 230 & $1.07 \mathrm{E}+04$ & $4.86 \mathrm{E}-03$ & $2.82 \mathrm{E}+02$ & $7.28 \mathrm{E}-02$ & $\mathrm{~nm}$ \\
\hline
\end{tabular}


APPENDIX D1-2: LOADING CYCLE \#1

Lead Column

Resin: SuperLig ${ }^{\circledR} 639$

Resin batch \# I-R2-03-27-02-20-45

Column size $=1.45 \mathrm{~cm}$

Flow rate $=3 \mathrm{BV} / \mathrm{h}(0.6 \mathrm{~mL} / \mathrm{min}) ; \mathrm{BV}=12 \mathrm{~mL}$

Individual Samples - Lag Column

\begin{tabular}{|c|c|c|c|c|}
\hline LIMS \# & BV & {$[$ Tc-99], $\mathbf{d p m} / \mathbf{m L}$} & {$[\mathbf{T c - 9 9 ] ,} \boldsymbol{\mu g} / \mathbf{L}$} & C/Co \\
\hline $3-186360$ & 40 & $2.81 \mathrm{E}+01$ & $7.45 \mathrm{E}-01$ & $1.91 \mathrm{E}-04$ \\
\hline $3-186361$ & 60 & $7.40 \mathrm{E}+01$ & $1.96 \mathrm{E}+00$ & $5.03 \mathrm{E}-04$ \\
\hline $3-186362$ & 80 & $7.51 \mathrm{E}+01$ & $1.99 \mathrm{E}+00$ & $5.11 \mathrm{E}-04$ \\
\hline $3-186363$ & 100 & $6.23 \mathrm{E}+01$ & $1.65 \mathrm{E}+00$ & $4.24 \mathrm{E}-04$ \\
\hline $3-186364$ & 120 & $5.55 \mathrm{E}+01$ & $1.47 \mathrm{E}+00$ & $3.78 \mathrm{E}-04$ \\
\hline $3-186365$ & 140 & $4.55 \mathrm{E}+01$ & $1.21 \mathrm{E}+00$ & $3.10 \mathrm{E}-04$ \\
\hline $3-186366$ & 160 & $2.27 \mathrm{E}+01$ & $6.02 \mathrm{E}-01$ & $1.54 \mathrm{E}-04$ \\
\hline $3-186367$ & 180 & $4.13 \mathrm{E}+01$ & $1.09 \mathrm{E}+00$ & $2.81 \mathrm{E}-04$ \\
\hline $3-186368$ & 200 & $4.39 \mathrm{E}+01$ & $1.16 \mathrm{E}+00$ & $2.99 \mathrm{E}-04$ \\
\hline $3-186369$ & 220 & $1.66 \mathrm{E}+01$ & $4.39 \mathrm{E}-01$ & $1.13 \mathrm{E}-04$ \\
\hline
\end{tabular}

Composite Fractions - Lag Column

\begin{tabular}{|c|c|c|c|c|c|c|}
\hline LIMS \# & Effluent fraction \# & $\begin{array}{l}{[\mathrm{Tc-99],} \mathrm{*}} \\
\mathrm{dpm} / \mathrm{mL}\end{array}$ & $\begin{array}{c}\text { [Tc-99], } \\
\mu \mathrm{g} / \mathrm{L}\end{array}$ & $\mathrm{C} / \mathrm{Co}$ & $\begin{array}{c}\text { [Tc-99], ** } \\
\text { mg/L }\end{array}$ & {$\left[\mathbf{K}^{+}\right], \mathbf{M}$} \\
\hline $3-186374$ & bottle \# $1-\sim 20 \mathrm{BV}$ & $3.30 \mathrm{E}+01$ & $8.73 \mathrm{E}-01$ & $2.24 \mathrm{E}-04$ & $<120$ & $4.05 \mathrm{E}-01$ \\
\hline $3-186375$ & bottle \# 2 - 20 BV & $3.76 \mathrm{E}+01$ & $9.96 \mathrm{E}-01$ & $2.56 \mathrm{E}-04$ & $<150$ & 4.79E-01 \\
\hline $3-186376$ & bottle \# 3 - 20 BV & $6.12 \mathrm{E}+01$ & $1.62 \mathrm{E}+00$ & 4.16E-04 & NA & NA \\
\hline $3-186377$ & bottle \# 4 - 20 BV & $1.25 \mathrm{E}+01$ & $3.32 \mathrm{E}-01$ & $8.50 \mathrm{E}-05$ & $<120$ & $4.69 \mathrm{E}-01$ \\
\hline $3-186378$ & bottle \# 5 - 20 BV & $1.07 \mathrm{E}+01$ & $2.83 \mathrm{E}-01$ & $7.28 \mathrm{E}-05$ & $<122.5$ & 4.62E-01 \\
\hline $3-186379$ & bottle \# $6-\sim 20 \mathrm{BV}$ & $5.91 \mathrm{E}+01$ & $1.56 \mathrm{E}+00$ & 4.02E-04 & $<600$ & $5.03 \mathrm{E}-01$ \\
\hline $3-186380$ & bottle \# 7 - 20 BV & $2.90 \mathrm{E}+04$ & $7.69 \mathrm{E}+02$ & $1.97 \mathrm{E}-01$ & $<1200$ & $3.13 \mathrm{E}-02$ \\
\hline $3-187431$ & bottle \# $8-\sim 20 \mathrm{BV}$ & $8.88 \mathrm{E}+01$ & $2.35 \mathrm{E}+00$ & $6.04 \mathrm{E}-04$ & NA & NA \\
\hline $3-187432$ & bottle \# 9 - 20 BV & $8.41 \mathrm{E}+01$ & $2.23 \mathrm{E}+00$ & $5.72 \mathrm{E}-04$ & NA & NA \\
\hline
\end{tabular}

* by separation/counting

** by ICP-AES 
APPENDIX D1-3: WASHING CYCLE \#1

Lag Column

Resin: SuperLig ${ }^{\circledR} 639$

Resin batch \# I-R2-03-27-02-20-45

Column size $=1.45 \mathrm{~cm}$

Flow rate $=3 \mathrm{BV} / \mathrm{h}(0.6 \mathrm{~mL} / \mathrm{min}) ; \mathrm{BV}=12 \mathrm{~mL}$

AW-101 Wash with 0.1 NaOH (Feed Displacement)

\begin{tabular}{|c|c|c|c|c|c|c|c|c|c|}
\hline Sample & LIMS \# & BV & $\begin{array}{l}\text { [Tc-99], } \\
\text { dpm/mL }\end{array}$ & $\begin{array}{c}\text { [Tc-99], * } \\
\mu \mathrm{g} / \mathrm{L}\end{array}$ & $\begin{array}{c}\text { [Tc-99], } \\
\text { C/Co }\end{array}$ & $\begin{array}{c}{[\text { Tc-99], ** }} \\
\mu \mathrm{g} / \mathrm{L}\end{array}$ & [Tc-99], M & {$[\mathbf{K}+], \mathbf{M}$} & {$[\mathbf{N a}+], \mathbf{M}$} \\
\hline wash-1 & $3-186533$ & 0.50 & $1.15 \mathrm{E}+04$ & $3.05 \mathrm{E}+02$ & 7.82E-02 & $3.22 \mathrm{E}+02$ & $3.25 \mathrm{E}-06$ & 4.92E-01 & $4.48 \mathrm{E}+00$ \\
\hline wash-2 & 3-186534 & 1.00 & $6.62 \mathrm{E}+03$ & $1.75 \mathrm{E}+02$ & $4.50 \mathrm{E}-02$ & $3.40 \mathrm{E}+02$ & $3.43 \mathrm{E}-06$ & $4.59 \mathrm{E}-01$ & $4.29 \mathrm{E}+00$ \\
\hline wash-3 & $3-186535$ & 1.50 & $7.66 \mathrm{E}+03$ & $2.03 \mathrm{E}+02$ & $5.21 \mathrm{E}-02$ & $3.13 \mathrm{E}+02$ & $3.16 \mathrm{E}-06$ & $3.38 \mathrm{E}-01$ & $3.17 \mathrm{E}+00$ \\
\hline wash-4 & 3-186536 & 2.00 & $8.84 \mathrm{E}+03$ & $2.34 \mathrm{E}+02$ & $6.01 \mathrm{E}-02$ & $2.59 \mathrm{E}+02$ & $2.62 \mathrm{E}-06$ & $1.09 \mathrm{E}-01$ & $1.01 \mathrm{E}+00$ \\
\hline wash-5 & 3-186537 & 2.50 & $5.00 \mathrm{E}+03$ & $1.33 \mathrm{E}+02$ & $3.40 \mathrm{E}-02$ & $1.57 \mathrm{E}+02$ & $1.59 \mathrm{E}-06$ & $8.28 \mathrm{E}-02$ & $4.06 \mathrm{E}-01$ \\
\hline wash-6 & $3-186538$ & 3.00 & $2.55 \mathrm{E}+03$ & $6.75 \mathrm{E}+01$ & $1.73 \mathrm{E}-02$ & $1.02 \mathrm{E}+02$ & $1.03 \mathrm{E}-06$ & $6.67 \mathrm{E}-02$ & $2.46 \mathrm{E}-01$ \\
\hline wash-7 & 3-186539 & 3.50 & $2.63 \mathrm{E}+03$ & $6.97 \mathrm{E}+01$ & $1.79 \mathrm{E}-02$ & $9.80 \mathrm{E}+01$ & $9.90 \mathrm{E}-07$ & $4.49 \mathrm{E}-02$ & $2.11 \mathrm{E}-01$ \\
\hline wash-8 & $3-186540$ & 4.00 & $2.58 \mathrm{E}+04$ & $6.84 \mathrm{E}+02$ & $1.76 \mathrm{E}-01$ & $1.15 \mathrm{E}+02$ & $1.16 \mathrm{E}-06$ & $2.69 \mathrm{E}-02$ & $1.94 \mathrm{E}-01$ \\
\hline
\end{tabular}

* by separation/counting

** by ICP-AES 


\section{APPENDIX D1-4: ELUTION CYCLE \#1}

\section{Lead Column}

Eluant - DI Water

Temperature $-65^{\circ} \mathrm{C}$

Flow rate $=\sim 1 \mathrm{BV} / \mathrm{h}(0.2 \mathrm{~mL} / \mathrm{min}) ; \mathrm{BV}=12 \mathrm{~mL}$

Resin batch \# I-R2-03-27-02-20-45

Column size $=1.45 \mathrm{~cm}$

\begin{tabular}{|c|c|c|c|c|c|c|c|c|c|}
\hline LIMS \# & BV & $\begin{array}{l}\text { [Tc-99], } \\
\text { dpm/mL }\end{array}$ & $\begin{array}{c}\text { [Tc-99], * } \\
\mu \mathrm{g} / \mathrm{L}\end{array}$ & $\begin{array}{c}\text { [Tc-99], } \\
\text { C/Co }\end{array}$ & $\begin{array}{c}\text { [Tc-99], } \\
\mu \mathrm{g} / \mathrm{L}\end{array}$ & $\begin{array}{c}\text { [Tc-99], ** } \\
\text { C/Co }\end{array}$ & [Tc-99], M & {$[\mathbf{K}+], \mathbf{M}$} & {$[\mathbf{N a}+], \mathbf{M}$} \\
\hline $3-186542$ & 0.5 & $2.33 \mathrm{E}+05$ & $6.18 \mathrm{E}+03$ & $1.59 \mathrm{E}+00$ & $7.81 \mathrm{E}+03$ & $1.95 \mathrm{E}+00$ & $7.88 \mathrm{E}-05$ & 1.63E-02 & $1.09 \mathrm{E}-01$ \\
\hline $3-186543$ & 1 & $5.65 \mathrm{E}+05$ & $1.50 \mathrm{E}+04$ & $3.84 \mathrm{E}+00$ & $1.67 \mathrm{E}+04$ & $4.16 \mathrm{E}+00$ & $1.68 \mathrm{E}-04$ & $9.90 \mathrm{E}-03$ & $9.87 \mathrm{E}-02$ \\
\hline $3-186544$ & 1.5 & $1.33 \mathrm{E}+06$ & $3.52 \mathrm{E}+04$ & $9.05 \mathrm{E}+00$ & $3.89 \mathrm{E}+04$ & $9.71 \mathrm{E}+00$ & 3.92E-04 & $5.49 \mathrm{E}-03$ & $4.12 \mathrm{E}-02$ \\
\hline $3-186545$ & 2 & NA & NA & \#VALUE! & $2.72 \mathrm{E}+05$ & $6.80 \mathrm{E}+01$ & $2.75 \mathrm{E}-03$ & $2.97 \mathrm{E}-03$ & $1.26 \mathrm{E}-02$ \\
\hline $3-186546$ & 2.5 & $1.39 \mathrm{E}+07$ & $3.69 \mathrm{E}+05$ & $9.46 \mathrm{E}+01$ & $4.79 \mathrm{E}+05$ & $1.20 \mathrm{E}+02$ & 4.84E-03 & $1.82 \mathrm{E}-03$ & $7.96 \mathrm{E}-03$ \\
\hline $3-186547$ & 3 & $8.96 \mathrm{E}+06$ & $2.38 \mathrm{E}+05$ & $6.10 \mathrm{E}+01$ & $2.83 \mathrm{E}+05$ & $7.06 \mathrm{E}+01$ & $2.85 \mathrm{E}-03$ & 2.19E-03 & 4.07E-03 \\
\hline $3-186548$ & 3.5 & $7.00 \mathrm{E}+06$ & $1.85 \mathrm{E}+05$ & $4.76 \mathrm{E}+01$ & $2.17 \mathrm{E}+05$ & $5.41 \mathrm{E}+01$ & $2.19 \mathrm{E}-03$ & $3.08 \mathrm{E}-03$ & $2.32 \mathrm{E}-03$ \\
\hline $3-186549$ & 4 & $6.56 \mathrm{E}+06$ & $1.74 \mathrm{E}+05$ & $4.46 \mathrm{E}+01$ & $2.00 \mathrm{E}+05$ & $5.00 \mathrm{E}+01$ & $2.02 \mathrm{E}-03$ & $3.10 \mathrm{E}-03$ & $1.73 \mathrm{E}-03$ \\
\hline $3-186550$ & 6 & $1.91 \mathrm{E}+06$ & $5.05 \mathrm{E}+04$ & $1.30 \mathrm{E}+01$ & $5.58 \mathrm{E}+04$ & $1.39 \mathrm{E}+01$ & 5.64E-04 & $1.63 \mathrm{E}-03$ & $1.27 \mathrm{E}-03$ \\
\hline $3-186551$ & 8 & $7.09 \mathrm{E}+04$ & $1.88 \mathrm{E}+03$ & $4.82 \mathrm{E}-01$ & $2.02 \mathrm{E}+03$ & $5.03 \mathrm{E}-01$ & $2.04 \mathrm{E}-05$ & $8.23 \mathrm{E}-04$ & $1.24 \mathrm{E}-03$ \\
\hline 3-186552 & 10 & $4.85 \mathrm{E}+03$ & $1.28 \mathrm{E}+02$ & $3.30 \mathrm{E}-02$ & $1.17 \mathrm{E}+02$ & 2.92E-02 & $1.18 \mathrm{E}-06$ & $<4.82 \mathrm{E}-04$ & $9.39 \mathrm{E}-04$ \\
\hline 3-186553 & 12 & $1.86 \mathrm{E}+03$ & $4.94 \mathrm{E}+01$ & $1.27 \mathrm{E}-02$ & $<1.2 \mathrm{E}+02$ & $<3.00 \mathrm{E}-02$ & $<6.06 \mathrm{E}-07$ & $<4.82 \mathrm{E}-04$ & $8.57 \mathrm{E}-04$ \\
\hline $3-186554$ & 14 & $1.38 \mathrm{E}+03$ & $3.65 \mathrm{E}+01$ & $9.39 \mathrm{E}-03$ & $<1.2 \mathrm{E}+02$ & $<3.00 \mathrm{E}-02$ & $<6.06 \mathrm{E}-07$ & $<4.82 \mathrm{E}-04$ & $7.70 \mathrm{E}-04$ \\
\hline 3-186555 & 16 & $\mathbf{n m}$ & $\mathbf{n m}$ & $\mathbf{n m}$ & $<1.2 \mathrm{E}+02$ & $<3.00 \mathrm{E}-02$ & $<6.06 \mathrm{E}-07$ & $<4.82 \mathrm{E}-04$ & $7.57 E-04$ \\
\hline 3-186556 & 18 & $7.18 \mathrm{E}+02$ & $1.90 \mathrm{E}+01$ & $4.88 \mathrm{E}-03$ & $<1.2 \mathrm{E}+02$ & $<3.00 \mathrm{E}-02$ & $<1.21 \mathrm{E}-06$ & $<4.82 \mathrm{E}-04$ & $6.22 \mathrm{E}-04$ \\
\hline 3-186526 & 20 & $5.68 \mathrm{E}+02$ & $1.50 \mathrm{E}+01$ & $3.86 \mathrm{E}-03$ & $<1.2 \mathrm{E}+02$ & $<3.00 \mathrm{E}-02$ & $<1.21 \mathrm{E}-06$ & $<4.82 \mathrm{E}-04$ & $7.57 \mathrm{E}-04$ \\
\hline $3-186527$ & 22 & $5.53 \mathrm{E}+02$ & $1.47 \mathrm{E}+01$ & $3.76 \mathrm{E}-03$ & $<1.2 \mathrm{E}+02$ & $<3.00 \mathrm{E}-02$ & $<1.21 \mathrm{E}-06$ & $<4.82 \mathrm{E}-04$ & 8.61E-04 \\
\hline 3-186528 & 24 & $4.06 \mathrm{E}+02$ & $1.08 \mathrm{E}+01$ & $2.76 \mathrm{E}-03$ & $<1.2 \mathrm{E}+02$ & $<3.00 \mathrm{E}-02$ & $<1.21 \mathrm{E}-06$ & $<4.82 \mathrm{E}-04$ & $6.43 \mathrm{E}-04$ \\
\hline 3-186529 & 26 & $4.52 \mathrm{E}+02$ & $1.20 \mathrm{E}+01$ & 3.07E-03 & $<1.2 \mathrm{E}+02$ & $<3.00 \mathrm{E}-02$ & $<1.21 \mathrm{E}-06$ & $<4.82 \mathrm{E}-04$ & $6.00 \mathrm{E}-04$ \\
\hline
\end{tabular}

* by separation/counting

** by ICP-AES 
APPENDIX D2-1: LOADING CYCLE \#2

\section{Lead Column}

Resin: SuperLig ${ }^{\circledR} 639$

Resin Batch \# I-R2-03-27-02-20-45
Column size $=1.45 \mathrm{~cm}$

Flow rate $=3 \mathrm{BV} / \mathrm{h}(0.6 \mathrm{~mL} / \mathrm{min})$

$\mathrm{BV}=12 \mathrm{~mL}$

\begin{tabular}{|c|c|c|c|c|c|c|c|c|}
\hline \multirow[b]{2}{*}{ LIMS \# } & \multirow[b]{2}{*}{ \# BV effluent } & \multicolumn{2}{|c|}{ By Counting } & \multicolumn{5}{|c|}{ By ICP-AES } \\
\hline & & $\begin{array}{l}\text { [Tc-99], } \\
\text { dpm/mL }\end{array}$ & $\begin{array}{l}\text { [Tc-99], } \\
\mu \mathrm{Ci} / \mathbf{m L}\end{array}$ & {$[\mathrm{Tc}-99], \mu \mathrm{g} / \mathrm{L}$} & [Tc-99],C/Co & [Tc-99], M & {$[\mathbf{K}+], \mathbf{M}$} & {$[\mathrm{Na}+], \mathrm{M}$} \\
\hline $3-186815$ & 10 & $3.65 \mathrm{E}+02$ & $1.66 \mathrm{E}-04$ & $9.68 \mathrm{E}+00$ & $2.48 \mathrm{E}-03$ & $<1.20 \mathrm{E}-06$ & $3.49 \mathrm{E}-01$ & $3.50 \mathrm{E}+00$ \\
\hline 3-186816 & 20 & $2.90 \mathrm{E}+02$ & $1.32 \mathrm{E}-04$ & $7.67 \mathrm{E}+00$ & $1.97 \mathrm{E}-03$ & $<1.20 \mathrm{E}-06$ & $4.79 \mathrm{E}-01$ & $4.96 \mathrm{E}+00$ \\
\hline 3-186817 & 30 & $2.81 \mathrm{E}+02$ & $1.28 \mathrm{E}-04$ & $7.45 \mathrm{E}+00$ & $1.91 \mathrm{E}-03$ & NA & NA & NA \\
\hline 3-186818 & 40 & $3.23 \mathrm{E}+02$ & $1.47 \mathrm{E}-04$ & $8.57 \mathrm{E}+00$ & $2.20 \mathrm{E}-03$ & NA & NA & $\mathrm{NA}$ \\
\hline 3-186819 & 50 & $3.24 \mathrm{E}+02$ & $1.47 \mathrm{E}-04$ & $8.58 \mathrm{E}+00$ & $2.20 \mathrm{E}-03$ & NA & NA & NA \\
\hline 3-186820 & 60 & $3.46 \mathrm{E}+02$ & $1.57 \mathrm{E}-04$ & $9.17 \mathrm{E}+00$ & $2.35 \mathrm{E}-03$ & $<1.20 \mathrm{E}-06$ & $4.85 \mathrm{E}-01$ & $4.87 \mathrm{E}+00$ \\
\hline 3-186821 & 70 & $4.77 \mathrm{E}+02$ & $2.17 \mathrm{E}-04$ & $1.26 \mathrm{E}+01$ & $3.24 \mathrm{E}-03$ & NA & NA & NA \\
\hline 3-186822 & 80 & $6.59 \mathrm{E}+02$ & $3.00 \mathrm{E}-04$ & $1.75 \mathrm{E}+01$ & $4.48 \mathrm{E}-03$ & NA & NA & NA \\
\hline 3-186823 & 90 & $7.15 \mathrm{E}+02$ & $3.25 \mathrm{E}-04$ & $1.90 \mathrm{E}+01$ & $4.86 \mathrm{E}-03$ & NA & NA & NA \\
\hline 3-186824 & 100 & $9.47 \mathrm{E}+02$ & $4.30 \mathrm{E}-04$ & $2.51 \mathrm{E}+01$ & $6.44 \mathrm{E}-03$ & $<1.20 \mathrm{E}-06$ & $4.74 \mathrm{E}-01$ & $4.91 \mathrm{E}+00$ \\
\hline 3-186825 & 110 & $2.64 \mathrm{E}+04$ & $1.20 \mathrm{E}-02$ & $3.88 \mathrm{E}+01$ & $1.80 \mathrm{E}-01$ & NA & NA & NA \\
\hline 3-186826 & 120 & $1.68 \mathrm{E}+03$ & 7.64E-04 & $4.44 \mathrm{E}+01$ & $1.14 \mathrm{E}-02$ & NA & NA & NA \\
\hline 3-186827 & 130 & $2.06 \mathrm{E}+03$ & $9.36 \mathrm{E}-04$ & $5.46 \mathrm{E}+01$ & $1.40 \mathrm{E}-02$ & NA & NA & NA \\
\hline 3-186828 & 140 & $2.57 \mathrm{E}+03$ & $1.17 \mathrm{E}-03$ & $6.81 \mathrm{E}+01$ & $1.75 \mathrm{E}-02$ & NA & NA & NA \\
\hline 3-186829 & 150 & $4.30 \mathrm{E}+03$ & $1.95 \mathrm{E}-03$ & $1.14 \mathrm{E}+02$ & $2.93 \mathrm{E}-02$ & $2.20 \mathrm{E}-06$ & 4.79E-01 & $4.91 \mathrm{E}+00$ \\
\hline 3-186830 & 160 & $5.12 \mathrm{E}+03$ & $2.33 \mathrm{E}-03$ & $1.36 \mathrm{E}+02$ & $3.48 \mathrm{E}-02$ & NA & NA & NA \\
\hline 3-186831 & 170 & $6.11 \mathrm{E}+03$ & $2.78 \mathrm{E}-03$ & $1.62 \mathrm{E}+02$ & $4.16 \mathrm{E}-02$ & NA & NA & NA \\
\hline 3-186832 & 180 & $7.28 \mathrm{E}+07$ & $3.31 \mathrm{E}+01$ & $1.85 \mathrm{E}+02$ & $4.95 \mathrm{E}+02$ & $2.50 \mathrm{E}-06$ & 4.64E-01 & $4.96 \mathrm{E}+00$ \\
\hline 3-186833 & 190 & $9.10 \mathrm{E}+03$ & $4.14 \mathrm{E}-03$ & $2.41 \mathrm{E}+02$ & $6.19 \mathrm{E}-02$ & NA & NA & NA \\
\hline 3-186834 & 200 & $8.35 \mathrm{E}+03$ & $3.80 \mathrm{E}-03$ & $2.21 \mathrm{E}+02$ & $5.68 \mathrm{E}-02$ & NA & NA & NA \\
\hline 3-186835 & 210 & $9.64 \mathrm{E}+03$ & $4.38 \mathrm{E}-03$ & $2.55 \mathrm{E}+02$ & $6.56 \mathrm{E}-02$ & $2.20 \mathrm{E}-06$ & 4.64E-01 & $4.87 \mathrm{E}+00$ \\
\hline 3-186836 & 220 & $1.02 \mathrm{E}+04$ & 4.64E-03 & $2.70 \mathrm{E}+02$ & $6.94 \mathrm{E}-02$ & NA & NA & NA \\
\hline 3-186837 & 230 & $9.22 \mathrm{E}+03$ & $4.19 \mathrm{E}-03$ & $2.44 \mathrm{E}+02$ & $6.27 \mathrm{E}-02$ & NA & NA & NA \\
\hline 3-186838 & 240 & $9.96 \mathrm{E}+03$ & $4.53 \mathrm{E}-03$ & $2.64 \mathrm{E}+02$ & $6.78 \mathrm{E}-02$ & NA & NA & NA \\
\hline 3-186839 & 250 & $1.52 \mathrm{E}+04$ & $6.91 \mathrm{E}-03$ & $4.02 \mathrm{E}+02$ & $1.03 \mathrm{E}-01$ & $3.30 \mathrm{E}-06$ & $4.62 \mathrm{E}-01$ & $4.96 \mathrm{E}+00$ \\
\hline 3-186840 & 260 & $1.96 \mathrm{E}+04$ & $8.91 \mathrm{E}-03$ & $5.20 \mathrm{E}+02$ & $1.33 \mathrm{E}-01$ & NA & NA & NA \\
\hline 3-186841 & 270 & $1.31 \mathrm{E}+04$ & $5.95 \mathrm{E}-03$ & $3.46 \mathrm{E}+02$ & 8.91E-02 & NA & NA & NA \\
\hline 3-186842 & 280 & $1.02 \mathrm{E}+04$ & 4.64E-03 & $2.69 \mathrm{E}+02$ & $6.94 \mathrm{E}-02$ & NA & NA & NA \\
\hline
\end{tabular}


APPENDIX D2-2: LOADING CYCLE \#2

Lag Column

Resin: SuperLig ${ }^{\circledR} 639$

Resin Batch \# I-R2-03-27-02-20-45
Column size $=1.45 \mathrm{~cm}$

Flow rate $=3 \mathrm{BV} / \mathrm{h}(0.6 \mathrm{~mL} / \mathrm{min})$

$B V=12 \mathrm{~mL}$

Individual Samples - Lag Column

\begin{tabular}{|c|c|c|c|c|}
\hline LIMS \# & \# BV effluent & [Tc-99], dpm/mL & Tc-99, $\mu \mathrm{g} / \mathrm{L}$ & $\mathrm{C} / \mathrm{Co}$ \\
\hline $3-186845$ & 20 & $5.46 \mathrm{E}+02$ & $<14.5$ & $3.71 \mathrm{E}-03$ \\
\hline $3-186846$ & 40 & $4.11 \mathrm{E}+02$ & $<10.9$ & $2.80 \mathrm{E}-03$ \\
\hline $3-186847$ & 60 & $2.94 \mathrm{E}+02$ & $<7.78$ & $2.00 \mathrm{E}-03$ \\
\hline $3-186848$ & 80 & $3.30 \mathrm{E}+02$ & $<8.74$ & 2.24E-03 \\
\hline $3-186849$ & 100 & $5.86 \mathrm{E}+02$ & $<15.5$ & $3.99 \mathrm{E}-03$ \\
\hline $3-186850$ & 120 & $3.86 \mathrm{E}+02$ & $<10.2$ & $2.63 \mathrm{E}-03$ \\
\hline $3-186851$ & 140 & $5.33 \mathrm{E}+02$ & $<14.1$ & $3.63 \mathrm{E}-03$ \\
\hline $3-186852$ & 160 & $2.96 \mathrm{E}+02$ & $<7.84$ & $2.01 \mathrm{E}-03$ \\
\hline $3-186853$ & 180 & $3.94 \mathrm{E}+02$ & $<10.5$ & $2.68 \mathrm{E}-03$ \\
\hline $3-186854$ & 200 & $1.83 \mathrm{E}+02$ & $<4.85$ & $1.24 \mathrm{E}-03$ \\
\hline $3-186855$ & 220 & $1.61 \mathrm{E}+02$ & $<4.28$ & $1.10 \mathrm{E}-03$ \\
\hline $3-186856$ & 240 & $1.81 \mathrm{E}+02$ & $<4.8$ & $1.23 \mathrm{E}-03$ \\
\hline 3-186857 & 260 & $2.43 \mathrm{E}+02$ & $<6.43$ & $1.65 \mathrm{E}-03$ \\
\hline $3-186858$ & 280 & $2.63 \mathrm{E}+02$ & $<6.96$ & $1.79 \mathrm{E}-03$ \\
\hline
\end{tabular}

\section{Composite Fraction}

\begin{tabular}{|c|c|c|c|c|}
\hline LIMS \# & Effluent Fraction & [Tc-99], dpm/mL & Tc-99, $\mu \mathrm{g} / \mathrm{L}$ & $\mathrm{C} / \mathrm{Co}$ \\
\hline $3-186860$ & bottle \# $1-\sim 20 \mathrm{BV}$ & $2.48 \mathrm{E}+02$ & $<6.56$ & $1.69 \mathrm{E}-03$ \\
\hline $3-186861$ & bottle \# $2-\sim 20 \mathrm{BV}$ & $2.62 \mathrm{E}+02$ & $<6.95$ & $1.78 \mathrm{E}-03$ \\
\hline 3-186862 & bottle \# $3-\sim 20 \mathrm{BV}$ & $4.20 \mathrm{E}+02$ & $<11.1$ & $2.86 \mathrm{E}-03$ \\
\hline $3-186863$ & bottle \# $4-\sim 20$ BV & $2.43 \mathrm{E}+02$ & $<6.43$ & $1.65 \mathrm{E}-03$ \\
\hline $3-186864$ & bottle \# $5-\sim 20 \mathrm{BV}$ & $2.11 \mathrm{E}+02$ & $<5.58$ & $1.44 \mathrm{E}-03$ \\
\hline $3-186865$ & bottle \# $6-\sim 20 \mathrm{BV}$ & $1.64 \mathrm{E}+02$ & $<4.35$ & $1.12 \mathrm{E}-03$ \\
\hline $3-186866$ & bottle \# $7-\sim 20 \mathrm{BV}$ & $2.12 \mathrm{E}+02$ & $<5.61$ & $1.44 \mathrm{E}-03$ \\
\hline $3-186867$ & bottle \# $8-\sim 20 \mathrm{BV}$ & $8.88 \mathrm{E}+01$ & & 6.04E-04 \\
\hline
\end{tabular}


APPENDIX D2-3: WASHING CYCLE \#2

\section{Lag Column}

Resin: SuperLig ${ }^{\circledR} 639$

Resin Batch \# I-R2-03-27-02-20-45
Column size $=1.45 \mathrm{~cm}$

Flow rate $=3 \mathrm{BV} / \mathrm{h}(0.6 \mathrm{~mL} / \mathrm{min})$

$\mathrm{BV}=12 \mathrm{~mL}$

Feed Displacement - 0.1 NaOH

\begin{tabular}{|c|c|c|c|c|c|c|c|c|c|c|}
\hline Sample & LIMS \# & BV & $\begin{array}{l}\text { [Tc-99], } \\
\text { dpm/mL }\end{array}$ & $\begin{array}{c}\text { Tc-99], } \\
\mu \mathrm{g} / \mathrm{L}\end{array}$ & $\begin{array}{c}\text { [Tc-99], } \\
\text { C/Co } \\
\end{array}$ & $\begin{array}{c}\text { [Tc-99], } \\
\mu \mathrm{g} / \mathrm{L}\end{array}$ & [Tc-99], M & {$\left[\mathbf{K}^{+}\right], \mathbf{M}$} & {$\left[\mathrm{Na}^{+}\right], \mathrm{M}$} & {$\left[\mathrm{NO}_{3}{ }^{-}\right], \mathrm{M}$} \\
\hline wash-1 & $3-186922$ & 0.50 & $1.91 \mathrm{E}+04$ & $5.05 \mathrm{E}+02$ & $1.30 \mathrm{E}-01$ & $3.86 \mathrm{E}+02$ & $3.89 \mathrm{E}-06$ & 4.49E-01 & $4.61 \mathrm{E}+00$ & $6.26 \mathrm{E}-01$ \\
\hline wash-2 & $3-186923$ & 1.00 & $1.74 \mathrm{E}+04$ & $4.62 \mathrm{E}+02$ & $1.18 \mathrm{E}-01$ & $4.00 \mathrm{E}+02$ & $4.04 \mathrm{E}-06$ & $1.89 \mathrm{E}-01$ & $2.24 \mathrm{E}+00$ & 8.06E-01 \\
\hline wash-3 & 3-186924 & 1.50 & $1.52 \mathrm{E}+04$ & $4.03 \mathrm{E}+02$ & $1.03 \mathrm{E}-01$ & $2.32 \mathrm{E}+02$ & $2.34 \mathrm{E}-06$ & $9.38 \mathrm{E}-02$ & 7.57E-01 & $3.10 \mathrm{E}-01$ \\
\hline wash-4 & $3-186925$ & 2.00 & $7.27 \mathrm{E}+03$ & $1.93 \mathrm{E}+02$ & $4.95 \mathrm{E}-02$ & $1.12 \mathrm{E}+02$ & $1.13 \mathrm{E}-06$ & $7.72 \mathrm{E}-02$ & $2.67 \mathrm{E}-01$ & $1.41 \mathrm{E}-01$ \\
\hline wash-5 & $3-186926$ & 2.50 & $6.03 \mathrm{E}+03$ & $1.60 \mathrm{E}+02$ & $4.10 \mathrm{E}-02$ & $8.80 \mathrm{E}+01$ & 8.89E-07 & $5.85 \mathrm{E}-02$ & $1.65 \mathrm{E}-01$ & $8.11 \mathrm{E}-02$ \\
\hline wash-6 & $3-186927$ & 3.00 & $6.57 \mathrm{E}+03$ & $1.74 \mathrm{E}+02$ & 4.47E-02 & $<1.2 \mathrm{E}+03$ & $<1.21 \mathrm{E}+06$ & $3.85 \mathrm{E}-02$ & $1.38 \mathrm{E}-01$ & $4.50 \mathrm{E}-02$ \\
\hline wash-7 & $3-186928$ & 3.50 & $9.01 \mathrm{E}+03$ & $2.39 \mathrm{E}+02$ & $6.13 \mathrm{E}-02$ & $1.53 \mathrm{E}+02$ & $1.55 \mathrm{E}-06$ & 2.29E-02 & $1.25 \mathrm{E}-01$ & $2.21 \mathrm{E}-02$ \\
\hline wash-8 & $3-186929$ & 4.00 & $1.34 \mathrm{E}+04$ & $3.54 \mathrm{E}+02$ & $9.12 \mathrm{E}-02$ & $2.75 \mathrm{E}+02$ & $2.77 \mathrm{E}-06$ & $1.33 \mathrm{E}-02$ & $1.17 \mathrm{E}-01$ & $1.34 \mathrm{E}-02$ \\
\hline
\end{tabular}




\section{APPENDIX D}

WSRC-TR-2003-00098, REVISION 0

SRT-RPP-2003-00026, REVISION 0

APPENDIX D2-4: ELUTION CYCLE \#2

\section{Lead Column}

Eluant $=$ DI Water

Resin Batch \# I-R2-03-27-02-20-45

Column size $=1.45 \mathrm{~cm}$

Flow rate $=\sim 1 \mathrm{BV} / \mathrm{h}(0.2 \mathrm{~mL} / \mathrm{min}) ; \mathrm{BV}=12 \mathrm{~mL}$

Temperature $=65^{\circ} \mathrm{C}$

\section{Elution Samples}

\begin{tabular}{|c|c|c|c|c|c|c|c|c|c|}
\hline LIMS \# & BV & $\begin{array}{l}\text { [Tc-99], } \\
\text { dpm/mL }\end{array}$ & $\begin{array}{c}{[\mathrm{Tc-99}]} \\
\mu \mathrm{g} / \mathrm{L}\end{array}$ & $\begin{array}{c}\text { [Tc-99], } \\
\text { C/Co }\end{array}$ & $\begin{array}{c}{[\text { Tc-99], }} \\
\mu \mathrm{g} / \mathrm{L}\end{array}$ & $\begin{array}{c}\text { [Tc-99], } \\
\text { C/Co }\end{array}$ & [Tc-99], М & {$[\mathbf{K}+], \mathbf{M}$} & {$[\mathbf{N a}+], \mathbf{M}$} \\
\hline $3-186930$ & 0.5 & $3.88 \mathrm{E}+05$ & $1.03 \mathrm{E}+04$ & $2.64 \mathrm{E}+00$ & $1.02 \mathrm{E}+04$ & $2.54 \mathrm{E}+00$ & $1.03 \mathrm{E}-04$ & $1.18 \mathrm{E}-02$ & $1.10 \mathrm{E}-01$ \\
\hline $3-186931$ & 1 & $8.87 \mathrm{E}+05$ & $2.35 \mathrm{E}+04$ & $6.03 \mathrm{E}+00$ & $2.29 \mathrm{E}+04$ & $5.72 \mathrm{E}+00$ & $2.31 \mathrm{E}-04$ & $9.79 \mathrm{E}-03$ & $1.03 \mathrm{E}-01$ \\
\hline $3-186932$ & 1.5 & $1.94 \mathrm{E}+06$ & $5.01 \mathrm{E}+07$ & $1.32 \mathrm{E}+01$ & $5.46 \mathrm{E}+04$ & $1.36 \mathrm{E}+01$ & $5.51 \mathrm{E}-04$ & $5.08 \mathrm{E}-03$ & $4.57 \mathrm{E}-02$ \\
\hline $3-186933$ & 2 & $4.63 \mathrm{E}+06$ & $1.23 \mathrm{E}+05$ & $3.15 \mathrm{E}+01$ & $1.30 \mathrm{E}+05$ & $3.24 \mathrm{E}+01$ & $1.31 \mathrm{E}-03$ & $3.41 \mathrm{E}-03$ & $1.28 \mathrm{E}-02$ \\
\hline $3-186934$ & 2.5 & $1.34 \mathrm{E}+07$ & $3.54 \mathrm{E}+05$ & $9.12 \mathrm{E}+01$ & $3.60 \mathrm{E}+05$ & $8.99 \mathrm{E}+01$ & $3.64 \mathrm{E}-03$ & $2.09 \mathrm{E}-03$ & $6.35 \mathrm{E}-03$ \\
\hline $3-186935$ & 3 & $9.77 \mathrm{E}+06$ & $2.59 \mathrm{E}+05$ & $6.65 \mathrm{E}+01$ & $2.97 \mathrm{E}+05$ & $7.41 \mathrm{E}+01$ & $2.99 \mathrm{E}-03$ & $2.67 \mathrm{E}-03$ & $3.68 \mathrm{E}-03$ \\
\hline $3-186936$ & 3.5 & $9.15 \mathrm{E}+06$ & $2.42 \mathrm{E}+05$ & $6.22 \mathrm{E}+01$ & $2.52 \mathrm{E}+05$ & $6.28 \mathrm{E}+01$ & $2.54 \mathrm{E}-03$ & $3.10 \mathrm{E}-03$ & $2.15 \mathrm{E}-03$ \\
\hline $3-186937$ & 4 & $8.78 \mathrm{E}+06$ & $2.33 \mathrm{E}+05$ & $5.97 \mathrm{E}+01$ & $2.50 \mathrm{E}+05$ & $6.23 \mathrm{E}+01$ & $2.52 \mathrm{E}-03$ & $3.62 \mathrm{E}-03$ & $1.59 \mathrm{E}-03$ \\
\hline 3-186938 & 6 & $4.93 \mathrm{E}+06$ & $1.31 \mathrm{E}+05$ & $3.35 \mathrm{E}+01$ & $1.33 \mathrm{E}+05$ & $3.31 \mathrm{E}+01$ & $1.34 \mathrm{E}-03$ & $2.55 \mathrm{E}-03$ & $1.63 \mathrm{E}-03$ \\
\hline 3-186939 & 8 & $7.50 \mathrm{E}+05$ & $1.99 \mathrm{E}+04$ & $5.10 \mathrm{E}+00$ & $2.00 \mathrm{E}+04$ & $4.98 \mathrm{E}+00$ & $2.02 \mathrm{E}-04$ & $9.87 \mathrm{E}-04$ & $1.81 \mathrm{E}-03$ \\
\hline $3-186940$ & 10 & $2.04 \mathrm{E}+04$ & $5.41 \mathrm{E}+02$ & $1.39 \mathrm{E}-01$ & $5.89 \mathrm{E}+02$ & $1.47 \mathrm{E}-01$ & $5.95 \mathrm{E}-06$ & $<4.82 \mathrm{E}-04$ & $1.50 \mathrm{E}-03$ \\
\hline $3-186941$ & 12 & $5.23 \mathrm{E}+03$ & $1.39 \mathrm{E}+02$ & $3.56 \mathrm{E}-02$ & $<1.67+02$ & $<4.17 \mathrm{E}-02$ & $<1.69 \mathrm{E}-06$ & $<4.82 \mathrm{E}-04$ & $9.22 \mathrm{E}-04$ \\
\hline 3-186942 & 14 & $2.30 \mathrm{E}+03$ & $6.10 \mathrm{E}+01$ & $1.56 \mathrm{E}-02$ & $<1.2 \mathrm{E}+02$ & $<3.00 \mathrm{E}-02$ & $<1.21 \mathrm{E}-06$ & $<4.82 \mathrm{E}-04$ & $8.52 \mathrm{E}-04$ \\
\hline $3-186943$ & 16 & $1.46 \mathrm{E}+03$ & $3.88 \mathrm{E}+01$ & $9.93 \mathrm{E}-03$ & $<1.2 \mathrm{E}+02$ & $<3.00 \mathrm{E}-02$ & $<1.21 \mathrm{E}-06$ & $<4.82 \mathrm{E}-04$ & 7.65E-04 \\
\hline $3-186944$ & 18 & $1.16 \mathrm{E}+03$ & $3.07 \mathrm{E}+01$ & $7.89 \mathrm{E}-03$ & $<1.2 \mathrm{E}+02$ & $<3.00 \mathrm{E}-02$ & $<1.21 \mathrm{E}-06$ & $<4.82 \mathrm{E}-04$ & 7.87E-04 \\
\hline 3-186945 & 20 & $9.31 \mathrm{E}+02$ & $2.47 \mathrm{E}+01$ & $6.33 \mathrm{E}-03$ & $<1.2 \mathrm{E}+02$ & $<3.00 \mathrm{E}-02$ & $<1.21 \mathrm{E}-06$ & $<4.82 \mathrm{E}-04$ & $6.43 \mathrm{E}-04$ \\
\hline $3-186946$ & 22 & $7.82 \mathrm{E}+02$ & $2.07 \mathrm{E}+01$ & $5.32 \mathrm{E}-03$ & $<1.2 \mathrm{E}+02$ & $<3.00 \mathrm{E}-02$ & $<1.21 \mathrm{E}-06$ & $<4.82 \mathrm{E}-04$ & $5.70 \mathrm{E}-04$ \\
\hline $3-186947$ & 24 & $7.08 \mathrm{E}+02$ & $1.88 \mathrm{E}+01$ & $4.82 \mathrm{E}-03$ & $<1.2 \mathrm{E}+02$ & $<3.00 \mathrm{E}-02$ & $<1.21 \mathrm{E}-06$ & $<4.82 \mathrm{E}-04$ & 4.87E-04 \\
\hline $3-186948$ & 26 & $6.35 \mathrm{E}+02$ & $1.68 \mathrm{E}+01$ & $4.32 \mathrm{E}-03$ & $<1.2 \mathrm{E}+02$ & $<3.00 \mathrm{E}-02$ & $<1.21 \mathrm{E}-06$ & $<4.82 \mathrm{E}-04$ & 4.96E-04 \\
\hline
\end{tabular}


APPENDIX D3-1: LOADING CYCLE \#3

\section{Lead Column}

Resin: SuperLig ${ }^{\circledR} 639$

Resin Batch \# I-R2-03-27-02-20-45
Column size $=1.45 \mathrm{~cm}$

Flow rate $=3 \mathrm{BV} / \mathrm{h}(0.6 \mathrm{~mL} / \mathrm{min})$

BV - 12 mL

\begin{tabular}{|c|c|c|c|c|c|c|c|c|}
\hline LIMS \# & BV & $\begin{array}{l}\text { [Tc-99], } \\
\text { dpm/mL }\end{array}$ & $\begin{array}{l}{[\mathrm{Tc-99]},} \\
\mu \mathrm{Ci} / \mathrm{mL}\end{array}$ & [Tc-99], ug/L & [Tc-99],C/Co & {$[\mathbf{K}+], \mathbf{M}$} & {$[\mathbf{N a}+], \mathbf{M}$} & [NO3-], M \\
\hline $3-187298$ & 5 & $2.79 \mathrm{E}+03$ & $1.26 \mathrm{E}-03$ & $7.38 \mathrm{E}+01$ & $1.90 \mathrm{E}-02$ & $3.36 \mathrm{E}-01$ & $3.40 \mathrm{E}+00$ & $9.39 \mathrm{E}-01$ \\
\hline $3-187299$ & 10 & $4.70 \mathrm{E}+02$ & $2.12 \mathrm{E}-04$ & $1.24 \mathrm{E}+01$ & $3.20 \mathrm{E}-03$ & $\mathrm{~nm}$ & na & na \\
\hline $3-187300$ & 20 & $5.28 \mathrm{E}+02$ & $2.38 \mathrm{E}-04$ & $1.40 \mathrm{E}+01$ & $3.59 \mathrm{E}-03$ & $\mathrm{~nm}$ & na & $\mathrm{nm}$ \\
\hline $3-187301$ & 30 & $4.90 \mathrm{E}+02$ & $2.21 \mathrm{E}-04$ & $1.30 \mathrm{E}+01$ & $3.33 \mathrm{E}-03$ & $\mathrm{~nm}$ & na & na \\
\hline $3-187302$ & 40 & $4.42 \mathrm{E}+02$ & $1.99 \mathrm{E}-04$ & $1.17 \mathrm{E}+01$ & $3.01 \mathrm{E}-03$ & $\mathrm{~nm}$ & na & na \\
\hline $3-187303$ & 50 & $4.06 \mathrm{E}+02$ & $1.83 \mathrm{E}-04$ & $1.07 \mathrm{E}+01$ & $2.76 \mathrm{E}-03$ & 4.74E-01 & $4.65 \mathrm{E}+00$ & $1.17 \mathrm{E}+00$ \\
\hline $3-187304$ & 60 & $4.01 \mathrm{E}+02$ & $1.81 \mathrm{E}-04$ & $1.06 \mathrm{E}+01$ & $2.73 \mathrm{E}-03$ & $\mathrm{~nm}$ & na & na \\
\hline $3-187305$ & 70 & $5.51 \mathrm{E}+02$ & $2.48 \mathrm{E}-04$ & $1.46 \mathrm{E}+01$ & $3.75 \mathrm{E}-03$ & $\mathrm{~nm}$ & na & na \\
\hline $3-187306$ & 80 & $7.27 \mathrm{E}+02$ & $3.27 \mathrm{E}-04$ & $1.93 \mathrm{E}+01$ & $4.95 \mathrm{E}-03$ & $\mathrm{~nm}$ & na & na \\
\hline $3-187307$ & 90 & $9.45 \mathrm{E}+02$ & $4.26 \mathrm{E}-04$ & $2.50 \mathrm{E}+01$ & $6.43 \mathrm{E}-03$ & $\mathrm{~nm}$ & na & na \\
\hline $3-187308$ & 100 & $1.28 \mathrm{E}+03$ & $5.77 \mathrm{E}-04$ & $3.38 \mathrm{E}+01$ & $8.71 \mathrm{E}-03$ & 4.74E-01 & $4.61 \mathrm{E}+00$ & $1.30 \mathrm{E}+00$ \\
\hline 3-187309 & 110 & $1.55 \mathrm{E}+03$ & $6.98 \mathrm{E}-04$ & $4.10 \mathrm{E}+01$ & $1.05 \mathrm{E}-02$ & $\mathrm{~nm}$ & na & na \\
\hline $3-187310$ & 120 & $1.87 \mathrm{E}+03$ & $8.42 \mathrm{E}-04$ & $4.94 \mathrm{E}+01$ & $1.27 \mathrm{E}-02$ & $\mathrm{~nm}$ & na & na \\
\hline $3-187311$ & 130 & $2.53 \mathrm{E}+03$ & $1.14 \mathrm{E}-03$ & $6.71 \mathrm{E}+01$ & $1.72 \mathrm{E}-02$ & $\mathrm{~nm}$ & na & na \\
\hline $3-187312$ & 140 & $3.14 \mathrm{E}+03$ & $1.41 \mathrm{E}-03$ & $8.31 \mathrm{E}+01$ & $2.14 \mathrm{E}-02$ & $\mathrm{~V}$ & na & na \\
\hline $3-187313$ & 150 & $4.32 \mathrm{E}+03$ & $1.95 \mathrm{E}-03$ & $1.14 \mathrm{E}+02$ & $2.94 \mathrm{E}-02$ & $4.69 \mathrm{E}-01$ & $4.65 \mathrm{E}+00$ & $1.18 \mathrm{E}+00$ \\
\hline $3-187314$ & 160 & $3.78 \mathrm{E}+03$ & $1.70 \mathrm{E}-03$ & $1.00 \mathrm{E}+02$ & $2.57 \mathrm{E}-02$ & na & na & na \\
\hline $3-187315$ & 170 & $5.04 \mathrm{E}+03$ & $2.27 \mathrm{E}-03$ & $1.34 \mathrm{E}+02$ & $3.43 \mathrm{E}-02$ & na & na & na \\
\hline $3-187316$ & 180 & $5.92 \mathrm{E}+03$ & $2.67 \mathrm{E}-03$ & $1.57 \mathrm{E}+02$ & $4.03 \mathrm{E}-02$ & na & na & na \\
\hline $3-187317$ & 190 & $6.67 \mathrm{E}+03$ & $3.00 \mathrm{E}-03$ & $1.77 \mathrm{E}+02$ & $4.54 \mathrm{E}-02$ & na & na & na \\
\hline $3-187318$ & 200 & $7.62 \mathrm{E}+03$ & $3.43 \mathrm{E}-03$ & $2.02 \mathrm{E}+02$ & $5.18 \mathrm{E}-02$ & na & na & $1.11 \mathrm{E}+00$ \\
\hline $3-187319$ & 210 & $6.80 \mathrm{E}+03$ & $3.06 \mathrm{E}-03$ & $1.80 \mathrm{E}+02$ & $4.63 \mathrm{E}-02$ & na & na & na \\
\hline $3-187320$ & 220 & $7.35 \mathrm{E}+03$ & $3.31 \mathrm{E}-03$ & $1.95 \mathrm{E}+02$ & $5.00 \mathrm{E}-02$ & na & na & na \\
\hline 3-187321 & 230 & $1.02 \mathrm{E}+04$ & $4.59 \mathrm{E}-03$ & $2.69 \mathrm{E}+02$ & $6.94 \mathrm{E}-02$ & na & na & na \\
\hline $3-187322$ & 240 & $9.70 \mathrm{E}+03$ & $4.37 \mathrm{E}-03$ & $2.57 \mathrm{E}+02$ & $6.60 \mathrm{E}-02$ & na & na & na \\
\hline $3-187323$ & 250 & $1.41 \mathrm{E}+04$ & $6.35 \mathrm{E}-03$ & $3.75 \mathrm{E}+02$ & $9.59 \mathrm{E}-02$ & 4.74E-01 & $4.70 \mathrm{E}+00$ & $1.36 \mathrm{E}+00$ \\
\hline $3-187324$ & 260 & $1.38 \mathrm{E}+04$ & $6.22 \mathrm{E}-03$ & $3.64 \mathrm{E}+02$ & 9.39E-02 & na & na & na \\
\hline $3-187325$ & 270 & $1.64 \mathrm{E}+04$ & 7.39E-03 & $4.35 \mathrm{E}+02$ & $1.12 \mathrm{E}-01$ & na & na & na \\
\hline $3-187326$ & 280 & $2.14 \mathrm{E}+04$ & $9.64 \mathrm{E}-03$ & $5.66 \mathrm{E}+02$ & $1.46 \mathrm{E}-01$ & na & na & na \\
\hline $3-187327$ & 290 & $1.74 \mathrm{E}+04$ & $7.84 \mathrm{E}-03$ & $4.61 \mathrm{E}+02$ & $1.18 \mathrm{E}-01$ & na & na & na \\
\hline
\end{tabular}


APPENDIX D3-2: LOADING CYCLE \#3

Lag Column

Resin: SuperLig ${ }^{\circledR} 639$

Resin Batch \# I-R2-03-27-02-20-45
Column size $=1.45 \mathrm{~cm}$

Flow rate $=3 \mathrm{BV} / \mathrm{h}(0.6 \mathrm{~mL} / \mathrm{min})$

$\mathrm{BV}=12 \mathrm{~mL}$

Composite Fractions - Lag Column

\begin{tabular}{|c|c|c|c|c|}
\hline LIMS \# & Effluent fraction \# & [Tc-99], dpm/mL & [Tc-99], $\mu \mathrm{g} / \mathrm{L}$ & $\mathrm{C} / \mathrm{Co}$ \\
\hline $3-187366$ & bottle \# 1 - 20 BV & $5.99 \mathrm{E}+01$ & $1.59 \mathrm{E}+00$ & $4.07 \mathrm{E}-04$ \\
\hline $3-187367$ & bottle \# 2 - 20 BV & $6.49 \mathrm{E}+01$ & $1.72 \mathrm{E}+00$ & $4.41 \mathrm{E}-04$ \\
\hline $3-187368$ & bottle \# $3-\sim 20 \mathrm{BV}$ & $6.02 \mathrm{E}+01$ & $1.60 \mathrm{E}+00$ & $4.10 \mathrm{E}-04$ \\
\hline $3-187369$ & bottle \# 4 - 20 BV & $7.49 \mathrm{E}+01$ & $1.99 \mathrm{E}+00$ & $5.10 \mathrm{E}-04$ \\
\hline $3-187370$ & bottle \# 5 - 20 BV & $5.79 \mathrm{E}+01$ & $1.53 \mathrm{E}+00$ & $3.94 \mathrm{E}-04$ \\
\hline $3-187371$ & bottle \# $6-\sim 20 \mathrm{BV}$ & $2.64 \mathrm{E}+02$ & $6.99 \mathrm{E}+00$ & $1.80 \mathrm{E}-03$ \\
\hline $3-187372$ & bottle \# $7-\sim 20 \mathrm{BV}$ & $1.45 \mathrm{E}+02$ & $3.84 \mathrm{E}+00$ & $9.86 \mathrm{E}-04$ \\
\hline $3-187436$ & bottle \# $8-\sim 20 \mathrm{BV}$ & $1.77 \mathrm{E}+02$ & $4.69 \mathrm{E}+00$ & $1.20 \mathrm{E}-03$ \\
\hline
\end{tabular}

Individual Samples - Lag Column

\begin{tabular}{|c|c|c|c|c|}
\hline LIMS \# & BV & [Tc-99], dpm/mL & [Tc-99], $\mu \mathrm{g} / \mathrm{L}$ & $\mathrm{C} / \mathrm{Co}$ \\
\hline $3-187351$ & 20 & $5.26 \mathrm{E}+01$ & $1.39 \mathrm{E}+00$ & $3.58 \mathrm{E}-04$ \\
\hline $3-187352$ & 40 & $2.84 \mathrm{E}+01$ & $7.53 \mathrm{E}-01$ & $1.93 \mathrm{E}-04$ \\
\hline $3-187353$ & 60 & $4.59 \mathrm{E}+01$ & $1.22 \mathrm{E}+00$ & $3.12 \mathrm{E}-04$ \\
\hline $3-187354$ & 80 & $1.77 \mathrm{E}+02$ & $4.70 \mathrm{E}+00$ & $1.20 \mathrm{E}-03$ \\
\hline $3-187355$ & 100 & $4.10 \mathrm{E}+01$ & $1.09 \mathrm{E}+00$ & $2.79 \mathrm{E}-04$ \\
\hline $3-187356$ & 120 & $4.38 \mathrm{E}+01$ & $1.16 \mathrm{E}+00$ & $2.98 \mathrm{E}-04$ \\
\hline $3-187357$ & 140 & $9.04 \mathrm{E}+01$ & $2.40 \mathrm{E}+00$ & $6.15 \mathrm{E}-04$ \\
\hline $3-187358$ & 160 & $4.31 \mathrm{E}+01$ & $1.14 \mathrm{E}+00$ & $2.93 \mathrm{E}-04$ \\
\hline $3-187359$ & 180 & $6.74 \mathrm{E}+01$ & $1.79 \mathrm{E}+00$ & $4.59 \mathrm{E}-04$ \\
\hline $3-187360$ & 200 & $9.04 \mathrm{E}+01$ & $2.40 \mathrm{E}+00$ & $6.15 \mathrm{E}-04$ \\
\hline $3-187361$ & 220 & $5.91 \mathrm{E}+01$ & $1.57 \mathrm{E}+00$ & 0.000402 \\
\hline $3-187362$ & 240 & $6.97 \mathrm{E}+01$ & $1.85 \mathrm{E}+00$ & 0.0004741 \\
\hline $3-187363$ & 260 & $9.07 \mathrm{E}+01$ & $2.40 \mathrm{E}+00$ & 0.000617 \\
\hline
\end{tabular}


APPENDIX D3-3: LOADING CYCLE \#3

\section{Lag Column}

Resin: SuperLig ${ }^{\circledR} 639$

Column size $=1.45 \mathrm{~cm}$

Resin Batch \# I-R2-03-27-02-20-45

Flow rate $=3 \mathrm{BV} / \mathrm{h}(0.6 \mathrm{~mL} / \mathrm{min})$

$\mathrm{BV}=12 \mathrm{~mL}$

Feed Displacement $-0.1 \mathrm{NaOH}$

\begin{tabular}{|c|c|c|c|c|c|c|c|}
\hline Sample & LIMS \# & BV & [Tc-99], dpm/mL & [Tc-99],C/Co & {$\left[\mathrm{K}^{+}\right], \mathbf{M}$} & {$\left[\mathrm{Na}^{+}\right], \mathbf{M}$} & {$\left[\mathrm{NO3}^{-}\right], \mathrm{M}$} \\
\hline wash-1 & $3-187343$ & 0.50 & $1.91 \mathrm{E}+04$ & $1.30 \mathrm{E}-01$ & 4.49E-01 & $4.61 \mathrm{E}+00$ & $1.26 \mathrm{E}+00$ \\
\hline wash-2 & $3-187344$ & 1.00 & $1.74 \mathrm{E}+04$ & $1.18 \mathrm{E}-01$ & $1.89 \mathrm{E}-01$ & $2.24 \mathrm{E}+00$ & $6.26 \mathrm{E}-01$ \\
\hline wash-3 & $3-187345$ & 1.40 & $1.52 \mathrm{E}+04$ & $1.03 \mathrm{E}-01$ & $9.38 \mathrm{E}-02$ & 7.57E-01 & $2.47 \mathrm{E}-01$ \\
\hline wash-4 & $3-187346$ & 2.00 & $7.27 \mathrm{E}+03$ & $4.95 \mathrm{E}-02$ & $7.95 \mathrm{E}-02$ & $2.67 \mathrm{E}-01$ & $1.04 \mathrm{E}-01$ \\
\hline wash-5 & $3-187347$ & 2.50 & $6.03 \mathrm{E}+03$ & $4.10 \mathrm{E}-02$ & $5.85 \mathrm{E}-02$ & $1.65 \mathrm{E}-01$ & $6.40 \mathrm{E}-02$ \\
\hline wash-6 & $3-187348$ & 3.00 & $6.57 \mathrm{E}+03$ & 4.47E-02 & $3.85 \mathrm{E}-02$ & $1.38 \mathrm{E}-01$ & $3.58 \mathrm{E}-02$ \\
\hline wash-7 & $3-187349$ & 3.50 & $9.01 \mathrm{E}+03$ & $6.13 \mathrm{E}-02$ & $2.29 \mathrm{E}-02$ & $1.25 \mathrm{E}-01$ & $2.08 \mathrm{E}-02$ \\
\hline wash-8 & $3-187350$ & 4.00 & $1.34 \mathrm{E}+03$ & $9.12 \mathrm{E}-03$ & $1.33 \mathrm{E}-02$ & $1.17 \mathrm{E}-01$ & $1.12 \mathrm{E}-02$ \\
\hline
\end{tabular}




\section{APPENDIX D}

WSRC-TR-2003-00098, REVISION 0

SRT-RPP-2003-00026, REVISION 0

APPENDIX D3-4: LOADING CYCLE \#3

\section{Lead Column}

Eluant $=$ DI Water

Column size $=1.45 \mathrm{~cm}$

Eluant $=$ DI Water

Flow rate $=\sim 1 \mathrm{BV} / \mathrm{h}(\sim 0.2 \mathrm{~mL} / \mathrm{min}) \mathrm{BV}=12 \mathrm{~mL}$

Resin Batch \# I-R2-03-27-02-20-45 Temperature $=65^{\circ} \mathrm{C}$

\begin{tabular}{|c|c|c|c|c|c|c|c|c|c|c|}
\hline LIMS \# & BV & $\begin{array}{l}\text { [Tc-99], } \\
\text { dpm/mL }\end{array}$ & $\begin{array}{c}{[\mathrm{Tc}-99]} \\
\mu \mathrm{g} / \mathrm{L}\end{array}$ & $\begin{array}{c}\text { [Tc-99], } \\
\text { C/Co }\end{array}$ & $\begin{array}{c}\text { [Tc-99], } \\
\mu \mathrm{g} / \mathrm{L}\end{array}$ & $\begin{array}{c}\text { [Tc-99], } \\
\text { C/Co }\end{array}$ & [Tc-99], M & {$\left[\mathbf{K}^{+}\right], \mathbf{M}$} & {$\left[\mathrm{Na}^{+}\right], \mathbf{M}$} & {$\left[\mathrm{NO3}^{-}\right], \mathrm{M}$} \\
\hline 300187374 & 0.5 & $\mathrm{~nm}$ & $\mathrm{~nm}$ & $\mathrm{~nm}$ & $2.51 \mathrm{E}+04$ & $6.27 \mathrm{E}+00$ & $2.54 \mathrm{E}-04$ & $9.72 \mathrm{E}-03$ & $9.83 \mathrm{E}-02$ & $4.56 \mathrm{E}-03$ \\
\hline 300187375 & 1 & $\mathrm{~nm}$ & $\mathrm{~nm}$ & $\mathrm{~nm}$ & $2.07 \mathrm{E}+04$ & $5.17 \mathrm{E}+00$ & $2.09 \mathrm{E}-04$ & $1.02 \mathrm{E}-02$ & $1.03 \mathrm{E}-01$ & $5.02 \mathrm{E}-03$ \\
\hline 300187376 & 1.5 & $\mathrm{~nm}$ & $\mathrm{~nm}$ & $\mathrm{~nm}$ & $7.05 \mathrm{E}+04$ & $1.76 \mathrm{E}+01$ & $7.12 \mathrm{E}-04$ & $5.23 \mathrm{E}-03$ & $3.17 \mathrm{E}-02$ & $1.47 \mathrm{E}-03$ \\
\hline 300187377 & 2 & $\mathrm{~nm}$ & $\mathrm{~nm}$ & $\mathrm{~nm}$ & $2.79 \mathrm{E}+05$ & $6.96 \mathrm{E}+01$ & $2.81 \mathrm{E}-03$ & $3.08 \mathrm{E}-03$ & $1.14 \mathrm{E}-02$ & 8.39E-04 \\
\hline 300187378 & 2.5 & $\mathrm{~nm}$ & $\mathrm{~nm}$ & $\mathrm{~nm}$ & $4.01 \mathrm{E}+05$ & $1.00 \mathrm{E}+02$ & $4.05 \mathrm{E}-03$ & $2.21 \mathrm{E}-03$ & $6.83 \mathrm{E}-03$ & $6.13 \mathrm{E}-04$ \\
\hline 300187379 & 3 & $\mathrm{~nm}$ & $\mathrm{~nm}$ & $\mathrm{~nm}$ & $3.00 \mathrm{E}+05$ & $7.50 \mathrm{E}+01$ & $3.03 \mathrm{E}-03$ & $2.74 \mathrm{E}-03$ & $4.16 \mathrm{E}-03$ & $4.84 \mathrm{E}-04$ \\
\hline 300187437 & 3.5 & $\mathrm{~nm}$ & $\mathrm{~nm}$ & $\mathrm{~nm}$ & $2.58 \mathrm{E}+05$ & $6.45 \mathrm{E}+01$ & 0.00260606 & $3.36 \mathrm{E}-03$ & $2.48 \mathrm{E}-03$ & $\mathrm{~nm}$ \\
\hline 300187380 & 4 & $\mathrm{~nm}$ & $\mathrm{~nm}$ & $\mathrm{~nm}$ & $2.57 \mathrm{E}+05$ & $6.41 \mathrm{E}+01$ & $2.59 \mathrm{E}-03$ & $3.36 \mathrm{E}-03$ & $2.10 \mathrm{E}-03$ & $4.35 \mathrm{E}-04$ \\
\hline 300187381 & 6 & $\mathrm{~nm}$ & $\mathrm{~nm}$ & $\mathrm{~nm}$ & $1.01 \mathrm{E}+05$ & $2.51 \mathrm{E}+01$ & $1.02 \mathrm{E}-03$ & $2.79 \mathrm{E}-03$ & $2.99 \mathrm{E}-03$ & $\mathrm{~nm}$ \\
\hline 300187382 & 8 & $\mathrm{~nm}$ & $\mathrm{~nm}$ & $\mathrm{~nm}$ & $4.99 \mathrm{E}+03$ & $1.25 \mathrm{E}+00$ & $5.04 \mathrm{E}-05$ & $1.91 \mathrm{E}-03$ & $5.83 \mathrm{E}-03$ & $\mathrm{~nm}$ \\
\hline 300187383 & 10 & $8.03 E+03$ & $\mathrm{~nm}$ & $5.46 \mathrm{E}-02$ & $2.10 \mathrm{E}+02$ & $5.25 \mathrm{E}-02$ & $2.12 \mathrm{E}-06$ & $<4.82 \mathrm{E}-04$ & $1.67 \mathrm{E}-03$ & $\mathrm{~nm}$ \\
\hline 300187384 & 12 & $\mathrm{~nm}$ & $\mathrm{~nm}$ & $\mathrm{v}$ & $1.02 \mathrm{E}+02$ & $2.55 \mathrm{E}-02$ & $1.03 \mathrm{E}-06$ & $<4.82 \mathrm{E}-04$ & $1.34 \mathrm{E}-03$ & $\mathrm{~nm}$ \\
\hline 300187385 & 14 & $\mathrm{~nm}$ & $\mathrm{~nm}$ & $\mathrm{~nm}$ & $6.70 \mathrm{E}+01$ & $1.67 \mathrm{E}-02$ & $6.7677 \mathrm{E}-07$ & $<4.82 \mathrm{E}-04$ & $1.36 \mathrm{E}-03$ & $\mathrm{~nm}$ \\
\hline 300187386 & 16 & $\mathrm{~nm}$ & $\mathrm{v}$ & $\mathrm{nm}$ & $<1.2 \mathrm{E}+02$ & $<3.00 \mathrm{E}-02$ & $<1.21 \mathrm{E}-06$ & $<4.82 \mathrm{E}-04$ & $1.19 \mathrm{E}-03$ & $\mathrm{~nm}$ \\
\hline 300187387 & 18 & $\mathrm{~nm}$ & $\mathrm{~nm}$ & $\mathrm{~nm}$ & $<1.2 \mathrm{E}+02$ & $<3.00 \mathrm{E}-02$ & $<1.21 \mathrm{E}-06$ & $<4.82 \mathrm{E}-04$ & $1.07 \mathrm{E}-03$ & $\mathrm{~nm}$ \\
\hline 300187388 & 20 & $9.58 \mathrm{E}+02$ & $\mathrm{~nm}$ & $6.52 \mathrm{E}-03$ & $<1.2 \mathrm{E}+02$ & $<3.00 \mathrm{E}-02$ & $<1.21 \mathrm{E}-06$ & $<4.82 \mathrm{E}-04$ & $9.70 \mathrm{E}-04$ & $\mathrm{~nm}$ \\
\hline 300187389 & 22 & $8.15 E+02$ & $\mathrm{~nm}$ & $5.54 \mathrm{E}-03$ & $<1.2 \mathrm{E}+02$ & $<3.00 \mathrm{E}-02$ & $<1.21 \mathrm{E}-06$ & $<4.82 \mathrm{E}-04$ & $9.09 \mathrm{E}-04$ & $\mathrm{~nm}$ \\
\hline 300187390 & 24 & $\mathrm{~nm}$ & $\mathrm{~nm}$ & $\mathrm{~nm}$ & $<1.2 \mathrm{E}+02$ & $<3.00 \mathrm{E}-02$ & $<1.21 \mathrm{E}-06$ & $5.62 \mathrm{E}-04$ & $2.11 \mathrm{E}-03$ & $\mathrm{~nm}$ \\
\hline 300187391 & 26 & $5.56 \mathrm{E}+02$ & $\mathrm{~nm}$ & $3.78 \mathrm{E}-03$ & $<1.2 \mathrm{E}+02$ & $<3.00 \mathrm{E}-02$ & $<1.21 \mathrm{E}-06$ & $<4.82 \mathrm{E}-04$ & $1.08 \mathrm{E}-03$ & $\mathrm{~nm}$ \\
\hline
\end{tabular}


APPENDIX D4-1: LOADING CYCLE \#4

\section{Lead Column}

Resin: SuperLig ${ }^{\circledR} 639$

Resin Batch \# I-R2-03-27-02-20-45
Column size $=1.45 \mathrm{~cm}$

Flow rate $=3 \mathrm{BV} / \mathrm{h}(0.6 \mathrm{~mL} / \mathrm{min})$

$\mathrm{BV}=12 \mathrm{~mL}$

\begin{tabular}{|c|c|c|c|c|c|c|c|c|}
\hline LIMS \# & BV & $\begin{array}{l}\text { [Tc-99], } \\
\text { dpm/mL }\end{array}$ & $\begin{array}{l}{[\text { Tc-99], }} \\
\mu \mathrm{Ci} / \mathbf{m L}\end{array}$ & {$[\mathrm{Tc-99]}, \mu \mathrm{g} / \mathrm{L}$} & [Tc-99],C/Co & [Tc-99], M & {$[\mathbf{K}+], \mathbf{M}$} & {$[\mathbf{N a}+], \mathbf{M}$} \\
\hline $3-188442$ & 5 & $2.72 \mathrm{E}+02$ & $1.23 \mathrm{E}-04$ & & $1.85 \mathrm{E}-03$ & $\mathrm{~nm}$ & $\mathrm{~nm}$ & $\mathrm{~nm}$ \\
\hline $3-187912$ & 10 & $3.04 \mathrm{E}+02$ & $1.37 \mathrm{E}-04$ & $8.06 \mathrm{E}+00$ & $2.07 \mathrm{E}-03$ & $<6.00 \mathrm{E}-07$ & 0.45 & 5.13 \\
\hline $3-187913$ & 20 & $3.29 \mathrm{E}+02$ & $1.48 \mathrm{E}-04$ & $8.73 \mathrm{E}+00$ & $2.24 \mathrm{E}-03$ & $\mathrm{~nm}$ & $\mathrm{~nm}$ & $\mathrm{~nm}$ \\
\hline $3-187914$ & 30 & $3.51 \mathrm{E}+02$ & $1.58 \mathrm{E}-04$ & $9.29 \mathrm{E}+00$ & $2.39 \mathrm{E}-03$ & $\mathrm{~nm}$ & $\mathrm{~nm}$ & $\mathrm{~nm}$ \\
\hline $3-187915$ & 40 & $3.26 \mathrm{E}+02$ & $1.47 \mathrm{E}-04$ & $8.64 \mathrm{E}+00$ & $2.22 \mathrm{E}-03$ & $\mathrm{~nm}$ & $\mathrm{~nm}$ & $\mathrm{~nm}$ \\
\hline $3-187916$ & 50 & $2.45 \mathrm{E}+02$ & $1.10 \mathrm{E}-04$ & $6.50 \mathrm{E}+00$ & $1.67 \mathrm{E}-03$ & $<6.00 \mathrm{E}-07$ & 0.47 & 5.30 \\
\hline $3-187917$ & 60 & $4.92 \mathrm{E}+02$ & $2.22 \mathrm{E}-04$ & $1.30 \mathrm{E}+01$ & $3.35 \mathrm{E}-03$ & $\mathrm{~nm}$ & $\mathrm{~nm}$ & $\mathrm{~nm}$ \\
\hline $3-187918$ & 70 & $6.27 \mathrm{E}+02$ & $2.82 \mathrm{E}-04$ & $1.66 \mathrm{E}+01$ & $4.27 \mathrm{E}-03$ & $\mathrm{~nm}$ & $\mathrm{~nm}$ & $\mathrm{~nm}$ \\
\hline $3-187919$ & 80 & $7.19 \mathrm{E}+02$ & $3.24 \mathrm{E}-04$ & $1.90 \mathrm{E}+01$ & 4.89E-03 & $\mathrm{nm}$ & $\mathrm{nm}$ & $\mathrm{nm}$ \\
\hline $3-187920$ & 90 & $1.05 \mathrm{E}+03$ & 4.73E-04 & $2.78 \mathrm{E}+01$ & $7.14 \mathrm{E}-03$ & $\mathrm{~nm}$ & $\mathrm{~nm}$ & $\mathrm{~nm}$ \\
\hline $3-187921$ & 100 & $1.22 \mathrm{E}+03$ & $5.50 \mathrm{E}-04$ & $3.23 \mathrm{E}+01$ & $8.30 \mathrm{E}-03$ & $<6.00 \mathrm{E}-07$ & 0.48 & 5.43 \\
\hline $3-187922$ & 110 & $1.96 \mathrm{E}+03$ & 8.83E-04 & $5.19 \mathrm{E}+01$ & $1.33 \mathrm{E}-02$ & $\mathrm{~nm}$ & $\mathrm{~nm}$ & NA \\
\hline $3-187923$ & 120 & $1.89 \mathrm{E}+03$ & $8.51 \mathrm{E}-04$ & $5.01 \mathrm{E}+01$ & $1.29 \mathrm{E}-02$ & $\mathrm{~nm}$ & $\mathrm{~nm}$ & NA \\
\hline $3-187924$ & 130 & $3.03 \mathrm{E}+03$ & $1.36 \mathrm{E}-03$ & $8.02 \mathrm{E}+01$ & $2.06 \mathrm{E}-02$ & $\mathrm{~nm}$ & $\mathrm{~nm}$ & NA \\
\hline $3-187925$ & 140 & $3.30 \mathrm{E}+03$ & $1.49 \mathrm{E}-03$ & $8.76 \mathrm{E}+01$ & $2.24 \mathrm{E}-02$ & $\mathrm{~nm}$ & $\mathrm{~nm}$ & NA \\
\hline $3-187926$ & 150 & $4.29 \mathrm{E}+03$ & $1.93 \mathrm{E}-03$ & $1.14 \mathrm{E}+02$ & $2.92 \mathrm{E}-02$ & $8.18182 \mathrm{E}-07$ & 0.48 & 5.35 \\
\hline $3-187927$ & 160 & $5.60 \mathrm{E}+03$ & $2.52 \mathrm{E}-03$ & $1.48 \mathrm{E}+02$ & $3.81 \mathrm{E}-02$ & $8.0303 \mathrm{E}-07$ & 0.47 & 5.35 \\
\hline $3-187928$ & 170 & $6.12 \mathrm{E}+03$ & $2.76 \mathrm{E}-03$ & $1.62 \mathrm{E}+02$ & $4.16 \mathrm{E}-02$ & $\mathrm{~nm}$ & $\mathrm{~nm}$ & $\mathrm{~nm}$ \\
\hline $3-187929$ & 180 & $6.16 \mathrm{E}+03$ & $2.77 \mathrm{E}-03$ & $1.63 \mathrm{E}+02$ & $4.19 \mathrm{E}-02$ & $\mathrm{~nm}$ & $\mathrm{~nm}$ & $\mathrm{~nm}$ \\
\hline $3-187930$ & 190 & $7.66 \mathrm{E}+03$ & $3.45 \mathrm{E}-03$ & $2.03 \mathrm{E}+02$ & $5.21 \mathrm{E}-02$ & $\mathrm{~nm}$ & $\mathrm{~nm}$ & $\mathrm{~nm}$ \\
\hline $3-187931$ & 200 & $8.36 \mathrm{E}+03$ & $3.77 \mathrm{E}-03$ & $2.22 \mathrm{E}+02$ & $5.69 \mathrm{E}-02$ & $\mathrm{~nm}$ & $\mathrm{~nm}$ & $\mathrm{~nm}$ \\
\hline $3-187932$ & 210 & $9.67 \mathrm{E}+03$ & $4.36 \mathrm{E}-03$ & $2.56 \mathrm{E}+02$ & $6.58 \mathrm{E}-02$ & $2.13131 \mathrm{E}-06$ & 0.47 & 5.39 \\
\hline $3-187933$ & 220 & $1.10 \mathrm{E}+04$ & $4.95 \mathrm{E}-03$ & $2.93 \mathrm{E}+02$ & $7.48 \mathrm{E}-02$ & $\mathrm{~nm}$ & $\mathrm{~nm}$ & $\mathrm{~nm}$ \\
\hline $3-187934$ & 230 & $1.22 \mathrm{E}+04$ & $5.50 \mathrm{E}-03$ & $3.23 \mathrm{E}+02$ & $8.30 \mathrm{E}-02$ & $\mathrm{~nm}$ & $\mathrm{~nm}$ & $\mathrm{~nm}$ \\
\hline $3-187935$ & 240 & $1.32 \mathrm{E}+04$ & $5.95 \mathrm{E}-03$ & $3.50 \mathrm{E}+02$ & 8.98E-02 & $\mathrm{nm}$ & $\mathrm{nm}$ & $\mathrm{nm}$ \\
\hline $3-187936$ & 250 & $1.41 \mathrm{E}+04$ & $6.35 \mathrm{E}-03$ & $3.73 \mathrm{E}+02$ & $9.59 \mathrm{E}-02$ & $\mathrm{~nm}$ & $\mathrm{~nm}$ & $\mathrm{~nm}$ \\
\hline $3-187937$ & 260 & $1.54 \mathrm{E}+04$ & $6.94 \mathrm{E}-03$ & $4.09 \mathrm{E}+02$ & $1.05 \mathrm{E}-01$ & $3.02525 \mathrm{E}-06$ & 0.57 & 5.17 \\
\hline $3-187938$ & 270 & $1.80 \mathrm{E}+04$ & $8.11 \mathrm{E}-03$ & $4.76 \mathrm{E}+02$ & $1.22 \mathrm{E}-01$ & $\mathrm{~nm}$ & $\mathrm{~nm}$ & $\mathrm{~nm}$ \\
\hline $3-187939$ & 280 & $1.94 \mathrm{E}+04$ & $8.74 \mathrm{E}-03$ & $5.15 \mathrm{E}+02$ & $1.32 \mathrm{E}-01$ & $\mathrm{~nm}$ & $\mathrm{~nm}$ & $\mathrm{~nm}$ \\
\hline $3-187940$ & 290 & $2.04 \mathrm{E}+04$ & $9.19 \mathrm{E}-03$ & $5.42 \mathrm{E}+02$ & $1.39 \mathrm{E}-01$ & $\mathrm{~nm}$ & $\mathrm{~nm}$ & $\mathrm{~nm}$ \\
\hline
\end{tabular}


APPENDIX D4-2: LOADING CYCLE \#4

Lag Column

Resin: SuperLig ${ }^{\circledR} 639$

Resin Batch \# I-R2-03-27-02-20-45
Column size $=1.45 \mathrm{~cm}$

Flow rate $=3 \mathrm{BV} / \mathrm{h}(0.6 \mathrm{~mL} / \mathrm{min})$

$\mathrm{BV}=12 \mathrm{~mL}$

Composite Fractions - Lag Column

\begin{tabular}{|c|c|c|c|c|}
\hline LIMS \# & Effluent fraction \# & [Tc-99], dpm/mL & [Tc-99], $\mu \mathrm{g} / \mathrm{L}$ & $\mathrm{C} / \mathrm{Co}$ \\
\hline $3-187965$ & bottle \# 1- 20 BV & $6.23 \mathrm{E}+01$ & $1.65 \mathrm{E}+00$ & $4.24 \mathrm{E}-04$ \\
\hline $3-187966$ & bottle \# $2-\sim 20$ BV & $8.97 \mathrm{E}+01$ & $2.38 \mathrm{E}+00$ & $6.10 \mathrm{E}-04$ \\
\hline $3-187967$ & bottle \# $3-\sim 20 \mathrm{BV}$ & $8.74 \mathrm{E}+01$ & $2.32 \mathrm{E}+00$ & $5.95 \mathrm{E}-04$ \\
\hline 3-187968 & bottle \# $4-\sim 20 \mathrm{BV}$ & $6.03 \mathrm{E}+01$ & $1.60 \mathrm{E}+00$ & $4.10 \mathrm{E}-04$ \\
\hline $3-187969$ & bottle \# 5- 20 BV & $8.57 \mathrm{E}+01$ & $2.27 \mathrm{E}+00$ & $5.83 \mathrm{E}-04$ \\
\hline $3-187970$ & bottle \# 6 - 20 BV & $6.44 \mathrm{E}+01$ & $1.71 \mathrm{E}+00$ & $4.38 \mathrm{E}-04$ \\
\hline $3-187971$ & bottle \# 7 - 20 BV & $8.75 \mathrm{E}+01$ & $2.32 \mathrm{E}+00$ & $5.95 \mathrm{E}-04$ \\
\hline 3-187972 & bottle \# $8-\sim 20 \mathrm{BV}$ & $1.38 \mathrm{E}+02$ & $3.64 \mathrm{E}+00$ & $9.39 \mathrm{E}-04$ \\
\hline $3-187973$ & bottle \# 9 - 20 BV & $\mathrm{nm}$ & $\mathrm{nm}$ & $\mathrm{nm}$ \\
\hline $3-187974$ & bottle \# $10-\sim 20 \mathrm{BV}$ & $\mathrm{nm}$ & $\mathrm{nm}$ & $\mathrm{nm}$ \\
\hline $3-187975$ & bottle \# 11 - 20 BV & $\mathrm{nm}$ & $\mathrm{nm}$ & $\mathrm{nm}$ \\
\hline $3-187976$ & bottle \# 12 - 20 BV & $\mathrm{nm}$ & $\mathrm{nm}$ & $\mathrm{nm}$ \\
\hline
\end{tabular}

Individual Samples - Lag Column

\begin{tabular}{|c|c|c|c|c|}
\hline LIMS \# & BV & [Tc-99], dpm/mL & [Tc-99], $\mu \mathrm{g} / \mathrm{L}$ & $\mathrm{C} / \mathrm{Co}$ \\
\hline $3-187950$ & 20 & $8.22 \mathrm{E}+01$ & $2.18 \mathrm{E}+00$ & 5.59E-04 \\
\hline $3-187951$ & 40 & $9.95 \mathrm{E}+01$ & $2.64 \mathrm{E}+00$ & $6.77 \mathrm{E}-04$ \\
\hline $3-187952$ & 60 & $8.37 \mathrm{E}+01$ & $2.22 \mathrm{E}+00$ & 5.69E-04 \\
\hline $3-187953$ & 80 & $9.18 \mathrm{E}+01$ & $2.43 \mathrm{E}+00$ & $6.24 \mathrm{E}-04$ \\
\hline $3-187954$ & 100 & $8.26 \mathrm{E}+01$ & $2.19 \mathrm{E}+00$ & $5.62 \mathrm{E}-04$ \\
\hline $3-187955$ & 120 & $8.03 \mathrm{E}+01$ & $2.13 \mathrm{E}+00$ & $5.46 \mathrm{E}-04$ \\
\hline $3-187956$ & 140 & $8.46 \mathrm{E}+01$ & $2.24 \mathrm{E}+00$ & $5.76 \mathrm{E}-04$ \\
\hline $3-187957$ & 160 & $1.04 \mathrm{E}+02$ & $2.75 \mathrm{E}+00$ & 7.07E-04 \\
\hline $3-187958$ & 180 & $8.70 \mathrm{E}+01$ & $2.31 \mathrm{E}+00$ & 5.92E-04 \\
\hline $3-187959$ & 200 & $9.29 \mathrm{E}+01$ & $2.46 \mathrm{E}+00$ & $6.32 \mathrm{E}-04$ \\
\hline $3-187960$ & 220 & $1.24 \mathrm{E}+02$ & $3.28 \mathrm{E}+00$ & $8.44 \mathrm{E}-04$ \\
\hline $3-187961$ & 240 & $8.07 \mathrm{E}+01$ & $2.14 \mathrm{E}+00$ & 5.49E-04 \\
\hline $3-187962$ & 260 & $1.23 \mathrm{E}+02$ & $3.25 \mathrm{E}+00$ & $8.37 \mathrm{E}-04$ \\
\hline $3-187963$ & 280 & $1.57 \mathrm{E}+02$ & $4.16 \mathrm{E}+00$ & $1.07 \mathrm{E}-03$ \\
\hline
\end{tabular}

$\mathrm{nm}=$ not measured 
APPENDIX D4-3: LOADING CYCLE \#4

\section{Lag Column}

Resin: SuperLig ${ }^{\circledR} 639$

Resin Batch \# I-R2-03-27-02-20-45
Column size $=1.45 \mathrm{~cm}$

Flow rate $=3 \mathrm{BV} / \mathrm{h}(0.6 \mathrm{~mL} / \mathrm{min})$

$\mathrm{BV}=12 \mathrm{~mL}$

Feed Displacement $-0.1 \mathrm{NaOH}$

\begin{tabular}{|c|c|c|c|c|c|c|c|}
\hline Sample & LIMS \# & BV & [Tc-99], dpm/mL & [Tc-99], M & {$\left[\mathrm{K}^{+}\right], \mathbf{M}$} & {$\left[\mathrm{Na}^{+}\right], \mathrm{M}$} & {$\left[\mathrm{NO3}^{-}\right], \mathrm{M}$} \\
\hline wash-1 & 3-186942 & 0.5 & $4.44 \mathrm{E}+02$ & $4.48 \mathrm{E}-06$ & $5.69 \mathrm{E}-01$ & $5.09 \mathrm{E}+00$ & $1.12 \mathrm{E}+00$ \\
\hline wash-2 & $3-186943$ & 1 & $5.37 \mathrm{E}+02$ & $5.42 \mathrm{E}-06$ & $2.87 \mathrm{E}-01$ & $2.92 \mathrm{E}+00$ & 7.34E-01 \\
\hline wash-3 & 3-186944 & 1.5 & $3.90 \mathrm{E}+02$ & $3.94 \mathrm{E}-06$ & $1.02 \mathrm{E}-01$ & $9.09 \mathrm{E}-01$ & 3.82E-01 \\
\hline wash-4 & $3-186945$ & 2 & $\mathrm{~nm}$ & $\mathrm{~nm}$ & $7.90 \mathrm{E}-02$ & $3.51 \mathrm{E}-01$ & $1.71 \mathrm{E}-01$ \\
\hline wash-5 & $3-186946$ & 2.5 & $\mathrm{~nm}$ & $\mathrm{~nm}$ & $6.21 \mathrm{E}-02$ & $2.00 \mathrm{E}-01$ & $8.05 \mathrm{E}-02$ \\
\hline wash-6 & $3-186947$ & 3 & $\mathrm{~nm}$ & $\mathrm{~nm}$ & $3.33 \mathrm{E}-02$ & $1.50 \mathrm{E}-01$ & 4.71E-02 \\
\hline wash-7 & 3-186948 & 3.5 & $\mathrm{~nm}$ & $\mathrm{~nm}$ & $2.23 \mathrm{E}-02$ & $1.37 \mathrm{E}-01$ & $3.37 \mathrm{E}-02$ \\
\hline wash-8 & 3-186949 & 4 & $\mathrm{~nm}$ & $\mathrm{~nm}$ & $1.43 \mathrm{E}-02$ & $1.26 \mathrm{E}-01$ & $2.27 \mathrm{E}-02$ \\
\hline
\end{tabular}




\section{APPENDIX D}

WSRC-TR-2003-00098, REVISION 0 SRT-RPP-2003-00026, REVISION 0

APPENDIX D4-4: LOADING CYCLE \#4

\section{Lead Column}

Eluant $=$ DI Water

Resin Batch \# I-R2-03-27-02-20-45

Column size $=1.45 \mathrm{~cm}$

Flow rate $=\sim 1 \mathrm{BV} / \mathrm{h}(\sim 0.2 \mathrm{~mL} / \mathrm{min}) ; \mathrm{BV}=12 \mathrm{~mL}$

Temperature $=65^{\circ} \mathrm{C}$

\begin{tabular}{|c|c|c|c|c|c|c|c|c|c|c|}
\hline LIMS \# & BV & $\begin{array}{l}\text { [Tc-99], } \\
\mathrm{dpm} / \mathrm{mL}\end{array}$ & $\begin{array}{c}\text { [Tc-99], } \\
\mu \mathrm{g} / \mathrm{L}\end{array}$ & $\begin{array}{c}\text { [Tc-99], } \\
\text { C/Co }\end{array}$ & $\begin{array}{c}\text { [Tc-99], } \\
\mu \mathrm{g} / \mathrm{L}\end{array}$ & $\begin{array}{c}\text { [Tc-99], } \\
\text { C/Co }\end{array}$ & [Tc-99], M & {$\left[\mathrm{K}^{+}\right], \mathbf{M}$} & {$\left[\mathrm{Na}^{+}\right], \mathrm{M}$} & {$\left[\mathrm{NO3}^{-}\right], \mathrm{M}$} \\
\hline $3-187977$ & 0.5 & $\mathrm{~nm}$ & $\mathrm{~nm}$ & na & $1.41 \mathrm{E}+04$ & $3.51 \mathrm{E}+00$ & $1.42 \mathrm{E}-04$ & $1.60 \mathrm{E}-02$ & $1.29 \mathrm{E}-01$ & $3-187977$ \\
\hline 3-187978 & 1 & $\mathrm{~nm}$ & $\mathrm{~nm}$ & na & $2.97 \mathrm{E}+04$ & $7.41 \mathrm{E}+00$ & $2.99 \mathrm{E}-04$ & $1.17 \mathrm{E}-02$ & $1.08 \mathrm{E}-01$ & $3-187978$ \\
\hline 3-187979 & 1.5 & $\mathrm{~nm}$ & $\mathrm{~nm}$ & na & $5.92 \mathrm{E}+04$ & $1.48 \mathrm{E}+01$ & $5.98 \mathrm{E}-04$ & $6.72 \mathrm{E}-03$ & $4.26 \mathrm{E}-02$ & $3-187979$ \\
\hline 3-187980 & 2 & $\mathrm{~nm}$ & $\mathrm{~nm}$ & na & $2.67 \mathrm{E}+05$ & $6.67 \mathrm{E}+01$ & $2.70 \mathrm{E}-03$ & $3.72 \mathrm{E}-03$ & $1.32 \mathrm{E}-02$ & $3-187980$ \\
\hline 3-187981 & 2.5 & $\mathrm{~nm}$ & $\mathrm{~nm}$ & na & $5.14 \mathrm{E}+05$ & $1.28 \mathrm{E}+02$ & $5.19 \mathrm{E}-03$ & $2.09 \mathrm{E}-03$ & $7.57 \mathrm{E}-03$ & $3-187981$ \\
\hline 3-187982 & 3 & $\mathrm{~nm}$ & $\mathrm{~nm}$ & na & $3.46 \mathrm{E}+05$ & $8.63 \mathrm{E}+01$ & $3.49 \mathrm{E}-03$ & $2.50 \mathrm{E}-03$ & $3.97 \mathrm{E}-03$ & $3-187982$ \\
\hline 3-187983 & 3.5 & $\mathrm{~nm}$ & $\mathrm{~nm}$ & na & $2.79 \mathrm{E}+05$ & $6.97 \mathrm{E}+01$ & $2.82 \mathrm{E}-03$ & $3.08 \mathrm{E}-03$ & $2.21 \mathrm{E}-03$ & $3-187983$ \\
\hline 3-187984 & 4 & $\mathrm{~nm}$ & $\mathrm{~nm}$ & na & $2.62 \mathrm{E}+05$ & $6.55 \mathrm{E}+01$ & $2.65 \mathrm{E}-03$ & $3.31 \mathrm{E}-03$ & $1.36 \mathrm{E}-03$ & $3-187984$ \\
\hline 3-187985 & 6 & $\mathrm{~nm}$ & $\mathrm{~nm}$ & na & $8.50 \mathrm{E}+04$ & $2.12 \mathrm{E}+01$ & $8.58 \mathrm{E}-04$ & $1.64 \mathrm{E}-03$ & $1.03 \mathrm{E}-03$ & $3-187985$ \\
\hline 3-187986 & 8 & $\mathrm{~nm}$ & $\mathrm{~nm}$ & na & $2.64 \mathrm{E}+03$ & $6.60 \mathrm{E}-01$ & $2.67 \mathrm{E}-05$ & $6.28 \mathrm{E}-04$ & $8.78 \mathrm{E}-04$ & 3-187986 \\
\hline $3-187987$ & 10 & $\mathrm{~nm}$ & $\mathrm{~nm}$ & na & $2.09 \mathrm{E}+02$ & $5.22 \mathrm{E}-02$ & $2.11 \mathrm{E}-06$ & $4.23 \mathrm{E}-04$ & $7.83 \mathrm{E}-04$ & $3-187987$ \\
\hline $3-187988$ & 12 & $\mathrm{~nm}$ & $\mathrm{~nm}$ & na & $<6.0 \mathrm{E}+01$ & $<1.50 \mathrm{E}-02$ & $<6.00 \mathrm{E}-07$ & $2.95 \mathrm{E}-04$ & $6.87 \mathrm{E}-04$ & 3-187988 \\
\hline 3-187989 & 14 & $1.65 \mathrm{E}+03$ & $4.38 \mathrm{E}+01$ & $1.12 \mathrm{E}-02$ & $<6.0 \mathrm{E}+01$ & $<1.50 \mathrm{E}-02$ & $<6.00 \mathrm{E}-07$ & $2.79 \mathrm{E}-04$ & $5.35 \mathrm{E}-04$ & 3-187989 \\
\hline 3-187990 & 16 & $1.14 \mathrm{E}+03$ & $3.02 \mathrm{E}+01$ & $7.76 \mathrm{E}-03$ & $<6.0 \mathrm{E}+01$ & $<1.50 \mathrm{E}-02$ & $<6.00 \mathrm{E}-07$ & $<2.56 \mathrm{E}-05$ & 4.91E-04 & $3-187990$ \\
\hline 3-187991 & 18 & $9.14 \mathrm{E}+02$ & $2.42 \mathrm{E}+01$ & $6.22 \mathrm{E}-03$ & $<6.0 \mathrm{E}+01$ & $<1.50 \mathrm{E}-02$ & $<6.00 \mathrm{E}-07$ & $<2.56 \mathrm{E}-05$ & $5.83 \mathrm{E}-04$ & 3-187991 \\
\hline 3-187992 & 20 & $7.78 \mathrm{E}+02$ & $2.06 \mathrm{E}+01$ & $5.29 \mathrm{E}-03$ & $<6.0 \mathrm{E}+01$ & $<1.50 \mathrm{E}-02$ & $<6.00 \mathrm{E}-07$ & $<2.56 \mathrm{E}-05$ & $3.99 \mathrm{E}-04$ & $3-187992$ \\
\hline $3-187993$ & 22 & $6.83 \mathrm{E}+02$ & $1.81 \mathrm{E}+01$ & $4.65 \mathrm{E}-03$ & $<6.0 \mathrm{E}+01$ & $<1.50 \mathrm{E}-02$ & $<6.00 \mathrm{E}-07$ & $<2.56 \mathrm{E}-05$ & $2.28 \mathrm{E}-04$ & $3-187993$ \\
\hline 3-187994 & 24 & $6.68 \mathrm{E}+02$ & $1.77 \mathrm{E}+01$ & 4.54E-03 & $<6.0 \mathrm{E}+01$ & $<1.50 \mathrm{E}-02$ & $<6.00 \mathrm{E}-07$ & $<2.56 \mathrm{E}-05$ & $2.92 \mathrm{E}-04$ & 3-187994 \\
\hline $3-187995$ & 26 & $5.56 \mathrm{E}+02$ & $1.47 \mathrm{E}+01$ & $3.78 \mathrm{E}-03$ & $<6.0 \mathrm{E}+01$ & $<1.50 \mathrm{E}-02$ & $<6.00 \mathrm{E}-07$ & $<2.56 \mathrm{E}-05$ & $2.88 \mathrm{E}-04$ & $3-187995$ \\
\hline
\end{tabular}

$\mathrm{nm}=$ not measured

na $=$ not applicable 
APPENDIX D5-1: LOADING CYCLE \#5

\section{Lead Column}

Resin: SuperLig ${ }^{\circledR} 639$

Resin Batch \# I-R2-03-27-02-20-45
Column size $=1.45 \mathrm{~cm}$

Flow rate $=3 \mathrm{BV} / \mathrm{h}(0.6 \mathrm{~mL} / \mathrm{min})$

$B V=12 \mathrm{~mL}$

\begin{tabular}{|c|c|c|c|c|c|c|c|c|}
\hline LIMS \# & BV & $\begin{array}{l}\text { [Tc-99], } \\
\text { dpm/mL }\end{array}$ & $\begin{array}{l}\text { [Tc-99], } \\
\mu \mathrm{Ci} / \mathrm{mL}\end{array}$ & {$[\mathrm{Tc}-99], \mu \mathrm{g} / \mathrm{L}$} & [Tc-99],C/Co & [Tc-99], M & {$[\mathbf{K}+], \mathbf{M}$} & {$[\mathbf{N a}+], \mathbf{M}$} \\
\hline $3-188867$ & 5 & $2.74 \mathrm{E}+02$ & $1.23 \mathrm{E}-04$ & $7.27 \mathrm{E}+00$ & $1.86 \mathrm{E}-03$ & $<1.00 \mathrm{E}-06$ & 0.33 & 4.01 \\
\hline $3-188868$ & 10 & $1.50 \mathrm{E}+02$ & $6.76 \mathrm{E}-05$ & $3.97 \mathrm{E}+00$ & $1.02 \mathrm{E}-03$ & $\mathrm{~nm}$ & 0.60 & 4.78 \\
\hline $3-188869$ & 20 & $1.70 \mathrm{E}+02$ & $7.66 \mathrm{E}-05$ & $4.51 \mathrm{E}+00$ & $1.16 \mathrm{E}-03$ & $\mathrm{~nm}$ & $\mathrm{~nm}$ & $\mathrm{~nm}$ \\
\hline $3-188870$ & 30 & $2.15 \mathrm{E}+02$ & $9.68 \mathrm{E}-05$ & $5.71 \mathrm{E}+00$ & $1.46 \mathrm{E}-03$ & $\mathrm{~nm}$ & $\mathrm{~nm}$ & $\mathrm{~nm}$ \\
\hline 3-188871 & 40 & $2.60 \mathrm{E}+02$ & $1.17 \mathrm{E}-04$ & $6.89 \mathrm{E}+00$ & $1.77 \mathrm{E}-03$ & $\mathrm{~nm}$ & $\mathrm{~nm}$ & $\mathrm{~nm}$ \\
\hline $3-188872$ & 50 & $2.73 \mathrm{E}+02$ & $1.23 \mathrm{E}-04$ & $7.23 \mathrm{E}+00$ & $1.86 \mathrm{E}-03$ & $<1.00 \mathrm{E}-06$ & 0.46 & 4.01 \\
\hline $3-188873$ & 60 & $3.34 \mathrm{E}+02$ & $1.50 \mathrm{E}-04$ & $8.84 \mathrm{E}+00$ & $2.27 \mathrm{E}-03$ & $\mathrm{~nm}$ & $\mathrm{~nm}$ & $\mathrm{~nm}$ \\
\hline $3-188874$ & 70 & $4.39 \mathrm{E}+02$ & $1.98 \mathrm{E}-04$ & $1.16 \mathrm{E}+01$ & 2.99E-03 & $\mathrm{nm}$ & $\mathrm{nm}$ & $\mathrm{nm}$ \\
\hline $3-188875$ & 80 & $5.97 \mathrm{E}+02$ & $2.69 \mathrm{E}-04$ & $1.58 \mathrm{E}+01$ & $4.06 \mathrm{E}-03$ & $\mathrm{~nm}$ & $\mathrm{~nm}$ & $\mathrm{~nm}$ \\
\hline $3-188876$ & 90 & $8.64 \mathrm{E}+02$ & $3.89 \mathrm{E}-04$ & $2.29 \mathrm{E}+01$ & $5.88 \mathrm{E}-03$ & $\mathrm{~nm}$ & $\mathrm{~nm}$ & $\mathrm{~nm}$ \\
\hline $3-188877$ & 100 & $1.18 \mathrm{E}+03$ & $5.32 \mathrm{E}-04$ & $3.13 \mathrm{E}+01$ & $8.03 \mathrm{E}-03$ & $<1.00 \mathrm{E}-06$ & 0.46 & 2.97 \\
\hline $3-188878$ & 110 & $1.55 \mathrm{E}+03$ & $6.98 \mathrm{E}-04$ & $4.11 \mathrm{E}+01$ & $1.05 \mathrm{E}-02$ & $\mathrm{~nm}$ & $\mathrm{~nm}$ & $\mathrm{~nm}$ \\
\hline $3-188879$ & 120 & $2.07 \mathrm{E}+03$ & $9.32 \mathrm{E}-04$ & $5.48 \mathrm{E}+01$ & $1.41 \mathrm{E}-02$ & $\mathrm{~nm}$ & $\mathrm{~nm}$ & $\mathrm{~nm}$ \\
\hline $3-188880$ & 130 & $2.46 \mathrm{E}+03$ & $1.11 \mathrm{E}-03$ & $6.51 \mathrm{E}+01$ & $1.67 \mathrm{E}-02$ & $\mathrm{~nm}$ & $\mathrm{~nm}$ & $\mathrm{~nm}$ \\
\hline 3-188881 & 140 & $3.18 \mathrm{E}+03$ & $1.43 \mathrm{E}-03$ & $8.43 \mathrm{E}+01$ & $2.16 \mathrm{E}-02$ & $\mathrm{~nm}$ & $\mathrm{~nm}$ & $\mathrm{~nm}$ \\
\hline $3-188882$ & 150 & $3.62 \mathrm{E}+03$ & $1.63 \mathrm{E}-03$ & $9.59 \mathrm{E}+01$ & $2.46 \mathrm{E}-02$ & $<1.00 \mathrm{E}-06$ & 0.50 & 4.10 \\
\hline 3-188883 & 160 & $4.56 \mathrm{E}+03$ & $2.05 \mathrm{E}-03$ & $1.21 \mathrm{E}+02$ & $3.10 \mathrm{E}-02$ & $\mathrm{~nm}$ & $\mathrm{~nm}$ & $\mathrm{~nm}$ \\
\hline 3-188884 & 170 & $5.22 \mathrm{E}+03$ & $2.35 \mathrm{E}-03$ & $1.38 \mathrm{E}+02$ & $3.55 \mathrm{E}-02$ & $\mathrm{~nm}$ & $\mathrm{~nm}$ & $\mathrm{~nm}$ \\
\hline $3-188885$ & 180 & $6.20 \mathrm{E}+03$ & $2.79 \mathrm{E}-03$ & $1.64 \mathrm{E}+02$ & $4.22 \mathrm{E}-02$ & $\mathrm{~nm}$ & $\mathrm{~nm}$ & $\mathrm{~nm}$ \\
\hline $3-188886$ & 190 & $6.85 \mathrm{E}+03$ & $3.09 \mathrm{E}-03$ & $1.81 \mathrm{E}+02$ & $4.66 \mathrm{E}-02$ & $\mathrm{~nm}$ & $\mathrm{~nm}$ & $\mathrm{~nm}$ \\
\hline 3-188887 & 200 & $7.80 \mathrm{E}+03$ & $3.51 \mathrm{E}-03$ & $2.07 \mathrm{E}+02$ & $5.31 \mathrm{E}-02$ & $<1.00 \mathrm{E}-06$ & 0.48 & 3.97 \\
\hline $3-188888$ & 210 & $8.90 \mathrm{E}+03$ & $4.01 \mathrm{E}-03$ & $2.36 \mathrm{E}+02$ & $6.05 \mathrm{E}-02$ & $\mathrm{~nm}$ & $\mathrm{~nm}$ & $\mathrm{~nm}$ \\
\hline 3-188889 & 220 & $1.03 \mathrm{E}+04$ & $4.64 \mathrm{E}-03$ & $2.72 \mathrm{E}+02$ & $7.01 \mathrm{E}-02$ & $\mathrm{~nm}$ & $\mathrm{~nm}$ & $\mathrm{~nm}$ \\
\hline $3-188890$ & 230 & $1.05 \mathrm{E}+04$ & $4.73 \mathrm{E}-03$ & $2.78 \mathrm{E}+02$ & $7.14 \mathrm{E}-02$ & $\mathrm{~nm}$ & $\mathrm{~nm}$ & $\mathrm{~nm}$ \\
\hline 3-188891 & 240 & $1.24 \mathrm{E}+04$ & $5.59 \mathrm{E}-03$ & $3.28 \mathrm{E}+02$ & $8.44 \mathrm{E}-02$ & $\mathrm{~nm}$ & $\mathrm{~nm}$ & $\mathrm{~nm}$ \\
\hline 3-188892 & 250 & $1.43 \mathrm{E}+04$ & $6.44 \mathrm{E}-03$ & $3.78 \mathrm{E}+02$ & $9.73 \mathrm{E}-02$ & $2.38 \mathrm{E}-06$ & 0.53 & 4.43 \\
\hline $3-188893$ & 260 & $1.64 \mathrm{E}+04$ & 7.39E-03 & $4.36 \mathrm{E}+02$ & $1.12 \mathrm{E}-01$ & $\mathrm{~nm}$ & $\mathrm{~nm}$ & $\mathrm{~nm}$ \\
\hline 3-188894 & 270 & $1.83 \mathrm{E}+04$ & $8.24 \mathrm{E}-03$ & $4.86 \mathrm{E}+02$ & $1.24 \mathrm{E}-01$ & $\mathrm{~nm}$ & $\mathrm{~nm}$ & $\mathrm{~nm}$ \\
\hline 3-188895 & 280 & $2.06 \mathrm{E}+04$ & $9.28 \mathrm{E}-03$ & $5.47 \mathrm{E}+02$ & $1.40 \mathrm{E}-01$ & $\mathrm{~nm}$ & $\mathrm{~nm}$ & $\mathrm{~nm}$ \\
\hline
\end{tabular}


APPENDIX D5-2: LOADING CYCLE \#5

Lag Column

Resin: SuperLig ${ }^{\circledR} 639$

Resin Batch \# I-R2-03-27-02-20-45

Column size $=1.45 \mathrm{~cm}$

Flow rate $=3 \mathrm{BV} / \mathrm{h}(0.6 \mathrm{~mL} / \mathrm{min})$

$B V=12 \mathrm{~mL}$

Composite Fractions - Lag Column

\begin{tabular}{|c|c|c|c|}
\hline LIMS \# & Effluent fraction \# & [Tc-99], dpm/mL & [Tc-99], ug/L \\
\hline $3-188912$ & bottle \# 1 - 20 BV & $4.26 \mathrm{E}+01$ & $1.13 \mathrm{E}+00$ \\
\hline $3-188913$ & bottle \# 2 - 20 BV & $8.96 \mathrm{E}+01$ & $2.38 \mathrm{E}+00$ \\
\hline $3-188914$ & bottle \# 3 - 20 BV & $8.66 \mathrm{E}+01$ & $2.29 \mathrm{E}+00$ \\
\hline $3-188915$ & bottle \# 4 - 20 BV & $8.14 \mathrm{E}+01$ & $2.16 \mathrm{E}+00$ \\
\hline $3-188916$ & bottle \# 5 - 20 BV & $1.05 \mathrm{E}+02$ & $2.78 \mathrm{E}+00$ \\
\hline $3-188917$ & bottle \# 6 - 20 BV & $4.20 \mathrm{E}+01$ & $2.11 \mathrm{E}+00$ \\
\hline $3-188918$ & bottle \# 7 - 20 BV & $9.34 \mathrm{E}+01$ & $3.26 \mathrm{E}+00$ \\
\hline $3-188919$ & bottle \# 8 - 20 BV & $1.23 \mathrm{E}+02$ & $\mathrm{~nm}$ \\
\hline $3-188920$ & bottle \# 9- 20 BV & $\mathrm{nm}$ & $\mathrm{nm}$ \\
\hline $3-188921$ & bottle \# 10 - 20 BV & $\mathrm{nm}$ & $\mathrm{nm}$ \\
\hline $3-188922$ & bottle \# 11- 20 BV & $\mathrm{nm}$ & \\
\hline
\end{tabular}

Individual Samples - Lag Column

\begin{tabular}{|c|c|c|c|c|}
\hline LIMS \# & BV & [Tc-99], dpm/mL & [Tc-99], $\mu \mathrm{g} / \mathrm{L}$ & $\mathrm{C} / \mathrm{Co}$ \\
\hline $3-188897$ & 20 & $3.90 \mathrm{E}+01$ & $1.03 \mathrm{E}+00$ & $2.65 \mathrm{E}-04$ \\
\hline $3-188898$ & 40 & $3.07 \mathrm{E}+01$ & $8.12 \mathrm{E}-01$ & $2.09 \mathrm{E}-04$ \\
\hline $3-188899$ & 60 & $5.36 \mathrm{E}+01$ & $1.42 \mathrm{E}+00$ & $3.65 \mathrm{E}-04$ \\
\hline $3-188900$ & 80 & $5.50 \mathrm{E}+01$ & $1.46 \mathrm{E}+00$ & $3.74 \mathrm{E}-04$ \\
\hline 3-188901 & 100 & $7.16 \mathrm{E}+01$ & $1.90 \mathrm{E}+00$ & 4.87E-04 \\
\hline 3-188902 & 120 & $5.25 \mathrm{E}+01$ & $1.39 \mathrm{E}+00$ & $3.57 \mathrm{E}-04$ \\
\hline $3-188903$ & 140 & $6.22 \mathrm{E}+01$ & $1.65 \mathrm{E}+00$ & $4.23 \mathrm{E}-04$ \\
\hline $3-188904$ & 160 & $3.54 \mathrm{E}+01$ & $9.39 \mathrm{E}-01$ & $2.41 \mathrm{E}-04$ \\
\hline 3-188905 & 180 & $3.65 \mathrm{E}+01$ & $9.68 \mathrm{E}-01$ & $2.48 \mathrm{E}-04$ \\
\hline 3-188906 & 200 & $4.28 \mathrm{E}+01$ & $1.14 \mathrm{E}+00$ & $2.91 \mathrm{E}-04$ \\
\hline $3-188907$ & 220 & $5.09 \mathrm{E}+01$ & $1.35 \mathrm{E}+00$ & $3.46 \mathrm{E}-04$ \\
\hline $3-188908$ & 240 & $9.08 \mathrm{E}+01$ & $2.41 \mathrm{E}+00$ & $6.18 \mathrm{E}-04$ \\
\hline 3-188909 & 260 & $1.36 \mathrm{E}+02$ & $3.59 \mathrm{E}+00$ & $9.25 \mathrm{E}-04$ \\
\hline $3-188910$ & 280 & $1.58 \mathrm{E}+02$ & $4.19 \mathrm{E}+00$ & $1.07 \mathrm{E}-03$ \\
\hline
\end{tabular}


APPENDIX D5-3: LOADING CYCLE \#5

\section{Lag Column}

Resin: SuperLig ${ }^{\circledR} 639$

Column size $=1.45 \mathrm{~cm}$

Resin Batch \# I-R2-03-27-02-20-45

Flow rate $=3 \mathrm{BV} / \mathrm{h}(0.6 \mathrm{~mL} / \mathrm{min})$

$\mathrm{BV}=12 \mathrm{~mL}$

Feed Displacement $-0.1 \mathrm{NaOH}$

\begin{tabular}{|c|c|c|c|c|c|c|c|c|c|}
\hline Sample & LIMS \# & BV & $\begin{array}{l}\text { [Tc-99], } \\
\text { dpm/mL }\end{array}$ & $\begin{array}{c}\text { [Tc-99], } \\
\text { C/Co }\end{array}$ & $\begin{array}{c}\text { [Tc-99], } \\
\mu \mathrm{g} / \mathrm{L}\end{array}$ & [Tc-99], M & {$[\mathbf{K}+], \mathbf{M}$} & {$[\mathbf{N a}+], \mathbf{M}$} & [NO3-], M \\
\hline wash-1 & $3-188923$ & 0.5 & $2.10 \mathrm{E}+04$ & $1.43 \mathrm{E}-01$ & $4.23 \mathrm{E}+02$ & 4.27E-06 & 5.77E-01 & $5.09 \mathrm{E}+00$ & $1.44 \mathrm{E}+00$ \\
\hline wash-2 & 3-188924 & 1 & $2.41 \mathrm{E}+04$ & $1.64 \mathrm{E}-01$ & $2.12 \mathrm{E}+02$ & $2.14 \mathrm{E}-06$ & $3.31 \mathrm{E}-01$ & $3.29 \mathrm{E}+00$ & $1.17 \mathrm{E}+00$ \\
\hline wash-3 & $3-188925$ & 1.5 & $1.91 \mathrm{E}+04$ & $1.30 \mathrm{E}-01$ & $3.98 \mathrm{E}+02$ & $4.02 \mathrm{E}-06$ & $1.45 \mathrm{E}-01$ & $1.62 \mathrm{E}+00$ & $1.49 \mathrm{E}+00$ \\
\hline wash-4 & 3-188926 & 2 & $1.39 \mathrm{E}+04$ & $9.46 \mathrm{E}-02$ & $2.21 \mathrm{E}+02$ & $2.23 \mathrm{E}-06$ & 8.36E-02 & $5.74 \mathrm{E}-01$ & $1.60 \mathrm{E}+00$ \\
\hline wash-6 & 3-188928 & 3 & $9.08 \mathrm{E}+03$ & $6.18 \mathrm{E}-02$ & $<1.92 \mathrm{E}+02$ & $<1.94 \mathrm{E}-06$ & $4.21 \mathrm{E}-02$ & $1.86 \mathrm{E}-01$ & $3.67 \mathrm{E}-01$ \\
\hline wash-7 & 3-188929 & 3.5 & $1.02 \mathrm{E}+04$ & $6.94 \mathrm{E}-02$ & $<2.40 \mathrm{E}+02$ & $<2.42 \mathrm{E}-06$ & $2.90 \mathrm{E}-02$ & $1.53 \mathrm{E}-01$ & $2.11 \mathrm{E}-01$ \\
\hline wash-8 & $3-188930$ & 4 & $2.60 \mathrm{E}+04$ & $1.77 \mathrm{E}-01$ & $<3.33 \mathrm{E}+02$ & $<3.36 \mathrm{E}-06$ & $2.06 \mathrm{E}-02$ & $1.36 \mathrm{E}-01$ & $1.49 \mathrm{E}-01$ \\
\hline
\end{tabular}




\section{APPENDIX D}

WSRC-TR-2003-00098, REVISION 0 SRT-RPP-2003-00026, REVISION 0

APPENDIX D5-4: LOADING CYCLE \#5

\section{Lead Column}

Eluant $=$ DI Water

Resin Batch \# I-R2-03-27-02-20-45

Column size $=1.45 \mathrm{~cm}$

Flow rate $=\sim 1 \mathrm{BV} / \mathrm{h}(\sim 0.2 \mathrm{~mL} / \mathrm{min}) ; \mathrm{BV}=12 \mathrm{~mL}$

Temperature $=65^{\circ} \mathrm{C}$

\begin{tabular}{|c|c|c|c|c|c|c|c|c|c|}
\hline LIMS \# & BV Eluate & $\begin{array}{l}\text { [Tc-99], } \\
\text { dpm/mL }\end{array}$ & $\begin{array}{c}{[\text { Tc-99], }} \\
\mu \mathrm{g} / \mathrm{L}\end{array}$ & $\begin{array}{c}\text { [Tc-99], } \\
\text { C/Co }\end{array}$ & $\begin{array}{c}\text { [Tc-99] } \\
\mu \mathrm{g} / \mathrm{L}\end{array}$ & $\begin{array}{c}\text { [Tc-99], } \\
\text { C/Co }\end{array}$ & [Tc-99], M & {$\left[\mathrm{K}^{+}\right], \mathbf{M}$} & {$\left[\mathrm{Na}^{+}\right], \mathrm{M}$} \\
\hline 3-188931 & 0.5 & $3.86 \mathrm{E}+05$ & $1.02 \mathrm{E}+04$ & $2.63 \mathrm{E}+00$ & $7.77 \mathrm{E}+03$ & $1.94 \mathrm{E}+00$ & $7.85 \mathrm{E}-05$ & $1.78 \mathrm{E}-02$ & $1.03 \mathrm{E}-01$ \\
\hline 3-188932 & 1 & $1.19 \mathrm{E}+06$ & $3.16 \mathrm{E}+04$ & $8.10 \mathrm{E}+00$ & $2.51 \mathrm{E}+04$ & $6.27 \mathrm{E}+00$ & $2.54 \mathrm{E}-04$ & $9.18 \mathrm{E}-03$ & $6.78 \mathrm{E}-02$ \\
\hline 3-188933 & 1.5 & $1.66 \mathrm{E}+06$ & $4.41 \mathrm{E}+04$ & $1.13 \mathrm{E}+01$ & $3.61 \mathrm{E}+04$ & $9.02 \mathrm{E}+00$ & $3.65 \mathrm{E}-04$ & $6.31 \mathrm{E}-03$ & $2.96 \mathrm{E}-02$ \\
\hline 3-188934 & 2 & $2.63 \mathrm{E}+06$ & $6.97 \mathrm{E}+04$ & $1.79 \mathrm{E}+01$ & $5.51 \mathrm{E}+04$ & $1.38 \mathrm{E}+01$ & $5.56 \mathrm{E}-04$ & $5.23 \mathrm{E}-03$ & $1.05 \mathrm{E}-02$ \\
\hline $3-188935$ & 2.5 & $8.29 \mathrm{E}+06$ & $2.20 \mathrm{E}+05$ & $5.64 \mathrm{E}+01$ & $1.91 \mathrm{E}+05$ & $4.77 \mathrm{E}+01$ & $1.93 \mathrm{E}-03$ & $3.31 \mathrm{E}-03$ & 5.35E-03 \\
\hline 3-188936 & 3 & $1.13 \mathrm{E}+07$ & $2.99 \mathrm{E}+05$ & $7.69 \mathrm{E}+01$ & $2.65 \mathrm{E}+05$ & $6.61 \mathrm{E}+01$ & $2.67 \mathrm{E}-03$ & $1.88 \mathrm{E}-03$ & $3.07 \mathrm{E}-03$ \\
\hline 3-188937 & 3.5 & $1.01 \mathrm{E}+07$ & $2.67 \mathrm{E}+05$ & $6.87 \mathrm{E}+01$ & $2.35 \mathrm{E}+05$ & $5.87 \mathrm{E}+01$ & $2.37 \mathrm{E}-03$ & $2.36 \mathrm{E}-03$ & $1.91 \mathrm{E}-03$ \\
\hline $3-188938$ & 4 & $9.87 \mathrm{E}+06$ & $2.61 \mathrm{E}+05$ & $6.71 \mathrm{E}+01$ & $2.27 \mathrm{E}+05$ & $5.67 \mathrm{E}+01$ & $2.29 \mathrm{E}-03$ & $3.31 \mathrm{E}-03$ & $1.36 \mathrm{E}-03$ \\
\hline 3-188939 & 6 & $6.66 \mathrm{E}+06$ & $1.77 \mathrm{E}+05$ & $4.53 \mathrm{E}+01$ & $1.50 \mathrm{E}+05$ & $3.75 \mathrm{E}+01$ & $1.52 \mathrm{E}-03$ & $2.11 \mathrm{E}-03$ & $1.17 \mathrm{E}-03$ \\
\hline 3-188940 & 8 & $1.42 \mathrm{E}+06$ & $3.75 \mathrm{E}+04$ & $9.66 \mathrm{E}+00$ & $3.10 \mathrm{E}+04$ & $7.75 \mathrm{E}+00$ & $3.13 \mathrm{E}-04$ & $9.26 \mathrm{E}-04$ & 8.83E-04 \\
\hline 3-188941 & 10 & $4.68 \mathrm{E}+04$ & $1.24 \mathrm{E}+03$ & $3.18 \mathrm{E}-01$ & $9.12 \mathrm{E}+02$ & $2.28 \mathrm{E}-01$ & $9.21 \mathrm{E}-06$ & $4.05 \mathrm{E}-04$ & $6.91 \mathrm{E}-04$ \\
\hline 3-188942 & 12 & $7.46 \mathrm{E}+03$ & $1.98 \mathrm{E}+02$ & $5.07 \mathrm{E}-02$ & $8.10 \mathrm{E}+01$ & $2.02 \mathrm{E}-02$ & $8.18 \mathrm{E}-07$ & $<3.85$ E-04 & $6.57 \mathrm{E}-04$ \\
\hline 3-188943 & 14 & $2.78 \mathrm{E}+03$ & $7.37 \mathrm{E}+01$ & $1.89 \mathrm{E}-02$ & $<9.6 \mathrm{E}+01$ & $<2.40 \mathrm{E}-02$ & $<9.70 \mathrm{E}-07$ & $<3.85 \mathrm{E}-04$ & $8.30 \mathrm{E}-04$ \\
\hline 3-188944 & 16 & $1.52 \mathrm{E}+03$ & $4.02 \mathrm{E}+01$ & $1.03 \mathrm{E}-02$ & $<9.6 \mathrm{E}+01$ & $<2.40 \mathrm{E}-02$ & $<9.70 \mathrm{E}-07$ & $<3.85 \mathrm{E}-04$ & $7.13 \mathrm{E}-04$ \\
\hline 3-188945 & 18 & $1.11 \mathrm{E}+03$ & $2.94 \mathrm{E}+01$ & $7.55 \mathrm{E}-03$ & $<9.6 \mathrm{E}+01$ & $<2.40 \mathrm{E}-02$ & $<9.70 \mathrm{E}-07$ & $<3.85$ E-04 & $6.52 \mathrm{E}-04$ \\
\hline 3-188946 & 20 & $2.78 \mathrm{E}+03$ & $7.36 \mathrm{E}+01$ & $1.89 \mathrm{E}-02$ & $<9.6 \mathrm{E}+01$ & $<2.40 \mathrm{E}-02$ & $<9.70 \mathrm{E}-07$ & $<3.85 \mathrm{E}-04$ & $6.26 \mathrm{E}-04$ \\
\hline 3-188947 & 22 & $7.82 \mathrm{E}+02$ & $2.07 \mathrm{E}+01$ & $5.32 \mathrm{E}-03$ & $<1.2 \mathrm{E}+02$ & $<3.00 \mathrm{E}-02$ & $<1.21 \mathrm{E}-06$ & $<4.82 \mathrm{E}-04$ & $8.22 \mathrm{E}-04$ \\
\hline $3-188948$ & 24 & $6.88 \mathrm{E}+02$ & $1.82 \mathrm{E}+01$ & $4.68 \mathrm{E}-03$ & $<1.2 \mathrm{E}+02$ & $<3.00 \mathrm{E}-02$ & $<1.21 \mathrm{E}-06$ & $<4.82 \mathrm{E}-04$ & $5.30 \mathrm{E}-04$ \\
\hline 3-188949 & 26 & $6.75 \mathrm{E}+02$ & $1.79 \mathrm{E}+01$ & $4.59 \mathrm{E}-03$ & $<1.2 \mathrm{E}+02$ & $<3.00 \mathrm{E}-02$ & $<1.21 \mathrm{E}-06$ & $<4.82 \mathrm{E}-04$ & $8.17 \mathrm{E}-04$ \\
\hline $3-188950$ & 27 & $6.00 \mathrm{E}+02$ & $1.59 \mathrm{E}+01$ & $4.08 \mathrm{E}-03$ & $<1.2 \mathrm{E}+02$ & $<3.00 \mathrm{E}-02$ & $<1.21 \mathrm{E}-06$ & $<4.82 \mathrm{E}-04$ & $6.96 \mathrm{E}-04$ \\
\hline 3-188952 & 30 & $5.34 \mathrm{E}+02$ & $1.41 \mathrm{E}+01$ & $3.63 \mathrm{E}-03$ & $<1.2 \mathrm{E}+02$ & $<3.00 \mathrm{E}-02$ & $<1.21 \mathrm{E}-06$ & $<4.82 \mathrm{E}-04$ & 5.43E-04 \\
\hline
\end{tabular}




\section{APPENDIX E - COMPOSITE PRODUCTS DATA}

\section{APPENDIX E1 - EFFLUENT COMPOSITE PRODUCTS}

\begin{tabular}{|c|c|c|c|c|c|c|c|c|c|c|}
\hline Analyte & cycle -1 & cycle -1D & cycle -2 & cycle $-2 D$ & cycle -3 & cycle -3D & cycle -4 & cycle $-4 D$ & cycle -5 & cycle $-5 D$ \\
\hline LIMS \# & $3-188182$ & $3-188183$ & $3-188184$ & 3-188185 & 3-188186 & 3-188187 & 3-190142 & $3-190143$ & 3-190138 & 3-190139 \\
\hline $\mathrm{C}-137, \mu \mathrm{Ci} / \mathrm{mL}$ & $3.73 \mathrm{E}-04$ & $3.23 \mathrm{E}-04$ & $3.70 \mathrm{E}-03$ & $3.73 \mathrm{E}-03$ & $2.83 \mathrm{E}-03$ & $2.91 \mathrm{E}-03$ & $4.49 \mathrm{E}-03$ & $4.52 \mathrm{E}-03$ & $6.11 \mathrm{E}-01$ & $6.07 \mathrm{E}-01$ \\
\hline Tc-99, $\mu \mathrm{Ci} / \mathrm{mL}$ & $4.82 \mathrm{E}-05$ & $2.49 \mathrm{E}-05$ & $5.59 \mathrm{E}-05$ & $6.31 \mathrm{E}-05$ & $3.73 \mathrm{E}-05$ & $4.68 \mathrm{E}-05$ & $3.31 \mathrm{E}-05$ & $4.16 \mathrm{E}-05$ & $3.78 \mathrm{E}-05$ & $2.10 \mathrm{E}-05$ \\
\hline $\begin{array}{l}\text { Tc-99, } \mu \mathrm{g} / \mathrm{L} \\
\text { (ICP-MS) }\end{array}$ & 205 & 242 & 170 & 193 & 201 & 196 & 132 & 137 & 124 & 127 \\
\hline $\begin{array}{l}\mathrm{U}-238, \mu \mathrm{g} / \mathrm{L} \\
\text { (ICP-MS) }\end{array}$ & 24.9 & $<\mathrm{DTL}$ & $<\mathrm{DTL}$ & 55.6 & 5.96 & $<\mathrm{DTL}$ & $\mathrm{nm}$ & $\mathrm{nm}$ & $\mathrm{nm}$ & $\mathrm{nm}$ \\
\hline $\begin{array}{l}\text { Total carbon, } \\
\mathrm{mg} / \mathrm{L}\end{array}$ & 3120 & 2280 & 2860 & 2600 & 2230 & 2640 & 11600 & 20700 & 7560 & 23800 \\
\hline $\mathrm{TIC}, \mathrm{mg} / \mathrm{L}$ & 1070 & 840 & 1130 & 1070 & & 983 & 9610 & 20500 & 5430 & 22800 \\
\hline $\mathrm{TOC}, \mathrm{mg} / \mathrm{L}$ & 2050 & 1440 & 1730 & 1530 & 22230 & 1657 & 1990 & 200 & 2130 & 1000 \\
\hline Total base, $\mathrm{M}$ & 2.79 & 2.78 & 2.84 & 2.82 & 2.79 & 2.78 & 2.93 & 2.83 & 2.85 & 2.81 \\
\hline Free $\mathrm{OH}^{-}, \mathrm{M}$ & 2.07 & 2.03 & 2.03 & 1.99 & 1.81 & 1.86 & 2.1 & 2.1 & 2.1 & 2.07 \\
\hline $\begin{array}{l}\text { wt. \% dissolved } \\
\text { solids }\end{array}$ & 31.557 & 31.4187 & 32.3644 & 32.1323 & 32.3107 & 32.3923 & $\mathrm{~nm}$ & $\mathrm{~nm}$ & $\mathrm{~nm}$ & $\mathrm{~nm}$ \\
\hline specific gravity & 1.23 & 1.23 & 1.23 & 1.23 & 1.23 & 1.23 & 1.23 & 1.23 & 1.23 & 1.23 \\
\hline IC (anions), $\mathrm{M}$ & $3-188188$ & $3-188189$ & $3-188190$ & 3-188191 & 3-188192 & $3-188193$ & 3-190144 & 3-190145 & $3-190140$ & 3-190141 \\
\hline $\mathrm{Cl}-$ & $6.15 \mathrm{E}-02$ & $6.29 \mathrm{E}-02$ & $6.09 \mathrm{E}-02$ & $6.60 \mathrm{E}-02$ & $5.87 \mathrm{E}-02$ & $6.49 \mathrm{E}-02$ & $6.60 \mathrm{E}-02$ & $6.60 \mathrm{E}-02$ & $6.46 \mathrm{E}-02$ & $6.46 \mathrm{E}-02$ \\
\hline F- & $9.69 \mathrm{E}-03$ & $9.58 \mathrm{E}-03$ & $6.64 \mathrm{E}-03$ & $7.21 \mathrm{E}-03$ & $6.16 \mathrm{E}-03$ & $7.58 \mathrm{E}-03$ & $1.05 \mathrm{E}-03$ & $1.05 \mathrm{E}-03$ & $4.90 \mathrm{E}-03$ & $1.05 \mathrm{E}-03$ \\
\hline HCOO- & $7.36 \mathrm{E}-03$ & $1.88 \mathrm{E}-02$ & $6.11 \mathrm{E}-03$ & $7.38 \mathrm{E}-03$ & $6.04 \mathrm{E}-03$ & $8.13 \mathrm{E}-03$ & $1.15 \mathrm{E}-02$ & $1.14 \mathrm{E}-02$ & $1.14 \mathrm{E}-02$ & $1.17 \mathrm{E}-02$ \\
\hline NO3- & $1.37 \mathrm{E}+00$ & $1.32 \mathrm{E}+00$ & $1.16 \mathrm{E}+00$ & $1.40 \mathrm{E}+00$ & $1.09 \mathrm{E}+00$ & $1.35 \mathrm{E}+00$ & $1.32 \mathrm{E}+00$ & $1.31 \mathrm{E}+00$ & $1.18 \mathrm{E}+00$ & $1.31 \mathrm{E}+00$ \\
\hline NO2- & $8.85 \mathrm{E}-01$ & $9.09 \mathrm{E}-01$ & $8.72 \mathrm{E}-01$ & $9.52 \mathrm{E}-01$ & $8.52 \mathrm{E}-01$ & $9.37 \mathrm{E}-01$ & $9.26 \mathrm{E}-01$ & $9.28 \mathrm{E}-01$ & $9.22 \mathrm{E}-01$ & $9.28 \mathrm{E}-01$ \\
\hline $\mathrm{H}(\mathrm{COO}) 2-$ & $2.04 \mathrm{E}-03$ & $2.12 \mathrm{E}-03$ & $1.89 \mathrm{E}-03$ & $1.93 \mathrm{E}-03$ & $1.73 \mathrm{E}-03$ & $1.91 \mathrm{E}-03$ & $1.93 \mathrm{E}-03$ & $1.87 \mathrm{E}-03$ & $2.30 \mathrm{E}-03$ & $1.92 \mathrm{E}-03$ \\
\hline PO4- & $2.34 \mathrm{E}-03$ & $2.50 \mathrm{E}-03$ & $2.12 \mathrm{E}-03$ & $1.81 \mathrm{E}-03$ & $2.19 \mathrm{E}-03$ & $1.90 \mathrm{E}-03$ & $2.27 \mathrm{E}-03$ & $2.48 \mathrm{E}-03$ & $2.62 \mathrm{E}-03$ & $2.84 \mathrm{E}-03$ \\
\hline SO4- & $1.63 \mathrm{E}-03$ & $1.68 \mathrm{E}-03$ & $1.39 \mathrm{E}-03$ & $1.34 \mathrm{E}-03$ & $1.68 \mathrm{E}-03$ & $1.26 \mathrm{E}-03$ & $1.21 \mathrm{E}-03$ & $1.13 \mathrm{E}-03$ & $1.41 \mathrm{E}-03$ & $1.45 \mathrm{E}-03$ \\
\hline
\end{tabular}


APPENDIX E1 - EFFLUENT COMPOSITE PRODUCTS - continued

\begin{tabular}{|c|c|c|c|c|c|c|c|c|c|c|}
\hline Analyte & cycle -1 & cycle -1D & cycle -2 & cycle -2D & cycle -3 & cycle -3D & cycle -4 & cycle $-4 D$ & cycle -5 & cycle $-5 D$ \\
\hline \multicolumn{11}{|l|}{ ICP-ES, mg/L } \\
\hline $\mathrm{Ag}$ & 0.357 & 0.356 & 0.389 & 0.369 & 0.412 & 0.411 & 0.314 & 0.282 & 0.279 & 0.387 \\
\hline $\mathrm{Al}$ & 13600 & 13700 & 13900 & 14100 & 14000 & 14000 & 11700 & 11200 & 12000 & 11400 \\
\hline $\mathrm{B}$ & 18.5 & 18.5 & 18.9 & 19.2 & 18.8 & 19.0 & 17.9 & 15.6 & 16.8 & 17.6 \\
\hline $\mathrm{Ba}$ & 0.542 & 0.533 & 0.588 & 0.576 & 0.588 & 0.572 & $<0.380$ & $<0.380$ & $<0.380$ & $<0.380$ \\
\hline $\mathrm{Ca}$ & 5.95 & 5.95 & 6.22 & 6.21 & 6.20 & 6.25 & 5.06 & 4.93 & 5.56 & 5.03 \\
\hline $\mathrm{Cd}$ & 0.987 & 0.976 & 1.05 & 1.08 & 1.03 & 1.03 & 0.833 & 0.735 & 0.839 & 0.801 \\
\hline $\mathrm{Ce}$ & 4.16 & 4.18 & 4.48 & 4.35 & 4.78 & 4.73 & 3.98 & 3.78 & 3.68 & 4.73 \\
\hline $\mathrm{Cr}$ & 37.1 & 37.4 & 43.4 & 42.9 & 41.5 & 41.7 & 36.6 & 34.2 & 37.3 & 36.2 \\
\hline $\mathrm{Cu}$ & 3.74 & 3.82 & 2.46 & 2.54 & 2.62 & 2.67 & 1.67 & 1.51 & 1.21 & 1.19 \\
\hline $\mathrm{Fe}$ & 1.45 & 1.44 & 1.77 & 1.77 & 1.79 & 1.80 & 1.64 & 1.52 & 1.91 & 1.81 \\
\hline $\mathrm{Gd}$ & $<0.468$ & $<0.468$ & 0.468 & $<0.468$ & 0.510 & 0.510 & $<0.468$ & $<0.468$ & $<0.468$ & 0.517 \\
\hline $\mathrm{K}$ & 21200 & 21400 & 22000 & 21800 & 21700 & 21800 & 17800 & 17100 & 18400 & 16900 \\
\hline $\mathrm{La}$ & 0.777 & 0.772 & 0.814 & 0.770 & 0.866 & 0.841 & 0.590 & 0.577 & 0.553 & 0.666 \\
\hline $\mathrm{Li}$ & $<0.860$ & $<0.860$ & $<0.860$ & $<0.860$ & $<0.860$ & 1.10 & 0.887 & $<0.860$ & $<0.860$ & 1.06 \\
\hline $\mathrm{Mg}$ & $<0.106$ & $<0.106$ & $<0.106$ & $<0.106$ & $<0.106$ & $<0.106$ & $<0.106$ & $<0.106$ & $<0.106$ & $<0.106$ \\
\hline $\mathrm{Mn}$ & $<0.016$ & $<0.016$ & $<0.016$ & $<0.016$ & $<0.016$ & $<0.016$ & $<0.016$ & $<0.016$ & $<0.016$ & $<0.016$ \\
\hline Mo & 43.1 & 42.2 & 43.7 & 43.5 & 44.4 & 43.3 & 35.5 & 33.8 & 35.3 & 35.4 \\
\hline $\mathrm{Na}$ & 116000 & 116000 & 119000 & 122000 & 120000 & 120000 & 103000 & 98700 & 106000 & 101000 \\
\hline $\mathrm{Ni}$ & 2.52 & 2.40 & 2.53 & 2.53 & 2.24 & 2.46 & 2.32 & 2.06 & 2.22 & 2.09 \\
\hline $\mathrm{P}$ & 145 & 146 & 150 & 148 & 149 & 149 & 134 & 126 & 138 & 133 \\
\hline $\mathrm{Pb}$ & 15.1 & 14.9 & 16.4 & 15.9 & 15.1 & 16.0 & 13.6 & 12.4 & 14.3 & 13.3 \\
\hline $\mathrm{Sb}$ & 39.3 & 39.5 & 40.7 & 40.6 & 41.3 & 40.4 & 31.7 & 30.0 & 32.8 & 31.5 \\
\hline $\mathrm{Si}$ & 91.5 & 91.5 & 91.7 & 87.5 & 89.6 & 90.2 & 70.0 & 64.6 & 69.5 & 67.7 \\
\hline $\mathrm{Sn}$ & 76.0 & 77.9 & 80.0 & 78.1 & 78.7 & 79.0 & 62.1 & 58.3 & 62.3 & 60.8 \\
\hline $\mathrm{Sr}$ & 2.00 & 1.99 & 2.05 & 2.08 & 2.05 & 2.10 & 1.64 & 1.54 & 1.84 & 1.77 \\
\hline Tc & $<0.060$ & $<0.060$ & $<0.060$ & $<0.060$ & $<0.060$ & $<0.060$ & $<0.060$ & $<0.060$ & $<0.060$ & $<0.060$ \\
\hline Tc & $<0.180$ & $<0.180$ & $<0.180$ & $<0.180$ & $<0.180$ & $<0.180$ & $<0.180$ & $<0.180$ & $<0.180$ & $<0.180$ \\
\hline $\mathrm{Ti}$ & $<0.154$ & $<0.154$ & $<0.154$ & $<0.154$ & $<0.154$ & $<0.154$ & $<0.154$ & $<0.154$ & $<0.154$ & $<0.154$ \\
\hline $\mathrm{U}$ & $<4.54$ & $<4.54$ & $<4.54$ & $<4.54$ & $<4.54$ & $<4.54$ & $<4.54$ & $<4.54$ & $<4.54$ & $<4.54$ \\
\hline $\mathrm{Zn}$ & 4.60 & 4.56 & 4.69 & 4.69 & 4.75 & 4.95 & 4.16 & 3.79 & 4.12 & 4.03 \\
\hline $\mathrm{Zr}$ & 4.41 & 4.46 & 6.06 & 6.05 & 5.45 & 5.43 & 5.07 & 4.83 & 5.38 & 5.10 \\
\hline
\end{tabular}


APPENDIX E2 - CESIUM ELUATE - COMPOSITE PRODUCTS

\begin{tabular}{|c|c|c|c|c|c|c|c|c|c|c|c|c|}
\hline Analyte & cycle -1 & cycle -1D & cycle -2 & cycle -2D & cycle $\mathbf{- 3}$ & cycle -3D & cycle -4 & cycle $-4 D$ & cycle -5 & cycle -5D & cycle -6 & cycle $-6 D$ \\
\hline $\begin{array}{l}\mathrm{C}-137, \\
\mu \mathrm{Ci} / \mathrm{mL}\end{array}$ & $1.89 \mathrm{E}+03$ & $1.69 \mathrm{E}+03$ & $2.28 \mathrm{E}+03$ & $2.22 \mathrm{E}+03$ & $2.12 \mathrm{E}+03$ & $2.11 \mathrm{E}+03$ & $1.72 \mathrm{E}+03$ & $3.08 \mathrm{E}+03$ & $1.64 \mathrm{E}+03$ & $1.64 \mathrm{E}+03$ & $9.90 \mathrm{E}+02$ & $8.36 \mathrm{E}+02$ \\
\hline $\begin{array}{l}\text { Tc-99, } \\
\mu \mathrm{Ci} / \mathrm{mL}\end{array}$ & $1.68 \mathrm{E}-03$ & $? ? ?$ & $1.83 \mathrm{E}-03$ & 4.19E-03 & $4.18 \mathrm{E}-03$ & $2.11 \mathrm{E}-03$ & $1.96 \mathrm{E}-03$ & $1.04 \mathrm{E}-02$ & $1.48 \mathrm{E}-03$ & $1.98 \mathrm{E}-03$ & $2.26 \mathrm{E}-03$ & $2.40 \mathrm{E}-03$ \\
\hline $\begin{array}{l}\text { Tc-99, } \mu \mathrm{g} / \mathrm{L} \\
\text { (ICP-MS) }\end{array}$ & $2.38 \mathrm{E}+02$ & $2.20 \mathrm{E}+02$ & $2.96 \mathrm{E}+02$ & $2.54 \mathrm{E}+02$ & $2.61 \mathrm{E}+02$ & $2.12 \mathrm{E}+02$ & $2.16 \mathrm{E}+02$ & $3.83 \mathrm{E}+02$ & $2.09 \mathrm{E}+02$ & $2.11 \mathrm{E}+02$ & $\mathrm{~nm}$ & $\mathrm{~nm}$ \\
\hline $\begin{array}{l}\mathrm{U}-238, \mu \mathrm{g} / \mathrm{L} \\
\text { (ICP-MS) }\end{array}$ & 70 & 63 & 82 & 71 & 86 & 76 & 172 & 154 & 68 & 63 & $\mathrm{~nm}$ & $\mathrm{~nm}$ \\
\hline $\begin{array}{l}\text { Total carbon, } \\
\mathrm{mg} / \mathrm{L}\end{array}$ & $2.09 \mathrm{E}+03$ & $1.07 \mathrm{E}+03$ & $1.09 \mathrm{E}+03$ & $1.46 \mathrm{E}+03$ & $1.27 \mathrm{E}+03$ & $6.51 \mathrm{E}+03$ & $1.32 \mathrm{E}+03$ & $1.13 \mathrm{E}+03$ & $9.04 \mathrm{E}+02$ & $7.15 \mathrm{E}+02$ & $\mathrm{~nm}$ & $\mathrm{~nm}$ \\
\hline TIC, mg/L & $<\mathrm{DTL}$ & $<$ DTL & $<\mathrm{DTL}$ & $<\mathrm{DTL}$ & $<\mathrm{DTL}$ & $3.87 \mathrm{E}+03$ & $<\mathrm{DTL}$ & $<\mathrm{DTL}$ & $<\mathrm{DTL}$ & $<$ DTL & $\mathrm{nm}$ & $\mathrm{nm}$ \\
\hline $\mathrm{TOC}, \mathrm{mg} / \mathrm{L}$ & $2.09 \mathrm{E}+03$ & $1.07 \mathrm{E}+03$ & $1.09 \mathrm{E}+03$ & $1.46 \mathrm{E}+03$ & $1.27 \mathrm{E}+03$ & $2.64 \mathrm{E}+03$ & $1.32 \mathrm{E}+03$ & $1.13 \mathrm{E}+03$ & $9.04 \mathrm{E}+02$ & $7.15 \mathrm{E}+02$ & $\mathrm{~nm}$ & $\mathrm{~nm}$ \\
\hline IC (anions), M & & & & & & & & & & & $\mathrm{nm}$ & $\mathrm{nm}$ \\
\hline $\mathrm{Cl}-$ & $1.55 \mathrm{E}-02$ & $1.47 \mathrm{E}-02$ & $1.46 \mathrm{E}-02$ & $1.68 \mathrm{E}-02$ & $1.55 \mathrm{E}-02$ & $1.55 \mathrm{E}-02$ & $1.52 \mathrm{E}-02$ & $1.37 \mathrm{E}-02$ & $1.46 \mathrm{E}-02$ & $1.52 \mathrm{E}-02$ & $1.51 \mathrm{E}-02$ & $1.65 \mathrm{E}-02$ \\
\hline F- & $2.90 \mathrm{E}-02$ & $2.75 \mathrm{E}-02$ & $2.73 \mathrm{E}-02$ & $3.13 \mathrm{E}-02$ & $2.89 \mathrm{E}-02$ & $2.90 \mathrm{E}-02$ & $2.83 \mathrm{E}-02$ & $2.55 \mathrm{E}-02$ & $2.73 \mathrm{E}-02$ & $2.84 \mathrm{E}-02$ & $2.82 \mathrm{E}-02$ & 3.07E-02 \\
\hline HCOO- & $6.11 \mathrm{E}-02$ & $5.80 \mathrm{E}-02$ & $5.76 \mathrm{E}-02$ & $6.61 \mathrm{E}-02$ & $6.10 \mathrm{E}-02$ & $6.12 \mathrm{E}-02$ & $5.98 \mathrm{E}-02$ & $5.38 \mathrm{E}-02$ & $5.75 \mathrm{E}-02$ & $6.00 \mathrm{E}-02$ & $5.94 \mathrm{E}-02$ & $6.48 \mathrm{E}-02$ \\
\hline NO3- & $2.94 \mathrm{E}+04$ & $2.77 \mathrm{E}+04$ & $2.82 \mathrm{E}+04$ & $2.65 \mathrm{E}+04$ & $4.37 \mathrm{E}+04$ & $5.73 E+04$ & $3.34 \mathrm{E}+04$ & $4.70 \mathrm{E}+04$ & $2.87 \mathrm{E}+04$ & $3.00 \mathrm{E}+04$ & $\mathrm{~nm}$ & $\mathrm{~nm}$ \\
\hline NO2- & $5.98 \mathrm{E}-02$ & $5.68 \mathrm{E}-02$ & $5.63 \mathrm{E}-02$ & $6.46 \mathrm{E}-02$ & $5.97 \mathrm{E}-02$ & 5.99E-02 & $5.85 \mathrm{E}-02$ & $5.27 \mathrm{E}-02$ & $5.63 \mathrm{E}-02$ & $5.87 \mathrm{E}-02$ & $5.81 \mathrm{E}-02$ & 6.34E-02 \\
\hline $\mathrm{H}(\mathrm{COO}) 2-$ & $3.09 \mathrm{E}-02$ & $2.93 \mathrm{E}-02$ & $2.91 \mathrm{E}-02$ & $3.34 \mathrm{E}-02$ & $3.08 \mathrm{E}-02$ & $3.09 \mathrm{E}-02$ & $3.02 \mathrm{E}-02$ & $2.72 \mathrm{E}-02$ & $2.91 \mathrm{E}-02$ & $3.03 \mathrm{E}-02$ & $3.00 \mathrm{E}-02$ & $3.28 \mathrm{E}-02$ \\
\hline PO4- & $2.90 \mathrm{E}-02$ & $2.75 \mathrm{E}-02$ & $2.73 \mathrm{E}-02$ & $3.13 \mathrm{E}-02$ & $2.89 \mathrm{E}-02$ & $2.90 \mathrm{E}-02$ & $2.83 \mathrm{E}-02$ & $2.55 \mathrm{E}-02$ & $2.73 \mathrm{E}-02$ & $2.84 \mathrm{E}-02$ & $2.81 \mathrm{E}-02$ & $3.07 \mathrm{E}-02$ \\
\hline SO4- & $1.43 \mathrm{E}-02$ & $1.36 \mathrm{E}-02$ & $1.35 \mathrm{E}-02$ & $1.55 \mathrm{E}-02$ & $1.43 \mathrm{E}-02$ & $1.43 \mathrm{E}-02$ & $1.40 \mathrm{E}-02$ & $1.26 \mathrm{E}-02$ & $1.35 \mathrm{E}-02$ & $1.41 \mathrm{E}-02$ & 1.39E-02 & $1.52 \mathrm{E}-02$ \\
\hline $\begin{array}{l}\text { Dilution } \\
\text { factors }\end{array}$ & 275 & 261 & 259 & 297 & 275 & 275 & 269 & 242 & 259 & 270 & 267 & 292 \\
\hline
\end{tabular}


APPENDIX E2 - CESIUM ELUATE - COMPOSITE PRODUCTS - continued

\begin{tabular}{|c|c|c|c|c|c|c|c|c|c|c|c|c|}
\hline Analyte & cycle -1 & cycle $-1 D$ & cycle -2 & cycle $-2 D$ & cycle -3 & cycle -3D & cycle -4 & cycle $-4 D$ & cycle -5 & cycle $-5 D$ & cycle -6 & cycle $-6 \mathrm{D}$ \\
\hline ICP-ES, mg/L & & & & & & & & & & & $\mathrm{nm}$ & $\mathrm{nm}$ \\
\hline $\mathrm{Ag}$ & $<0.160$ & $<0.160$ & $<0.160$ & $<0.160$ & $<0.160$ & $<0.160$ & $<0.160$ & $<0.160$ & $<0.160$ & $<0.160$ & $\mathrm{~nm}$ & $\mathrm{~nm}$ \\
\hline $\mathrm{Al}$ & $<1.14$ & $<1.14$ & $<1.14$ & $<1.14$ & $<1.14$ & $<1.14$ & $<1.14$ & $<1.14$ & $<1.14$ & $<1.14$ & $\mathrm{~nm}$ & $\mathrm{~nm}$ \\
\hline $\mathrm{B}$ & $7.18 \mathrm{E}+02$ & $6.71 \mathrm{E}+02$ & $6.35 \mathrm{E}+02$ & $7.58 \mathrm{E}+02$ & $8.10 \mathrm{E}+02$ & $3.28 \mathrm{E}+02$ & $6.40 \mathrm{E}+02$ & $6.83 \mathrm{E}+02$ & $7.46 \mathrm{E}+02$ & $6.86 \mathrm{E}+02$ & $\mathrm{~nm}$ & $\mathrm{~nm}$ \\
\hline $\mathrm{Ba}$ & $<0.380$ & $<0.380$ & $<0.380$ & $<0.380$ & $<0.380$ & $<0.380$ & $<0.380$ & $<0.380$ & $<0.380$ & $<0.380$ & $\mathrm{~nm}$ & $\mathrm{~nm}$ \\
\hline $\mathrm{Ca}$ & $<0.460$ & $<0.460$ & $<0.460$ & $<0.460$ & $<0.460$ & $<0.460$ & $<0.460$ & $<0.460$ & $<0.460$ & $<0.460$ & $\mathrm{~nm}$ & $\mathrm{~nm}$ \\
\hline $\mathrm{Cd}$ & $<0.084$ & $<0.084$ & $<0.084$ & $<0.084$ & $<0.084$ & $<0.084$ & $<0.084$ & $<0.084$ & $<0.084$ & $<0.084$ & $\mathrm{~nm}$ & $\mathrm{~nm}$ \\
\hline $\mathrm{Ce}$ & $3.22 \mathrm{E}+02$ & $3.00 \mathrm{E}+02$ & $3.39 \mathrm{E}+02$ & $3.98 \mathrm{E}+02$ & $2.91 \mathrm{E}+02$ & $3.47 \mathrm{E}+02$ & $3.07 \mathrm{E}+02$ & $2.45 \mathrm{E}+02$ & $2.80 \mathrm{E}+02$ & $3.00 \mathrm{E}+02$ & $\mathrm{~nm}$ & $\mathrm{~nm}$ \\
\hline $\mathrm{Cr}$ & $<0.120$ & $<0.120$ & $<0.120$ & $<0.120$ & $<0.120$ & $<0.120$ & $<0.120$ & $<0.120$ & $<0.120$ & $<0.120$ & $\mathrm{~nm}$ & $\mathrm{~nm}$ \\
\hline $\mathrm{Cu}$ & $1.55 \mathrm{E}+02$ & $1.46 \mathrm{E}+02$ & $1.48 \mathrm{E}+02$ & $1.71 \mathrm{E}+02$ & $1.45 \mathrm{E}+02$ & $1.56 \mathrm{E}+02$ & $1.49 \mathrm{E}+02$ & $1.38 \mathrm{E}+02$ & $1.44 \mathrm{E}+02$ & $1.49 \mathrm{E}+02$ & $\mathrm{~nm}$ & $\mathrm{~nm}$ \\
\hline $\mathrm{Fe}$ & $<0.072$ & $<0.072$ & $<0.072$ & $<0.072$ & $<0.072$ & $<0.072$ & $<0.072$ & $<0.072$ & $<0.072$ & $<0.072$ & $\mathrm{~nm}$ & $\mathrm{~nm}$ \\
\hline $\mathrm{Gd}$ & $<0.468$ & $<0.468$ & $<0.468$ & $<0.468$ & $<0.468$ & $<0.468$ & $<0.468$ & $<0.468$ & $<0.468$ & $<0.468$ & $\mathrm{~nm}$ & $\mathrm{~nm}$ \\
\hline $\mathrm{K}$ & $<18.8$ & $<18.8$ & $<18.8$ & $<18.8$ & $<18.8$ & 21.4 & $<18.8$ & $<18.8$ & $<18.8$ & $<18.8$ & $\mathrm{~nm}$ & $\mathrm{~nm}$ \\
\hline $\mathrm{La}$ & $4.45 \mathrm{E}+01$ & $5.59 \mathrm{E}+01$ & $5.93 \mathrm{E}+01$ & $6.21 \mathrm{E}+01$ & $5.08 \mathrm{E}+01$ & $5.70 \mathrm{E}+01$ & $4.39 \mathrm{E}+01$ & $4.17 \mathrm{E}+01$ & $4.17 \mathrm{E}+01$ & $5.29 \mathrm{E}+01$ & $\mathrm{~nm}$ & $\mathrm{~nm}$ \\
\hline $\mathrm{Li}$ & $<0.860$ & $<0.860$ & $<0.860$ & $<0.860$ & $<0.860$ & $<0.860$ & $<0.860$ & $<0.860$ & $<0.860$ & $<0.860$ & $\mathrm{~nm}$ & $\mathrm{~nm}$ \\
\hline $\mathrm{Mg}$ & $<0.106$ & $<0.106$ & $<0.106$ & $<0.106$ & $<0.106$ & $<0.106$ & $<0.106$ & $<0.106$ & $<0.106$ & $<0.106$ & $\mathrm{~nm}$ & $\mathrm{~nm}$ \\
\hline $\mathrm{Mn}$ & $<0.016$ & $<0.016$ & $<0.016$ & $<0.016$ & $<0.016$ & $<0.016$ & $<0.016$ & $<0.016$ & $<0.016$ & $<0.016$ & $\mathrm{~nm}$ & $\mathrm{~nm}$ \\
\hline Mo & $<1.06$ & $<1.06$ & $<1.06$ & $<1.06$ & $<1.06$ & $<1.06$ & $<1.06$ & $<1.06$ & $<1.06$ & $<1.06$ & $\mathrm{~nm}$ & $\mathrm{~nm}$ \\
\hline $\mathrm{Na}$ & $1.68 \mathrm{E}+03$ & $1.58 \mathrm{E}+03$ & $1.92 \mathrm{E}+03$ & $2.07 \mathrm{E}+03$ & $1.44 \mathrm{E}+04$ & $3.61 \mathrm{E}+04$ & $1.58 \mathrm{E}+03$ & $2.42 \mathrm{E}+03$ & $1.65 \mathrm{E}+03$ & $1.51 \mathrm{E}+03$ & $\mathrm{~nm}$ & $\mathrm{~nm}$ \\
\hline $\mathrm{Ni}$ & $<0.270$ & $<0.270$ & $<0.270$ & $<0.270$ & $<0.270$ & $<0.270$ & $<0.270$ & $<0.270$ & $<0.270$ & $<0.270$ & $\mathrm{~nm}$ & $\mathrm{~nm}$ \\
\hline $\mathrm{P}$ & $<1.38$ & $<1.38$ & $<1.38$ & $<1.38$ & $<1.38$ & $<1.38$ & $<1.38$ & $<1.38$ & $<1.38$ & $<1.38$ & $\mathrm{~nm}$ & $\mathrm{~nm}$ \\
\hline $\mathrm{Pb}$ & $<0.638$ & $<0.638$ & $<0.638$ & $<0.638$ & $<0.638$ & $<0.638$ & $<0.638$ & $<0.638$ & $<0.638$ & $<0.638$ & $\mathrm{~nm}$ & $\mathrm{~nm}$ \\
\hline $\mathrm{Sb}$ & $<7.56$ & $<7.56$ & $<7.56$ & $<7.56$ & $<7.56$ & $<7.56$ & $<7.56$ & $<7.56$ & $<7.56$ & $<7.56$ & $\mathrm{~nm}$ & $\mathrm{~nm}$ \\
\hline $\mathrm{Si}$ & $<0.334$ & $<0.334$ & $<0.334$ & $<0.334$ & $<0.334$ & $<0.334$ & $<0.334$ & $<0.334$ & $<0.334$ & $<0.334$ & $\mathrm{~nm}$ & $\mathrm{~nm}$ \\
\hline $\mathrm{Sn}$ & $3.16 \mathrm{E}+02$ & $3.66 \mathrm{E}+02$ & $3.78 \mathrm{E}+02$ & $5.41 \mathrm{E}+02$ & $3.46 \mathrm{E}+02$ & $3.83 \mathrm{E}+02$ & $4.65 \mathrm{E}+02$ & $3.34 \mathrm{E}+02$ & $3.73 \mathrm{E}+02$ & $3.51 \mathrm{E}+02$ & $\mathrm{~nm}$ & $\mathrm{~nm}$ \\
\hline $\mathrm{Sr}$ & $<0.152$ & $<0.152$ & $<0.152$ & $<0.152$ & $<0.152$ & $<0.152$ & $<0.152$ & $<0.152$ & $<0.152$ & $<0.152$ & $\mathrm{~nm}$ & $\mathrm{~nm}$ \\
\hline $\mathrm{Tc}$ & $<0.060$ & $<0.060$ & $<0.060$ & $<0.060$ & $<0.060$ & $<0.060$ & $<0.060$ & $<0.060$ & $<0.060$ & $<0.060$ & $\mathrm{~nm}$ & $\mathrm{~nm}$ \\
\hline $\mathrm{Tc}$ & $<0.180$ & $<0.180$ & $<0.180$ & $<0.180$ & $<0.180$ & $<0.180$ & $<0.180$ & $<0.180$ & $<0.180$ & $<0.180$ & $\mathrm{~nm}$ & $\mathrm{~nm}$ \\
\hline $\mathrm{Ti}$ & $<0.154$ & $<0.154$ & $<0.154$ & $<0.154$ & $<0.154$ & $<0.154$ & $<0.154$ & $<0.154$ & $<0.154$ & $<0.154$ & $\mathrm{~nm}$ & $\mathrm{~nm}$ \\
\hline $\mathrm{U}$ & $<4.54$ & $<4.54$ & $<4.54$ & $<4.54$ & $<4.54$ & $<4.54$ & $<4.54$ & $<4.54$ & $<4.54$ & $<4.54$ & $\mathrm{~nm}$ & $\mathrm{~nm}$ \\
\hline $\mathrm{Zn}$ & $<0.064$ & $<0.064$ & $<0.064$ & $<0.064$ & $<0.064$ & $<0.064$ & $<0.064$ & $<0.064$ & $<0.064$ & $<0.064$ & $\mathrm{~nm}$ & $\mathrm{~nm}$ \\
\hline $\mathrm{Zr}$ & $<0.456$ & $<0.456$ & $<0.456$ & $<0.456$ & $<0.456$ & $<0.456$ & $<0.456$ & $<0.456$ & $<0.456$ & $<0.456$ & $\mathrm{~nm}$ & $\mathrm{~nm}$ \\
\hline
\end{tabular}




\section{APPENDIX E}

WSRC-TR-2003-00098, REVISION 0 SRT-RPP-2003-00026, REVISION 0

APPENDIX E3 - TECHNICIUM ELUATE - COMPOSITE PRODUCTS

\begin{tabular}{|c|c|c|c|c|c|c|c|c|c|c|}
\hline Analyte & cycle -1 & cycle -1D & cycle -2 & cycle $-2 D$ & cycle -3 & cycle -3D & cycle -4 & cycle -4D & cycle -5 & cycle $-5 D$ \\
\hline${ }^{137} \mathrm{Cs}, \mu \mathrm{Ci} / \mathrm{mL}$ & $7.93 \mathrm{E}-05$ & $8.68 \mathrm{E}-05$ & $2.89 \mathrm{E}-04$ & $2.66 \mathrm{E}-04$ & $1.06 \mathrm{E}-02$ & $2.70 \mathrm{E}-03$ & $2.51 \mathrm{E}-04$ & $2.30 \mathrm{E}-04$ & $1.64 \mathrm{E}-02$ & $1.61 \mathrm{E}-02$ \\
\hline${ }^{99} \mathrm{Tc}, \mu \mathrm{Ci} / \mathrm{mL}$ & $2.48 \mathrm{E}-01$ & $2.44 \mathrm{E}-01$ & $3.81 \mathrm{E}-01$ & $3.87 \mathrm{E}-01$ & $3.66 \mathrm{E}-01$ & $3.62 \mathrm{E}-01$ & $3.93 \mathrm{E}-01$ & $3.87 \mathrm{E}-01$ & $4.95 \mathrm{E}-01$ & $4.82 \mathrm{E}-01$ \\
\hline${ }^{99} \mathrm{Tc}, \mu \mathrm{g} / \mathrm{mL}$ & $1.45 \mathrm{E}+04$ & $1.48 \mathrm{E}+04$ & $2.08 \mathrm{E}+04$ & $2.13 \mathrm{E}+04$ & $2.03 \mathrm{E}+04$ & $2.06 \mathrm{E}+04$ & $2.12 \mathrm{E}+04$ & $2.29 \mathrm{E}+04$ & $\mathrm{~nm}$ & $\mathrm{~nm}$ \\
\hline${ }^{238} \mathrm{U}, \mu \mathrm{g} / \mathrm{mL}$ & 4.5 & 2.7 & 7.4 & 10.2 & 9.5 & 37.3 & 16.2 & 41.9 & $\mathrm{~nm}$ & $\mathrm{~nm}$ \\
\hline \multicolumn{11}{|l|}{ IC (anions), M } \\
\hline $\mathrm{Cl}-$ & $<5.64 \mathrm{E}-05$ & $<5.64 \mathrm{E}-05$ & $3.33 \mathrm{E}-03$ & $3.33 \mathrm{E}-03$ & $1.69 \mathrm{E}-04$ & $1.69 \mathrm{E}-04$ & $1.13 \mathrm{E}-04$ & 9.59E-04 & $\mathrm{nm}$ & $\mathrm{nm}$ \\
\hline F- & $<1.05 \mathrm{E}-04$ & $<1.05 \mathrm{E}-04$ & $2.63 \mathrm{E}-04$ & 2.63E-04 & $<1.05 \mathrm{E}-04$ & $<1.05 \mathrm{E}-04$ & $<1.05 \mathrm{E}-04$ & $<1.05 \mathrm{E}-04$ & $\mathrm{~nm}$ & $\mathrm{~nm}$ \\
\hline HCOO- & $<2.22 \mathrm{E}-04$ & $<2.22 \mathrm{E}-04$ & $1.07 \mathrm{E}-03$ & $1.09 \mathrm{E}-03$ & $<2.22 \mathrm{E}-04$ & $<2.22 \mathrm{E}-04$ & $<2.22 \mathrm{E}-04$ & $<2.22 \mathrm{E}-04$ & $\mathrm{~nm}$ & $\mathrm{~nm}$ \\
\hline NO3- & $3.39 \mathrm{E}-04$ & 3.39E-04 & $8.81 \mathrm{E}-02$ & $8.65 \mathrm{E}-02$ & 4.34E-03 & 4.32E-03 & $3.16 \mathrm{E}-03$ & $3.19 \mathrm{E}-03$ & $\mathrm{~nm}$ & $\mathrm{~nm}$ \\
\hline NO2- & $1.74 \mathrm{E}-04$ & $1.96 \mathrm{E}-04$ & $4.46 \mathrm{E}-02$ & $4.37 \mathrm{E}-02$ & $3.22 \mathrm{E}-03$ & $3.17 \mathrm{E}-03$ & $2.37 \mathrm{E}-03$ & 2.39E-03 & $\mathrm{nm}$ & $\mathrm{nm}$ \\
\hline$(\mathrm{C} 2 \mathrm{O} 4) 2-$ & $<1.14 \mathrm{E}-04$ & $<1.14 \mathrm{E}-04$ & $1.02 \mathrm{E}-04$ & $1.02 \mathrm{E}-04$ & $<1.14 \mathrm{E}-04$ & $<1.14 \mathrm{E}-04$ & $<1.14 \mathrm{E}-04$ & $<1.14 \mathrm{E}-04$ & $\mathrm{~nm}$ & $\mathrm{~nm}$ \\
\hline PO4- & $<1.05 \mathrm{E}-04$ & $<1.05 \mathrm{E}-04$ & $9.48 \mathrm{E}-05$ & $8.42 \mathrm{E}-05$ & $<1.05 \mathrm{E}-04$ & $<1.05 \mathrm{E}-04$ & $<1.05 \mathrm{E}-04$ & $<1.05 \mathrm{E}-04$ & $\mathrm{~nm}$ & $\mathrm{~nm}$ \\
\hline SO4- & $<5.21 \mathrm{E}-04$ & $<5.21 \mathrm{E}-04$ & $6.25 \mathrm{E}-05$ & $6.25 \mathrm{E}-05$ & $<5.21 \mathrm{E}-04$ & $<5.21 \mathrm{E}-04$ & $<5.21 \mathrm{E}-04$ & $<5.21 \mathrm{E}-04$ & $\mathrm{~nm}$ & $\mathrm{~nm}$ \\
\hline
\end{tabular}

$\mathrm{nm}=$ not measured 
APPENDIX E3 - TECHNICIUM ELUATE - COMPOSITE PRODUCTS - continued

\begin{tabular}{|c|c|c|c|c|c|c|c|c|c|c|}
\hline Analyte & cycle -1 & cycle -1D & cycle -2 & cycle -2D & cycle -3 & cycle -3D & cycle -4 & cycle $-4 D$ & cycle -5 & cycle $-5 D$ \\
\hline \multicolumn{11}{|l|}{ ICP-ES, mg/L } \\
\hline $\mathrm{Ag}$ & $<0.160$ & $<0.160$ & 0.164 & $<0.160$ & $<0.160$ & $<0.160$ & $<0.160$ & $<0.200$ & $<0.160$ & $<0.160$ \\
\hline $\mathrm{Al}$ & 2.20 & 1.78 & 612 & 616 & 45.2 & 45.6 & 31.1 & 30.6 & 34.0 & 33.9 \\
\hline $\mathrm{B}$ & 6.37 & 7.39 & 3.25 & 4.36 & 4.60 & 4.41 & 5.37 & 6.36 & 1.87 & 2.19 \\
\hline $\mathrm{Ba}$ & $<0.380$ & $<0.380$ & $<0.380$ & $<0.380$ & $<0.380$ & $<0.380$ & $<0.380$ & $<0.475$ & $<0.380$ & $<0.380$ \\
\hline $\mathrm{Be}$ & $<0.020$ & $<0.020$ & 0.062 & 0.072 & 0.047 & 0.023 & $<0.020$ & 0.040 & 0.055 & 0.049 \\
\hline $\mathrm{Ca}$ & $<0.460$ & $<0.460$ & $<0.460$ & $<0.460$ & $<0.460$ & $<0.460$ & $<0.460$ & $<0.575$ & $<0.460$ & $<0.460$ \\
\hline $\mathrm{Cd}$ & $<0.084$ & $<0.084$ & $<0.084$ & $<0.084$ & $<0.084$ & $<0.084$ & $<0.084$ & $<0.105$ & $<0.084$ & $<0.084$ \\
\hline $\mathrm{Ce}$ & 1.06 & 0.930 & 1.62 & 1.59 & 1.36 & 1.13 & 0.888 & 1.04 & $<0.540$ & $<0.540$ \\
\hline $\mathrm{Cr}$ & $<0.120$ & $<0.120$ & 1.85 & 1.83 & $<0.120$ & $<0.120$ & $<0.120$ & $<0.150$ & $<0.120$ & $<0.120$ \\
\hline $\mathrm{Cu}$ & 0.257 & 0.245 & 0.299 & 0.296 & 0.242 & 0.237 & 0.233 & 0.293 & 0.318 & 0.320 \\
\hline $\mathrm{Fe}$ & 0.457 & 0.401 & 0.526 & 0.391 & 0.237 & 0.178 & 0.209 & 0.164 & $<0.072$ & $<0.072$ \\
\hline $\mathrm{K}$ & 38.7 & 25.4 & 1220 & 1220 & 98.0 & 95.1 & 86.0 & 77.9 & 105 & 98.7 \\
\hline $\mathrm{La}$ & $<0.144$ & $<0.144$ & 0.221 & 0.220 & 0.185 & 0.150 & $<0.144$ & $<0.180$ & $<0.144$ & $<0.144$ \\
\hline $\mathrm{Li}$ & $<0.860$ & $<0.860$ & $<0.860$ & $<0.860$ & $<0.860$ & $<0.860$ & $<0.860$ & $<1.08$ & $<0.860$ & $<0.860$ \\
\hline $\mathrm{Mg}$ & $<0.106$ & $<0.106$ & $<0.106$ & $<0.106$ & $<0.106$ & $<0.106$ & $<0.106$ & $<0.133$ & $<0.106$ & $<0.106$ \\
\hline $\mathrm{Mn}$ & $<0.016$ & $<0.016$ & $<0.016$ & $<0.016$ & $<0.016$ & $<0.016$ & $<0.016$ & $<0.020$ & $<0.016$ & $<0.016$ \\
\hline Mo & $<1.06$ & $<1.06$ & 2.27 & 2.31 & $<1.06$ & $<1.06$ & $<1.06$ & $<1.33$ & $<1.06$ & $<1.06$ \\
\hline $\mathrm{Na}$ & 88.2 & 89.8 & 5800 & 5740 & 459 & 462 & 362 & 366 & 416 & 416 \\
\hline $\mathrm{Ni}$ & $<0.270$ & $<0.270$ & $<0.270$ & $<0.270$ & $<0.270$ & $<0.270$ & $<0.270$ & $<0.338$ & $<0.270$ & $<0.270$ \\
\hline $\mathrm{P}$ & 5.60 & 5.59 & 14.2 & 12.9 & 6.61 & 6.20 & 6.62 & 5.99 & $<1.38$ & $<1.38$ \\
\hline $\mathrm{Pb}$ & $<0.638$ & $<0.638$ & 0.724 & $<0.638$ & $<0.638$ & $<0.638$ & $<0.638$ & $<0.798$ & $<0.638$ & $<0.638$ \\
\hline $\mathrm{S}$ & $<2.74$ & $<2.74$ & 11.2 & 11.3 & $<2.74$ & $<2.74$ & $<2.74$ & $<3.43$ & $<2.74$ & $<2.74$ \\
\hline $\mathrm{Sb}$ & $<7.56$ & $<7.56$ & $<7.56$ & $<7.56$ & $<7.56$ & $<7.56$ & $<7.56$ & $<9.45$ & $<7.56$ & $<7.56$ \\
\hline $\mathrm{Si}$ & 9.67 & 12.1 & 16.5 & 19.0 & 7.13 & 8.28 & 4.84 & 7.29 & 4.60 & 4.93 \\
\hline $\mathrm{Sn}$ & $<0.900$ & $<0.900$ & 4.06 & 3.95 & $<0.900$ & 1.11 & $<0.900$ & $<1.13$ & $<0.900$ & $<0.900$ \\
\hline $\mathrm{Sr}$ & $<0.152$ & $<0.152$ & $<0.152$ & $<0.152$ & $<0.152$ & $<0.152$ & $<0.152$ & $<0.190$ & $<0.152$ & $<0.152$ \\
\hline $\mathrm{Ti}$ & $<0.154$ & $<0.154$ & $<0.154$ & $<0.154$ & $<0.154$ & $<0.154$ & $<0.154$ & $<0.193$ & $<0.154$ & $<0.154$ \\
\hline $\mathrm{U}$ & $<4.54$ & $<4.54$ & $<4.54$ & $<4.54$ & $<4.54$ & $<4.54$ & $<4.54$ & $<5.68$ & $<4.54$ & $<4.54$ \\
\hline $\mathrm{Zn}$ & $<0.064$ & $<0.064$ & 0.204 & 0.207 & $<0.064$ & $<0.064$ & $<0.064$ & $<0.080$ & $<0.064$ & $<0.064$ \\
\hline $\mathrm{Zr}$ & $<0.456$ & $<0.456$ & $<0.456$ & $<0.456$ & $<0.456$ & $<0.456$ & $<0.456$ & $<0.570$ & $<0.456$ & $<0.456$ \\
\hline
\end{tabular}

$\mathrm{nm}=$ not measured 


\section{APPENDIX F - DOSE CALCULATIONS FOR CS-137 LOADINGS OF ION EXCHANGE COLUMNS}

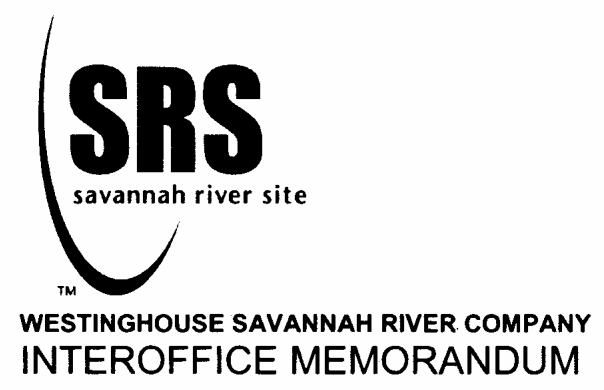

June 9,2003

SRT-ADS-2003-0325

TO: $\quad$ Neguib Hassan, 773-A

FROM: $\quad$ Frank Moore, 773A (5-5622)

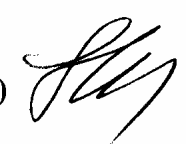

DOSE CALCULATIONS FOR CS-137 LOADINGS OF ION EXCHANGE COLUMNS

Ref: (1) SRT-ADS-2002-0207, F.S. Moore to Neguib Hassan, Dose Rate Calculations for Cesium Ion Exchange Column, April 25, 2002

(2) SRT-ADS-2003-0131, F.S. Moore to Neguib Hassan, Dose Rate Calculations for Cs137 Loadings of Ion Exchange Columns, March 18,2003

At your request, I have calculated the beta and gamma ray doses to the ion exchange medium during loadings with Cs-137. The following assumptions are used in the analysis:

(1) Cs-137 concentration is 175 microCuries $/ \mathrm{ml}$.

(2) The loading rate in column volumes/hr is given in column 5 of table 1.

(3) All of the Cs-137 is retained on the medium.

(4) The Cs-137 is uniformly distributed throughout the medium.

The ion exchange column is $1.45 \mathrm{~cm}$ in diameter, and has a volume of $15 \mathrm{ml}$. This analysis is identical to that reported in reference 2 for revised column volumes loaded and flow rates. Only one case, loading of the entire column volume, is considered here. As discussed in reference 1, beta decay provides the majority of the radiation dose. This is because the beta particles have a very short range and deposit all their energy in a small volume around the point at which the decay takes place.

Table 1 gives, for each run, the number of column volumes run through the column, the $\mathrm{Ci}$ of Cs-137 loaded in each run, the flow rate in column volumes/hr, and the time to load the column. From Appendix 1 of the referenced memo, the integrated dose received by the ion exchange medium is:

$\mathrm{D}_{\text {ose }}=\left(/ \mathrm{Dr}_{\max } / 2 \mathrm{~T}\right) * \mathrm{t}^{2}$,

Where $\mathrm{T}$ is the total time to load the column, and $\mathrm{t}$ is the time after loading started at which the information is desired, and $\mathrm{Dr}_{\text {mas }}$ is the dose rate to the medium when loading has been 
SRT-ADS-2003-0325

June 9, 2003

Page 2 of 2 .

completed. This may be obtained from table two of the referenced memo as follows: $\operatorname{Dr}_{\max }=($ (Dr-table 2)*(Ci loaded)/ 4.8; where 4.8 is the number of Ci loaded in the referenced memo. For example: for the first case: $\operatorname{Dr}_{\max }=(1.89 \mathrm{e} 4)^{*}(.50) / 4.8$. The time $t$ used for the dose to the column is the time at which loading is completed.

Table 2 gives the results of these calculations. The fifth column, "Dose to resin" gives the resulting dose if each of the 6 runs uses a separate column. If the same resin is used for more than one run, the Cs- 137 being eluted from the resin between runs, the total dose to the resin will be additive. This value is given in the sixth column "Total Dose to resin" assuming one column is used for all 6 runs. The doses are given in Roentgens (R).

Table 1

\begin{tabular}{rrrrrr}
\multicolumn{7}{c}{ Cs-137 loaded to column during run } & $15 \mathrm{ml}$ column \\
run no & $\begin{array}{r}\text { Cs-137 } \\
\mathrm{uCi} / \mathrm{ml}\end{array}$ & $\begin{array}{r}\text { col vol } \\
\text { loaded }\end{array}$ & $\begin{array}{c}\text { Ci loaded } \\
\text { per run }\end{array}$ & $\begin{array}{c}\text { flow rate } \\
\text { cv/hr }\end{array}$ & $\begin{array}{c}\text { Time to load } \\
\text { hours }\end{array}$ \\
1 & 175 & 190 & 0.50 & 0.69 & 275.36 \\
2 & 175 & 225 & 0.59 & 0.59 & 381.36 \\
3 & 175 & 193 & 0.51 & 0.52 & 371.15 \\
4 & 175 & 179 & 0.47 & 0.49 & 365.31 \\
5 & 175 & 172 & 0.45 & 0.49 & 351.02 \\
6 & 175 & 186 & 0.49 & 0.52 & 357.69
\end{tabular}

Table 2

$\begin{array}{rrrrrr}\begin{array}{c}\text { run } \\ \text { number }\end{array} & \begin{array}{r}\mathrm{Ci} \\ \text { added }\end{array} & \begin{array}{c}\text { max } \\ \text { dose rate } \\ \text { R/hr }\end{array} & \begin{array}{c}\text { run time } \\ \text { hours }\end{array} & \begin{array}{c}\text { Dose to } \\ \text { Resin } \\ \text { in run } \\ R\end{array} & \begin{array}{c}\text { Total } \\ \text { Dose to } \\ \text { Resin } \\ \text { R }\end{array} \\ 1 & 0.5 & 1.89 \mathrm{E}+04 & 275.36 & 2.60 \mathrm{E}+06 & 2.60 \mathrm{E}+06 \\ 2 & 0.59 & 2.22 \mathrm{E}+04 & 381.36 & 4.24 \mathrm{E}+06 & 6.84 \mathrm{E}+06 \\ 3 & 0.51 & 1.92 \mathrm{E}+04 & 371.15 & 3.57 \mathrm{E}+06 & 1.04 \mathrm{E}+07 \\ 4 & 0.47 & 1.77 \mathrm{E}+04 & 365.31 & 3.24 \mathrm{E}+06 & 1.36 \mathrm{E}+07 \\ 5 & 0.45 & 1.70 \mathrm{E}+04 & 351.02 & 2.98 \mathrm{E}+06 & 1.66 \mathrm{E}+07 \\ 6 & 0.49 & 1.85 \mathrm{E}+04 & 357.69 & 3.30 \mathrm{E}+06 & 1.99 \mathrm{E}+07\end{array}$

c: Saleem Salaymeh 773-41A 